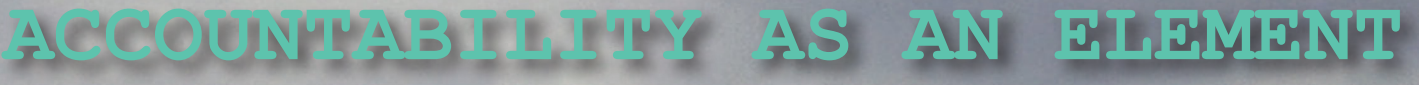

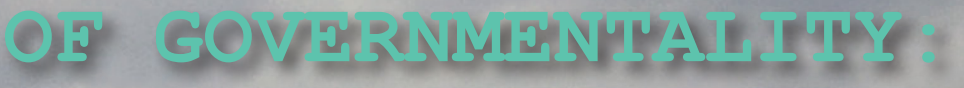

AN INVESTIGATION OF NATIONAL AND LOCAL EXECUTIVE ACCOUNTABILITY PRACTICES IN THE WATER SECTOR IN TANZANIA 
ACCOUNTABILITY AS AN ELEMENT OF GOVERNMENTALITY:

AN INVESTIGATION OF NATIONAL AND LOCAL EXECUTIVE

ACCOUNTABILITY PRACTICES IN THE WATER SECTOR IN TANZANIA

Jesper George Katomero 


\section{Graduation Committee:}

Chair:

Secretary:

Supervisor:

Co-supervisors:

Committee Members:
Prof. dr. T.A.J. Toonen, University of Twente Prof. dr. T.A.J. Toonen, University of Twente Prof. dr. R. Hoppe, University of Twente Dr. A. Pelizza, University of Twente Dr. A. Wesselink, Delft University of Technology

Prof. dr. S. Kuhlmann, University of Twente Prof. dr. J.T.A. Bressers, University of Twente Prof. dr. M.A.P. Bovens, University of Utrecht Prof. dr. P. van der Zaag, Delft University of Technology Dr. B. Bana, University of Dar es Salaam

\section{NWO \\ Netherlands Organisation for Scientific Research}

The funding for this thesis was provided by the Netherlands Organisation for Scientific Research for Global Development (NOW-WOTRO).

The thesis was printed with financial support from the Department of Science, Technology and Policy Studies (STePS) of the University of Twente.

Copyright (C) Jesper George Katomero, 2017 Enschede, the Netherlands.

Cover design: Proefschriftmaken, Enschede, the Netherlands

Cover image: Jesper George Katomero

Printing: Proefschriftmaken, Enschede, the Netherlands

ISBN: 978-90-365-4358-3

DOI: $10.3990 / 1.9789036543583$

URL: https://doi.org/10.3990/1.9789036543583 
ACCOUNTABILITY AS AN ELEMENT OF GOVERNMENTALITY:

AN INVESTIGATION OF NATIONAL AND LOCAL EXECUTIVE

ACCOUNTABILITY PRACTICES IN THE WATER SECTOR IN TANZANIA

\section{DISSERTATION}

to obtain

the degree of doctor at the University of Twente, on the authority of the rector magnificus, prof.dr. T.T.M. Palstra, on account of the decision of the graduation committee, to be publicly defended

on Friday, the $2^{\text {nd }}$ of June, 2017 at $12: 45 \mathrm{pm}$

by

\section{Jesper George Katomero}

born on June, 21.1981

in Kigoma, Tanzania 
This dissertation has been approved by:

Supervisor:

Co-supervisors:
Prof.dr. Robert Hoppe, University of Twente Dr. Anna Wesselink, Delft University of Technology

Dr. Annalisa Pelizza, University of Twente 


\section{Preface}

My PhD project was an incredible learning journey filled with intellectual challenges, social challenges, and great enthusiasm as well. As I arrived to the Netherlands on 20th May, 2012, I became fascinated with everything. As I stepped from the plane and walked into the arrival gates, everything looked impressive. The airport buildings, the airport staff, shopping centers, the entire organization - as I exit the airport to various transport channels, i.e. trains, buses, taxes, bicycles etcetera. - was indeed state of the art. This seemingly efficient planning of the airport and other connected infrastructure, and its accurate execution by the Dutch government enabled me to arrive at my final destination, the University of Twente, in Enschede comfortably and on time. As I travelled from Amsterdam to Enschede by train, the beautiful green fields, farms, trenches of water, wind mills, and dykes across the rail way tracks stretching thousands of kilometers were captivating and made my travel enjoyable and refreshing.

Such enthusiasm travelled with me to the university student hotel. I was impressed by the services offered at the student hotel. In particular, the water services were readily available throughout my stay in the Netherlands. There was never a time I could hear a pipe is vandalized, broken, dilapidated without timely replacement or unavailability of water services because of corruption, triggering a cause for concern. This is not to say that there are no challenges in the Dutch water sector. Non-the less, during my arrival at the hotel, I asked where I could get drinking water. To my surprise, a hotel attendant told me that: "sir you can get your drinking water from your bathroom tap; it is safe and clean for drinking". The response from the hotel worker struck me, because I had come from a country where access to safe and clean water is quite a challenge. Drinking water from a tap is 'suicidal'; you have to boil and cool it before drinking. In addition, water services are highly politicized, and access to it has not been improving despite significant government and donor investments.

This experience took me back to my early child hood. Growing up as a young boy in Kigoma, a remote region in the western part of Tanzania, I did not experience any water problems. Every day we had access to pipe-borne water at home. However, this changed when I was enrolled in a boarding secondary school, in the1990s, in the neighbouring region of Tabora located about $400 \mathrm{~km}$ east. There was no pipe-borne water in our school. At times, we travelled long distances to fetch water, especially during the dry season. During the rainy season, drinking water was 'brown coloured' and there was no bottled water at the time. There was no water treatment technology either. There were several cases of water-borne diseases afflicting students. The impact was felt by many students who could not take exams, who postponed studies etcetera.

When I moved to Dar es Salaam, there was no any difference. Previously, I had imagined Dar es Salaam as a big city with high quality social services, including water. In fact, my imagination had led me to believe that Dar es Salaam residents, did not have any water problems. I was wrong. I spent two years as a high school student seeing, experiencing, and feeling the problem of water in the city. The problems included: dilapidated infrastructure, which could not cope with the growing population, vandalism of water infrastructure, water theft, corruption and managerial issues. I continued to experience the water challenges at the university level and even when I started living in a rented apartment in the city. There was a public outcry with regard to access to clean and safe water.

The Sensors, Empowerment and Accountability (SEMA) research project, which sponsored my $\mathrm{PhD}$ study became a perfect academic opportunity to ponder the question as to why access to clean and safe water remain a huge challenge in Tanzania despite significant investments by government 
officials and donors. The four years (2012-2016) of my $\mathrm{PhD}$ research under excellent profession supervision of my promoters, supervisors, mentors and interactions with practitioners in private and public organisations, made me understand that water problems in Tanzania have their own politics which are located in the power relations between Tanzanian public officials and donors. These power relations are informed by an interplay of different and often conflicting governmentalities which give rise to complex and self-contradictory drivers, the result of which is that formal international donor accountability reforms are difficult to implement and can lead to counterproductive results. Thus, holding national and local level public officials to account should not be understood only through the lenses of principal-agent (PA) and collective-action (CA) theory, because these do not capture all drivers and interactions.

In the course of doing my $\mathrm{PhD}$, many people and organizations assisted me directly or indirectly in shaping this thesis, although I remain personally responsible for any errors and foibles. Before acknowledging their contribution in helping to bring this thesis to academic fruition, I would like to thank almighty God for his guidance and protection in the course of doing my $\mathrm{PhD}$.

I acknowledge the financial support of the research programme Sensors, Empowerment and Accountability (SEMA) in Tanzania funded by the Netherlands Organization for Scientific Research-Science for Global Development (NWO-WOTRO). This thesis was funded by NOWWOTRO. Thanks to the SEMA project leader, Professor, Yola Georgiadou for selecting me to pursue a PhD in the SEMA research project. Your immense contribution to my intellectual growth is beyond measure and will forever be appreciated. You taught me to avoid 'rumblings' in writing by imagining that I write to my 90 year old grandmother in the village!

Special thanks to Professor Robert Hoppe for supervising my thesis. Prof. Hoppe, your intellectual influence was never entirely confined to the written literature that you constantly assigned me to interrogate, but was part of the daily inspiration of teaching, mentoring, and learning that came from various academic engagements, formal and informal, we had in the past four years. Thank you for strengthening my argumentation style by clarifying core concepts and assertions of my research; correcting theoretical notions used in the thesis that seemed not in agreement with my arguments and the main theory.

You exposed me to very interesting literature on Africa and Tanzania which, admittedly, I had not come across. Your suggestions that I attend various summer schools and conferences not only benefited me intellectually but socially and culturally as well, for I managed to travel in different countries and learn other people's culture. In particular, my travel to Ankara, Turkey for summer school expanded my knowledge on qualitative and quantitative data analysis techniques, i.e. leximancer, Nvivo, ATLAS.ti, software, etcetera. Indeed, my work benefited from the knowledge I obtained from that training. My travel to Poland was captivating and intellectually-stimulating. I got a chance to present my own research work at the University of Warsaw before a panel of reputable scholars drawn from the European Consortium for Political Research (ECPR). The accountability conference we organised together in Dare es Salaam left an indelible mark of scholarship among fellow academic colleagues at the Department of Political Science and Public Administration of the University of Dar es Salaam. I benefited from the contributions that came from that workshop to improve some of the chapters in the thesis. Last, but very important, thanks for teaching me the art of writing publishable academic papers. I consider this as unparalleled intellectual gift in my future academic carrier. 
I am very grateful to Dr. Anna Wesselink as a daily co-supervisor. A very big thank you for the incredible support, persistent motivation to work hard and unwavering mentoring. You always pushed me to the edge and gave objective opinion no matter how I would feel. Although, at times, this seemed unendurable, but over time I came to understand and appreciate that your goal was to help me produce a quality thesis. Thanks for the interesting discussions, formal and informal, we had in a span of four years. The discussions were candid and most of the time thought-provoking. Your intellectual and logistical guidance during the field work activities in Tanzania was unparalleled and will forever be appreciated. Your constant and rigorous word to word edits during the formative stages of the thesis was very helpful in making the thesis legible. Your constant insistence and facilitation that I should attend conferences and present my work is much appreciated. Lastly, many thanks also for encouraging me to travel around in the Netherlands and other countries that I went for intellectual activities. I have beautiful collection of memories from the Netherlands and other countries which I owe credit to you.

I would also like to acknowledge the good work of Dr. Annalisa Pelizza as a daily co- supervisor. Dr. Pelizza was involved in supervising my thesis writing process supporting the activities of my main promoter, Prof. Robert Hoppe and a daily co-supervisor, Dr. Anna Wesselink. Thank you for the detailed and robust commentary on my draft chapters which made it easy to understand the comments and work on them. Your constructive criticisms on my draft empirical chapters, including my research design helped me to refine the chapters in a coherent way. Your knowledge on digital technologies and governance issues, which I also address in one of my thesis chapters was of great intellectual value addition to my thesis.

Many thanks go to Dr. Benson Bana from my home country, Tanzania. By the time I successfully obtained the SEMA PhD scholarship, Dr. Bana was the head of Department of Political Science and Public Administration, University of Dar es Salaam, where I work as an Assistant Lecturer. He made sure that I complete all the necessary administrative requirements, including applications for study leave and other logistics before I could travel to the Netherlands. Your contribution to my intellectual growth through various academic engagements is very much appreciated. You never got tired to push me to work hard and complete my studies on time.

I convey a vote of thanks to all members of the SEMA research project whom we interacted together in the course of doing my PhD. In no particular order, I thank Mr. Jeroen Verplanke, Prof. Rob Lemmens, Prof. Menno-Kraak, Prof. Javier Martinez, Dr. Juma Lungo, Dr. Mercy Mbise and Mr. Charles Bundu. I also thank my fellow PhD students in the SEMA research project, Mr. Kapongola Nganyanyuka and Mr. Habtom Tsega. The four years we worked together were memorable and I benefited a lot from various academic and social engagements we had. Special thanks also go to all library staff of ITC, Petra Weber of the Urban Planning Department, Marion Pierik of the Finance Department and Eveline Bonte of the Department of Science, Technology and Policy Studies (STePS), all from the University of Twente, for unwavering logistical and administrative support in my four years as a PhD student at the University of Twente.

Last but not least, I would like to thank a number of organizations that made this work possible. I thank my employer, the University of Dar es Salaam for granting me study leave for four years. I thank the Department of Political Science and Public Administration of the University of Dar es Salaam for allowing me to present my initial findings during my field work in Tanzania.

I express my gratitude also to many individuals whom I interviewed between 2013 and 2015 in Dar es Salaam, Dodoma and Mara regions of Tanzania. I thank all interviewees in the Ministry of 
Water, Members of Parliament, Councillors and administrative officials in Bunda district, officials working in the BRN programme and individuals working in Civil Society Organisations (CSOs), including Non-Governmental Organisations (NGOs) for their time and patience during the interview process.

My special thanks go to my lovely parents, Mrs. Theodosia Katomero and Mr. George Steven Katomero. Despite your ill-health, sometimes from a hospital bed, you never stopped to encourage me to work hard to complete this work on time. Your love and support over the years has been a key pillar of my academic success. May almighty GOD heal you from your current state of illness to resume your responsibilities. Finally, I would like to thank my best friend, the rock of my life and the mother of my son, Jensen Jesper Katomero, my wife Elizabeth Katorobo for the support and unconditional love in the course of doing my $\mathrm{PhD}$ research. I was away from home most of the time but you endured staying alone. It was a pity that when our son Jensen was born, I was not there for you, but you understood and even encouraged me to work hard to finish my $\mathrm{PhD}$ studies.

Jesper G. Katomero

Dar es Salaam, 10-03-2017 


\section{Table of Contents}

Preface. .. $\mathrm{i}$

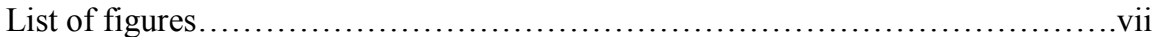

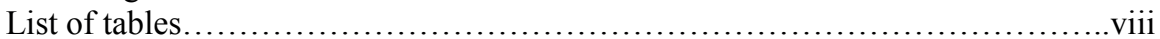

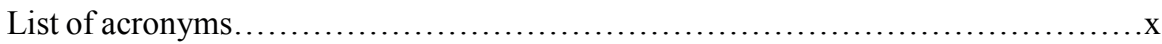

1 Rethinking accountability in the context of governmentality ...............................1

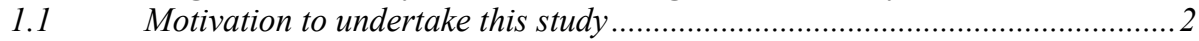

1.2 Accountability in Africa and Tanzania: the governmentality context.............. 3

1.3 Africa's relations with the rest of the world ................................................ 5

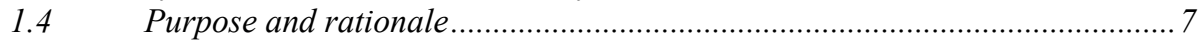

1.4.1 Deteriorated access to clean and safe water in rural and urban settings .......... 7

1.4.2 Alternative views to accountability practices: ................................................ 8

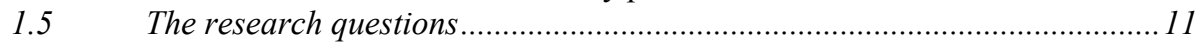

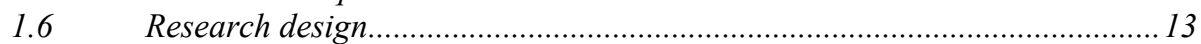

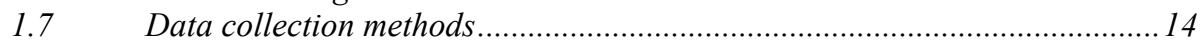

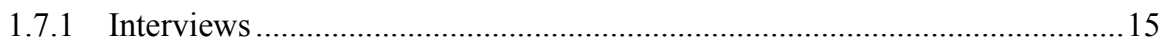

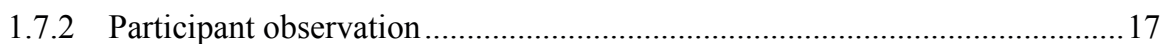

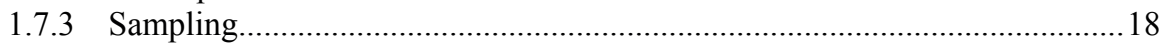

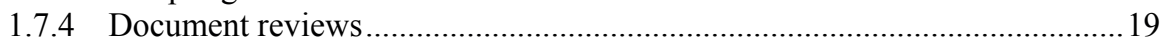

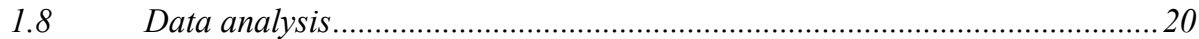

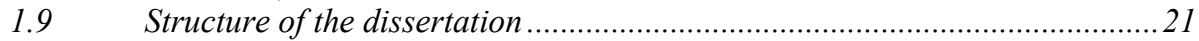

2 Accountability as an element of governmentality: conceptual and theoretical

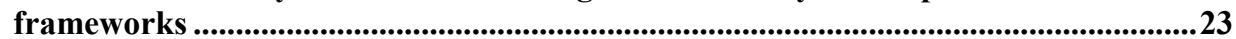

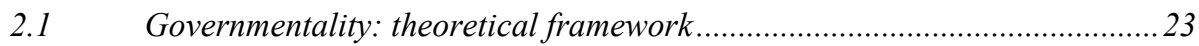

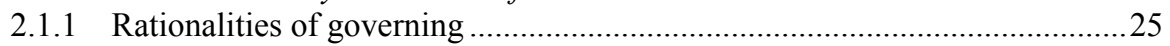

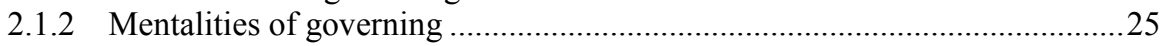

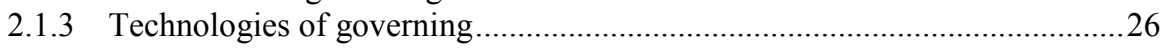

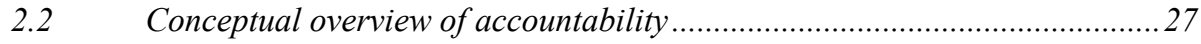

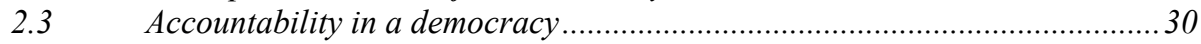

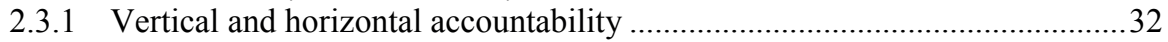

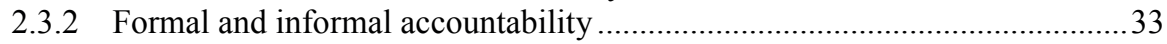

2.3.3 Accountability as an element of governmentality........................................34

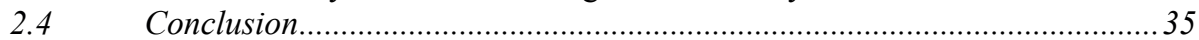

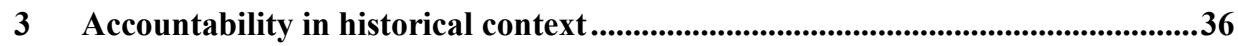

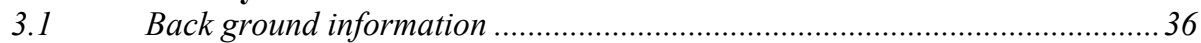

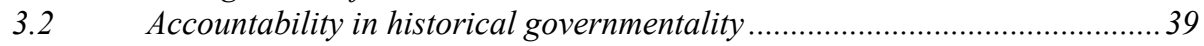

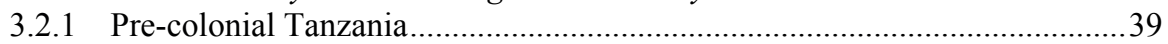

3.2.2 The colonial period: German and British colonial influences........................45

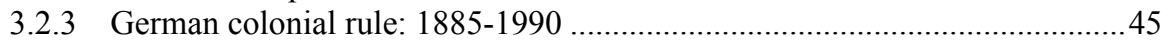

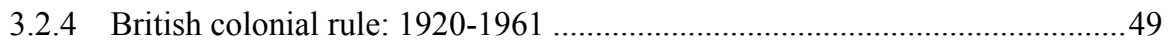

3.2.5 The post-independence period: 1961 - onwards ...........................................53

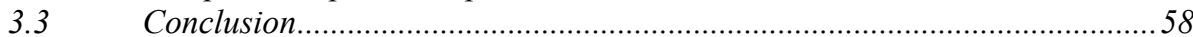

$4 \quad$ Institutional designs for water provision and current accountability practices 59

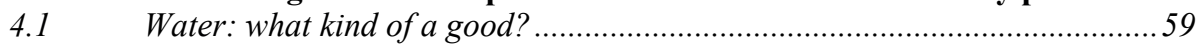

4.1.1 Different goods different institutional designs...........................................5

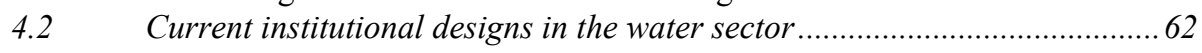


4.3 Current accountability structures at the national government .....................67 67

$4.4 \quad$ Current accountability structures at the local government level ................... 68

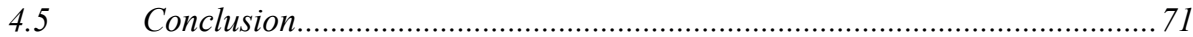

5 National level accountability practices: the case of Tanzanian parliament.........72

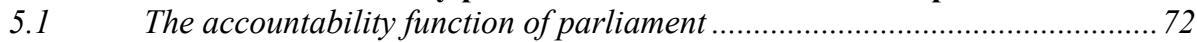

5.2 The Tanzania parliament: history, composition and functions..................... 74

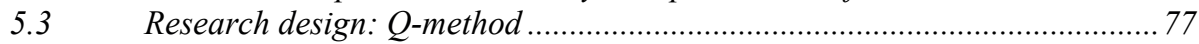

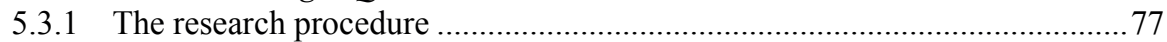

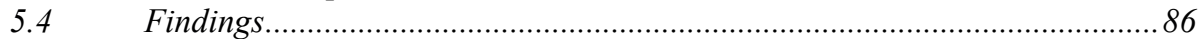

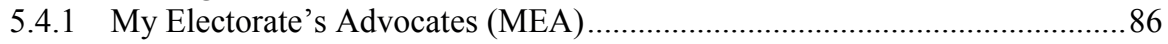

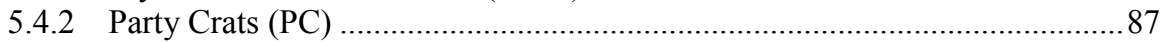

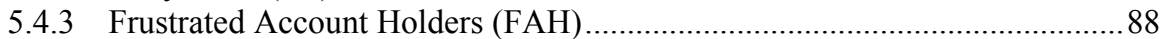

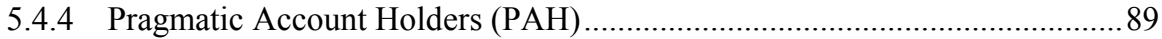

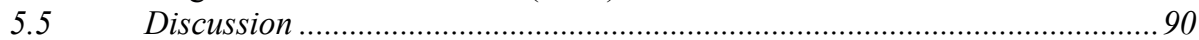

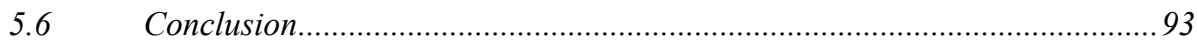

6 Local government accountability practices: a case of rural water supply in Bunda

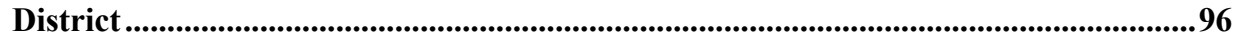

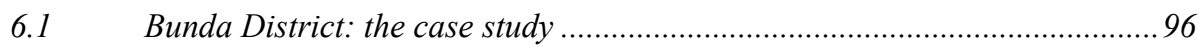

6.1.1 The political and administrative set up ....................................................98

6.1.2 The Political Context...........................................................................................99

6.1.3 The rural water supply situation in Bunda district .......................................99

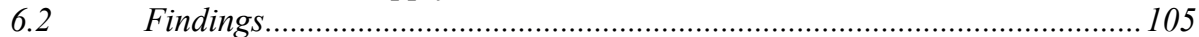

6.2.1 Formal Institutions that should structure public official's behaviours......... 106

6.2.2 Competition between formal and informal accountability mechanism ....... 107

6.3 The influence of transnational policies and governmentalities on local water

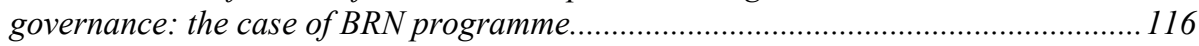

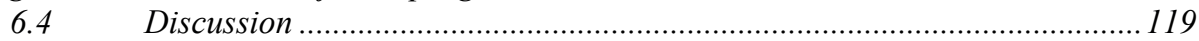

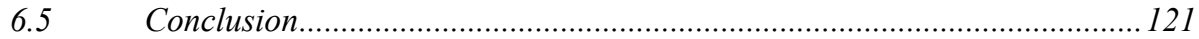

7 ICTs-induced accountability interventions: the case of the WPM system and the SEMA mobile phone application ..........................................................................122

7.1 ICTs and accountability in the rural water sector ...................................... 122

7.2 The water mapping system in the $\mathrm{MoW}$........................................................ 124

7.3 SEMA mobile phone reporting ...................................................................... 128

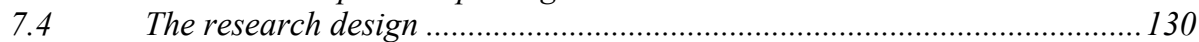

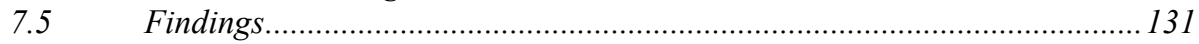

7.5.1 Internal bureaucratic politics and conflicts .............................................. 131

7.5.2 Interest in collecting information on new water projects ........................... 133

7.5.3 Willingness to accept the SEMA mobile phone reporting application ......... 133

7.5.4 Why digitised information would (not) change existing informal information

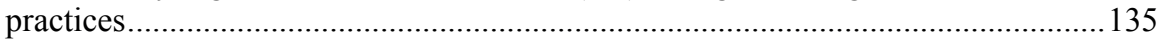

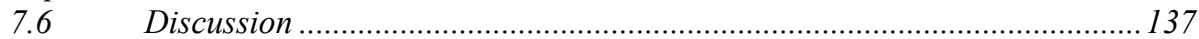

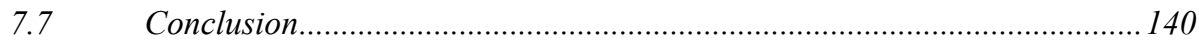

8 Conclusion: going with the grain or against the grain.....................................142

8.1 The governmentality approach revisited................................................. 142

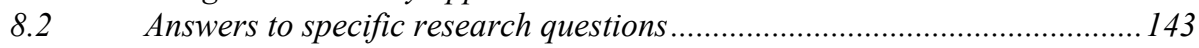

8.3 Exploring governmentality in Africa deeper and wider.............................. 155

8.4 Going with the grain or against the grain.................................................... 157

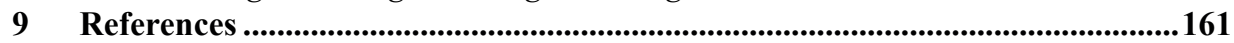




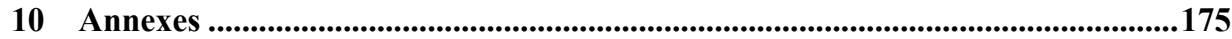

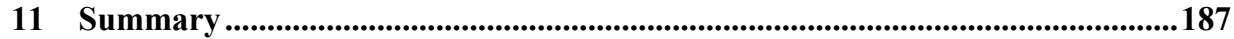

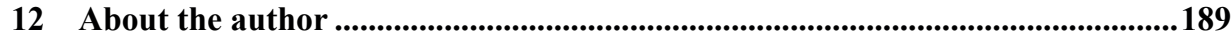




\section{List of figures}

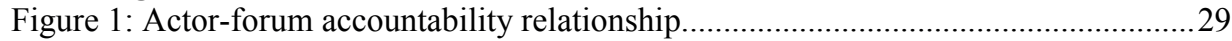

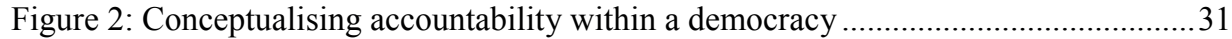

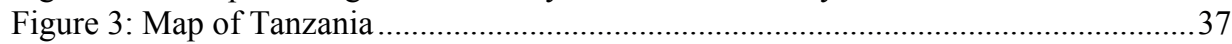

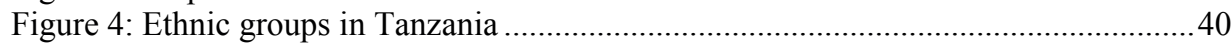

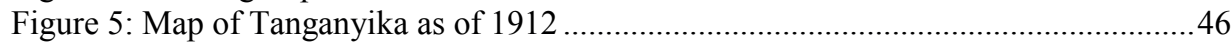

Figure 6: Institutional framework for water supply and sanitation................................63

Figure 7: Political and administrative officials at national and local governments ............70

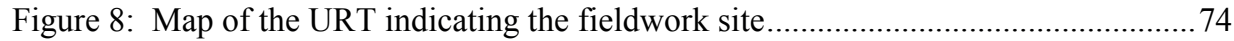

Figure 9: Practical steps in doing Q method research ................................................... 78

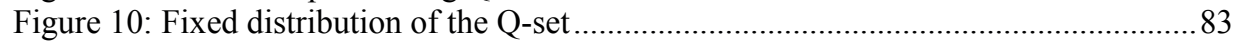

Figure 11: Typology of accountability discourses (after Hyden 2010) ...........................92

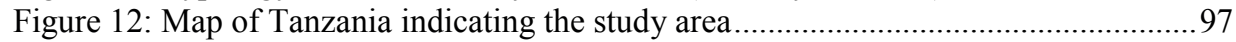

Figure 13: World Bank and other international donor's in rural water projects .............. 104

Figure 14: Formal accountability requirements in rural water supply in Bunda ............. 107

Figure 15: Informal accountability mechanisms in in Bunda ........................................ 111

Figure 16: National, regional and district accountability chains in the water sector after the

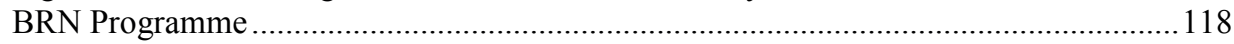

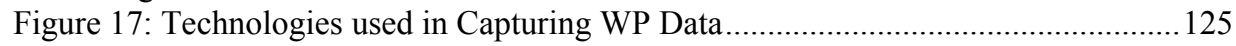

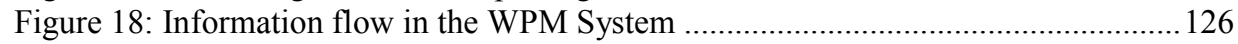

Figure 19: A snapshot of the WPM system website of the MoW ...................................127

Figure 20: A Snapshot of the status of water points in Bunda district..............................127

Figure 21: A snapshot of the statistical graph generated from the WPM system on MoW

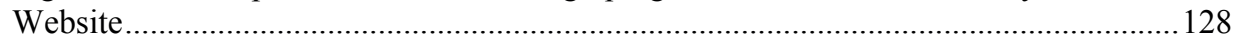

Figure 22: SEMA mApp: USSD (left) and android (right) implementations................... 130

Figure 23: The location of four wards: Mcharo, Kasahunga, Nyamuswa and Balili....... 131 


\section{List of tables}

Table 1: Data sources for this dissertation 14

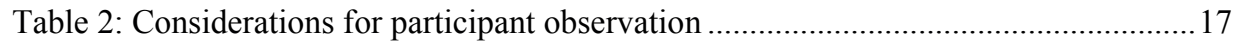

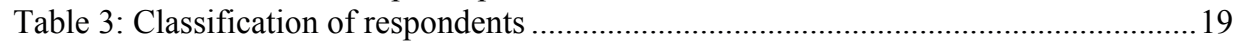

Table 4: Conceptual summary of elements of governmentality ......................................2 27

Table 5: A summary of R-M-Ts during pre-colonial, colonial and post-colonial periods. 57

Table 6: A summary of responsibilities of actors in the water Sector, ...............................64

Table 7: Parliamentary votes and seats in the 2010 union elections ................................ 75

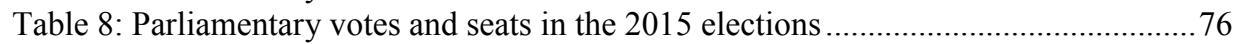

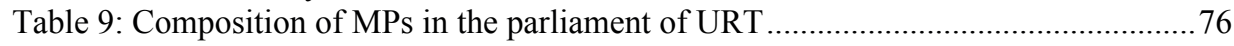

Table 10: Standardized factor Q-sort values for each statement........................................79

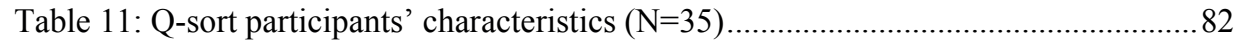

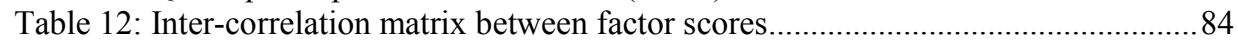

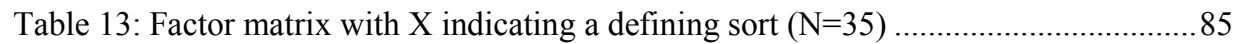

Table 14: Accountability types of MPs compared to NPM-type accountability ...............95

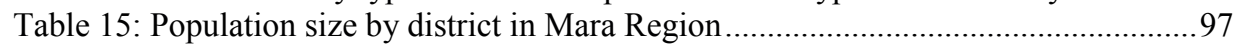

Table 16: The political and administrative set up of Bunda district ................................98

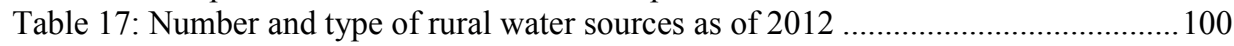

Table 18: Number and type of technology used in rural water schemes as of $2012 \ldots \ldots . .100$

Table 19: Percentage of rural population served with clean water in 2012 .................... 101

Table 20: Summary of conflicting governmentalities on ICT-induced accountability

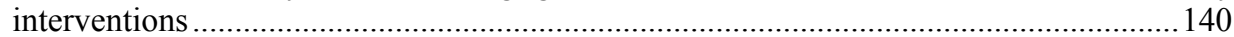

Table 21: Summary of conflicting governmentalities from pre-colonial to the current period 


\section{List of acronyms}

\begin{tabular}{|c|c|}
\hline ACT & Alliance for Change and Transparency \\
\hline $\mathrm{AD}$ & Anno Domini \\
\hline $\mathrm{ADB}$ & African Development \\
\hline AFD & French Development Agency \\
\hline BRN & Big Results Now \\
\hline CBOs & Community Based Organisations \\
\hline CCM & Chama Cha Mapinduzi \\
\hline CHADEMA & Chama Cha Demokrasia na Maendeleo \\
\hline CHRGG & Commission for Human Rights and Good Governance \\
\hline COWSOs & Community Owned Water Supply Organisations \\
\hline CSOs & Civil Society Organisations \\
\hline CUF & Civic United Front \\
\hline DANIDA & The Denmark International Development Agency \\
\hline DED & District Executive Director \\
\hline DFID & Department for International Development \\
\hline DWE & District Water Engineer \\
\hline EKN & Embassy of the Kingdom of the Netherlands \\
\hline ES & Ethics Secretariat \\
\hline EU & European Union \\
\hline EWURA & Energy and Water Utilities Regulatory Authority \\
\hline FAH & Frustrated Account Holders \\
\hline FBO’s & Faith Based Organisations \\
\hline GTZ & German Technical Cooperation Agency \\
\hline HESAWA & Health Sanitation and Water Project \\
\hline ICT & Information Communication Technology \\
\hline IDGIS & The Netherlands International Development Agency \\
\hline IMF & International Monitory Fund \\
\hline JICA & Japan International Cooperation Agency \\
\hline KFW & Kreditanstalt Fur Wiederaufbau \\
\hline LEGCO & Legislative Council of Tanzania \\
\hline LGAs & Local Government Authorities \\
\hline MCC & Millennium Challenge Corporation \\
\hline MDGs & Millennium Development Goals \\
\hline MEA & My Electorate Advocates \\
\hline MIS & Management Information Systems \\
\hline MoHSW & Ministry of Health and Social Welfare \\
\hline MoW & Ministry of Water \\
\hline MPs & Members of Parliament \\
\hline NBS & National Bureau of Statistics \\
\hline NCCR-Mageuzi & The National Convention for Construction and Reform \\
\hline NEC & National Electoral Commission \\
\hline NGOs & Non-Governmental Organizations \\
\hline NLD & National League for Democracy \\
\hline NORAD & The Norwegian Agency for Development Cooperation \\
\hline
\end{tabular}




\begin{tabular}{|c|c|}
\hline NPM & New Public Management \\
\hline NSGRP & National Strategy for Growth and Reduction of Poverty \\
\hline NWSDS & National Water Sector Development Strategy \\
\hline OECD & Organization for Economic Cooperation and Development \\
\hline P-A & Principal Agent Theory \\
\hline PAH & Pragmatic Account Holders \\
\hline PATA & Public Accountability in Tanzania \\
\hline $\mathrm{PC}$ & Party Crats \\
\hline PCCB & Prevention and Combating Corruption Bureau \\
\hline PMO-RALG & Prime Minister's Office Regional Administration and Local Government \\
\hline RAS & Regional Administrative Secretary \\
\hline REPOA & Research on Poverty Alleviation \\
\hline RWA & Rural Water Advisors \\
\hline RWSSP & Rural Water Supply and Sanitation Programme \\
\hline SAPs & Structural Adjustment Programmes \\
\hline SEMA & Sensors Empowerment and Accountability \\
\hline SIDA & Swedish International Development Cooperation Agency \\
\hline SNV & The Netherlands Development Organisation \\
\hline $\mathrm{TZ}$ & Tanzania \\
\hline TANU & Tanganyika African National Union \\
\hline TLP & Tanzania Labour Party \\
\hline UDP & United Democratic Party \\
\hline UK & United Kingdom \\
\hline UKAWA & Umoja wa Katiba ya Wananchi \\
\hline UNDP & United Nations Development Programme \\
\hline UNEP & United Nations Education Programme \\
\hline UNICEF & United Nations Children’s Fund \\
\hline URT & United Republic of Tanzania \\
\hline UWSSP & Urban Water and Sewerage Programme \\
\hline VEO & Village Executive Officer \\
\hline VNG-I & International Cooperation Agency of the Association of Netherlands \\
\hline WB & World Bank \\
\hline WDCs & Ward Development Committees \\
\hline WDSPs & Water Sector Development Programmes \\
\hline WHO & World Health Organisation \\
\hline WPM & Water Point Mapping \\
\hline WPs & Water Policies \\
\hline WSRPs & Water Sector Reform Programmes \\
\hline WSSA & Water Supply and Sanitation Authoritie \\
\hline
\end{tabular}




\section{Rethinking accountability in the context of governmentality}

In this dissertation I delve into the accountability landscape in Tanzania, focusing on water service delivery. The overall research question I investigate is how public officials are held to account in the context of water supply in Tanzania. To find answers to this question, I analyse accountability relationships at four levels of governance: First, I focus on the national level where I analyse the accountability relationship between parliament and the executive. Parliament, after all, is the forum at the epicentre of a democratic political system. Accountability practices in the parliamentary arena are expected to have an emblematic, illustrative and imitative function for all other accountability forums in a nation, including local levels of governance. Second, I examine accountability relationships between the local council and the local executive in a rural water supply context. Third, I analyse accountability chains in an intergovernmental dimension between the Ministry of Water (MoW), the regions and the districts. Finally, I investigate the possibility of using ICT/mobile phone-driven accountability interventions in the MoW and the local government authorities in Tanzania. My dissertation is distinguished from other accountability studies in that it attempts to explain how actual accountability practices work in a context of governmentality. I locate the present study in a wider context of African and Tanzanian relations with the outside world in different historical periods. I argue that these relations have a bearing on the current accountability practices in general and in the water sector in particular.

As I read around the subject of accountability, I noticed that scholars and practitioners have a strong recurrent interest in the issue both in developing and developed countries. This interest, as suggested by Bovens (2005), emanates from the fact that the subject of accountability is often linked to an image of transparency and trustworthiness. This positive framing of accountability has fuelled the drive to strengthen accountability institutions which, it is believed, will fast- track socio-economic development, particularly in developing countries. The interest in accountability is expressed in policy discourses, academic writings, reform initiatives, and within the international community which is led by the International Monetary Fund (IMF) and the World Bank (WB) in Africa (Andrew, 2013; Booth, 2011; Bratton and Logan, 2014; Grindle, 2010; Hyden, 2013; Kelsall, 2008; Lindberg, 2010; Melber, 2007; Transparency International, 2014; Walle, 2009; WB, 2004) as well as in Tanzania (Bratton, 2010; Carlitz, 2013; Heilman and Ndumbaro, 2002; Hoffman, 2010; Hyden, 2010; Khan and Gray, 2006; Kelsall, 2003; Kersall and Muya, 2004; Killian, 2014; Lawson and Rakner, 2005; Lindner and Banoba, 2014; Mallya, 2011; Matenge, 2012; Mwakyembe, 1985; Rottenburg, 2002; Schatz, 2013; Shivji et al., 2004; Tambila, 2004; Therkildsen, 2000; Tilley, 2014; Tsubura, 2014).

Accountability advocates within such institutions, too, often acknowledge that accountability has remained one of the most difficult and contested subjects both to conceive and to act on. African and Western scholars alike acknowledge this awkwardness in their studies (Borowiak, 2007; Bovens, 2010; Brandsma, 2010; Dubnick and Justice, 2004; Dubnick, 2005; Hyden, 2010; Hyden, 2013; Lindberg, 2009; Schliemann and Bovens, 2010; Sinclair, 1996; Tilly, 2014). I attribute this difficulty to the fact that accountability is a thoroughly political notion. It is an umbrella concept touching upon almost all facets and aspects of the drive for 'democracy' and 'good governance' which are interpreted and understood in different ways across countries. In this case 'accountability' is not only a politically contested notion, but a so-called 'boundary object' that 
allows for cooperation without any formal agreement on the meaning of the term (Star and Griesemer, 1989).

Despite the lack of consensus on the definition and the subsequent practical application of the term, accountability has remained a buzz-word in the Washington Consensus ideas about economic development and in concomitant funding programmes of the WB, IMF, the Organisation for Economic Co-operation and Development (OECD), and even in funding programmes of Non-Governmental Organisations (NGOs) or donors who give funds to charities. The pressure by international organisations and donors to make African governments more accountable has been exerted for decades. The organisations and donors have always linked accountability with the improvement of public service delivery. The water sector in sub- Saharan African countries, including Tanzania, is a case in point. Accountability is, therefore, a key determinant in defining power relations between African and western countries or donors in terms of foreign aid and reform packages to improve public service delivery. This is exemplified by programmes funded by the World Bank in Africa through the Water Sector Development Programmes (WSDPs), Water Sector Reform Programmes (WSRPs) and the subsequent Water Policies (WPs).

This study locates accountability practices within a kind of governmentality in which different and often conflicting dynamics are closely intertwined. This situation gives rise to complex and self-contradictory drivers, which in turn, make the proposed accountability reforms difficult to implement.

\subsection{Motivation to undertake this study}

The motivation to undertake this study is first of all personal. However, it is also based on my perception of general flaws in the donor driven accountability projects in the water sector, since these encounter practices of mischaracterizing the water problem with the aim of pursuing 'strategies of extraversion' by public officials'.

Growing up as a young boy in Kigoma, a remote region in the western part of Tanzania, I did not experience any water problems. Every day we had access to pipe-borne water at home. This experience changed when I was enrolled in a boarding secondary school, in the1990s, in the neighbouring region of Tabora located about $400 \mathrm{~km}$ east. There was no pipe-borne water in our school. The main source of water was wells and ponds. At times, we travelled long distances to fetch water, especially during the dry season. During the rainy season, drinking water was 'brown coloured' and there was no bottled water at the time. There was no water treatment technology either. We had no option but to accept the tough reality. There were several cases of water-borne diseases afflicting students. The impact was felt by many students who could not take exams, who postponed studies etc. Luckily, I did not suffer from any waterborne diseases.

Five years later, I moved to Dar es Salaam for advanced level studies. I was accommodated by my elder brother who had settled in the city. I had imagined Dar es Salaam as a big city with high quality social services, including water. In fact, my imagination had led me to believe that Dar es Salaam residents, including my brother, did not have any water problems. I was wrong. I spent two years as a high school student seeing, experiencing, and feeling the problem of water in the

\footnotetext{
${ }^{1}$ Extraversion implies practices for acquiring material resources and power by brokering trade deals with foreign partners
} 
city. During that time, I heard on the radios and read on newspapers, that the water supply authorities were addressing major water problems. I also saw it on television. The problems included: dilapidated infrastructure, which could not cope with the growing population, vandalism of water infrastructure, water theft, corruption and managerial issues.

A few years later, I joined the University of Dar es Salaam as an undergraduate student in the Department of Political Science and Public Administration and I experienced the same problems at the university. Although there was pipe-borne water at the university, there were frequent water rationing, power outages, vandalism of water infrastructure etc. Water pipes burst frequently as well. After completing my studies, I was employed by the university and started living in a rented apartment in the city. The situation was the same; there was no pipe- borne water in my apartment. My landlord, his family and I depended on salty water from a well, constructed by the land lord on his compound. These personal experiences reflect those of many Tanzanians in the urban and rural areas.

Years later, it was announced at the university that members of the academic staff could apply for $\mathrm{PhD}$ scholarships to the Sensors, Empowerment and Accountability (SEMA) research project, a joint research programme under the University of Dar es Salaam and the University of Twente. The SEMA research project aimed to contribute to the improvement of water services in Tanzania by exacting accountability from water service providers. This was a unique intellectual opportunity for me to research into the water problem in Tanzania that coincided with my personal experiences. Although the SEMA research project is not a 'silver bullet' with which one can address the water problem in its entirety, it does contribute to the efforts by various people and organisations to address the problem.

With time, I have come to understand that water problems have their own politics which are located in the power relations between Tanzanian public officials and international donors. These power relations are informed by a particular governmentality that is important to understand in order to devise possible interventions. Thus, the political motivation for me to undertake this research stems from my observation of the general flaws in the donor-driven accountability reform initiatives in the water sector. These are concurrent with practices of national and local government public officials that mischaracterise water supply problems in their own interest. The late father of the nation Mwalimu Julius Kambarage Nyerere once said: 'Intellectuals have a special contribution to make to the development of our nation, and to Africa. And I am asking that their knowledge, and the greater understanding that they should possess, should be used for the benefit of the society of which we are all members' (Nyerere 1967). By investigating accountability practices in Tanzania at the national and local levels, I heed this call and aim to contribute to the efforts to address the water problem in Tanzania.

\subsection{Accountability in Africa and Tanzania: the governmentality context}

The concept of governmentality, coined by Foucault, (1997:68) is mainly used by scholars and practitioners in the west. The reason for this may be that the concept was originally formulated and applied in a western context. As a result, the application of the governmentality concept in an African context is usually criticized on the ground that Africa is a different, non- liberal/western entity (Death, 2011:1; Sigley, 2006, cited in Lemke, 2007:4). African politics are apparently far removed from the liberal European societies in which Foucault's work was grounded (Death, 2011:1). 
However, despite this criticism, I subscribe to Carl Death who argues that 'by treating governmentality as an analytical approach rather than a specifically neoliberal form of power relation, it can have considerable purchase in non-liberal societies, and can also tell us something interesting about the unevenness of contemporary global politics, including forms of power and agency that work through practices of freedom and self-government' (Death, 2011:1). Therefore, the term governmentality is used here to illuminate a range of particular and historically specific Rationalities, Mentalities, and Technologies (R-M-Ts) of governing that have influenced modern/current accountability practices. These practices are understood in the context of historical relations between Africa and western countries from the pre-colonial period through the colonial period to the post-independence period.

In a broad sense, the term governmentality denotes a conglomeration of techniques and procedures for directing human behaviour, i.e. the government of children, of souls and of conscience, of a household, of a state, or of oneself (Foucault, 1977:82). However, the starting point for understanding governmentality is to see it as a particular way of 'how we think about governing with different rationalities, mentalities and technologies' (Miller and Rose, 1990; Rose and Miller, 1992, cited in Dean, 2010:24). Understood as a particular way of thinking about governmental practices, governmentality is also concerned with the analysis of thought as it is linked to and embedded in technical means for the shaping and reshaping of conduct and in practices and institutions (Foucault, 1977). Thus, governmentality is an interface between the personal and the collective/state - a mixture of notions of disciplining people from above and notions of selfdiscipline. The former would be ineffective if it would not plug into the conduct of the latter. There are three main constitutive elements of governmentality: rationalities, mentalities and technologies (R-M-Ts).

Rationality means any way of reasoning, or a way of thinking about, calculating and responding to a problem, which is more or less systematic, and which might draw upon formal bodies of knowledge or expertise (Dean 2010:24). Rationality is linked to moral questions. Here, morality is understood in two ways: it implies an attempt to make oneself accountable for one's own actions; and as a practice in which human beings take their own conduct to be subject to selfregulation (Dean, 2010:19). In that case, the rational attempt to shape the conduct of subjects becomes a key feature of government. Thus, viewing government rationality in terms of morality, government becomes an intensely moral activity because policies and practices of government at the national and local government levels presume to know, with varying degrees of explicitness and using specific forms of knowledge, what constitutes good, appropriate, responsible conduct of individuals and collectivities (Dean, 2010:19).

A mentality is a condition of forms of thought which cannot be easily understood within its own perspective (Dean, 2010). It involves unreflexive, cultural and tacit knowledges which we are immersed in, like a fish who does not know the concept of 'water'. In this case, a mentality involves collective thinking and not just a matter of representations of individual mind or consciousness, but of the self-evident and unquestionable stocks of knowledge, belief and opinion in which we are immersed (Dean, 2010:27). For example, mentalities associated with being a master or a slave without questioning your position in life. Thus unlike, rationality, a mentality is a collective, relatively bounded unit unity, and is not readily examined by those who inhabit it. 
Technologies, on the other hand, refer to multi-faceted practical mechanisms, procedures, instruments and calculations through which authorities guide and shape the conduct and decisions of others in order to achieve specific objectives (Lemke 2007:9). Thus, the meaning ascribed in the technologies of governing has to do with the shaping of conduct to produce desired effects and mitigating undesired ones (ibid). In this regard, a distinction is usually made between technologies of the self and political technologies (Rose, 1999; Lemke, 2011). Technologies of the self focus on processes of self-guidance and the ways by which citizens relate to themselves as ethical beings (Lemke, 2011). Political technologies denote the way by which citizens have been led to recognize themselves as a society, as a part of a social entity, as a part of a nation or a state (Foucault, 2000b:404).

What is important with regard to the R-M-Ts of governing, is understanding how and why they influence accountability practices at the transnational, national and local government levels. This is especially critical when one is examining accountability practices in Africa in general and Tanzania in particular.

\subsection{Africa's relations with the rest of the world}

The relations between Africa and the rest of the world did not develop overnight. Understanding these relations is crucial to grasping accountability practices in general and in the water sector in particular. Thus, Africa's engagement with the rest of the world is important for understanding both politics and development on the continent (Hyden, 2013:209). The relations began at the time of Africa's early contact with the outside world.

In his thought-provoking book, The State in Africa: The Politics of the Belly, Jean Francois Bayart (2009) explains the relations between Africa and the outside world, including the subsequent impact of the relations on Africa's future power-politics. On this account Bayart writes:

"Considered in a view of history over the longue durée, Africa has never ceased to exchange both ideas and goods with Europe and Asia, and later with Americas. The antiquity of Christianity in Ethiopia, the spread of Islam on the coasts, the establishment of Austronesian colonies in Madagascar, regular patterns of trade with China, India, the Persian Gulf and the Mediterranean are all evidence of the degree to which eastern and southern Africa were for centuries integrated into the pre-modern economic systems of what scholars used to call the Orient" (Bayart, 2009: 11)

In particular, Bayart's work on the historical sociology of the state in Africa provides a useful starting point for understanding how various governmentalities have defined African's relations with western countries over time, thus making them critical in the understanding of the current governance and accountability practices on the continent. Bayart was motivated by the desire to recapture an active African political subject, while at the same time rejecting the passivity of the dependency theory account, but remaining sensitive to historic inequalities of power and wealth (Death, 2011:6).

Power and wealth were among the key political features of the pre-modern economic systems in Africa as the continent interacted with the rest of the world. For instance, forms of political organization in Africa were strengthened, to an extent, based on power and wealth that was 
acquired through military conquests from within the continent and trade dealings with traders from Asia, Europe and the Arab world.

During the early contact with Asians, Arabs and European traders in the early 15th century, Africans played a very active role in trade activities. African decision-makers were at the epicentre of these trade dealings. This enabled them to acquire power and resources which, in turn, allowed them to govern their communities. African decision makers played a more pronounced role (voluntarily) through deliberate recourse to the 'strategies of extraversion', a term that means practices for acquiring material resources and power by brokering trade deals with foreign partners (Bayart, 2009:12).

The concept of extraversion draws upon the Foucauldian notion of governmentality to explain that the forms of rule practiced by African decision makers in a position of authority were characterized by the mobilization of resources derived from their (possibly unequal) relations with the outside world (Death, 2011:6). The resources were internally derived, but exchanged in a transnational context. They included ivory, slaves, guns, gold and tributes paid in trade routes such as the famous 'long distance trade' conducted between the east coast of Africa and inland Tanzania. The fact that most of the trade dealings were under the control of African rulers, made them powerful internally. Therefore, Bayart argues that African dependency (or inequality) on international agents and structures has nevertheless been a major resource in the process of political centralization and economic accumulation (Bayart, 1999; Bayart, 2009; cited, in Death, 2011:6).

However, the immediate consequence of this phenomenon was the integration of Africa into the pre-modern economic system, making Africa an explicit dependent partner (Bayart, 2009). The international aid regime and other forms of bilateral and multilateral aid relations between Africa and the developed world are a manifestation of this apparent dependence relationship stemming from the early contact. In essence, this also influenced and characterized how African rulers viewed their relations with the outside world and their communities (Bayart, 2009). This relationship is based on personal accumulation of wealth as well as on the use of such wealth to govern one's own community.

Thus, in the context of the 'dependence phenomenon' and 'strategies of extraversion', the practices of governance in Africa were centred on the satisfaction of immediate and personal interests and wishes achieved through the colonial state system's apparatus (Bayart, 2009). This practice was made possible by the role played by African intermediaries and indigenous bureaucrats, who operated within the colonial system and who in return for their service were allowed to gain concessions from their positions and power for their specific regions or ethnic communities (ibid). This marked the beginning of overlapping circles of subordination, with powerful individuals at the centres, and their entourage gravitating around them (Bayart, 2009). This would later define the power relations between African states and societies but also with foreign actors.

Bayart's argument is particularly relevant for understanding accountability practices within the context of governmentality because of its explicit theorization of African societies as historical and political entities. Although Bayart's work covers Africa in general, his theoretical accounts, particularly that of the dependency phenomenon and strategies of extraversion, are relevant for 
Tanzania as they illuminate governance practices of pre- colonial, colonial and post-independence accountability practices.

In Tanzania, accountability practices and water service delivery governance may be understood in the governmentality as explained above and which consists of three historical periods: the precolonial period, the colonial period and the post-independence period. These phases will elaborated upon in chapter three.

\subsection{Purpose and rationale}

The overall objective of this study is to investigate how public officials were held to account in the context of water service delivery in Tanzania. A secondary objective is to examine the potential of using ICT/mobile phone technologies to strengthen accountability in the water sector in Tanzania. The rationale behind the study was drawn from two problematic areas related to water and accountability practices in Tanzania: the deteriorated quality of water services, including access to clean and safe water in rural and urban settings; and the flaws in donor-national government official's accountability driven practices.

\subsubsection{Deteriorated access to clean and safe water in rural and urban settings}

The dire need for access to clean and safe water of the urban and rural populations in Africa and Tanzania cannot be over-emphasized. Access to safe water is crucially important for human health and wellbeing, and recently it has become one of the most fundamental human needs and rights (Chowns, 2014:3; UN, 2010).The Tanzania water policy of 2002 reckons and acknowledges the same, stipulating that safe drinking water and good sanitation practices are important to human health (URT, 2002:4). Likewise, water occupies centre stage in the 2025 development vision of the country and the poverty reduction strategies articulated in the Poverty Reduction Strategy Paper (PRSP) of 2010.

Various national and international efforts have been made to improve access to clean and safe water in the country. The local efforts include: the formulation of policies, and legal and institutional frameworks to oversee the water sector. At the global level, the Millennium Development Goals (MDGs) set a global goal of ensuring the provision of clean and safe water by 2015 . In particular 'Goal 7, Target $C$ was to halve, by 2015, the proportion of the population without sustainable access to safe drinking water and basic sanitation' (UN, 2013, cited in Chowns, 2014:4). 'Progress towards this target has been monitored by a biannual report from the Joint Monitoring Programme (JMP) of the World Health Organization (WHO) and United Nations Children's Fund (UNICEF). While the latest JMP report shows that the MDG drinking water target has already been met, five years ahead of schedule (JMP 2012a), it also notes that progress has been very uneven and that huge disparities remain, both between and within countries' (Chowns, 2014:5).

Tanzania is amongst the many African countries that have failed to meet the targets. Currently, only $53 \%$ of the citizens have access to clean and safe water (JMP, 2012). Although international donors and national government officials have provided both financial and technical support for decades, the provision of clean and safe water, particularly in the rural areas is still poor. Only around $45-55 \%$ of the rural population has access to clean water from what is termed 'improved' water sources (Jimenez and Perez- Foguet, 2011). However, recent data rank Tanzania with less than $50 \%$ of its population using improved drinking water sources (UNICEF and WHO, 2015). 
The problem of access to clean and safe water in the rural and urban areas in Tanzania is described extensively in the Tanzanian scholarly literature on water (Bouque, 2010; Dill, 2010; Foster et. al., 2012; Jimenez and Perez-Foguet, 2011; Kaliba, 2002; Kassenga, 2007;Kjellen, 2000; Kjellen, 2006; Kroliwoski, 2014; Kyessi, 2005; Marobhe, 2008; Mugisha and Brown, 2010; Nganyanyuka et. al., 2014; Pigeon, 2012; Smiley, 2013; Stalgren, 2006) and in the grey literature on water (Daily News, 2010; EWURA, 2012; JMP, 2012; The Guardian, 2005; Twaweza, 2008; Water Aid, 2008; WHO/UNICEF, 2010; WHO/UNICEF,2012; WHO/UNICEF, 2013).

Mostly, these studies explain why access to clean and safe water has declined in the urban and rural areas in Tanzania over the years and recommend solutions to address the problem. They identify challenges such as: dilapidated infrastructure (Daily News, 2010; Dill, 2010; The Guardian, 2013; Kjellen, 2006), community-based urban water management in fringe neighborhoods and participatory evaluation of community-based water and sanitation programmes (Kaliba, 2002; Kyessi, 2005), corruption (Kroliwoski, 2014; Stalgren, 2006), rendering existing water services more sustainable for the citizens (Pearce et al., 2016), the deterioration of water facilities a few years after construction (Jimenez and Perez-Foguet, 2010), failure to repair water infrastructure due to capacity and funding problems at local levels (Mandara et al., 2013), vandalism of the water infrastructure (Deule, 2010; Kjellen, 2006; Pigeon, 2012), informal markets (Kjellen, 2000; Nganyanyuka et al., 2014), leakages in the water infrastructure (Daily News, 2013; The Citizen 2013), and the general mismanagement of the water sector in Tanzania, including the information management systems and donor influences (Georgiadou et al., 2011; Rottenberg, 2002).

Despite their undeniable contribution to the understanding the water sector in Tanzania and its problems, these studies have not taken into consideration the context in which such problems happen, e.g. the deeply rooted strategies of extraversion. It was for this reason that the present study examined accountability practices in the water sector in the context of governmentality.

\subsubsection{Alternative views to accountability practices: \\ 'from principal agent approach to collective action to informal accountability'}

Over the last two decades, the literature on accountability in Africa and Tanzania has mainly focused on the neo-liberal ideology expressed in good governance reforms. These reforms were prompted by international donors. Thus, the 'good governance rationale' has become a standard prescription for most African countries struggling with economic and political development (Grindle, 2010). In this context, good governance emphasizes accountability and transparency reforms - framed in the Principal-Agent (P-A) perspective - as a pre- condition for such countries to be given development aid (Andrews, 2013; Bana and Mc Court, 2006; Grindle, 2010; Hyden, 2013; Mukandala, 1998; Mutahaba, 2005; Neumayer, 2003; Tarling, 2005; Tilley, 2014).

Tanzania is not an exception in this regard. In fact, since the 1970s, Tanzania has attracted particular attention from the international donor community (Schlimmer and Provini, 2015:1). The country has been the biggest recipient of development assistance in sub- Saharan Africa (Edwards, 2014: 52-53, cited in Schlimmer and Provini, 2015:1). Scholars and development experts have dealt with this issue and have labelled Tanzania as a donor darling (Bigsten and Anders, 2001; Coulson, 1982; Edwards, 2014; Harrison et al., 2009; Hodler and Dreher, 2013; Lofchie, 2014, cited in Schlimmer and Provini, 2015:1) 
As a result, accountability reforms in African countries, including Tanzania, have been informed by the P-A perspective for decades. The P-A perspective represents one of the aspects of rationality with regards to how actors (national and international) think of accountability as a unidirectional phenomenon involving two actors in a formal setting: the principal and the agent. The principal is the account holder who has information about the actions and inactions of the agent, the 'accountor'. Based on such information, the principal is able to hold the agent to account. However, the framework also recognizes two problems that cause a conflict of interests between principals and agents: moral hazards, a problem that occurs when the interests of principal and the agent are not reconciled; and information asymmetry, which occurs when the agent has more information than the principal (Eisenhardt, 1989; Jain, 1998; Marquette and Peiffer, 2015; Rose-Ackerman, 1978). In this context, the P-A perspective assumes that once the interests of the principals and the agents are aligned then accountability can be strengthened (Marquette and Peiffer 2015).

However, there is an emergent consensus among scholars that principal-agent tailored thinking in accountability, as a good governance mantra, is not working (Andrews, 2010; Babeiya, 2011; Grindle, 2010; Khan and Gray, 2006; Ndumbaro and Heilman, 2002; Persson et al., 2013; Tilley, 2014). Part of the reason for this failure is that viewing accountability through a principal-agent lens emphasizes the rational choices of individuals that place them in discrete incidences (Marquette and Peiffer, 2015). For instance, on the problem of corruption accountability problem, Ndumbaro and Heilman (2002) have argued that while corruption is embedded in societal, economic and power relations in Tanzania, anti- corruption efforts (which are part of liberal accountability reforms) are based on the assumption that corruption is an individual act or personal misuse of public office for private gain. Thus, liberal accountability reforms become of limited value because they fail to take into account the social embeddedness of acts of corruption as opposed to the individual ones which support corruption in Tanzania (ibid). They conclude that the efforts to fight corruption based on liberal accountability thinking prevents real breakthroughs.

Recently the effort to improve accountability in African countries, has been gravitating towards the adoption of collective action perspectives to strengthen accountability (Persson et al., 2013) and more recently (but scantly) towards informal accountability (Carltz, 2013; Hyden, 2010; Lindberg, 2010; Kersall, 2008; Tilley, 2014; Walle, 2009). The collective action perspective focuses the role that intergroup trust can play in influencing individual decisions. Emphasis is usually put on the empowerment of citizens and civil society organizations initiatives through social accountability programmes (Stachz, 2014). Innovative use of ICT devices such as mobile phones is also increasingly regarded as part of collective action solutions for strengthening accountability and reducing corruption (Kroliwoski, 2014). However, this thinking is problematic; because the mobile telephone is a Technology (T) which presupposes western Type Rationality (R) and Mentality (M), but which is definitely out of sync with Africa-style accountability mentalities.

As a result, collective action is hampered by co-optation and a lack of supportive environment for the political participation of citizens. On the first challenge, collective action principals may be co-opted to serve the interests of government officials instead of those of their respective agents, i.e. donors or the society. The second challenge, which relates to the lack of supportive environment, provides limited space for the participation of citizens and their representatives to contribute to policies that affect their wellbeing. In fact 'the participation is weak and a matter of administrative courtesy and good will of senior officers in the policy making institutions' (Kiragu 
et al., 2009). Consequently, accountability reforms informed by both principal-agent and collective action theories are increasingly challenged and need to be re-examined.

On informal accountability, advocates of good governance and democracy tend to assume that when the behaviour of political actors is subject to formal accountability rules of conduct, intended policy goals will be achieved. However, recent research suggests that informal accountability mechanisms may structure the actor's incentives and formal accountability not only in complementary, accommodative ways, but frequently in competitive or substitutive ways (Helmke and Levitsky, 2004). Especially in weak institutional set-ups, informal accountability mechanisms may become compete with and substitute for formal accountability mechanisms.

This understanding is, for example, captured in the concept of clientelism (Hyden, 2010; Lindberg, 2009; Walle, 2009). Clientelistic relationships have three main characteristics: (i) they are between actors of unequal power and status; (ii) they are based on the principle of reciprocity i.e. a self-regulating form of interpersonal exchange, the maintenance of which depends on the return that each actor expects to obtain by rendering goods and services to each other and; (iii) they are particularistic and private, anchored only loosely in public law or community norms (Brinkerhoff et al., 2002; Kaufman, 1974; Lindberg, 2009; Walle, 2009).

Parliament-executive accountability relations at national and local levels are one important area where both formal and informal accountability mechanisms may structure the behaviour of Members of Parliament (MP) and executive officials at the national level and councillors and executive officials at the local level. For instance, a clientelistic relationship between an MP and constituents originate from the tendency to regard the office of MP as being infused with traditional notion of 'head of family' (Lindberg, 2009). In this informal accountability role, MPs are expected to take care of constituents by providing medical help, school fees, funeral costs, etc. This moral obligation of an MP is often felt very strongly (Lindberg, 2009). As a result, the traditional institution of 'family head' has been grafted onto MP's formal institution to produce a hybrid institution which may compel MPs to respond to demands for personalised accountability, which comes in the form of political clientelism (Lindberg, 2009). This phenomenon is also common among councillors and executive officials in local government settings.

As a result, accountability reforms are increasingly made to stop focusing on formal aspects of accountability, including the P-A RMTs, and instead consider informal accountability mechanisms more seriously (Helmke and Levitsky, 2004; Kersall, 2008; Lindberg, 2009; Tilley, 2014; Wit and Akinyoade, 2008). However, little is known about various guises of informal accountability and about how they interact with and relate to formal accountability. Many accountability studies in Tanzania have generally focused on political accountability at the local level (Hoffman, 2006; Lawson and Rakner, 2005; Maluka, 2011; Venugopal and Yilmaz, 2010) and the national level (Andrew, 2013; Carlitz 2013; De Mesquita and Smith, 2012; Grindle, 2010; Khan and Gray 2006; Hyden, 2010; Kersall, 2003; Kersall and Muya, 2004; Lawson and Rakner, 2005; Mallya, 2011; Matenge, 2012; Rioba, 2012; Tilley, 2014; Tsubura, 2014) and hardly on the water sector, particularly on the rural water supply sector. 
Those that have focused on the water sector are mostly found in grey literature ${ }^{2}$. Most of these studies show the structural and institutional failure of the accountability enforcing institutions in Tanzania as well as of the informal accountability practices. Although these works provide interesting insights that will help put my findings in context, they do not investigate both empirically and systematically informal accountability practices as an element of governmentality in the context of water supply in Tanzania.

This study, therefore, is an attempt to fill this gap by demonstrating empirically that the national and local government accountability practices (whether by default or design) in the government in general and in the water sector in particular are misconstrued. Accountability is always viewed by national government officials and international donors as a unidirectional phenomenon; they assume that, once formal accountability enforcing institutions are strengthened, service delivery (including water services) will improve. This dissertation departs from such studies by trying to understand accountability practices within a kind of governmentality, in which there is interplay of various and often conflicting formal and informal dynamics. These dynamics give rise to complex and self-contradictory biases, all of which make formal accountability practices difficult to achieve.

\subsection{The research questions}

In Tanzania accountability has become a presumed panacea to all policy problems, including problems related to water. When things are not moving in the right direction, it is common to hear the phrase that 'our leaders are not accountable', 'there is lack of accountability in the government'. These phrases expressing discontent with water service delivery are echoed by the recent data on water service delivery in Tanzania. For instance, a report released by the UNICEF and WHO in 2015 shows that Tanzania has not registered progress with regard to achieving the Millennium Development Goals (MDGs) of improving access to clean and safe water (UNICEF and WHO, 2015). Tanzania is ranked with less than $50 \%$ of its population using improved drinking water sources (ibid).

Thus, strengthening accountability practices at the national and local government levels is sought of by both government officials and international donors as a remedy to improve the delivery of public service, including water. At the national level, parliamentary accountability is a central theme on the international donor agenda and has received significant attention over the last decade. Parliament is the main forum for national accountability practices. Accountability relationships in this forum involve the executive officials and Members of Parliament. Members of Parliament have to navigate a double accountability problem: the horizontal accountability relationship to the executive, and the vertical relationship to the electorate. International donors' financial and technical assistance for parliamentary strengthening is anchored on the premise that effective democratic governance depends on a professional, accountable and responsive legislature (Mandelbaum, 2011:5). Despite the protracted assistance, little progress has been achieved in the accountability function of the parliament. This leads me to investigate why this is the case, and in particular examine how public officials at the national level are held to account.

\footnotetext{
${ }^{2}$ See the SNV Public Accountability in Tanzania (PATA) initiatives. The initiatives aims to explore new avenues to strengthen public accountability relationships towards better service delivery and a better business environment in Tanzania.
} 
Accountability practices in the water sector occur in a multi-level governance framework. This involves various actors, institutions, organisations and policies at the transnational, national, regional and local government levels. For example, in its water service delivery mandates, the Ministry of Water (MoW) works with national organisations, e.g. the parliament and the Prime Minister's Office, Regional Administration and Local Government (PMORALG), transnational organisations e.g. the Department for International Development (DFID), World Bank (WB), International Monetary Fund (IMF) etcetera, regional level organisations e.g. regional secretariat, Regional Administrative Secretary (RAS), Regional Water Advisor (RWA) and local government organisations e.g. district councils, District Water Engineer (DWE).

The investigation of the multi-level dynamics in the water sector focuses on accountability practices at the national, transnational, regional and local government levels. This may also be called 'intergovernmental accountability' practices. For instance, local government authorities render their accounts to the national level through the regional level, which is an extension of the central government. Equally, the central government has accountability relations with transnational actors, e.g. international donors. Although the multi-level dynamics in the current context of water service provision is anchored on a policy of decentralization by devolution (at least in theory) in which local governments are envisioned as autonomous entities, in practice, the central government refuses to give up its former powers. Meanwhile, the government of Tanzania is implementing a programme called "Big Results Now" (BRN) aimed at speeding up the implementation of government plans and policies. The programme covers six priority areas, including the water sector. However, one looming concern is how the BRN programme will work in a context of the existing centralization. This leads me to examine the challenges related to intergovernmental accountability practices between the MoW, regions and districts during the implementation of the BRN programme in the water sector.

Accountability relations in the local government authorities involve the executive officials and councillors. Councillors are political officials elected from wards. They have formal mandates from their electorates to conduct oversight on executive officials. On the other hand, executive officials are salaried and recruited based on their merits. However, the senior cadre of executive officials is appointed by either the Minister responsible for local governments or the President of the United Republic of Tanzania (URT) based on the Ministers recommendation. The executive officials at the local government level render their accounts to councillors in the district council, which is a formal forum for discussions and debates. This type of accountability relation has been at the heart of most of the literature focusing on formal accountability in Tanzania. However, little is known on the relationship between different types of informal accountability and, perhaps more importantly, the multiple relationships between formal and informal accountability in local government authorities. Thus, this leads me to investigate accountability relations between councillors and the executive officials in local governments. In particular, I examine whether councillors can hold the executives to account in the context of rural water supply.

Recently, information and communications technologies (ICTs) are increasingly seen as new avenues for citizens to hold service providers, including government officials to account (Edwards and McGee, 2016). But the key question invited by these technologies is whether citizens will be motivated to use the technology to hold public officials to account? Or whether public officials will be willing enough to accept information generated by ICTs and mobile phone technology in their daily Management Information Systems (MIS) routines. As a result, in the last decade, ICTs have increasingly become embedded in formal accountability practices in the water sector, 
including the idea that in case of broken-down water points, data may be more rapidly provided through ICTs which alert public officials to respond (Pearce et al., 2016). This means that the sustainability of existing water point infrastructure can be ensured, and accountability of public officials can be enhanced. This leads me to investigate whether public officials in the water sector are willing to respond to mobile phone generated information for improved rural water supply, and for strengthening accountability practices.

Based on the foregoing, this study answers five research questions: The first research question covers the main theme of the study. The other four research questions are specific. The first three of the specific questions are answered in the empirical chapters in the dissertation (Chapters five to seven), while the fourth question draws on findings across the empirical chapters. This question will be answered in chapter eight.

The broad research question is:

How are public officials held to account in the context of water supply in Tanzania?

In order to answer this question, I address the following four specific research questions:

I. How do MPs think of their own role of exacting accountability from the executive?

II. Can the councillors hold the executive (public officials) at the local level to account? If yes, how? If not, why?

III. Will ICT/mobile phone-induced accountability interventions be accepted by public officials in the MoW and local authorities as part of their Management Information Systems?

IV. What is the role of international donors in accountability practices in the context of water supply in Tanzania?

\subsection{Research design}

This study uses a mixed (qualitative and quantitative) case study design (Flyvjerb, 2006; Gerring, 2004; Thomas, 2011; Yin, 2003) to explore a phenomenon within its real life context. The case study research design is one of the principal means by which inquiry is conducted in the social sciences (Thomas, 2011:512). It is preferred here because it provides rich, detailed and in-depth information about cases that are studied (Berg, 2007). Moreover, it makes room for the use of multiple sources of data (Babbie, 1998). The mixed method case study design was used in this study because accountability relationships are complex, and involve various actors, power relations and socio-economic and political factors. 
Table 1: Data sources for this dissertation

\begin{tabular}{|l|l|l|}
\hline & Primary source & Secondary source \\
\hline Qualitative & $\begin{array}{l}\text { Interviews, participant } \\
\text { observations, } \\
\text { informal conversations }\end{array}$ & $\begin{array}{l}\text { Government documents, NGO } \\
\text { reports, WB reports, published } \\
\text { and unpublished articles, } \\
\text { newspapers, websites, blogs, } \\
\text { social media }\end{array}$ \\
\hline Mixed & $\begin{array}{l}\text { Complemented with semi- } \\
\text { structured interviews }\end{array}$ & $\begin{array}{l}\text { Government documents, NGO } \\
\text { reports, published and } \\
\text { unpublished articles, WB reports, } \\
\text { newspapers }\end{array}$ \\
\hline
\end{tabular}

The mixed research design of this study employed both qualitative and quantitative techniques of collecting data. Qualitative research normally seeks answers to questions by examining various social settings and individuals who inhabit the settings (ibid: 3 ).

This study was designed to ensure integrity, quality and transparency. The study followed all required research formalities, including obtaining research clearance from the University of Dar es Salaam. The research clearance was presented to various institutions where the research was to be conducted. They include: the national Parliament of Tanzania, the Ministry of Water and its departments and local government authorities. These institutions issued a letter confirming that the researcher had been permitted to hold interviews with the respective officials in the institutions. During the field work, the data collected were interpreted and presented in staffstudent seminars for discussion to ensure quality and transparency. The respondents were fully informed about the purpose and, methods of the study, about the intended use of the research findings as well as what their participation in this research entailed. They were asked to participate in the study voluntarily. All the information gathered from the respondents was treated with confidentiality.

However, designing a study of this magnitude is one thing, its effective undertaking in terms of data collection is quite another. Thus, I could not escape some limitations in the course of data collection. Sudden cancelation of interview appointments, long processes of obtaining research permits, bureaucracy in accessing senior government officials, travel challenges, official's reluctance to provide government documents because they were allegedly confidential materials were some of the major challenges I encountered in the course of gathering data. However, these challenges were overcome by my persistence and the use of informal networks to access respondents.

\subsection{Data collection methods}

The data presented in this dissertation were collected in three rounds of field work, which lasted from 2013 to 2015. In order to obtain the data presented in chapters four, five, six and seven, I used interviews, document reviews and participant observations. The interviews were held with political and administrative officials at the national (Parliament and the MoW) and local government levels and Civil Society Organisations (CSOs). Participant observations were made during council meeting proceedings at the local government level. Informal conversations were 
held in hotels, restaurants and bars. The review of documents covered government and nongovernment materials as well as published and unpublished articles about water and accountability practices in Tanzania. Quantitative and quantitative data were collected using the Q-method research which is described in detail in chapter five. Another set of semi-quantitative data was gathered with the help of Leximancer software (Katomero et al., 2013). This data set is reported in the concluding chapter to strengthen the main argument of the thesis. The data was also used to frame the main themes - the interactive dynamics of informal and formal accountability institutions and practices - of the thesis during its inception phase.

\subsubsection{Interviews}

I conducted interviews with political and administrative officials at the national and local government levels. A semi-structured interview guide, organized around the themes of accountability relationships, information collection analysis and usage, the Big Results Now (BRN) programme and ICT/mobile phone-driven accountability interventions as well as water service delivery in general, was used during the interviews (annex I). Following Denzin (1970:129), the interview themes were organized in such a way as to accurately convey meaning to the respondents and to motivate them to participate in the interviews.

I used a semi-structured interview method because of its potential to generate basic questions and themes as well as instantaneous follow-up questions for exploring any emerging issues in details as an interview went on. Likewise, the method was useful for generating data because it provided a good opportunity for the respondents to communicate their attitudes and opinions which, in turn, helped me to obtain accurate and reliable information.

However, this can only be achieved when respondents trust the researcher. Trust is key to the success of any interview. As recommended by Given (2008:811), building respondent trust helps to make respondents feel that the researcher has taken their interests into account. Thus, visiting officials in their respective work places for interviews enabled me to build trust and to access firsthand information on the research topic. It was also possible to get potential data in published form that would be difficult to obtain without first building rapport with the respondents. Trust goes hand in hand with respondent consent. I requested the respondents to allow me to record the interviews to facilitate accurate interpretation and analysis of the data. Each interview lasted approximately about one hour.

I held interviews with Members of Parliament, some public officials in the MoW, councillors and administrative officials in the rural water supply departments (at the village, ward and district levels) and Non-Governmental Organizations (NGOs). On various occasions, I held informal and formal discussions with the local councillors, administrative officials and officials working in Non-Governmental Organizations (NGOs). The discussions not only helped me to understand my respondents and obtain the needed information from them but also enabled me to develop good rapport with them to understand the respondent's everyday interactions and concerns in the context of management and accountability in supplying water to the people.

The interviews I held with Members of Parliament took place on Parliament grounds in Dodoma and in Dar es Salaam ${ }^{3}$. The interviews with the politicians, bureaucrats and some officials working in the NGOs at the local government level took place in four locations: (i) council meeting halls

\footnotetext{
${ }^{3}$ The interview process with Members of Parliament is expounded in detail in chapter four
} 
(ii) district, ward and village offices (iii) field sites and (iv) informal locations such as restaurants. A council meeting hall is a platform where politicians and bureaucrats meet to deliberate on development issues afflicting the council. I found it convenient to attend the meetings from which I selected respondents to interview. The benefit of this approach was twofold: it enabled me to do observations of the proceedings in the meeting while at the same time noticing potential respondents for interviews. I held interviews with the administrative staff in their respective offices. This strategy helped me to understand their working environment and build rapport with them.

Since most of the rural water projects are located in the villages, I found it convenient to travel along with the district administrative officials and politicians during some field-site inspection visits. This gave me an opportunity to observe the interaction between various actors involved in the management of water supply and to interview some of them. The informal locations that I visited included: local restaurants, bars and hotels. These places were the popular hotspots for district officials to eat lunch and drink, as well as hosting informal party meetings. They are "famous" settings where what is and will be happening in the council is discussed openly. I conducted informal interviews in these places with the politicians and administrative officials. This strategy helped me to obtain critical information that I would not have got had I conducted the interviews in formal settings. I also conducted interviews with the respondents during the SEMA mobile phone application testing. The Sensors, Empowerment and Accountability (SEMA) mobile application is an application designed to update the Water Point Mapping (WPM) system of the MoW on functionality/non-functionality of water points. I conducted the interviews immediately after the SEMA mobile application testing session came to an end. This approach was useful as it allowed the respondents to reflect on what was done during the session and provide their responses to the questions I asked them. The strategy also gave me an opportunity to meet with all the respondents, thus cutting down on travel costs and time.

At the MoW, I conducted interviews with public officials to address two key issues in relations to accountability practices: the Big Results Now (BRN) programme and the Water Point Mapping (WPM) system. The specific details of the programme and the system are presented in chapters six and seven, respectively. The interviews took place in the offices of the respective offices of public officials in the MoW. Senior administrative officials (well- educated and experienced in their fields) responsible for the management of the BRN and the WPM took me through various topical issues. The issues included: the rationale behind the introduction of the BRN programme and the WPM system, the reporting channels and information flow from the local governments, the regions and the MoW, the new institutional relationships (including accountability relationships) that emerged after the introduction of the BRN and the WPM in the regions and the districts. I also held interviews with some respondents during the SEMA mobile phone application testing at the MoW. At the regional level, I interviewed senior administrative staff responsible for rural water supply. The interviews were held in Mara region, which is located in north-west Tanzania. The interviews took place in the office of the Regional Water Advisor (RWA).

However, on the limitation side, it turned out that the research visits often coincided with the work schedule of the officials. Equally, there were frequent ad-hoc meetings that sometimes interfered with the interview schedules, thus necessitating cancellation of the interviews. These challenges were handled through observation of research ethics by letting the respondents fulfil their responsibilities first and hold the interviews when it was convenient for respondents to participate in them. 


\subsubsection{Participant observation}

Participant observation is a qualitative and interactive experience and relatively unstructured (Berg, 2006). The method makes it possible for a researcher to uncover the cognitive elements, rules and norms that underlie observable behaviour in a given social setting where a study is carried out.

Before embarking on data collection, I determined beforehand the type of information I would need to observe in the participant observation venues. I prepared a short list of things that would aid the observations. I observed four meetings: two in Bunda district and another two at the MoW. In Bunda district, the observations took place during council meetings which bring together councillors and bureaucrats to discuss development challenges afflicting the district, including water services. I observed council proceedings, district meetings and field-sites involving bureaucrats in wards and villages. I made similar observations during the introduction of the SEMA mobile phone application at a workshop that brought together councillors, ward officials, village officials and senior district administrative officials. At the MoW, I made similar observations during the introduction of the SEMA mobile phone application in workshops organized to solicit the views of MoW officials regarding using the application to update the WPM system.

\section{Table 2: Considerations for participant observation}

(Source: Inspired by Mack, et al., 2005, p. 20)

\begin{tabular}{|l|l|l|}
\hline Category & What I observed & Research focus \\
\hline $\begin{array}{l}\text { Verbal behaviour } \\
\text { and interactions in } \\
\begin{array}{l}\text { Bunda district and at } \\
\text { the MoW }\end{array}\end{array}$ & $\begin{array}{l}\text { Who speaks to whom and for } \\
\text { how long and for what } \\
\text { purpose; who initiates } \\
\text { interactions and what is the } \\
\text { tone of voice }\end{array}$ & $\begin{array}{l}\text { How participants use verbal } \\
\text { endowments to interact; personal } \\
\text { relationships and work-related } \\
\text { relationships }\end{array}$ \\
\hline $\begin{array}{l}\text { Physical behaviour } \\
\text { and gestures in } \\
\text { Bunda District and } \\
\text { the MoW }\end{array}$ & $\begin{array}{l}\text { What participants do; who } \\
\text { interact with whom and why; } \\
\text { who does what; who is not } \\
\text { interacting and why; }\end{array}$ & $\begin{array}{l}\text { How participants use their bodies } \\
\text { and voices to communicate } \\
\text { different emotions. How does their } \\
\text { behavior indicate their feelings } \\
\text { towards one another, their feeling } \\
\text { during discussions in the formal } \\
\text { meetings; their social rank or } \\
\text { profession }\end{array}$ \\
\hline $\begin{array}{l}\text { Participants who } \\
\text { stand out in Bunda } \\
\text { District and the } \\
\text { MoW }\end{array}$ & $\begin{array}{l}\text { Identifying participants who } \\
\text { receive a lot of attention from } \\
\text { others }\end{array}$ & $\begin{array}{l}\text { Resourceful participants to } \\
\text { approach and hold informal } \\
\text { interview with as key respondents }\end{array}$ \\
\hline
\end{tabular}




\begin{tabular}{|c|c|c|}
\hline $\begin{array}{l}\text { Attitudes towards } \\
\text { council meetings and } \\
\text { the newly introduced } \\
\text { technology in Bunda } \\
\text { district and at the } \\
\text { MoW }\end{array}$ & $\begin{array}{l}\text { Understanding how council } \\
\text { meetings are conducted; } \\
\text { How participants interact } \\
\text { during council meetings; how } \\
\text { party politics affects council } \\
\text { proceedings; does the } \\
\text { technology draw participant } \\
\text { attention; participants } \\
\text { reaction to the technology; } \\
\text { do they like it; do they reject } \\
\text { it; reasons for embracing or } \\
\text { rejecting the technology; }\end{array}$ & $\begin{array}{l}\text { What is their attitudes indicates } \\
\text { about their feelings about council } \\
\text { meeting proceedings; } \\
\text { what their attitude indicates about } \\
\text { their feelings about the proposed } \\
\text { technology both in Bunda district } \\
\text { and the MoW }\end{array}$ \\
\hline $\begin{array}{l}\text { Power relationships } \\
\text { in Bunda district and } \\
\text { at the MoW }\end{array}$ & $\begin{array}{l}\text { who has power over whom; } \\
\text { who has power over what; } \\
\text { when does one have power; } \\
\text { what is the source of power }\end{array}$ & $\begin{array}{l}\text { Accountability relationships among } \\
\text { participants }\end{array}$ \\
\hline
\end{tabular}

While at the workshops, I focused on building rapport with the participants so that they could trust and accept me. This approach helped me familiarize easily with the responds and observe and learn about their behaviour in the normal course of their work. I spent sufficient time interacting with the respondents to get the needed data. As Bernard (2006) correctly argues, 'the informal, embedded nature of participant observation means that the observer must always just delve straight into all the topics that address the research issues and then leave'. Overall, the participant observation method was useful in collecting the data because social practices such as personal rituals and routine are sometimes missed or hard to uncover in conventional interviews, for respondents may not mention them or may consider it silly to talk about them (Benard, 2006).

\subsubsection{Sampling}

The term sampling refers to a process of selecting a convenient but representative sample from a population. It transcends research in general and research paradigms in particular (Onwuegbuzie and Leech, 2007:105). The way sampling is treated varies in qualitative and quantitative researches. For instance, in quantitative research, the goal is to obtain large, representative samples and to generalize findings to entire populations (Onwuegbuzie and Leech, 2007). However, this is not the case with qualitative research; where purposive sampling of one or a few cases (i.e., individuals, groups) is more appropriate (Onwuegbuzie and Daniel, 2003, cited in Onwuegbuzie and Leech, 2007:106). Thus, using purposive sampling signifies that a researcher sees sampling as a series of strategic choices about with whom, where, and how one does one's research. This means that a sampling technique must be tied to the research objectives (ibid).

Based on the foregoing, I used purposive and snowballing techniques to select the respondents. The respondents from the Parliament of the United Republic of Tanzania were selected based on the themes identified in the Q-method. Other criteria included age, gender, type of political party with which one is affiliated (i.e. the ruling party or one of the opposition parties), rural- urban divide; first-term vis-à-vis second- and third-term Members of Parliament and special seats vis-àvis elected $\mathrm{MPs}^{4}$. The respondents from the district level were selected based on their knowledge

\footnotetext{
${ }^{4}$ Chapter five describes in detail the criteria used to sample the Members of Parliament
} 
of rural water supply and the position each held, i.e. a political or administrative position. The respondents from the MoW were selected based on their knowledge of water service provision, including the Water Point Mapping (WPM) system and the BRN initiative, as well as on the basis of the position each held. At the MoW, officials from the departments of urban water supply, rural water supply and water resources management were purposively sampled.

Table 3: Classification of respondents

\begin{tabular}{|l|c|}
\hline Interviewed respondents & No. of interviewees \\
\hline Members Parliament & 35 \\
\hline Senior administrative officials in Bunda district & 10 \\
\hline Senior political officials in Bunda district & 2 \\
\hline Officials responsible for rural water supply in Bunda district & 10 \\
\hline Ward administrative officials in Bunda district & 8 \\
\hline Village administrative officials & 8 \\
\hline Councillors in Bunda district & 16 \\
\hline Project contractors and consultants & 4 \\
\hline Officials working in NGOs & 2 \\
\hline Senior officials in the MoW (BRN) & 3 \\
\hline Senior officials in the department of rural water supply, MoW & 3 \\
\hline Officials in the ICT department, MoW & 3 \\
\hline Regional administrative water officials in Mara region & 2 \\
\hline Total & 106 \\
\hline
\end{tabular}

The snowball technique was used to obtain other respondents with knowledge of the research topic recommended by their fellow respondents. This technique helped to save the time of identifying respondents to be interviewed, but also to build trust among the respondents suggested by their colleagues. Explaining that I got to know them through their colleagues made them confident to communicate clearly their attitudes and opinions about the questions I asked them. Using this sampling technique, I obtained a total of 106 interviewees who constituted the sample.

\subsubsection{Document reviews}

Documentary review provides one with an opportunity to engage with the literature that has already been produced for other purposes. The document review process reported here involved the review of studies that had been previously collected by various organizations and individuals. They included both published and unpublished materials by researchers, government agencies and NGOs. The process of reviewing them was done systematically by identifying, analysing and deriving useful information from them. A list of characteristics or attributes was developed to ensure effective review of the documents. For instance, I made sure that key documents that cover the water sector in Tanzania were included on the list. Likewise, documents that cover ICT and accountability issues were included on the list.

The documents were selected based on their relevance to the research questions. The review of the documents focused on district and regional statistics and figures on rural water supply provided by regional and district officials, rural water projects, legal, regulatory and policy frameworks guiding the rural water supply sector, BRN and WPM documents produced by the MoW, ICT projects in the water sector in Tanzania as well as on accountability practices in the water sector. 
A total of fifty documents, including policy documents, evaluation reports, strategy documents, published and unpublished articles, and NGO and donor reports, were reviewed (Annex 1). This was useful in strengthening and triangulating the information obtained from the interviews.

\subsection{Data analysis}

The analysis of qualitative data is not completely straightforward or cut and dried. It is rather an organized and systematic process of breaking down chunks of data and turning the pieces into meaningful information. Thus, the most common way to analyse interview data is content analysis (Berg, 2001). I analysed the data presented in this study in two stages. The first stage involved the analysis of documents in order to be able to construct better, informed interviews; in the second stage I analysed the interview data. In order to strengthen the reliability of the data, the results obtained from the analysis of the interview data were supplemented with the results from the analysis of the data from the documents. I analysed the interview data following Berg, (2001) systematic stages of analysing qualitative data. The stages consist of three concurrent flows of action: data reduction, display and verification. In the data reduction stage, I arranged the data in a logical way by placing relevant interview material in a file system, which helped me develop a means by which to access various aspects of the data easily.

In performing this task, I used computer aided software called ATLAS.ti. The software was useful at this stage because it allowed me to manage, shape and make sense of structured and unstructured information. Usually, this makes it possible to generate themes, patterns and quotes emerging from the data. It also provides a sophisticated workspace that allows one to process information effectively and efficiently by classifying, sorting and arranging data ${ }^{5}$. The data analysed using ATLAS.ti software include interviews (stored in audio, video or written form) and documents. In the work space area of the software, I used the Hermeneutic Unit (HU), which serves as the main editing tool and which provides access to all other tools for data analysis. The main menu of the software provided access to different components of the Hermeneutic Unit, i.e. documents, quotations, codes, etc. After all the interviews and document materials had been put on the ATLAS.ti software, I used an open coding strategy to assign codes to themes, quotes and patterns of the information that appeared to be relevant both to the research topic and the questions.

The second stage in the coding process involved applying a closed coding strategy to reduce the initial number of codes into a manageable number of codes to discern meaningful information. In chapter six, I present the analysis of the collected data using a narrative data analysis approach. This is one of the approaches in the tool kit of qualitative data analysis used to analyse "natural language data'. It is based on the analysis of how people describe or account for events, real or imagined; it is often referred to as the telling of stories (Easterby et al., 2009:182).

Using the narrative data analysis, the interview data were coded to generate themes and concepts. The process was done through ATLAS.ti software, which was used to generate themes, patterns and quotes, which were later interpreted so as to produce meaningful patterns of information. The initial 20 codes, which corresponded to my decision to summarize them, were reduced to 10-15 and finally to 5-7 overarching themes. The themes include: kinship bonds, clientelism, rent-

\footnotetext{
${ }^{5}$ http://atlasti.com/qualitative-research-software/
} 
seeking, political interference, loans as a political predicament, party caucus, and central-local government relations. In the fourth stage, the interview quotes were arranged into themes to identify the main ideas that make up the theme and sub-themes so as to examine evidence of relationships between overarching themes.

A similar process was repeated in the analysis of data presented in chapters seven. In chapter eight, the initial codes generated were eight, i.e. the SEMA mobile phone application as an administrative tool, the use of the application to demand accountability from the local governments, internal bureaucratic conflicts over the Water Point Mapping (WPM) system, information on new and 'not old' water projects reported via the SEMA mobile phone application, legal conflicts over an ideal reporter of the functioning/non-functioning of rural water points, fights over resources provided by international donors through the WPM system, conflicts over who should receive information via the SEMA mobile phone application as well as informal reporting channels. The next step involved reducing the number of codes further so that conclusions could be reached and overarching themes could be obtained from them. The closed coding technique was applied to reduce the number of codes from eight to six overarching themes. Thus, the final list of codes included internal bureaucratic politics on the WPM system, the use of SEMA mobile phone programme to demand accountability from local governments, favouring information on new water projects reported via the SEMA mobile phone application, informal information reporting channels as well as conflicts over who should report information on the SEMA reporting platform and over who should receive information. The final step in this stage involved putting themes into interview quotes to identify the main ideas that make up the theme and sub-themes so as to examine evidence for relationships between overarching themes.

\subsection{Structure of the dissertation}

This dissertation is organized into eight chapters. The second chapter presents governmentality as the overall theoretical framework used in this study. In the same chapter, the concept of accountability is thoroughly discussed and understood in the context of governmentality theory.

The third chapter provides historical context on accountability practices in Tanzania. Drawing theoretical notions from the governmentality theory, the chapter analyses the historical context of accountability practices during the pre-colonial, colonial and post-colonial periods.

Chapter four examines the current accountability practices and institutional designs. The chapter also examines various rationalities, mentalities and technologies ascribed into the concept of water as well as different institutional designs for water provision in Tanzania. The current national and local government accountability structures are also analysed.

Chapter five focuses on accountability practices at the national level. Parliament, which is the forum at the epicentre of a democratic political system, is the main focus in that chapter. In particular, the chapter answers the question regarding how MPs think of their own role of exacting accountability from the executive.

Chapter six investigates the accountability relationships between councillors and executive officials in the context of rural water supply by posing the question whether councillors can hold such officials to account. 
Chapter seven investigates the potential of enlisting the use of ICTs/Mobile phone-induced accountability interventions in the water sector for improved accountability and water service delivery.

Chapter eight answers the research questions and summarises the main findings of the study. The chapter also tentatively deals with possible implications of this study for the going with or against the grain debate on governance reforms in Tanzania. It is shown how the governmentality approach may clarify the dilemmas in this political debate 


\section{Accountability as an element of governmentality: conceptual and theoretical frameworks}

There has been a persistent call to make governments and public officials accountable, particularly in the developing world. This has brought about disagreements on what constitutes accountability in government, i.e. demanding, rendering, assessing, and responding to accounts (Olsen, 2015). The disagreements are partly the result of the fact that accountability is an essentially contested political notion; indeed, it is an umbrella concept consisting of almost all facets and aspects of the drive for 'democracy' and 'good governance'. In this chapter, the concept of accountability, including its various theoretical parameters, is interpreted within a governmentality framework.

\subsection{Governmentality: theoretical framework}

This study uses governmentality as the overall theoretical framework to illuminate accountability RMTs at the national and local levels of governance in Tanzania, in the water sector in particular. The decision to use governmentality as the main theoretical framework is based on the fact that the theory provides essential ideas and a richer framework than principal- agent tailored approaches for analysing accountability as a socially embedded practice interwoven with the fabric of society-government relations. In addition, the theory can be used to analyse political power, including accountability beyond the formal settings, i.e. forms of power that include nonpolitical sites like the family institutions (Lemke, 2007).

The term 'governmentality' was introduced by Michel Foucault in the 1970s when analysing the notion of political power (Rose at al., 2006). For Foucault, governmentality is characterized by a relational understanding of power. It bundles all aspects or dimensions of power - power- over (domination), power-to (capacity, emancipation) and power-with (collective action, alliance building) - in one concept. While Lukes' (1974) better known three dimensional-view of power power as coercion, power as agenda control, power as 'mind control' - offers interesting insights for understanding power in a political system, it is not without weaknesses. The main weakness, according to Haugaard, (2015: 2), is that it reinforces the one-sided, normatively reprehensible power-over view of power. Thus, an alternative view of power is provided by Foucault, (2000a) through his account of power as 'subjectification'.

Subjectification is understood as a form of power which makes individuals subjects (Foucault, 1982: 781; 2000a). For Foucault, the meaning of the word subject is twofold: first, being subjected to someone else by control and dependence; and, second, tied to his own identity by a conscience or self-knowledge (Foucault, 1990; 1993; 2000a). Taken together, both meanings constitute a form of power which subjugates and simultaneously makes subject to. Subjectification directly affects everyday life which 'categorizes the individual, marks him by his own individuality, attaches him to his own identity, imposes a law of truth on him which he must recognize and which others have to recognize in him' (Foucault, 1982). Notably, Foucault's view of disciplinary power as subjectification lends itself to "positive injunctions about the empirical nature of power, rather than as a normative evaluation arguing that power is positive in the sense of constituting reality, as opposed to being prohibitive' (Haugaard, 2015: 2).

The dimensions of power are not simply different forms of power but constitute different aspects of political interaction in a political system (Haugaard, 2015: 3). They are normatively open or ambivalent. On the one hand, they create the conditions for political stability in systems of modern 
justice and democratic practices; on the other hand, they open up possibilities for reprehensible modes of domination. (Haugaard, 2015: 1-2). For instance, as Haugaard argues: '(t)he structural reproduction of concerted power has to deliver the real potential for electoral, victory at a future date, not simply in principle, but in practice. It is for this reason that in permanently divided societies with first past the post electoral systems, where majorities take all, tend toward instability. While the system appears fair in principle, in practice these structures do not give real possibilities of power for the minority' (Haugaard, 2015:10). Thus, power is not conceived as a stable and fixed entity that could be "stored" at particular institutional sites, but signifies the result of a mobile and flexible interactional and associational network (Walters, 2004: 31-33 cited in Lemke, 2007: 9). In that case, each power dimension has the potential for either domination or emancipation (Haugaard, 2015: 4). Therefore, the concept of governmentality is inextricably linked with power.

In a broad sense, the term governmentality was understood by Foucault as a conglomeration of techniques and procedures for directing human behaviour i.e. the government of children, of souls and consciences, of government, of a household, of a state, or of oneself (Foucault, 1997: 82). Thus, in governmentality, government is defined as 'conduct of the conduct' (Foucault, 1982: 220-221). Understanding what government is in Foucauldian sense would then require understanding what the term 'conduct' means.

To 'conduct', as noted by Dean (2010), means to lead, to direct or to guide, and possibly to figure out how this should be done. However, the ethical or moral sense of the word starts to appear when one considers the reflexive meaning as in 'to conduct oneself' (Dean 2010: 21). Here, one pays attention to the form of self-direction appropriate to certain environments or situations, e.g. at work and at home, in business dealings, in relation to clients or friends (ibid). If the word 'conduct' is treated as a noun it would refer to expectations on one's behaviours, actions and even comportment, i.e. the articulated set of behaviours (Dean, 2010). This would mean a code of conduct by which actual behaviour can be judged, and which serves as an ideal after which individuals and groups should strive (ibid). This line of thinking would also mean that it is possible to regulate and control behaviour rationally in a quest to make it predictable.

Therefore, considering these notions of 'conduct' together, government would mean any attempt to shape, with some degree of deliberation, aspects of human behaviour according to a particular set of norms and purposes (Dean, 2010). Thus, to Foucault 'government is an activity that undertakes to conduct individuals throughout their lives by placing them under the authority of a guide for what they do and for what happens to them' (Foucault 1997:68). In this context government may be understood as an organization/entity with power and authority whereby it attempts to deliberate on and to direct human conduct (Dean, 2010). From the point of view of those who seek to govern, human conduct is understood as something that can be regulated, controlled, shaped and turned to specific ends (ibid). Thus, 'disciplinary' power as connecting 'disciplining citizens from above by the state' and 'self-discipline by citizens themselves', makes it possible to analyse accountability practices as interface between the personal (which is always informal) and the social/collective (which can be both formal and informal). Disciplining from above would be ineffective if it did not strike important 'chords' in the self-disciplining from below. In performing such a two-level analysis of 'governmentality-as-power', it becomes possible to distinguish elements of governmentalities as R-M-Ts. 
As an analytical perspective, governmentality raises questions about the phenomenon that it intends to understand through empirical inquiry (Rose et al., 2006). Therefore, there are three main elements of governmentality which are used to illuminate a wide range of governing practices, namely: Rationalities, Mentalities and Technologies (R-M-Ts). These elements are significant in this study because they provide essential ideas and a richer framework for analysing accountability practices in Tanzania.

\subsubsection{Rationalities of governing}

In governmentality, rationality means ways of thinking in a fairly systematic manner, of making calculations, and of defining purposes and employing knowledge (Dean, 2010: 19). It is a formal reflexive thought articulated in academic disciplines, e.g. theories of racist supremacy found in psychology and sociology disciplines. In contemporary liberal polities, the rationalities are often derived from the human sciences, i.e. psychology, political science, sociology, economics, management or medicine (ibid). Thus, thought remains 'rationalistic' to the extent that it privileges systematic ways of thinking over symbolic, mythic or poetic modes (Dean, 2010: 19).

Rationalities of government specify the distribution of tasks and actions between authorities and articulate ideals or principles that should direct government (Lovbrand et al., 2009). Thus, governmentality entails particular ways of thinking about governing with different rationalities (Miller and Rose, 1990; Rose and Miller, 1992 cited in Dean 2010: 24). The ways in which we think about governing are many and heterogeneous, involving different types of agency and authority and employing different types of thought (Dean, 2010: 27). The central idea is how thought operates within organized ways of doing things and regimes of practices (Foucault, 1991b cited in Dean 2010: 27) as well as how it is embedded in programmes for the direction and reform of conduct (Dean, 2010: 27). Governmentality is also concerned with the analysis of thought as it is linked to and embedded in technical means for shaping and reshaping conduct and institutions (ibid).

\subsubsection{Mentalities of governing}

The notion of mentality involves unreflexive, cultural knowledges, to which we are linked. It entails the idea that thinking is a collective activity (Dean, 2010). And it is a matter, not of the representation of individual mind or consciousness, but of the bodies of knowledge, beliefs and opinions in which we are immersed (Dean, 2010: 27). The bodies of knowledge, in this case, are not formal rationalistic 'bodies of knowledge', but what phenomenologists like Schutz have called uncodified or tacit 'stocks of knowledge'. Actually, codified 'bodies of knowledge' are one of the many possible 'stocks of knowledge'. For example mentalities which are associated with one being a slave or a servant without questioning one's position in life. It is a collective, relatively bounded unit, and is not readily examined by those who inhabit it. Thus, a mentality might be described as a condition of a web of 'understandings' and volitions and feelings and thus it cannot easily be understood from within its own perspective (ibid).

The idea of mentalities of governing emphasizes the way in which the 'thinking involved in practices of government is implicit and embedded in language and other technical instruments and not usually open to questioning by its practitioners' (Dean, 2010: 27). This means that the way we think about exercising authority draws upon the expertise, vocabulary, theories, ideas, philosophies and other forms of knowledge that are available to us (Dean, 2010: 27). Mentalities 
may originate from society's culture, values and norms as well as the socio-cultural and political influences of international organizations and institutions.

\subsubsection{Technologies of governing}

Technologies and practices are important elements of governmentality. They refer to a complex system of practical mechanisms, procedures, instruments and calculations through which authorities seek to guide and shape the conduct and decisions of others in order to achieve specific objectives (Lemke 2007: 9). Technologies can also be interpreted as materialized knowledge or techniques which can be formal or informal and which are used to achieve specific goals.

The technologies of governing are numerous and reflective of countries' social-cultural, economic and political orientations. They include, but are not limited to: 'methods of examination and evaluation; techniques of notation, numeration, and calculation; accounting procedures; routines for the timing and spacing of activities in specific locations; presentational forms such as tables and graphs; formulas for the organization of work; standardized tactics for the training and implantation of habits; pedagogic, therapeutic, and punitive techniques of reformulation and cure; architectural forms in which interventions take place (i.e. classrooms and prisons); and professional vocabularies' (Inda, 2005: 9; Miller and Rose, 1990: 8; Rose and Miller, 1992: 183, cited in Lemke 2007: 9). For example whips, prison sentences, types of punishments or rewards etcetera are instances of technologies seeking to guide and shape the conduct and decisions of others in a quest to achieve specific objectives.

Foucault explained three different forms of technology in his work: technologies seeking to discipline the individual body or to regulate population processes, technologies of the self, and political technologies of individuals (Foucault, 1988; 2000b). The first two concentrate on processes of self-guidance and the ways in which subjects relate to themselves as ethical beings (ibid). The third one denotes 'the way by which we have been led to recognize ourselves as a society, as a part of a social entity, as a part of a nation or a state' (Foucault, 2000b: 404, cited in Lemke, 2007: 8). Overall, the concept of technologies of governing includes not only material but also symbolic devices. It follows then that discourses, narratives and regimes of representation are not reduced to pure semiotic propositions; instead, they are regarded as performative practices (Lemke, 2007: 9). By focusing on diverse and distinct technologies, it becomes possible to understand the processes of individualization and practices of institutionalization as technologies of government (Lemke, 2007: 8). This approach makes it possible to ask questions about the relationships between different governmental technologies. For example, one can investigate how technologies of the self and political government are articulated with each other (Foucault 1988; 1993: 203, cited in Lemke, 2007: 8). The difference between rationalities of government and technologies is in the fact that rationalities of government render reality into the domain of thought, and technologies of government translate thought into the domain of materiality (Miller and Rose, 2008, cited in Lovbrand et al., 2009). 
Table 4: Conceptual summary of elements of governmentality

\begin{tabular}{|l|l|l|}
\hline Meaning & Example \\
\hline $\boldsymbol{R}$ & $\begin{array}{l}\text { Ways of thinking in a fairly systematic } \\
\text { manner, of making calculations, and of } \\
\text { defining purposes and employing } \\
\text { knowledge }\end{array}$ & $\begin{array}{l}\text { E.g. principal-agent and collective } \\
\text { action theories of accountability } \\
\text { found in political science and } \\
\text { public administration disciplines }\end{array}$ \\
\hline $\boldsymbol{M}$ & $\begin{array}{l}\text { Unreflexive, cultural knowledges, to } \\
\text { which we are linked. It entails the idea } \\
\text { that thinking is a collective activity }\end{array}$ & $\begin{array}{l}\text { E.g. mentalities which are } \\
\text { associated with one being a slave or } \\
\text { a servant without questioning one's } \\
\text { position in life }\end{array}$ \\
\hline $\begin{array}{l}\text { Complex system of practical } \\
\text { mechanisms, procedures, instruments } \\
\text { and calculations through which } \\
\text { authorities seek to guide and shape the } \\
\text { conduct and decisions of others in order } \\
\text { to achieve specific objectives }\end{array}$ & $\begin{array}{l}\text { E.g. whips, prison sentences, types } \\
\text { of punishments or rewards etcetera, } \\
\text { seeking to guide and shape the } \\
\text { conduct and decisions of others in a } \\
\text { quest to achieve specific objectives. }\end{array}$ \\
\hline $\begin{array}{l}\text { The underlying assumption in this context is that the mobile telephone is a T, which } \\
\text { presupposes } \\
\text { accountability }\end{array}$
\end{tabular}

Based on the foregoing, I use governmentality in this study to understand accountability practices at the transnational, national, and local government level in Tanzania. However, it is important to understand first the various meanings of the concept of accountability so as to iron out the inherent R-M-Ts.

\subsection{Conceptual overview of accountability}

With a long tradition in both political science and financial accounting, accountability has evolved to become a ubiquitous concept, attracting all sorts of labels which indicates its problems as well as its significance, both normative and descriptive (Bovens, 2010). Out of this cacophony, which is the result of accountability's semantic confusion, accountability has been labelled a chameleon concept (Sinclair, 1996), a slippery concept (Brandsma, 2010) and a multiple concept (Schliemann and Bovens, 2010). Overall, Dubnick and Justice (2004) says that accountability is a conceptually and empirically slippery word, subject to a host of competing definitions, interpretations, understandings and rhetorical usages.

Yet, accountability is the hallmark of modern democracy Dubnick (2005) and remains one of those 'golden concepts' whose impact on policy discourses is indisputable (Schliemann, 2008). For instance, all major prescriptions on policy failures, including corruption problems, arguably centre on strengthening accountability enforcing institutions in a developing country context.

Recently, international pressure to make governments more accountable has been centred on defining accountability from a formal perspective (Tilley, 2014). Here, accountability denotes a relationship between a bearer of a right or a legitimate claim and the agents or agencies responsible 
for fulfilling or respecting that right (Rakner and Lawson, 2005: 9). Accountability in this formal sense means a two-way relationship of power; the duty to be accountable in return for the delegation of a task, a power or a resource (Bovens, 1998; Bovens, 2007; Mulgan, 2003). This principal-agent view of accountability has for a long time substantially informed many reform undertakings (Babeiya, 2011; Fjeldstad, 2003; Heilman and Ndumbaro, 2002; Stchatz, 2013; Tilley, 2014; Wit and Akinyoade, 2008).

Classical liberal scholars in the political science tradition such as John Locke conceived accountability as a complex structure of checks and balances used to prevent abuse of power (Cendon, unpublished). This Lockean thinking pioneered the birth of liberal democracy, built on the principle that governments should be formed by democratically elected representatives who will become accountable to citizens, through an elaborate legal and institutional framework, when in power (Borowiak, 2007).

In the accounting field, accountability was conceived in terms of financial prudence and the rendering of financial accounts in accordance with regulations and instructions (Barton, 2006; Normanton, 1966, cited in Lindberg, 2009). In this context, the concept of accountability is considered equivalent to a financial and performance audit which provides information on the outcomes emanating from policy goals (Borowiak, 2007). However, the principle of delegating some authority, evaluating performance and imposing sanctions reflects the basic tenets of an accounting practice just like it does in the political science tradition (Lindberg, 2009).

Despite its rich history, accountability has become a normatively indispensable but politically and intellectually contested concept (Borowiak, 2007). One serious area of contestation, as noted earlier, has to do with the meaning of the concept. For instance, the stretching of the concept to include everything has resulted in its eventual ambiguity, semantic confusion and vagueness (Lindberg, 2009). In an attempt to remedy this, most studies on accountability propose the classifications of the various types of responsibility and accountability, according to different domains of accountability (Borowiak, 2007), for instance, administrative, legal, political, professional and moral accountability; hierarchical, legal, professional and political accountability; personal, social, professional and civic responsibility; parliamentary control, managerial accountability, judicial and quasi-judicial review, constituency relations and market accountability (Borowiak, 2007; Cendon 2000, unpublished). Despite the attempt, to classify accountability according to different domains, there is the problem of indeterminacy in the classification of the concept.

Dubnick and Justice (2004:11) suggest that accountability can be rendered meaningful if it is approached in at least six interrelated contexts. The first context is within a cultural mentality. Here, accountability is viewed as a reflection of legitimized certainties within a community, i.e. certainties that accompany beliefs about how the world in terms of social relationships and causality is organized. Thus hierarchical cultures generate one form of accountability, whereas egalitarianism produces another. The second context is within institutional rationality. In this context, accountability is conceived in terms of rules, norms and grammars through which authority is controlled in order to make it appropriately exercised. The third context encompasses social transactions in which accountability is viewed as a way for individuals to relate to one another, i.e. an ongoing process of account-giving, excuse-making and account taking, all aimed at developing and maintaining trust. The forth context has to do with organizational technology. In this context, accountability is interpreted as the enactment of formal and informal mechanisms 
for dealing with expectations and uncertainty. Social psychological rationality, the fifth context, views accountability as a means by which we construct ourselves and develop identities that are eventually applied in other frames of reference, for example, identifying ourselves as siblings, citizens, workers, etc. Finally, in complex task environments of multiple diverse and conflicting expectations, accountability is conceived as a means for managing complexities (ibid).

The emphasis in this study is on embedding accountability practices in the context of governmentality by analysing accountability practices as interface between the personal (which is always informal) and the social/collective (which can be both formal and informal). However, The organizational R-M-Ts of accountability in which accountability is interpreted as the enactment of formal and informal mechanisms for dealing with expectations and uncertainty as argued by Dubnick and Justice (2004), and accountability as a principle for organizing relations between the ruled and rulers and making government officials accountable as explained by Olsen (2015: 426) are considered in this study as a starting point for such analyses.

Stephan Lindberg proposes five defining features of any type of formal accountability: (i) An agent or institution who is to give an account (A for agent); (ii) an area, responsibilities, or domain subject to accountability (D for domain); (iii) an agent or institution to whom A is to give account ( $\mathrm{P}$ for principal); (iv)the right of $\mathrm{P}$ to require $\mathrm{A}$ to inform and explain/justify decisions with regard to $\mathrm{D}$; and (v) and the right of $\mathrm{P}$ to sanction $\mathrm{A}$ if $\mathrm{A}$ fails to inform and/or explain/justify decisions with regard to D (Lindberg, 2009: 8). In this context, accountability is viewed as a practice involving establishing facts and assigning causality and responsibility; formulating and applying normative standards to assess conduct and reasons given and building and applying capabilities to sanction inappropriate conduct (Olsen, 2015). This view is consonant with Boven's (2007) actor-forum accountability relationship model where accountability is viewed as a social relationship between an actor and a forum, in which the actor is obliged to explain and justify his/her conduct, after which the forum may pose questions and pass judgment. Finally, the actor faces certain consequences of his conduct (Figure 1).

Figure 1: Actor-forum accountability relationship

(Source: Inspired by Bovens, 2007 and Willems, 2010)

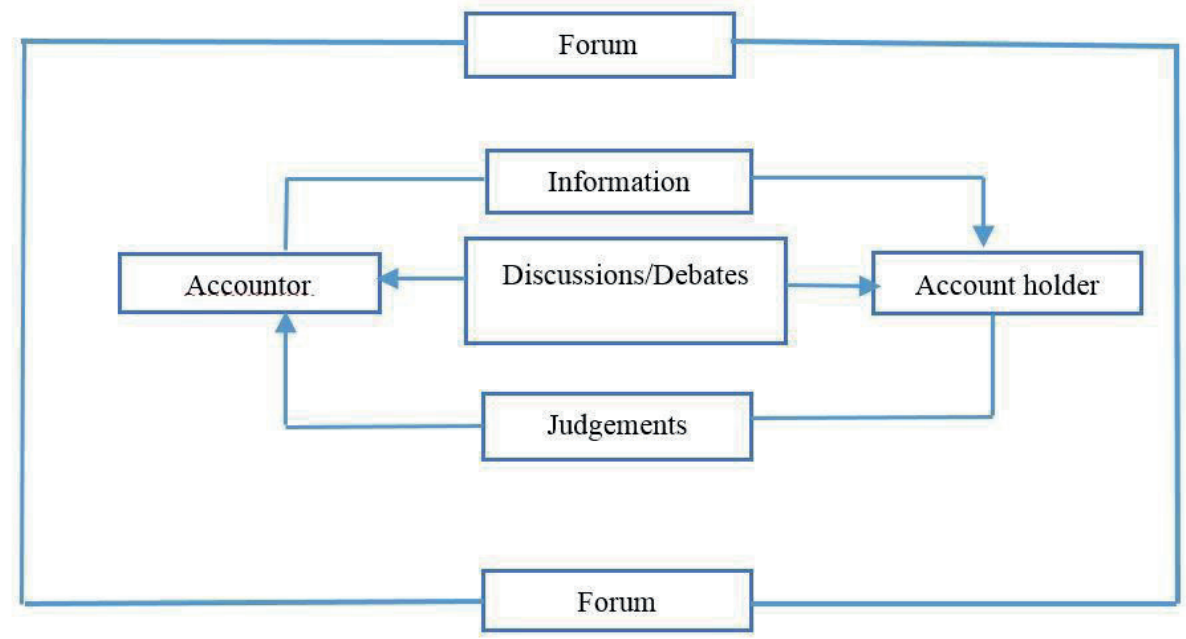


When performance standards are met by the accountor, intrinsic and extrinsic forms of rewards are usually given, e.g. promotion, an increase of one's salary, recognition for excellent work, etcetera. The opposite would attract demotion or transfer, depending on the extent to which one has violated prescribed formal rules. This is technically called formal judgment (Figure 3). Equally, in some circumstances, informal judgment may be passed on poor performance. This may include exclusion of an individual from an administrative network. Informal positive judgments can include access to informal networks for obtaining resources. Schedler (1999) asserts that there are two forms of accountability: answerability, the obligation of public officials to inform people about and to explain to them what they are doing, and enforcement; the capacity of accounting agencies to impose sanctions on power holders who have abdicated their public duties.

However, Lindberg (2009) has argued that although defining accountability in Schedler's formulation may seem to capture the core of the concept, accountability relationships between the principal and the agent, or rather the accountor and the account holder (in Boven's perspective) may be partly or wholly, informal. Recently, the scholarship on accountability has started to distinguish between formal and informal accountability mechanisms, each of which can be vertical, horizontal or diagonal. For instance, accountability relationships can take place in a parliamentary arena where formal and informal accountability behaviour of political actors is increasingly coming to light and often analysed in terms of political clientelism (Lindberg 2009). Thus, any study using the term 'accountability' needs to select a specific meaning or meanings of the term for use in a relevant context. In this study, the first step is to delineate precisely the meaning of accountability as part of the drive for democracy.

\subsection{Accountability in a democracy}

In their recent work, Esaiasson and Narud (2013) conceptualize 'democracy' as a two-way process of interaction between the represented and their representatives. This dualist nature of democracy gives it a Janus-face, both egalitarian (of and by the people) and elitist (for the people). Political scientists usually take an institutionalist, egalitarian view of democracy in an election mode: the key mechanism is voter behaviour and turnout. For a relatively short time, many public issues are simultaneously debated among the represented and the would-be representatives seduce them with complex packages of proposals on holistic (party) platforms.

Olsen (2015), calls for the re-examination of what democratic accountability means and implies in different contexts (particularly in less institutionalized contexts, e.g. in developing countries) and the role of citizens, elected representatives and non-elected officials. Also, he questions the long-standing tradition of looking at accountability from the perspective of whether agents comply with authoritative mandates and the effectiveness of different regimes in terms of monitoring and controlling agents, detecting and preventing noncompliance and achieving public objectives. By contrast, Olsen (2015:2), suggest that scholars should look at who can hold whom to account for what, according to what normative standards and why. This view triggers a thorough understanding of the concept beyond formal contexts as an element of governmentality. 
Figure 2: Conceptualising accountability within a democracy

(Source: inspired by Bovens 2007 and Willems 2010)

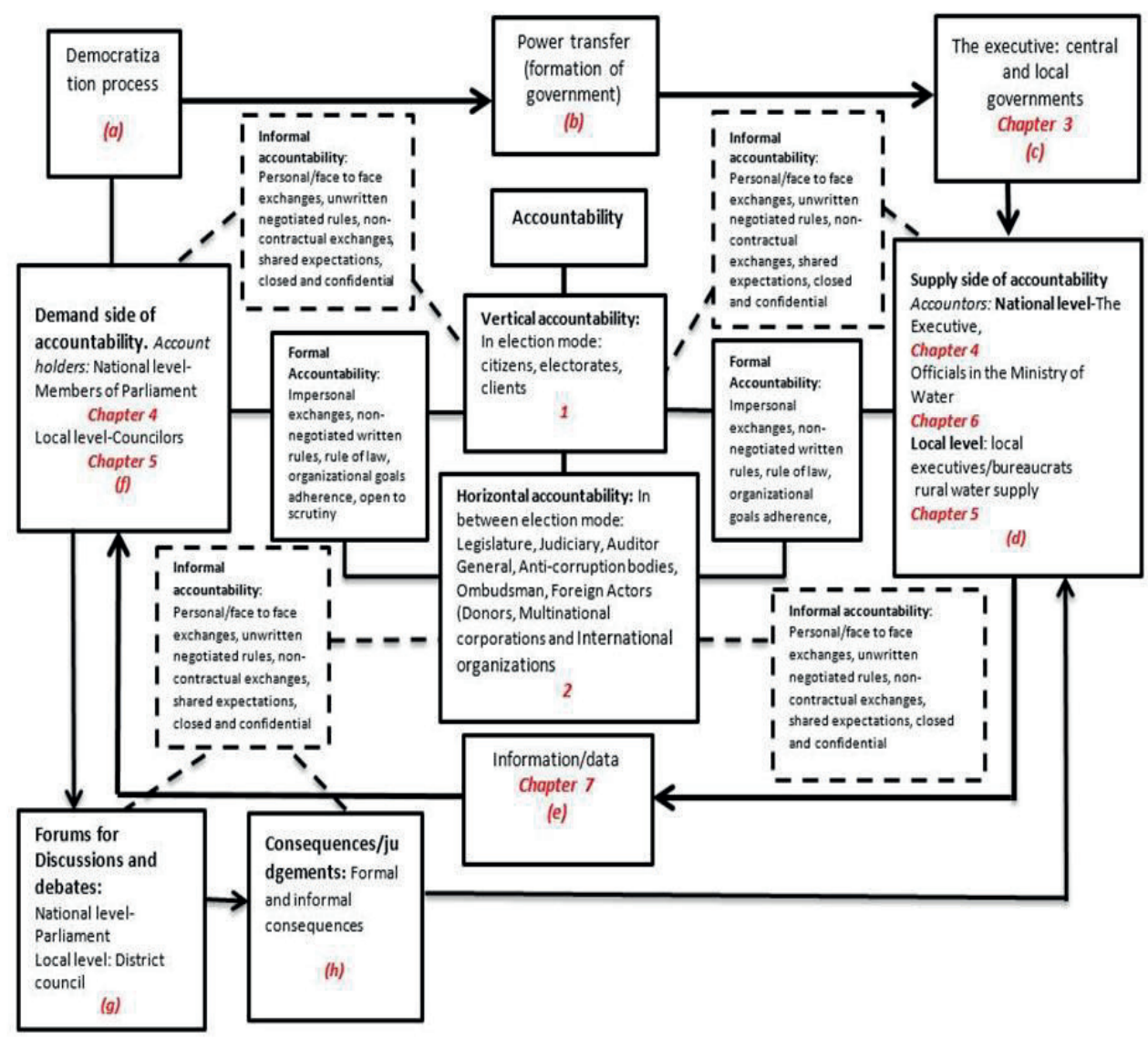

Accountability is usually a product of democratization process (Figure 2). A democratic election is a fundamental principle of power transfer ( $b$ in Figure 4) and formation of democratic governments (c). Through democratic elections, the people or electorate elect their representatives who form a government (c). In contrast to political scientists, many policy scientists and public administration analysts stress this longer period of the inevitably rather elitist between-election mode of democracy.

Once elected, the representatives or selectorate exercise the power delegated to them over the represented or electorate (De Mesquita and Smith, 2012). When a new government is formed elected politicians and appointed officials have the power and authority to translate election manifestos into implementable policy proposals so as to provide services to citizens (c). Assuring the integrity of elections is difficult (Norris et al., 2014) (1), but holding the elected officials accountable in between-election periods is much more difficult (2). In vertical accountability relations, citizens are expected to directly or indirectly and through Civil Society Organisations (CSOs) scrutinize and police the actions of public officials and take appropriate, punitive 
measures, including voting the leaders out of office whenever they fail to perform their duties as they are expected to (1). Public officials (both in the central and local governments) are supposed to provide information to citizens (or citizens' representatives, i.e. Members of Parliament and councillors) regarding their performance (d). Then, citizens/CSOs discuss the information and judge their performance and, in case of bad performance, impose sanctions. However, the P-A perspective in vertical accountability relations is limited by two modes of asymmetrical information distribution, i.e. moral hazards that occur when the action cannot be observed by the principal (citizens/CSOs) and adverse selection which refers to the risk arising from not knowing the habit and character of agents (public officials) (Poth and Selk, 2009).

To remedy such shortcomings, accountability mechanisms in the longer between-election mode is crucial (2). The mechanisms for holding public officials accountable in the longer betweenelection mode include the rule of law, guarded by an independent court system; the rules, habits and resources of responsiveness, a Parliament's answerability to and controllability by the electorate (Hyden, 2010); and the rules, habits and resources from the executive to the parliament and courts of law. For instance, in the parliament, political officials (e.g. ministers) are held accountable during the question-and-answer sessions (2). They are required to provide information regarding the performance of their ministries during parliamentary debates and discussion sessions where Members of Parliament discuss and judge their performance ( $\mathrm{f}$ and $\mathrm{g}$ ). A similar practice manifests itself at the local level where councillors are required to hold to account public officials on a district council platform and impose sanctions (f, $g$ and $h$ ).

As shown in Figure 2 above, accountability presupposes power relations between account holders (the demand side of accountability) and accountors (the supply side of accountability). For purposes of this study, account holders include Members of Parliament at the national level and councillors at the local level (f). Accountors include the executive (ministers, a prime minister, a president) at the national level and executive officers (district executive directors, heads of department) at the local level (d). These actors interact in confined power relations which can be vertical, horizontal, formal and informal when demanding, rendering, assessing, and responding to accounts (Figure 2).

\subsubsection{Vertical and horizontal accountability}

As indicated in Figure 4, accountability in a democracy takes place in a two vertical and horizontal dimensions (Cendon, 2000; Kenny, 2002). In its vertical dimension (1), accountability is a relationship that links citizens (voters) to political leaders through democratic elections both in local and national political settings. This type of accountability corresponds to accountability during election periods where voters hold political leaders to account through universal suffrage after serving for a given, constitutionally agreed term limit (Figure 4-1). It is also a relationship that links them to high positions of the administrative structure, i.e. officials who are appointed and removed by the president within the ranks of the bureaucracy (Cendon, 2000).

In its horizontal dimension (2), accountability is a relationship that links the government with the parliament (Cendon, 2000). It refers to the existence of state agencies that are legally enabled and empowered, and factually willing and able, to take steps that range from routine oversight to criminal sanctions or impeachment in relation to commission or omission by other agents or agencies of the state that may be qualified as unlawful (Cendon, 1999:38, cited in Kenney, 2000:2). Here, three aspects of horizontal accountability may be identified: who exercises horizontal accountability (state agencies); what the exercise of horizontal accountability consists 
of (oversight, sanctions, impeachment); and with respect to what kind of commission or omission can horizontal accountability be exercised (those qualified as unlawful) (Kenney, 2000).

However, parliamentary political systems differ from presidential ones, for in presidential political systems this horizontal relationship of accountability does not have a permanent and direct character (Cendon, 2000). Thus, while in parliamentary systems a parliament participates in the formation of a government and controls its performance in a permanent and direct mannerthrough mechanisms such as questions, interpellations, votes of confidence, motions of censure, parliamentary committees -, in presidential systems a parliament can only approve or reject certain appointments for high political or administrative positions and, only in very exceptional cases, force their resignation through the impeachment procedure (Cendon, 2000:29). Nevertheless, even in parliamentary systems, the Parliament does not act in the same manner as any other mechanism of administrative control (Cendon, 2000). It tends to focus only on specific issues, rather than continuously monitoring all areas of government. Thus, it is more of a deterrent for preventing the malfunctioning of public administration, than a means of correction through accountability mechanisms (ibid). However, parliaments also set up supportive monitoring institutions, like a General Accounting Office, or an Ombudsman- function.

\subsubsection{Formal and informal accountability}

As demonstrated by numerous law and social science scholars (Hyden, 2013; Helmke and Levitsky, 2004; Innerarty, 2013; Kersall; 2008), no rules can exist which exhaustively and unambiguously prescribe their own application. There is always room for interpretation and creativity - and subversion, which means that normally, informal institutions with their own set of informal rules exist alongside formal accountability rules (Helmke and Levitsky, 2004). For Boven (2007), accountability means that not only do the consequences have formal and informal aspects, but that the forum, the information, the debating and the judgment are doubled too.

In Africa the implications for accountability of the informal 'economy of affection' (Hyden, 2013) or 'the politics of the belly' (Bayart, 2009) are particularly relevant, just as are cases in which outright (sometimes state-protected) criminal networks do the 'doubling' (Bayart et al., 1999; Chayes, 2015; De Mesquita and Smith, 2012). As a result this may either positively affect the formal accountability system by accommodating or complementary effects, or undermine it by substituting for it or by making it compete with the formal rule system (Helmke and Levitsky 2004). Accordingly, the myriad of accountability chains that result from the formal and informal accountability relationships are a concatenation of accountability chains (solid boxes and arrows in (Figure 4). The involvement of international donors and inter- or transnational donor organizations in the Tanzanian national accountability chains described e.g. by Tilley (2014) are added to the national relationships and actors identified above.

Thus, this study understands accountability in its formal and informal sense and in the interplay between them. It departs from Bovens (2007) who defines accountability as formalized accountability which is a social relationship between an actor (a minister, a civil servant, etc.) and a forum (e.g. a parliament, a district council), in which the actor is obliged to explain and justify his/her conduct, after which the forum may pose questions and pass judgments. Finally, the actor faces certain consequences of his conduct. This formal accountability is usually elaborated in extensive rule systems. Therefore, judging rule application and rule following in accountability issues, inevitably becomes a complex judgmental game. The study also follows Innerarty' s (2013); Helmke and Levitsky's (2004) observation that informal institutions, with their own set 
of informal rules which consist of 'habitus', 'codes', predispositions or cultural bias, exist alongside formal accountability rules.

The natural perspective of bureaucratic theory puts it well that, 'formal role definitions and written rules may have been developed, but all too frequently they exhibit little or no influence on the behaviour of members' (Gouldner, 1954 cited in Scott, 2003:35). The informal accountability perspective stresses the understanding of the normative structure (what participants are supposed to do) over the behavioural structure i.e. what participants do (Scott, 2003). Thus while the R-MTs in formal accountability are derived from formal bodies of knowledge, belief system as well as state institutions, those in informal accountability emanate from unwritten, non-specified rulesin-use guiding spontaneous interactions and shared expectations of actors (Helmke and Levitsky, 2004; Hyden, 2006).

\subsubsection{Accountability as an element of governmentality}

Under a governmentality approach, 'formal accountability' may be viewed as a particular type of rationality that informs practices in terms of how institutions and actors should be governed in systematic ways so as to regulate and control their behaviour. Here, actors are 'office holders' (as distinct from their personal (power) relations or personalities). It is the formal role expectations as stipulated by rules and decrees, by which they are assigned tasks to perform. In that case, formal accountability pre-supposes pre-defined power relations between two kinds of office holders, namely account holders (Members of Parliament and councillors at the national and local levels) and accountors (executive officials at the national and local levels).

This view is consonant with a rational perspective in the broad sense of bureaucratic theory. This rational perspective views 'rationality' as a series of actions organized in 'such a way as to lead to pre-determined goals with maximum efficiency' (Scott, 2003:33). One of the peculiar features of this type of rationality is 'formalization'. Governance practices are 'formalized to the extent that the rules governing behaviour are precisely and explicitly formulated and to the extent that roles and role expectations are prescribed independently of the personal attributes of individuals occupying positions in the structure' (Scott, 2003:35). The idea is to make behaviour more predictable by standardizing and regulating it (ibid). The World Bank is a prominent example of such a rational organization. In 2004, the organization introduced an innovative element in its rationality, called the 'Accountability Triangle'. This model advocates accountability relations between three important actors in the service delivery chain: the poor, service providers and politicians (Wit and Akinyoade, 2008). However, singling out 'the poor' from among 'the citizens' as special account holders may appear to be an 'innovation' in general P-A accountability theory. It logically implies that any 'target group' of a specific policy might be selected as account holders. But this runs counter to general democratic theory and practice, which gives a right to any adult citizen of a country to hold office holders to account.

Viewing formal accountability from the point of view of mentalities means understanding it as a regime of practices 'embodying certain forms of knowledge and beliefs'. The knowledge in question is usually uncodified or tacit 'stocks of knowledge'. For example mentalities of being a dependent partner without questioning one's position. the need to give aid in the form of 'projects' that buy into the mentality of account giving of the electorate in donor countries (Rottenberg, 2002); versus aid in the form of budget support for national/local governments which buys into the mentality of 'politics of the belly' and extraversion of local elites. 
Equally, formal accountability can also be understood from the 'technologies' concept of governmentality. The focus here is on the material and organizational sense of 'designs for accountability' is significant in this this context. For instance, budgetary accountability, efficiency approaches in government and the organization of particular data sets for accountability relationships, e.g. the "Water Point Mapping (WPM) system" and the "Big Results Now (BRN)" initiative in the water sector in Tanzania, constitute the organizational sense of designs for accountability. Returning to the example of WB's accountability triangle' the key question from the 'technology' element of governmentality would be: what 'technology innovation' it brought except maybe more stakeholder participation in certain projects.

Technologies also involve practices, processes, conditions and mechanisms and interrelationships between them (ibid.). For instance, New Public Management Reforms (NPM) draw on different technologies and practices to inform public sector accountability reforms based on Weberian rationality. Viewing NPM accountability-driven reforms through a governmentality lens means paying attention to the technologies behind such reforms with which they are justified within a complex network of accountability relationships.

\subsection{Conclusion}

Formal and informal accountability may be understood as an element of governmentality in which formal and informal institutions are in constant interactions in a socially embedded practice interwoven with the fabric of society-government relations and blended together to produce a regime of practices that binds together the actors, thus becoming a way of life. The result is a 'dual' institutional governance and accountability system. In this context, therefore, formal and informal accountability mechanisms are founded on various governmentalities that structure the behaviour of its members in a manner that is seemingly acceptable to all members and not susceptible to questioning by those who are part to it.

The empirical chapters five, six seven and eight present the findings on how public officials at the national, transnational and local government levels are held to account in a context of governmentality. But I will present the historical context first. 


\section{Accountability in historical context}

As highlighted in the introduction, in order to understand accountability and water service delivery issues, they need to be located in a broader context of historical governmentality in different historical periods. This makes it possible to understand the context in which the current accountability practices in the water sector came into existence. Therefore, this chapter examines accountability practices from the pre-colonial through the colonial to the post- independence period. The objective is to understand how past accountability practices have influenced and continue to influence the current ones and the challenges they pose to effective delivery of water services. First, however, I will present some general information about Tanzania

\subsection{Back ground information}

The United Republic of Tanzania (URT) came into existence in 1964 after the union of two independent countries, namely Tanganyika and Zanzibar ${ }^{6}$. All state authority in the United Republic is exercised and controlled by the Government of the United Republic of Tanzania and the Revolutionary Government of Zanzibar. Each central government has three organs: the executive, the judiciary and the legislature; these have powers over public affairs (URT, 2004:5). Since the end of its first post-independence government in the1980s, mainland Tanzania has held five presidential and legislative elections.

The 2012 population and housing census shows that Tanzania has a population of 44,928,923; $43,625,354$ people live in mainland Tanzania and 1,303,569 people in Zanzibar ${ }^{7}$. Tanzania is regarded as one of the most diverse countries in Africa with more than 120 ethnic community languages. Kiswahili is the national language that is widely spoken in the country, while English is the official language of education, administration and business. Ninety-nine percent of the local people are native Africans (95\% of these speak Bantu languages); Asians, Europeans and Arabs make up the remaining one per cent. Most of the people are Christian and Muslim and a few people are Hindu and atheistic ${ }^{8}$. A pew 2010 pew forum survey estimated that approximately 60 percent of the population is Christian, 36 percent Muslim, and 4 percent members of other religious groups ${ }^{9}$.

The Tanzanian culture is a product of African, Arab, European and Indian influences ${ }^{10}$. Despite this ethnic diversity and a population potential for robust economic growth, approximately $28.2 \%$ of the population lived below the poverty line in $2012^{11}$. Inequality between the urban and rural population has increased and approximately 12 million Tanzanians are living in poverty ${ }^{12}$. This is a cause for concern, particularly with regard to the provision of social services, including water.

\footnotetext{
${ }^{6}$ The research in this study was focused on Tanzania mainland. However the Parliament of the United Republic of Tanzania also includes members of parliament who come from Zanzibar. Thus accountability discourses of Tanzania MPs presented in chapter four also include those representing constituencies in Zanzibar.

${ }^{7}$ http://www.foreign.go.tz/en/tanzania

8 ibid

${ }^{9}$ www.state.gov/documents/organization/208416.pdf

10 ibid

${ }^{11} \mathrm{http}: / /$ www.worldbank.org/en/country/tanzania/overview

$12 \mathrm{ibid}$
} 
Figure 3: Map of Tanzania

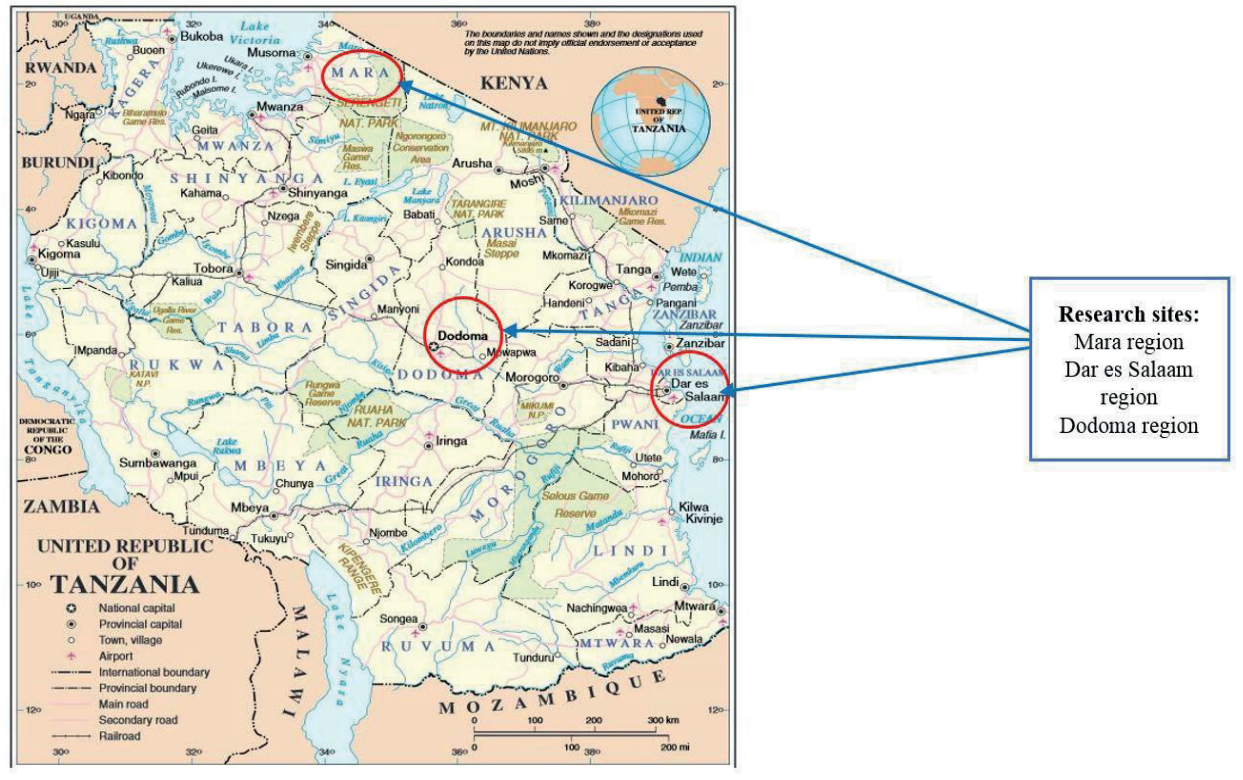

As seen in Figure 3, the country has a large number of water sources, including lakes, rivers and the Indian Ocean. Given the abundance of the sources of water in the country, one may assume that the country does not have problems of water, with regard to access. This assumption is totally wrong. The recent report on "Progress and Sanitation on Drinking Water", released by UNICEF and WHO in 2015, shows that Tanzania has not made enough progress, with regard to achieving the Millennium Development Goal of improving access to clean and safe water (UNICEF and WHO, 2015:4). The country is among the countries located in sub- Saharan Africa and Oceania in which less than $50 \%$ of the population has access to improved drinking water sources (ibid.). These statistics come at a time when there is an increase in donor support in the water sector in Tanzania through multilateral and bilateral financial and technical aid.

Administratively, the URT is composed of 36 regions, 29 regions on the mainland and 5 in Zanzibar. The official capital of Tanzania is Dodoma. Despite this, Dar es Salaam, which is the country's commercial city, is the main administrative hub, headquartering most government institutions, including ministries, agencies and other administrative institutions. The data for this study were gathered from three regions (circled in figure 3), notably Dar es Salaam, Mara and Dodoma.

Tanzania is a hybrid nature of the semi-presidential and semi-parliamentary form of executive adopted in 1962. This hybrid is exacerbated by the single party rule of 1965-1992, and has nominally succeeded in formally balancing power by institutional and rule changes, but continue to struggle with its legacy (Mukangara, 2005:184). At the apex is the President who is assisted by a vice-president and a prime minister and a cabinet (ibid). The ministers are political appointees of the President, but are directly accountable to the legislature. Politically, Tanzania has been a one-party state since attaining independence in 1961 until de jure 1992 and de facto subsequently (Hoffman, 2006). In the last two decades, the political landscape of Tanzania has changed from a 
constitutionally entrenched single-party system to an openly competitive multiparty system (Lofchie, 2014). This transformation was a response to the political liberalization reforms engineered by the WB and IMF, carried out under the good governance mantra. The reforms were imposed on the country as a conditionality for it to obtain foreign aid. The transformation opened a democratic space for competitive multiparty politics in 1992.

Although Tanzania became an official multiparty democracy in 1992, Chama Cha Mapinduzi (CCM) is by far the dominant political organization (Hoffman, 2006). The current ruling party, CCM, is a union of the Tanganyika African National Union (TANU) from the Mainland and the Zanzibar-based Afro-Shirazi Party (ASP). CCM was formed in 1977 (Morck, 2005, cited in Hoffman, 2006:16).

Civil Society Organizations (CSOs), including Non-Governmental Organizations (NGOs), Community-Based Organizations (CBOs) and Faith-Based Organizations (FBOs), are important non-state actors in Tanzania. The proliferation of CSOs in the country was a direct consequence of the Structural Adjustment Programmes (SAPs) implemented in the 1980s by the WB and IMF for the purpose of revitalizing the ailing economy. In order to contain the cost of running the bloated bureaucracy, the SAPs focused on the rapid privatization and downsizing of the public sectors. This led to increased funding for CSOs provided by donors. Foreign donor funding strategies emphasized the strengthening of CSOs, instead of state institutions which were regarded as inefficient and corrupt (Haapanen, 2007). The political liberalization reforms of 1992 strengthened the position of CSOs and created a space for them to participate in development undertakings in collaboration with the state. With the increasing number of CSOs the question, is whether they have the capacity to carry out oversight activities in relation to the state and whether the state listens to them. Apparently there is competition as donor funding is shrinking, particularly funding for local CSOs compared to funding for international CSOs. Thus, it is vitally important to show the impact of their work in order to obtain sustained funding (Haapanen, 2007).

Economically, Tanzania has progressively moved from a centrally planned economy regulated by the state to a free market economy driven by capitalist principles. The move began after the economic liberalization reforms pursued alongside political liberation reforms under the influence of international donors, notably the WB and IMF. Statistics on economic growth suggest that macroeconomic performance is overall strong. Real gross domestic product (GDP) grew by $7.3 \%$ in 2013 and $7.0 \%$ in 2014 (World Bank, 2015). The main sources of this macroeconomic performance are the agriculture sector, trade, the transport sector and the construction sector. For instance, agriculture accounts for more than $40 \%$ of the GDP and provides $85 \%$ of the country's exports and employs $80 \%$ of the total workforce (URT, 2014). The role of Information Communication Technologies (ICTs), particularly mobile phones, in economic growth has also been critical. Tourism, mining and small-scale industries are increasingly contributing to national economic growth as well. However, the welfare of the general population does not match the positive macroeconomic performance. The provision of social services, including water has registered little progress, despite huge donor and government investment.

The future economic development of Tanzania depends on how the country harnesses and utilizes its recently discovered oil and gas resources in the southern regions of Mtwara and Ruvuma. The discovery of oil and gas has enabled the country to open another chapter of development cooperation between international investors from the west and the south (particularly China) and national government officials. Resources generated from these natural resources are expected to 
play a key role in funding development endeavours, including the delivery of socials services such as water. The question on many people's lips is whether Tanzania will become 'a resource curse country' as the West African countries like Nigeria have become. Therefore the issue of accountability is critical.

\subsection{Accountability in historical governmentality}

The current accountability practices in Tanzania did not emerge from scratch. They are a product of governmentalities that have influenced and shaped the country across different historical periods. Understanding this history will help us grasp the governmentalities that drive current accountability practices in Tanzania.

\subsubsection{Pre-colonial Tanzania}

To a great extent pre-colonial Tanzania, was largely patrilineal and very hierarchical. In this regard, the people surrendered all power to a 'chief' or 'big man' from the mentality of being one family. However, there were diversity of political formations which suggested different ideas of society's culture, traditions, customs, trade, military conquest and slave trade (Kersall, 2008:2). For instance, the political organisation among the Massai in northern Tanzania, was based on age, gender and seniority. The youth, known as Morans, protected the community as a rite of passage to senior political leadership. After succeeding in this initiation process, they became junior leaders. Ultimately, with time and on the basis of age, they became senior leaders of the community. Women were responsible for bearing children and carrying out household activities. Thus, accountability relations in the Maasai community were based on the principle of seniority i.e. junior political leaders where directly accountable to the senior political leadership.

Before the arrival of Arabs in the 13th century and Europeans in the 16th century, the territory currently known as Tanzania was home to a rich diversity of political formations. 'The trend was from small bands of hunter-gatherers, to village based agriculturalists, to more or less militarized chiefdoms and kingdoms, to empires based on production, slave-raiding, and trade' (Kersall, 2008:3). According to Oliver, and Atmore (1967:80), the incursions of the Ngoni from the south, formed bands of warriors who had broken from Shaka Zulu kingdom (in the now South Africa) defeating bands they encountered on their long northward trek ${ }^{13}$. In the late 1830s, the Ngoni spread across much of western and southern Tanzania to the east and west of Lake Malawi, where they finally settled as ruling aristocracies (ibid). The Ngoni people's military tactics were adopted by the new groupings of ethnic communities which were engaged in military conquests in Tanzania and were used for territorial expansion and for amassing wealth during the fights.

\footnotetext{
13 "The first Ngoni warriors invaded southern Tanzania in the late 1830s, setting the stage for an extremely violent nineteenth century. The Ngoni are typically described as having an origin in southern Africa. Using infantry techniques developed by Zulu warriors, they made their way into what is now Tanzania in the 1830s from bases in Malawi" (Waters, 2009:64)
} 
Figure 4: Ethnic groups in Tanzania

(Source: Lindemann and Putzel, unpublished paper)

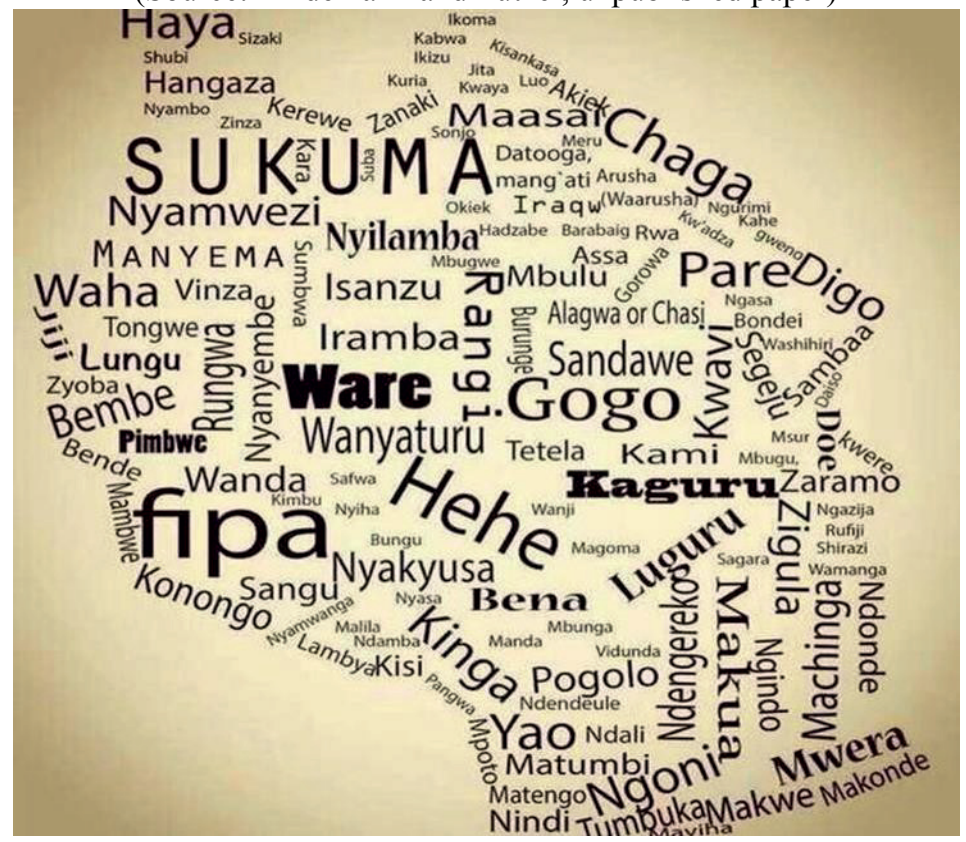

Equally, warrior bands, called ruga ruga in Nyamwezi country present day Tabora, in the west of Tanzania roamed the country side, plundering wealth (Oliver, and Atmore 1967:80) ${ }^{14}$. A young Nyamwezi chief, Mirambo appropriated groups of the Ngoni ruga-ruga and used them to build and extend his chiefdom in the western part of Unyamwezi (Oliver, and Atmore 1967:80) ${ }^{15}$

\footnotetext{
${ }^{14}$ According to Tony Waters, ' $t$ the term 'Nyamwezi' applies to a variety of status groups which are found in Tanzania today, and in the past. Today, the term refers to speakers of a language living in the Tabora area. In the nineteenth century, the term was also applied to low status occupational status group, including the porters who carried goods from the interior to Bagamoyo on the Indian Ocean coast on behalf of Arab traders. Also, nineteenth century explorer accounts of Rukwa describe these chiefs of the Pimbwe, Kimbu, and Konongo as being Nyamwezi. Well-known chiefs in Rukwa identified as Nyamwezi included Mirambo of the Nyamwezi, Simba of the Konongo, Nyungu ya Mawe of the Kimbu, and Kasogera of the Pimbwe" (Waters, 2009:62).

15 The term Rugaruga meant "boys who were separated from their families at a young age, and raised to be the personal retainers/soldiers for a chief. They were raised in chiefly courts to be loyal to their commander. The status was acquired as a result of initiation rituals, not birth" (Ibid, 61). They were also described as "wild young men, a heterogeneous collection of war captives, deserters from caravans, runaway slaves, and others without roots or family ties, and they owed no allegiance other than to their chief or leader...standing armies of young, unmarried professional soldiers, especially trained to fight and terrorize their enemies, often wore mutilated parts of the bodies of their enemies as ornaments, and their name is said to derive from this fact" (Shorter, 1972 cited in Waters, 2009:62)
} 
These political developments, including, the Ngoni incursions into Tanzania and the rugaruga warrior bands which swept many political formations in pre-colonial Tanzania contributed to the gradual emergence of ethnic identity (Kersall, 2008). These developments were at the heart of social and economic transformations, including more centralized political formations (Kersall, 2008; Oliver and Atmore, 1967). For instance, the centralized state of the Hehe in central and southern Tanzania was formed in this way (Oliver and Atmore, 1967). However, [b]ands, chiefdoms, kingdoms, empires, rose and fell depending on their success in securing subsistence, wealth, and security for their members through hunting, production, warfare and trade (Lonsdale, 1981:172; Vansina, 1990, cited in Kersall, 2008:3). Thus, the pattern of political evolution was not consistent or linear across Africa, and Tanzania in particular (ibid). External forces such as the Ngoni incursions and internal conditions played an important role in such political formations.

One pertinent question regarding the pre-colonial accountability practices in Tanzania is the question of political power. Where did the pre-colonial leaders derive their power and authority from? As noted in chapter two, accountability relationships presuppose power relations between different actors in a political system. These power relations may be horizontal, vertical, formal or informal. Therefore, understating the source of power of that period is very important. Tim Kersall and many other anthropological scholars in Tanzania such as Steven Feierman, Roland Oliver, Anthony Atmore and Tony Waters have provided answers to this question. According to Kersall (2008), the pre-colonial leaders (chiefs) derived their power and authority from economic and social spheres. In this regard, Kersall notes:

"Economically, big-men tended to control access to land and reproductive power: these were the main coordinates of what has come to be called a lineage mode of production, the different variants and remains of which can be found all over Africa today...Another source of big men's authority was their organisation of what we might call public goods. For example elders might coordinate collective action for bush clearing (both for farming and to push back tsetse fly), harvesting during peak agricultural periods, terracing, and maintenance of irrigation furrows where these were used. In larger scale societies, some of these functions would be under the overall authority of the chief” Kersall, 2008:4).

At the centre of these production relations based on land as a source of power were chiefs and kings. For instance, land was a common source of social and economic power in the Shambaa Kingdom in the north-eastern part of Tanzania. Thus, controlling access to land was very significant to the king's power. The king, in this kingdom, had the title of Ng'wenye shi, 'owner of the land' (Feierman, 1990:68). Ownership meant control over the land in its political sense in the same way the owner of a village (referred to as $\mathrm{Ng}^{\prime}$ wenye mzi) owned the village. Thus, to be a land owner implied having the right to collect tribute from one's subjects (Feierman, 1990:68). Describing this practice, Feierman writes:

"In times of hierarchy, the entire land was governed by the king, was divided into units, each of which was called 'a land in turn' and governed by a subordinate chief. The typical chiefdom, the land of one chief had boundaries which ran up and down the escarpment as well as the unoccupied "nyika" below them ${ }^{16}$. The boundaries were careful remembered... Chief's residence was built at the top of a hill, with banana groves descending from the edge of the habitations. Chiefs maintained banana groves to attract

16 "Nyika" is a Swahili word meaning unoccupied track of land 
followers to their own. A new arrival would be given a bit of the Royal banana grove. The Chief wanted the land to be filled with people. Chiefs awarded banana groves to their most important officials but then required that the groves be well maintained. Officials paid fines if the groves suffered neglect" (Feierman, 1990: 68).

The payments of fines by important officials working for the chief is an example of an accountability relationship between the chief and these officials, that is, the chief had powers to sanction the behaviour of his workers by punishing them for bad performance.

Meanwhile, the gender politics were exploited by chiefs as another source of political power. In this regard, women were considered essential to the production and reproduction of the political community (Kersall, 2008:5). The sources of power were twofold: on the one hand, chiefs married as many wives as they could; the wives were used to attract young men to the household as consorts (Vansina, 1990, cited in Kersall, 2008:4). Thus, having many consorts meant having potential labour force to work on the land as well as having future political leaders within the chief's circle. On the other hand, the chief's powers then extended to young people's marriages, over which he presided.

Thus, if a young man wanted to marry, to acquire land or to start a family, he sought the consent of the chief (Kersall, 2008). Likewise, in patrilineal societies generally, a man obtained land from his father, but he had to give wealth in the form of labour and livestock to his wife's father (ibid.). Another source of power for the chief was the exploitation of refugees' desperate situations in times of war. For instance, 'in the Shambaa kingdom of north-eastern Tanzania, the chief provided the ultimate refuge for families pushed to the margins of survival' (Feierman, 1990:53, cited in Kersall, 2008:4). In addition, where chiefs acquired a large number of livestock, the animals were given to clients who, in turn, had to be loyal to the chief (Kersall, 2008:4). In that case, the economic sources of power rested on the material and physical protection of the family.

The politics of descent was yet another source of political power derived from the personal/family relationships between the King and the chiefs. For instance, village communities were thought of as a single family whose father was the village headman, and the big men of each house were his brothers (Vansina, 1990: 81 cited in Kersall, 2008:5). Thus, smaller houses (which can be interpreted as technology indicating a mentality) in a village could be perceived as descendants from younger brothers (ibid). The Shambaa kingdom in the north- eastern part of Tanzania practiced politics of descent which fell into two alternating configurations: one in which the king placed his children as chiefs in all the chiefdom and therefore expected obedience from them; the other in which he failed to do this and struggled with half-brothers or fathers' brothers who refused to subordinate themselves (Feierman, 1990:86). Explaining this practice further Fierman writes:

"...When the a new king came to power his ability to dominate the Chiefs depended on whether they were his brothers and therefore his competitors, unlikely to subordinate themselves without a struggle; or non-royals who could be pushed aside; or (best of all) junior relatives. Each king tried in the course of his reign to replace brothers with sons who would obey commands from the royal capital. A king who succeeded in doing this 
made the entire kingdom into a single 'Nguvu' ${ }^{17}$ : A territory with a single locus of sovereign power...” (Feierman, 1990:86)

From the above quote we see that the politics of descent shows practices of governmentalities in which the notion of accountability relationship between the king and the chiefs is based on a personal/family values and traditions. The personal and family values and traditions, determined to a great extent which actions the king should be held to account for and in response, which actions the chiefs should base their claims on in demanding accountability from the King.

A rather interesting account of chief's power concerns the politics associated with governmentalities in the Shambaa Kingdom. In this context, Steven Feierman remarks:

"...The death of a king remained secret until a new king had been installed in the night. At dawn the war drum sounded to announce the death of a king and the accession of a king. The people streamed out to the council clearing to find their new ruler seated, wearing the ostrich-feather head dress. This was the only time the king's subjects were permitted to state openly their conditions for the social contract with their ruler. They greeted him with the royal title 'Simba Mwene' and then shouted...Give us rain. Give us banana. Give us sugar cane. Give us plantains. Give us meat. Give us food. You are our king, but if you do not feed us properly we will get rid of you. The country is yours; the people must have their stomach filled. Give us rain. Give us food. Once the people accepted the ruler as Simba Mwene, 'the lion', they knew that he would be free to take all the wealth of the land..." (Feierman, 1990:46).

The practice of people surrendering to and depending entirely on everything from the chief, who had massive powers, including rain making, made the chiefdom the most powerful institution $^{18}$. It can be concluded that in pre-colonial times the power of chiefs derived from the people's belief in their magic (of rain-making), and in their control over procreational fertility (access to women for all other men) and agricultural fertility (access to land and cattle). This situation could well have developed into what Foucault calls 'biopower' and 'biopolitics', i.e. a governmentality which extends political control and power over all major processes of life of the community itself through 'technologies' that govern human social and biological processes. Of course, the chiefs kept to older power to take life or let live; but these were the first signs of their power as to 'make' life and 'let' die ${ }^{19}$. But this seminal beginning was interrupted and diverted by the critical juncture of the advent of colonialism. It gave chiefs and 'big men' an opportunity to acquire a far more secure and easy source of power: strategies of extraversion.

\footnotetext{
${ }^{17} \mathrm{Nguvu}$ is a Swahili word for power

18 "The chief had powerful medicines for making rain. People invariably argued that centralization of power led to good rains and plentiful crops. Nguvu is the word for power and people debated about whether there was competition, known as Nguvu kwa Nguvu, power against power. If the latter was the case, it meant that one rain maker or the other was holding back the rain, either to erode his competitor support or because he felt that the local peasants were not adequately loyal to him" (Feierman, 1990: 6)

19 The Anthropology of bio politics, anthrobiopolitics.wordpress.com
} 
In general, pre-colonial societies in Tanzania largely reflected local socio-economic and political conditions of chiefdoms of the time. The situation changed when societies started engaging in trading activities with people from outside Africa, particularly Arabs (Oliver and Atmore, 1967). Before the 16th century, there had been a few Europeans and Americans who attempted to carry out trade activities in the interior of Tanzania, especially in the southwestern part of the country. Their activities were limited to the supply of manufactured goods, especially cloth and fire arms, to Arab and Egyptian merchants in exchange for ivory, animal skins, beeswax and Arabic gum (Oliver and Atmore, 1967).

However, it was during the early nineteenth century that Tanzania's (then Tanganyika's) inland people came into in contact with the outside world through a long-distance trade system based in Zanzibar (Iliff, 1969, cited in Waters, 2009:58). This marked the new beginning of African chiefs to be at the forefront not only in trading with outsiders but also in controlling important trade routes. Access to and control over major trade routes was a new source of political power and authority among African chiefs. They seized the trading opportunity in the newly established world markets of ivory and slaves (Kersall, 2008; Waters, 2009). Documenting this phenomenon, Oliver and Atmore say:

"In western part of Unyamwezi chief Mirambo became powerful enough in the 1870's to rival the Arab merchant princes. By 1880 he had gained control of the Ujiji trade route to Lake Tanganyika and was able to threaten even the route leading northwards to Buganda. It was with Mirambo and not with his fellow Arabs that Tippu Tip allied himself in his commercial exploitation of Eastern Zaire'. In the chiefly castes of Rukwa-both the Nyamwezi and Tutsi — controlled routes passing through their territories in order to obtain wealth. The trade routes became more lucrative as the Arab-generated trade in ivory, guns, and cloth increased" (Oliver and Atmore, 1967:42-81).

Control meant that chiefs and their ruga-ruga monopolized trading rights and demanded payments from the caravans in the form of guns, goods and other supplies with which they could strengthen their own military position (Oliver and Atmore, 1967:42). In a similar vein, explaining the trade caravans of the 19th in Rukwa, Tanzania, Tony Waters observes:

“...trading caravans in nineteenth century were difficult and expensive to organize, because few areas were secure from raids by locals. Travel was by caravan which carried not only trade goods, but the arms and provisions needed to feed the porters, protect ivory, and prevent slaves from escaping. Explorer's paid tributary passage fees to chiefs who controlled stretches of the road. Two safe spots for the caravans were the fortified cities at Tabora/Kazeh, and Ujiji, which soon became notorious as slave depots during the midnineteenth century. Oral and written accounts indicate that by the $1850 \mathrm{~s}$, the chiefs of southern Rukwa, occasionally purchased slaves, traded foodstuffs to caravans, and most importantly, traded ivory for guns..." (Waters, 2009:65).

The above quote indicate a switch from the magical, mentality-based on 'bio politics' of fertility, to the more rational-commercial 'politics of the belly' by means of strategies of extraversion. Thus, Chiefs and big men refused to be depending on the goodwill of their own subjects, and wanted to become more independent in their power over their own subjects; but, in fact, traded in dependence on their own folk to gradually increasing dependence on foreign traders, colonial foreign states, and global capitalists. 
At this point, pre-colonial Tanzania was gradually being subjected to colonial domination. However, the chiefs remained very powerful in many of the kingdoms mentioned above. They derived their power from military conquests, control over land, reproduction, ideology and trade activities. These sources of power enabled them to acquire resources to rule their communities. In the case of trade, chiefs played the role of middle men in trade dealings with foreigners. This paved the way for them to play a similar role (but in the administrative positions instead of trade dealings) during the colonial and the post-independence periods. As argued by Bayart (2009), 'African decision makers resorted to playing the role of the intermediaries voluntarily between their societies and foreign traders. They embraced a deliberate recourse to 'strategies of extraversion', a term employed to mean practices to acquire material resources and power by brokering trade deals with foreign partners (Bayart, 2009). The immediate result of this phenomenon was the integration of Africa into the premodern economic systems, making Africa an explicit dependent partner but also redefined African decision makers' relations with the rest of society (Bayart, 2009). This would later define power relation between African states and the society but also more broadly with foreign actors. Below, I describe the colonial period, including its influences on accountability.

\subsubsection{The colonial period: German and British colonial influences}

The colonial domination of Tanganyika, first by Germany (1885-1920) and then by the United Kingdom (1920-1961), was motivated by economic interests following the growing demand for markets for manufactured goods and for raw materials to keep industrial production running in the two countries. The broader context for this motivation was the rapid economic transformations that were taking place in both countries in the name of 'industrial revolution'. The industrial revolution resulted in the accumulation of industrial capital which was re- invested abroad to generate more profits, hence Marx's prediction that capitalism would be turned into imperialism, the highest stage of capitalism. To achieve the economic objective of obtaining markets and raw materials, it was necessary for the European states to acquire colonies through the 1884 Berlin 'scramble and partition of Africa' blueprint and to establish colonial administrations. Citing the views of a German official regarding the economic reasons for having colonies in East Africa, John Iliff says: "We have not gone to East Africa to found plantations for 3-400 people, but to make a vast country bloom, to find raw materials and create markets for German trade and German industry" (Iliff, 1969:91). This confirms the economic logic of colonization. In order to achieve their economic goals, the two colonial masters used different styles and strategies of administration. The Germans used direct rule, whereas the British used indirect rule. Next, I describe each of these kinds of colonial rule, including its subsequent system of administration, and its influence on the current accountability practices.

\subsubsection{German colonial rule: $\mathbf{1 8 8 5}-1990$}

Germany's early acquisition of Tanganyika was facilitated by agents working for the German East Africa Company. One notable personality was Carl Peters, a trader, explorer and colonial agent who worked for the German East African Company. His mission included, among others, signing treaties with local chiefs, paving the way for the eventual colonization of Tanganyika. In late 1884, he managed to sign treaties with chiefs in Sadani (Iliffe, 1969:11). This was backed by the metropolitan government in Germany. According to Iliffe (1969:11), the Germany East Africa Company was theoretically responsible for the administration of Tanganyika from 1885 
to 1890 . The interests of the company were mostly focused on the coast of Tanganyika. The company attempted to establish a regular administration in 1888 , but later engaged in expeditions inland to sign other treaties (ibid).

Figure 5: Map of Tanganyika as of 1912

(Source: Illife, 1969)

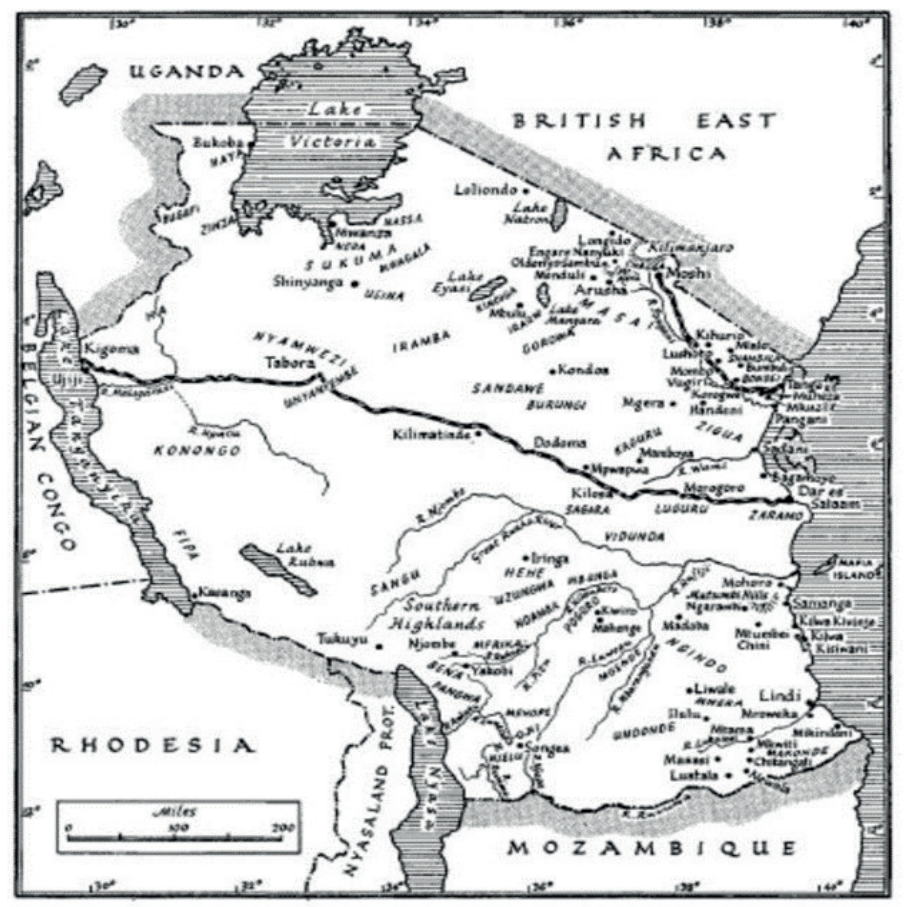

The move to expand the territory inland was met with resistance from the coastal people as they had long established trade caravans and ties with local chiefs through the long distance trade. The resistance stemmed from the fact that the trade between inland and the coastal area was the main source of income to the costal people. Therefore, allowing the Germans passage and access to inland would cause them to lose the profits accruing from the long distance trade. Realizing that colonial domination would be stalled because of the chiefs' economic interests, the Germans deployed an expeditionary force under Hermann von Wissmann. This went hand in hand with the colonialists assuming the administrative responsibilities which previously had been exercised by the German East Africa Company (Illife, 1967:11) ${ }^{20}$.

\footnotetext{
${ }^{20}$ Even when the Germans succeeded in penetrating inland they encountered serious resistance, especially in the southern area of Songea and Iringa. Popular organized resistance efforts included the Maji Maji Rebellion (19051907) and the famous resistance organized by Chief Mkwawa of the Hehe people in Iringa. When news of German invasion reached the Southern Highlands, Mkwawa's rivals hastened to secure this new support. A military expedition sent in 1891 to make terms was seen by Mkwawa as an attack. His forces killed 290 of its members within fifteen minutes. Revenge now became every German officer's ambition. It was achieved when the Hehe capital was taken in 1894. Mkwawa, who escaped, was hunted for four years until he committed suicide to avoid capture (Illife, 1967:17).
} 
To ensure stability of colonial administration inland and to prevent future resistance, the Germans used a 'divide and rule' strategy. Alliances were formed with one chiefdom against its neighbours or support was given to one group within a society against its competitors. The outcome was a number of arrangements between the European invaders and the groups within each region in the colony (Iliffe, 1967:11). The regions organized in this way included: 'the coast, the valley of the River Pangani between the northern coast and Massailand, the complex of chiefdoms to the west of Lake Victoria and its extension southwards among the central core of Sukuma, Nyamwezi, and related peoples, the Southern Highlands, and the fragmented south- eastern section of the colony' (Iliffe, 1969:12). In the northern part, the divide and rule strategy was used much earlier to divide local chiefs in the mountains of Kilimanjaro and Meru (ibid).

The 'divide and rule' strategy worked not only to the advantage of the Germans in terms of reducing resistance for their colonial project, but also to the advantage of local chiefs like Marrealle, who aligned himself with the Germans for extraversion reasons, i.e. obtaining economic benefits so as to govern the rest of the Chagga community. 'By 1905 the coast was firmly under German control and formed the base for inland activities. It held seven of the colony's twenty district headquarters, including the capital, Dar es Salaam' (ibid: 12). Equally, in a bid to establish administration in the coast and inland, German officials negotiated with a peace party of Omani aristocrats, who then became agents of a bureaucratic system of government, providing each major coastal town with a liwali (a governor) and the hinterland with subordinate administrators called akidas (Iliffe, 1969:13). Thus, 'the main activity of the German preoccupation during this time was to regularize the position of chiefs in district administration, to expand European settlement in the north, and to extend the participation of the European community in public affairs' (Iliffe, 1969:18).

In terms of administrative set-up, German administration was highly hierarchical and centralized. At the top of the hierarchy were state secretaries who were accountable only to the Chancellor and, through him, to the Kaiser (Iliffe, 1969:32). The state secretary was responsible for the formulation of policy without being under the supervision of the cabinet (ibid.). This practice made the state secretaries formulate very personal policies without the interference of and accountability to their colleagues (ibid.).

The colonial department, and later the colonial office, was also organized hierarchically. In this context, various officials were responsible only for administrative decisions which they personally ratified by signing the appropriate documents' (Iliffe, 1969:32). Likewise, 'in Tanganyika, the governor was supreme, for he had no executive council and was under no obligation to take advice from any official. The central government in Tanganyika was divided into a number of specialist departments, each headed by a Referent. The Chief Secretary ( ('erster Referent') coordinated these departments, but all important decisions, even on local or technical matters, were taken by the governor, whose signature was required for the majority of documents' (Iliffe, 1969:32).

Thus, the colonial administration was a pure bureaucracy, hierarchically organized, avoiding committees and maximizing the responsibility of the individual civil servant (ibid). Tanganyika was divided into 22 administrative districts with considerable power left in the hands of district officers backed up with military force (Lindemann and Putzel, unpublished paper: 3). 'District 
officers were required to report only their most important decisions to Dar es Salaam. In normal circumstances, they acted at their own discretion. The district officer held enormous power and responsibility. Over those legally natives his authority was restricted only by an order defining the punishments which he might impose (Iliffe, 1969:143). Essential tasks included maintaining peace, order, and good government and to carry out the characteristic duties of early colonial rule, that is, to legislate, collect taxes, and build roads (ibid).

To ensure that the districts were administered effectively, the Germans created a colonial order that would severely weaken the traditional political, economic and military structures of Tanzania (Lindemann and Putzel, unpublished: 3). This order also heavily discriminated against Africans in favour of European interests and Asian traders. Africans were made labourers on sisal and coffee plantations in the northern areas. They were paid meagre wages and taxed heavily. If one did not pay tax one was heavily punished. The power of traditional authorities was further weakened by a mixture of semi-indirect and direct rule practices. Under semi- indirect rule, the Germans made use of chiefs but stripped them of most of their traditional powers (Lindemann and Putzel, unpublished: 3).

Direct rule meant "the state maintained and administered a monopoly of law, policy, and administration to the population without intermediaries, through bureaucrats without independent means of coercion" (Weber, 1991, quoted in Naseemullah and Staniland, 2016:14). Thus, direct rule differs from indirect rule on the basis of an individual's relationship with the colonial state: those under direct rule related to the state as citizens, but with no typical German citizen rights, whereas those under indirect rule were subjects and were under hierarchies of local power (Mamdani, 1996, cited in Naseemullah and Staniland, 2016:14). The Germans used direct rule where there were no strong traditional rulers. Initially, the colonial administration simply took over the Sultan of Zanzibar's officials: liwalis in the main towns, the akidas under them and the jumbes responsible for tax collection at the local level. Later on, the Germans replaced the liwalis with German officials and appointed younger African graduates as akidas and jumbes (Lindemann and Putzel, unpublished: 3).

The fact that Germans made use of stronger chiefs in tax collection ("semi-indirect" rule) not only meant a loss of income for the chiefs (who had been receiving tribute before by controlling important trade routes, owning land, employing ideological and military power), but also undermined their standing in their communities (Lindemann and Putzel, :5). As a result, in some instances, the chiefs found new ways of obtaining resources; for example, they took bribes from German traders who were working as recruiting agents and involved themselves in the recruitment of African labourers to work on German sisal and coffee plantations in the north. With regard to this, John Iliffe writes:

“...Chiefs were bribed to supply their less prestigious subjects. The Governor ruled that recruiters might induce chiefs to encourage their people to accept recruitment, so long as the people, and not the chief, were paid. His ordinance of 1909 made an officially attested contract the only legal means of recruitment. This may have prevented the worst abuses, but in default of a central syndicate it made recruiting highly competitive, raising the costs and producing 'the modern slave hunters', the coloured agents employed by European recruiters. There were said to be a thousand of these agents in Tabora district alone in 1913..." (Illife, 1969: 134). 
In general, German rule in Tanganyika contributed to what Kersall (2008), calls the destruction of social fabric that was to become the basic foundation for ideas about morality, political organisation and accountability by weakening the chieftainship which was a solid system of political organisation. Although in some cases, the chieftainship was favoured, the goal was mainly for economic motives. However, German direct rule was undone by the English rapidly, creating fuzzy and confusing situations for the local power-holders. Exactly such transitionary states may have contributed to the up-rooting of traditional African 'mentalities'. Transitions offer opportunities to real and wannabee power holders to bend new situations in their favour by invoking 'tradition' or older habits.

\subsubsection{British colonial rule: 1920-1961}

The British colonial rule in Tanganyika was established after the defeat of the Germans in the first World War of 1914-1918. After the war ended, the League of Nations promulgated the Versailles Peace Treaty in 1919 giving Great Britain a mandate to govern Tanganyika. The mandate to govern Tanganyika was effected by an order in Council known as the Tanganyika Order in Council, 1920, issued on July 22, 1920 (Taylor, 1963). Unlike the Germans, the British used indirect rule in governing Tanganyika. Indirect rule is a form of political control in which agents of the state delegate day-to-day governance to local power-holders or rather intermediaries in areas considered beyond the reach of the state's direct authority (Furnivall, 1956, cited in Naseemullah and Staniland, 2016:14). Intermediaries, in the context of British indirect rule in Tanzania, refer to African chiefs who had traditional or customary authority in their chiefdoms and who enforced political authority on behalf of the British (ibid). However, the indirect rule policy also carried with it an economic logic, that is, accumulation of raw materials and wealth from the colonies to feed the metropolitan industries. It was established during the governorship of Donald Cameron, who came to Tanganyika in 1925. His enthusiastic support for the policy gave it the status of a "cult" in Tanganyika administrative circles. Cameron was convinced of the effectiveness of indirect rule during his time in Northern Nigeria. Describing the central problem of administration in colonies compared to his home country, Great Britain, Cameron said:

"The central problem for administration is finding the means for communicating with primitive and ignorant people; where as in the United Kingdom (UK)...it is... sufficient to administer the law...indirect rule would undertake administration through chiefs whose positions had foundations in the hearts and minds and thoughts of the people but who would never hold sovereign power" (Cameron, 1939:77 cited in Feierman, 1990:135).

In fact, the objective of the indirect rule policy was to make Africans feel as if they were being ruled by their fellow Africans. This strategy would ensure minimal resistance, but also facilitate the securing of British economic interests by allowing the natives to manage their own affairs through their own rulers, to the extent proportionate to their degree of advancement, under the guidance of British staff and subject to the laws and policies of the administration (Lugard, 1922:94). In addition, the strategy would also ensure the protection of the interests of the merchants and British settlers living in Tanganyika (ibid.). However, the chiefs were not to play the role of native princes; instead, they were to serve as subordinate administrators or influential mediators (Illife, 1979:319, cited in Feierman, 1990:135). Thus, the key to the indirect rule policy was the plugging of UK rationality into an African mentality. A practice describe by (Illife, 1979:319) as 'king-worship without royal powers'. This was done through imposing UK institutions of governance to fulfil colonial objectives, centralizing power, establishing an elaborate system of law and order for regulating and 
disciplining conduct of subjects as well as instituting punishments and rewards system to guide and shape the behaviour of subjects towards achieving colonial objectives.

The idea of having a system of governance modelled along western European traditions introduced governmentalities which did not have roots in the social fabric of African society.

In addition to this fact, the Germans had created a power vacuum when they were defeated by the British, creating a confusing situation for the local power-holders. Such state of affairs may have contributed to the up-rooting of traditional African 'mentalities' as transitions offer opportunities to egoistic power holders to bend new situations in their favour.

A related argument is raised by Ranger (1983, cited in Feierman, 1990:135) who argued that the appeal to king-worship was part of a broader process in which the colonial rulers imposed invented European royal traditions on Africans and at the same time invented African royal traditions for their African subjects. However, Ranger argument raises two issues: the first issue is the extent to which Tudor King-worship was different from chief-big men power in earlier pre-colonial times; secondly, the argument assumes that 'king-worship' Tudor style is an accurate description of UK governance system which may not be the case. Despite these issues, I concur with Ranger on the fact that the result of the fusion of two the styles of governance culminated into a mix of western and African governmentalities which became intertwined together in the day-to-day running of the Tanganyika colony. This can be better discerned if we look at the overall system of British colonial administration and how it worked.

The British colonial administration was modelled on the UK Government in England (Lugard, 1922:95). The governance system was largely hierarchical. The governor served as the Crown in the territorial government of Tanganyika and was responsible for peace, order and good governance in the territory. He also had extensive executive, legislative and judicial powers (Taylor, 1963). However, his powers did not allow him to formulate basic policies; he could do that only when permitted by the colonial office.

The councils (at national and local levels) were more or less similar to the UK Cabinet and Parliament (Lugard, 1922: 95). The detailed work of the administration was carried out by staff who were divided into administrative, judicial, and departmental branches (Lugard, 1922: 95). For instance, the administrative branch was concerned with the supervision of the native administration and the general direction of policy including, tax collection (ibid). In this regard, the main duty of the chief under the "Tudor system" described above was to hear cases and to collect taxes (Feierman, 1990:135). The chiefs had councils designated as native authorities, which collected taxes from the territory subjects, forwarded them to the government, and received a rebate of $25-30 \%$ to be used for financing local needs (ibid).

The collection of direct taxes was given primacy for carrying out the colonial government's activities. Failure to pay taxes was a criminal offence punishable by law. The direct involvement of chiefs in tax collection on behalf of the British colonial administration enabled them to serve British interests on the one hand, and acquire resources for ruling their communities on the other. Thus making extraversion possible and actually imposing it on local power-holders. 
The chiefs' local, colonial expenditures were limited to the salaries of the chiefs and their staff and to some social service provision (McCarthy, 1982:18, cited in Feierman, 1990:135). For instance, in the Usambara District Native Treasury estimates for 1936, 12\% of the recurrent expenditure was allocated to drugs, a game trapper, forest guards, agriculture instructors and hide driers (Feierman, 1990:135). The other 88\% went to clerks, chiefs, headmen and their messengers. This budgetary practice laid a foundation of future budget allocations in the postindependence period where recurrent budget for development is less than the budget for paying political and administrative officials.

Despite integrating indigenous political systems, including the chieftainship system, into the British colonial administration through the establishment of a native authority and the British colonial system of administration in general, the integration process faced certain challenges. Describing these challenges, Feierman notes:

"The British colonial period was marked by a central paradox. For instance in some areas chiefs enjoyed a certain degree of autonomy. In shambaa kingdom chiefs derived a certain degree of autonomy from their mastery of rain medicines. The British used chiefs in order to borrow their legitimacy; the British overlords assumed that peasant's respect for the chief's rain, combined with ancient habits of deference, would lead to smooth acceptance of colonial orders. Yet in practice the chiefs with greatest reputation for rain were the most free to resist colonial orders. They knew that they held the loyalty of their subjects, even without colonial support" (Feierman, 1990:122).

The shifting position of the power of chiefs during British colonial rule enabled the chiefs to acquire a strong middle men position to mediate the interests of the colonial ruler and those of their subjects. In the end, this practice enabled them to acquire resources from the colonial rulers through extraversion strategies and legitimacy from the subjects. However, in order to regulate the power of African chiefs derived from traditional power such as rain making, the British trained Africans to learn the traditions of European intellectuals, of Christian teachers or evangelists (Feierman, 1990:122). This marked the beginning of the formal colonial education system which sought to educate the African minds with western values in order to assist the daily running of the colonies. In this case, uneducated chiefs, in Cameron's vision, were needed only for a period. The next generation of chiefs and their councillors were to be both educated and Christian (Feierman, 1990:138). Describing the need for the Tanganyika colony and the people to educated and Christianized, he wrote:

"The future place in the world of the people of Tanganyika depended very largely on their becoming Christianised...education should strengthen the feeling of responsibility to the tribal community... Since contact with civilization - and even education itself - must necessarily... weaken tribal authority and the sanctions of existing beliefs, and in view of all- prevailing belief in the supernatural which affects the whole life of the African, it is essential that what is good in the old beliefs and sanctions should be strengthened and what is defective should be replaced. The greatest importance therefore must be attached to religious teaching and moral instruction. (Cameron, 1939:167, quoted in Feierman, 1990:139)"

The above quote is representative of the imposition of western rationality expressed through Christianity and formal education system to African mentalities i.e. informal/traditional ways 
of worshiping gods, objects, animals and informal education rooted in the social fabric of the society, in order to facilitate achieving colonial interests through smooth governing of the colonies by indoctrinating and educating Africans to help in that process.

On the flip side however, this practice would later on culminate into the creation of new class of national government officials who would become national political leaders using former colonial western rationalities of governance such as concentration and centralisation of power to national government, law and order, court system, as their colonial masters to govern the rest of the community, which largely subscribe to African mentalities of governance i.e. personal rule based on; face to face exchanges; unwritten, traditional rules; shared expectations; strategies of extraversion; and reciprocity obligations. However, by choosing chiefs and literate clerks as the two sets of agents, the British colonial administrators had defined the lines of conflict for the post war period (Feierman, 1990:139). There was competition for political power between the two agents anchored around the idea of strategies of extraversion with each group seeking power to have access to resources from the colonial government. The battle between the chiefs and the functionaries would ultimately be resolved by the victory of educated functionaries over chiefs in the political movement which won national independence (Feierman, 1990:139). However, this would not have possible without the internalization by these functionaries of certain key legitimating 'mentality' - lasting legacy of old layers of beliefs and habits in their collusion with new, modern, western ones.

What is quite clear from the British colonial administration in regard to future accountability practices is that in any event the African agents of British colonial rule brought with them historically conditioned patterns of behaviours, understandings of social reality, and definitions of a good society (Lindemann and Putzel, unpublished paper: 6). The result of this was a vast social reorganization in which Europeans and Africans combined to create a new political order based on mythologized history (ibid). This reorganization would in turn influence future interactions between African leaders and the outside world.

The colonial period was therefore a game changer in the way Tanzanian society was organized and governed. It was a period in which the patterns of thought, organization, politics and accountability, which were widely distributed in space and durable across pre-colonial time, were altered and the colonization process had consequential effects on the social fabric. More particularly, Feierman, (1990) elucidates this point as follows:

"...in both the German and the British colonial periods, the colonial regime choice of African agents would profoundly influence the changing character of African life. The two colonial rulers lacked the knowledge of African society to control day-to-day affairs on a practical basis. They did not understand African culture from within and, and therefore could not reason with local Africans to convince them of the wisdom or even the acceptability of particular policies they administered. They chose African agents who used their own words to support the colonial policies they administered. When the colonial chose a set of agents; they were also choosing a form of African discourse; if they chose chiefs, then their policies would be justified in chiefly language..."(Feierman, 1990:120-121). 
The resulting constellation was the foundation for future morality, power and accountability in Africa and Tanzania in particular. The intermediary role of local chiefs and educated clerks in the colonial administration would later on pave the way for an emergence of indigenous bureaucrats and political leaders who previously had operated within the colonial system to become a new class of post independent leaders. These leaders allowed themselves to engage in strategies of extraversion in a patron-client politics context. The result of this was the emergence of a governmentality that found its way to the independent government.

\subsubsection{The post-independence period: 1961 - onwards}

The post-independence period marked a steep decline of chieftainship and the overall colonial rule through Tanzania. The year just before and after independence marked a formal transition for the national's intellectuals (Feierman, 1990). The transition was organized and executed by nationalists under the leadership of Nyerere through the Tanganyika National Union party (TANU) which secured electoral victory in 1958-59 and in 1960 it was allowed to form a government (ibid). However, chiefs too wanted a share of political power in the new postindependent government. They considered themselves as representatives of the people and therefore disenfranchising them from their political roles they had during the colonial times was met with intense resistance. This situation led to conflicts between chiefs and the newly emerged class of nationalist intellectuals.

On the one hand the claims to representation of chief's were centred on the idea that chiefs had enormous connection with local roots where they drew their political power; national political elites were never able to sink local political roots during colonial and after colonial rule (Feierman, 1990). On the other hand, a new class of nationalist intellectuals including Nyerere's RMTs of governing sought to exclude chiefs in the new independent government. Nyerere was of the view that giving chief's political space in the newly independent government would reinforce colonial modes of governing. For instance, in October 1961 Nyerere described his discomfort at finding the chief in control each time he visited a district headquarters:

"It is always a government affair. I am met by the provincial commissioner and by the district commissioner both of whom are likely to be colonial officers, the very men who TANU fought but a few years ago, I am introduced to them by other government officers who are also usually expatriates. I am then introduced to the chiefs and to the officials of the native authority and again I am meeting men who either opposed TANU or who carefully stayed out of the political struggle. Then chaps off to one side I notice a few chaps in torn green shirts wielding banners but looking somewhat forlorn" (Pratt, 1978:108 cited in Feierman, 1990:224)

The 'chaps off to one side' that Nyerere was alluding to were the TANU activists of the 1950s. There was a clear strategy by the nationalist intellectuals represented by Nyerere to side-line the chiefs in forming the newly independent government on grounds of colonial connections as well as opposition to TANU waged by chiefs during the political struggle. Thus, as noted by Feierman, (1990:224), in public debates on the future of chieftainship, TANU leaders focused on the degree to which chiefs had openly supported or opposed the independence movement. The country's new rulers were doing a kind of ex post public political accounting (ibid). However, what is quite relevant, in the context of this study, is that chiefs saw a clear threat to lose their middle men position that they had enjoyed during colonial rule. This political role that they played enabled them to engage in strategies of extraversion to obtain resources in order to rule their communities. 
Therefore, disenfranchising their political roles in the new independent government meant loosing livelihood for themselves.

The resentment of the chiefs caused them forge alliances with the Governor, Sir Edward Twining and the United Tanganyika Party (UTP). The first alliance sought to seek support from the Governor to argue in favour of chief political interests in the new independent government. This resulted in calling a convention of fifty-seven representative chiefs in May 1957 (Feierman, 1990). In his opening remarks "Twining regretted that the territory had recently been experiencing a new phenomenon of a political party composed mainly of people whose tribal links had been loosened, and who had not got the proper respect for the Native authorities and Chiefs. Most of their ideas came from outside Tanganyika, put into their heads by people who did not have the true interests of the territory at heart" (Feierman, 1990:225). According to Governor the only hope for stability in the new independent government was from the tribal system, which was the very crucial anchor of the life of African people in the territory (ibid).

The second alliance aimed to solicit the help of UTP to create a constitutional role for the chiefs in the Tanganyika of the future. The UTP in collaboration with the chiefs explored the possibility of creating a house of chiefs as the upper chamber of a bicameral legislature (Taylor, 1963:158; Glickman, 1972:135 cited in Feierman, 1990:225). The UTP, which was doing its best to block TANU's path to power, also adopted the idea of bicameral legislature with the upper chamber to include outstanding people of all races (ibid). Thus, the UTP political leaders, while wittingly expecting the chiefs to play a central role in the new Tanganyika, they too had vested political interests in the struggle for power; the alliance/collaboration was arguably a win-win situation (Feierman, 1990).

However, the chiefs' collaboration with the UTP, like their collaboration with Twining, cost them dearly in the years after independence (Taylor, 1963:158; Glickman, 1972:135 cited in Feierman, 1990:225). The new government's desire was to build national institutions and to transcend local loyalties (ibid: 226). Its creed, which was pledged in the TANU's founding document, was to fight tribalism and all its isolationist tendencies amongst Africans and to build up a united nationalism (Glickman 1972:134 cited in Feierman, 1990:226).Thus, chiefs and the UTP were a stumbling block in transforming the creed into reality. Expressing the need to exclude chiefs in the new administration, President Nyerere elucidated in 1960:

"Our aim is to remove all that tribal business to be citizens of a single nation...Local loyalties were capable of feeding resentments over economic inequalities. The missionaries built schools in some part of the country and not others, so that the Haya people, the Chagga, and the Nyakyusa were better educated than people in many other groups. This could lead to ethnic conflicts and religious conflicts. In addition, hereditary chiefship violated the central democratic ideals of the equality of all citizens and their equal opportunity to act autonomously. The democratic central government of Tanganyika would be based on political forms new to Tanganyika. There is nothing traditional in the central government of Tanganyika today (Nyerere, 1960:44 cited in Feierman, 1990:226).

Thus, the local system of governance based on chieftainship that had existed during colonialism came to a halt and in its place a system of local government modelled along western principles was instituted. This meant that TANU was operating on western democratic rationality and 
technologies, and, at least temporarily, neglecting mentalities. Actually, the TANU leaders were arguing like those enlightened colonialists who wanted to Christianize and (scientifically) educate Tanzanians; and who saw chieftainship as a temporary phenomenon that would fade away with time. The difference is that TANU wanted to speed up this development by force- of-state, whereas the previous enlightened colonialists saw it as a gradual, spontaneous development.

What Nyerere probably did not understand was that local chiefs maintained powerful ties with local people; cutting the ties was not going to be made possible by excluding the chiefs from the new independent government. The bond between the chiefs and the community was not created overnight, it transcends beyond colonial rationalities, including formal sources of power such as laws, policies, institutions, and formal structures of political rule. What Nyerere succeeded was to destroy the name "chief" but the pre-colonial mentalities, including informal power and roles previously played by chiefs found their way in the new independent government. In fact as (Feierman, 1990) pointed:

“...the pre-colonial image of the power holder did not die easily i.e. the image of power was not easily transformed when the power itself changed hands. The new TANU government closed down the public roles of chiefs, narrowing the charmed circle of public participation until it included only the salaried officials. The bureaucracy held very great powers in 1960's and 70's. This state of affairs grew out of colonial situation in which the only Africans with substantial collective influence were chiefs and bureaucrats. The chiefs lost power leaving the bureaucrats in charge..." (Feierman, 1990:232)

Chiefs continued to exist in parallel, having significant power on their subjects. Equally, the core ideas of chieftainship survived in relations to rainmakers and in the imagined picture of the real locus of power (Feierman, 1990:232). This situation paved a way for pre-colonial mentalities to find their way into the new post independent government. However, the successful disenfranchisement of chiefs from the formal political space of the new independent government ushered in new class of nationalist intellectuals whose rationalities and technologies of governance were influenced by those of the colonialists. Elucidating this point, Ralph Ibbott noted:

"Nyerere had worked to avoid Tanzania becoming a society torn by the disparity of class power. But the seeds of class conflicts were sown from the moment the nationalistic movement formed to win state power. What had got the British out was a movement of the entire country with all its sectors and tendencies. Once they left, however, the new elite defended the colonial hierarchy and salary scales they were in the movement to collect. As is usually the case they considered it unjust for them to be denied what the former rulers had, but were oblivious to the injustice they perpetuated against others condemned to work hard to pay for their greed: insensitive to the pain they inflicted on the less powerful, man or beast" (Ibbott, 2014:34).

More specifically, as argued in the quote above: the colonialists left in place the 'technology' of a bureaucratic apparatus, pay-scales and all. All fitting the western democracy and bureaucracy rationality underlying modern politics. The quote also indicates colonial governmentality that the new class of national government officials embraced in the daily governance practices. In the years ahead, the newly independent government adopted a series of reform measures which sought to restructure the administrative machinery along western Weberian bureaucratic ideals and also 
revamp the economy. Coupled with these measures, the government centralized power along party lines for administrative efficiency, including improving the economic situation of the country. The objective was to arrest three 'enemies' of development as they were framed then, namely: poverty, ignorance and diseases. Another area of reform was to militarise the bureaucracy, by recruiting military officials in the civil service with the objective of maintaining law and order. However, given the centralization of political power to central government and the party, development projects often failed due to the limited participation opportunities afforded to the actual beneficiaries (UNDP and URT, 2015).

This situation plunged the country into economic crisis which offered a window of opportunity for foreign actors to intervene. This scenario therefore was the beginning of the renewal of localforeign actors relationships established in both pre-colonial and colonial times. The difference with previous encounters was that during this time the relationships became structured and institutionalised in the framework of western rationalities and technologies based on economic and political liberalization reforms in the context of good governance mantra. Notably, this would become the main organizing principle for the relations between local elites and foreign actors in the years ahead. Thus, the period from 1986 to 2000's and currently is usually labelled as 'economic restructuring and political liberalization' period (UNDP and URT, 2015).

During the 'economic restructuring and political liberalization' period, the WB and the IMF intervened to rescue the economy by pressurizing the government to implement Structural Adjustment Programmes (SAP's) in 1986. SAP's was a technology of economic intervention designated to improve the ailing Tanzanian economy after a decade of protracted economic decline caused by plummeted oil prices in the 1980's, Tanzania's involvement in the war with Uganda in 1978-79, and internal economic policy failures (Agrawal, et al., 1993:1). However, despite, the introduction of SAPs, public service delivery plummeted and corruption increased in the public sector among public officials struggling to complement meagre incomes (Njunwa, 2007).

From the 2000s onwards, the country formulated and implemented a series of poverty reduction measures aligning them with Vision 2025 which aspires that by 2025 Tanzania should become a middle-income country (UNDP and URT, 2015). Specific reforms in the social, political and economic sectors were later on implemented as well. Equally, the water sector reforms in Tanzania have been implemented in this context. However, despite interventions by donors and local elites in terms of increased budgets, policies, and various development strategies little progress is registered in the water sector. It is in this context that I investigate accountability practices in the water sector. But before moving on, I summarize the governmentalities in the pre-colonial, colonial and post-independence periods. 
Table 5: A summary of R-M-Ts during pre-colonial, colonial and post-colonial periods

\begin{tabular}{|c|c|c|c|c|}
\hline \multirow{2}{*}{ 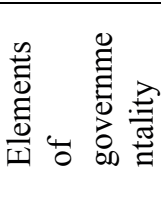 } & \multirow[t]{2}{*}{ Pre-colonial } & \multicolumn{2}{|l|}{ Colonial } & \multirow{2}{*}{$\begin{array}{l}\text { Post-colonial } \\
\text { National and local } \\
\text { government officials and the } \\
\text { society at large }\end{array}$} \\
\hline & & Germany & Great Britain & \\
\hline $\mathrm{R}$ & $\begin{array}{l}\text { The thinking } \\
\text { about } \\
\text { governance } \\
\text { (e.g. power, } \\
\text { morality and } \\
\text { accountabilit } \\
\text { y) is rooted } \\
\text { in the bio- } \\
\text { politics of } \\
\text { agricultural } \\
\text { and } \\
\text { procreationa } \\
1 \text { fertility }\end{array}$ & $\begin{array}{l}\text { Institutions of } \\
\text { governance to } \\
\text { fulfil colonial } \\
\text { objectives } \\
\text { The thinking } \\
\text { about governance } \\
\text { is based on } \\
\text { "direct rule } \\
\text { Centralization of } \\
\text { power at colonial } \\
\text { state territorial } \\
\text { level as part of } \\
\text { the German } \\
\text { 'Reich' }\end{array}$ & $\begin{array}{l}\text { Institutions of } \\
\text { governance to fulfil } \\
\text { colonial objectives } \\
\text { The thinking about } \\
\text { governance is } \\
\text { based on "indirect } \\
\text { rule" } \\
\text { Centralization of } \\
\text { power at the level } \\
\text { of the colonial } \\
\text { state/British } \\
\text { mandate }\end{array}$ & $\begin{array}{l}\text { Institutions of governance } \\
\text { inspired by 'independence' } \\
\text { and 'African-style democracy' } \\
\text { (ujaama) thinking } \\
\text { The thinking about } \\
\text { governance is based on } \\
\text { government planning (in } \\
\text { theory), but (in practice) a } \\
\text { transitional mix of traditional } \\
\text { and modern governance } \\
\text { practices } \\
\text { Centralization and } \\
\text { concentration of power } \\
\text { Patron-client exchanges } \\
\text { Institutions of governance } \\
\text { fused with personal } \\
\text { objectives }\end{array}$ \\
\hline $\mathrm{M}$ & $\begin{array}{l}\text { Chiefs as } \\
\text { 'heads of } \\
\text { family'. } \\
\text { Personal rule } \\
\text { based on: } \\
\text { face to face } \\
\text { exchanges; } \\
\text { unwritten, } \\
\text { traditional } \\
\text { rules; } \\
\text { shared } \\
\text { expectations; } \\
\text { strategies of } \\
\text { extraversion; } \\
\text { and } \\
\text { reciprocity } \\
\text { obligations }\end{array}$ & $\begin{array}{l}\text { Administration } \\
\text { through } \\
\text { Governors (de- } \\
\text { facto dictatorship- } \\
\text { slavery for } \\
\text { colonial rulers } \\
\text { and subjects }\end{array}$ & $\begin{array}{l}\text { "Kingship worship } \\
\text { without royal } \\
\text { powers" } \\
\text { law and order for } \\
\text { regulating and } \\
\text { disciplining } \\
\text { conduct of subjects }\end{array}$ & $\begin{array}{l}\text { Political leadership fused } \\
\text { with traditional notions of } \\
\text { family e.g. headmen, big men } \\
\text { and chiefs } \\
\text { Egalitarian political system }\end{array}$ \\
\hline
\end{tabular}




\subsection{Conclusion}

In this chapter, I have argued that current accountability practices in Tanzania need to be understood in the context of historical governmentality. I have suggested that the starting point to understand this governmentality is to examine three historical periods of pre-colonialism, colonialism and post-independence periods. Based on the three historical periods, I have argued that the three periods were characterized by different governmentalities summarised in table 5, which found their way in current accountability practices. As will be argued in the next chapters, these practices also characterized future interactions between national government officials and foreign actors on the one hand and among national government and local government officials and the society on the other. It is from this context that accountability in general and in the water sector in particular, in Tanzania will be understood. In the next chapter, I examine various institutional designs for water service provision and current accountability practices. 


\section{Institutional designs for water provision and current accountability practices}

The present accountability practices in Tanzania did not come overnight. They are a product of both pre-colonial, colonial and post-independence influences. Equally, accountability practices in the water sector bears the hallmarks of that history. Current institutions, structures, and accountability practices in Tanzania should therefore be understood within this context as explained in chapter three. In this chapter, I analyse current accountability practices at national and local government levels. First, however, I examine the different cultural meanings of water leading to different institutional hybrid designs and confusion.

\subsection{Water: what kind of a good?}

In Tanzania 'water' is a contested and therefore a politicized concept. This contestation is manifests in conflicting rationalities, mentalities and technologies attached to the concept of water. For instance, water is variously understood as private, public, and common pool good. Depending on their being formally or informally coded, beliefs can be either rationalities or mentalities. For instance, the belief that water is 'a public good' to be provided for free is a 'mentality' associated with unreflexive, cultural knowledges, to which Tanzanians once subscribed soon after attaining independence. The belief did not emanate from the representation of the individual mind or consciousness of Tanzanians, but from the bodies of knowledge and opinions that the post-independent government popularised in a quest to gain mass support and legitimacy. Yet, the belief that water is a public good to be had for a fee to cover costs to the provider is a rationality that involves a fairly systematised thinking of making calculations, and of defining purposes and employing knowledge on how much fee to collect, when and where to charge the fee. These questions translate into organisational technologies, i.e. meter reading to determine how much should be charged, invoices to bill customers and pipelines to distribute water to customers in order to know where exactly to collect the fees.

However, there are disagreements about the most proper conceptualisation of water in particular contexts. For instance, in his ethnographic case studies of establishing modern westernized drinking water provision in Arusha and two other middle-sized Tanzanian towns, Rottenberg treats 'water' as a 'marketable commodity', i.e. a rationality that subjects water to market forces of demand and supply against a price, although the people in Arusha still maintain that water is a public good to be provided for a fee. Perhaps, this can be generalized: in urban areas the political and administrative and commercial contestation around water is between these two meanings. However, a rather different contestation exists in rural areas. There, the contestation is between water as common pool resource - a lake, river, water stream, or well - where rural inhabitants go to fetch water for free; or a public good, to be had for a fee to cover costs to the provider (Wesselink, et al., 2015). When rural inhabitants fetch water for free this translate into a 'mentality' that water is a public good that should neither be subjected against a price in a market nor be had for a fee. This mentality is common among the rural dwellers in Tanzania. Thus, the fact that the concept of water centres around three contested definitions with different R-M-Ts ascribed to it, its institutional designs for its production, dissemination, and provision (at least in theory) needs to reflect that contestation.

\subsubsection{Different goods different institutional designs}

The existing socially and politically dominant views on the nature of a 'good', result into different institutional designs for their production, dissemination and provision (Wesselink et al., 2015). 
Institutions are either 'rationalities' (explicit norms and values) or organizational 'technologies' (private companies vs. public monopolies). They are rationalities because they employ rational thinking in shaping and regulating behaviour of individuals in a quest to make it predictable. In other words, institutions play a key role in formulating behavioural strategies which are critical in regulating and making behaviour legible. On the other hand, institutions are organisational technologies because they use technological apparatuses to facilitate behavioural strategies. For instance, in the case of the good as commodity, it is produced by private firms and sold to users as consumers on a market against a price, usually in the shape of a monetary transaction. Here, the market set the rules of buying and selling and regulate consumer behaviour by providing a wide range of choice on what to buy and at what price. This is usually referred to as an individualist institutional design, because (in principle) transactions are free and symmetrical between individual actors. Firms may be highly hierarchic organizations, but if there are many, consumer may freely choose to buy their product. Under certain conditions this creates a so-called 'perfect market', leading to efficient and therefore 'fair' prices (Wesselink et al., 2015). An important advantage of this rationalistic institutional design is that the price of the good is seen as coming about in an aggregative process that optimally uses contextualized knowledge of all those involved in the market for the good - producers, consumers, and those in-between.

In the case of goods as common pool resources, the main reference here is the 'mentality' that natural environments like meadows and rivers/lakes/water streams are common resources that everybody freely uses. This 'mentality' is common in cattle herding societies and economies in rural areas. As long as they are widely available as natural resources, they can lead a nomadic existence. But as population grows, people may become more constrained in their movements. If there are too many no-longer nomadic herdsmen and cattle relative to a fixed common resource pool, every individual herdsman has an interest in letting his herd graze/drink more than those of other herdsmen, and this, gradually, will erode and destroy to common resource pool. Fortunately, as well-researched and analysed by Nobel laureate Elinor Ostrom, people have been smart enough to find ways of common pool resource management. Frequently, these are very local, peer- or citizen-based systems of self-rule and self-guidance (Wesselink et al., 2015). Such systems may be referred to as community institutional designs. In such systems of human relations and practices, transactions between people are still free-members of the community make their own rules of self-guidance - but, contrary to rationalistic designs such as markets, transactions are asymmetrical. Thus, compared to markets, community designs have less 'inhabitants', and cannot disseminate so easily beyond their original limits.

Mostly, by just living somewhere, people belong to the community, obey their rules because they are part of their social fabric. In addition, they are embedded in their daily governing practices. However, due to the usually egalitarian nature of the community, there are plenty opportunities to raise their voice and demand accountability. As other community members have the same incentive, every members' uncodified or tacit knowledge is mobilized through community debates and decision-making. Thus, in this context, thinking becomes a collective activity. This may, over time, lead to changing rules, adapting to changes in the direct common pool resource environment. Through technologies of mutual monitoring, shaming and blaming, the community holds each other accountable for common resource pool use.

Finally, public goods are 'public' because, they cannot be partitioned in smaller portions (a prerequisite for selling a good); and because once made available to some, no one can be excluded 
from using or consuming it. Military defence and flood defence systems are iconic examples (Wesselink, et al., 2015). If some, affluent, members of society provide these services to themselves - they are the only ones who can afford it, they are 'natural monopolists' - all other, less affluent members cannot be excluded from also enjoying their provision. Here the major narrative is that of the free rider: instead of fairly participating in the costs of the provision of the public good by paying a proportional fee - modern states have elaborate tax systems for this function - you shirk and look the other way and still use the public good to personal advantage (Wesselink, et al., 2015).The institutional design invented to deal with free riders, of course, is the large-scale, territorially dispersed but highly coordinated and standardized 'natural' monopoly, which, by force if necessary, extracts contributory fees from everybody who objectively profits from the provision of the public good. The state or government as bureaucratic service provider represents this rationalistic hierarchist institutional design best. It is hierarchical because transactions between people are neither free nor symmetrical (ibid). They are guided by explicit norms and values which force people to participate in the system; and, depending on their rank or status, they are not free to interact freely with whomsoever you choose; you may interact with many others, but according to system-imposed rules of expected behaviour (Hoppe, 2015 unpublished work). Rules are devised by experts and the 'authorities' in the monopoly. Only centrally-rational, mobilized knowledge goes into the design of public rules as organisational technologies. This practice best represents formal reflexive thought articulated in various academic disciplines.

Against the above back drop, the institutional design for water is messy and at time confusing. For instance, in urban areas (Dar, Arusha, Dodoma, etc.), a path-dependent legacy of water as public good informs systems of urban natural monopoly by bureaucratic and water engineering professional elites, to a larger public of water consumers (Wesselink, et al., 2015). But, at the same time, New Public Management (NPM)-type reforms, pushed for by external donors on a poor government in needs of foreign aid, try to transform this hierarchical design into a market design for water as a commodity. Moreover, there already exists an 'informal water market' -or actually two such markets, one for affluent, and another one for less affluent water users (Nganyanyuka, et al., 2014). Moreover, the formal hierarchical-bureaucratic type of water provision is systemically connected to the institutionally individualist design of an informal market. The deliberate underperformance of the bureaucratic monopoly system has given rise to the functioning, in tandem, of an informal oligopolistic water market that exacts up to 25 times the price for water compared to the fee in the bureaucratic system (Nganyanyuka, et al., 2014; Wesselink, et al, 2015). The monetary surplus streams back to actors in the formal system. The link between the formal, hierarchic system, and the informal, individuals system is systemic corruption and strategies of extraversion - which itself is maintained by a coalition between highlevel state authorities and a cartel of unlawful persons and groups. All in all, in urban areas, water provision in fact is a corrupted hierarchical-individualist institutional design (Nganyanyuka, et al., 2014).

This is different again in rural areas. On the one side, the top-down, long arm of hierarchical bureaucracy reaches down to local levels by installing COWSO's for water as public good. On the other side, COWSO's are supposed (by law, paradoxically) to function as a kind of common resource pool management design, because local people are supposed not only to dutifully pay their fees, but to actively cooperate in the production and provision of water as local communities (Wesselink, et al, 2015). Thus, COWSO's are either the very local 'street-level bureaucrats' in a state-organized hierarchical scheme for local water provision, or they are pivotal 
elements in a community design for providing water as a common resource pool, freely engaging in production and provision practices and deliberating as peers about the best way to achieve wellfunctioning water points with good quality water (ibid). However, the majority of local people still maintain the 'mentality' that water is a public good to be had for free.

\subsection{Current institutional designs in the water sector}

The current institutional design for the provision of water supply and sanitation services is based on a separation between urban water supply and sewerage services and rural water supply services (Doering, 2005:46). As highlighted in the introductory remarks above, the existing institutional design for water does not have a clear cut design to accommodate the various meanings attached to the concept of water as a private, public or common pool good. Instead, the institutional design for water sector is aligned with national priorities, policies, plans and strategies reflected in the national vision 2025; millennium development goals; water policies; poverty reduction strategies; local government reform policies; foreign donor assistant strategies; water development strategies; as well as national budgets.

The Water Sector Development Programme (WSDP) -2005-2025 is the Meta programme providing institutional guidance in the management of water services in Tanzania. It is designated as a transformational programme formulated to help strengthening the capacity of the Ministry of Water to improve the quality and quantity of drinking water and sanitation services for rural and urban populations. The programme comprises three components: the Water Resources Management Programme (WRMP), the National Rural Water Supply and Sanitation Programme (NRWSSP) and the Urban Water and Sewerage Programme (UWSSP).

The Water Resources Management Programme seeks to develop a water resources management and development framework in water basins, for optimizing the utilization of the water resources in a sustainable manner (URT, 2006: ix). The National Rural Water Supply and Sanitation Programme seeks to raise coverage levels in rural areas of Tanzania to $90 \%$ by 2025 in accordance with Vision 2025 goals. In addition, it targets to provide water services to an additional 34.5 million people by 2025 (ibid: ix). The Urban Water and Sewerage Programme intends to raise water supply service coverage "from $74 \%$ (2005) to $90 \%$ in 2010 , to $95 \%$ by 2015 to meet the MDGs and to $100 \%$ to meet Vision 2025 goals. The target for sewerage coverage is to increase from $17 \%$ (2003) to $30 \%$ by 2010 . The target figures include water supply and sewerage service delivery in the city of Dar es Salaam" (URT, 2006: ix).

Notably, there are various actors (organizations, groups) in the Tanzanian water sector: the MoW, Parliament, development agencies, commercial utilities, Community Owned Water Supply Organisations (COWSOs) and NGOs. However, formal responsibility for the provision of water services rests with the MoW. For instance, by controlling authoritative resources (rule- setting power), and as the coordinator of investments within the Water Sector Development Strategy (WSDS), the Ministry strongly influences the allocation of funds (Doering, 2005; Fuhrmann et al., unpublished paper: 10). The Water Sector Development Strategy (2006-2015) is a blueprint for prioritized timely and appropriate interventions to address the water sector challenges. (URT, 2008:3).

Other actors working alongside the MoW of water include: Prime Minister's Office- Regional Administration and Local Government (PMO-RALG); Water Supply and Sanitation Authorities 
(WSSA); Energy and Water Utilities Regulatory Authority (EWURA); Ministry of Health and Social Welfare (MoHSW) Regional Secretariat; Municipal and District Councils; Village Councils; Service providers and; Community Owned Water Supply Organisations (COWSO's). The relationship between and among these actors is indicated in Figure 6 and Table 6 . The roles include undertaking decentralized responsibilities; representation; service responsibilities; regulation and monitoring; technical guidance and coordination; support supervision and monitoring; managing performance contracts etcetera.

Figure 6: Institutional framework for water supply and sanitation

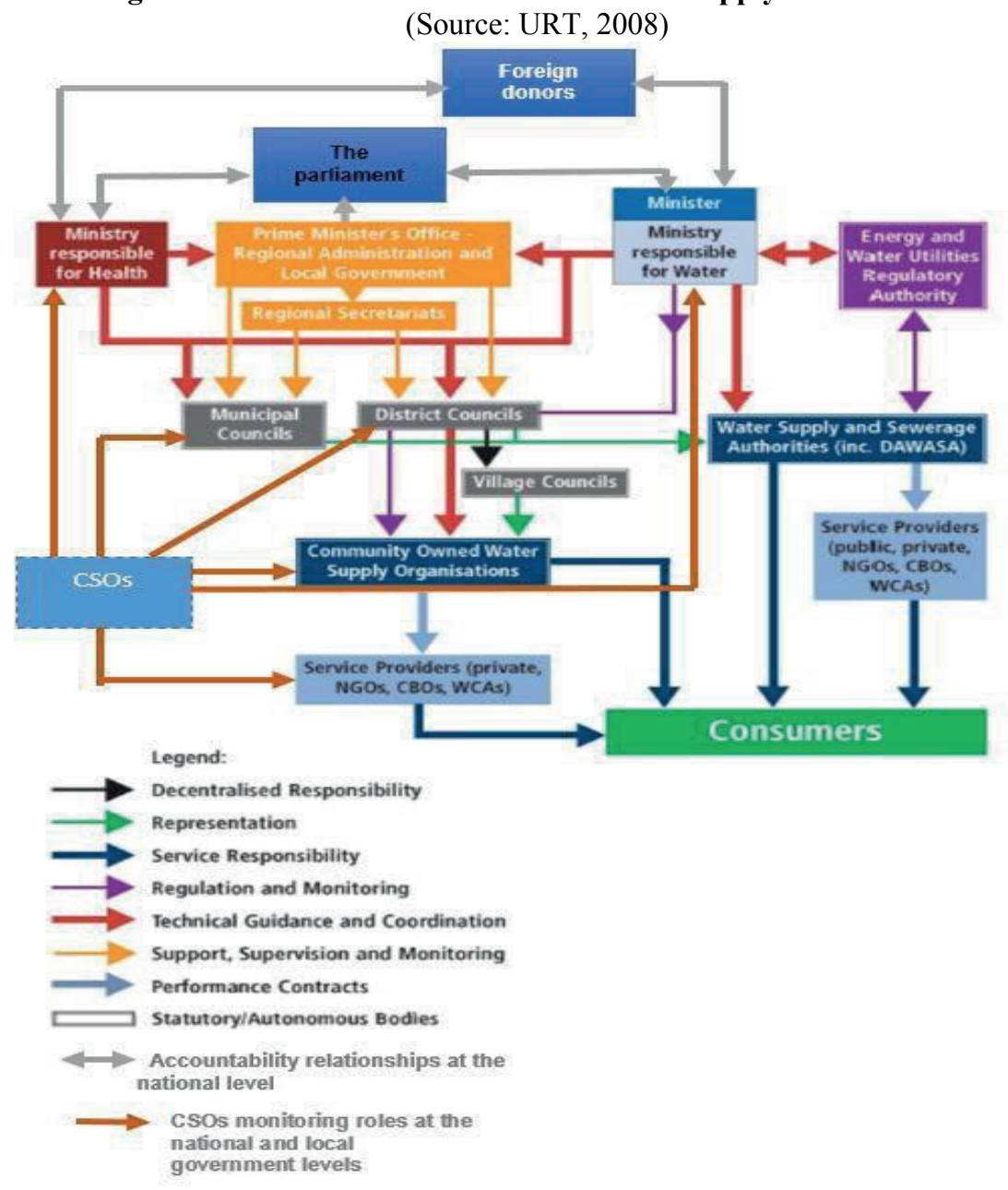

Central and local government organizations have a mandate or legal requirement to be involved in various aspects of the provision of water services. For instance, local government, at the city, municipal, town, district, or township authority level, has varying levels of responsibility for providing water supply and sanitation services to the population in their areas (ibid). The Ministry of Health and Social Welfare on the other hand has an overall responsibility for protecting public 
health through ensuring the provision of adequate sanitation and hygiene education by the local authorities. The local government authorities are ultimately accountable to the PMO-RALG (Fuhrmann et al., unpublished paper). Table 6 summaries the responsibilities of each of these actors indicated in (Table 6).

Table 6: A summary of responsibilities of actors in the water Sector, (Source: URT, 2008)

\begin{tabular}{|c|c|}
\hline Actor/institution & Responsibility \\
\hline Foreign donors & $\begin{array}{l}\text { - Funding of capacity development interventions and } \\
\text { infrastructure investments } \\
\text { - Forcing the MoW to comply on bilateral and } \\
\text { multilateral aid programme objectives } \\
\text { - Holding the MoW accountable on development aid } \\
\text { through the Water Sector Development Programme } \\
\text { (WSDP) }\end{array}$ \\
\hline Parliament & $\begin{array}{l}\text { - Performing oversight role on the MoW and other } \\
\text { institutions affiliated to the MoW }\end{array}$ \\
\hline $\begin{array}{l}\text { Minister responsible for } \\
\text { Water }\end{array}$ & $\begin{array}{ll}\text { - } & \text { Prepares and implement national sector policies and } \\
\text { strategies } \\
\text { - }\end{array}$ \\
\hline $\begin{array}{l}\text { Water Supply and Sanitation } \\
\text { Authorities }\end{array}$ & $\begin{array}{l}\text { - Own, manage and develop water supply and } \\
\text { sanitation assets. } \\
\text { - Prepare business plans to provide water supply and } \\
\text { sanitation services, including capital investment } \\
\text { plans. } \\
\text { - } \\
\text { Secure finance for capital investment, and relevant } \\
\text { subsidies. } \\
\text { - } \text { Contract and manage Service Providers. } \\
\text { - Provide services not contracted out. } \\
\text { - } \quad \text { Formulate by-laws for service provision. }\end{array}$ \\
\hline $\begin{array}{l}\text { President's Office Regional } \\
\text { Administration and } \\
\text { Government }\end{array}$ & $\begin{array}{l}\text { - Co-ordinates planning of projects from local } \\
\text { Government authorities. } \\
\text { - Co-ordinates local government authority budgets. } \\
\text { - Co-ordinates capacity building for local } \\
\text { government authorities. }\end{array}$ \\
\hline $\begin{array}{l}\text { Energy and Water Utilities } \\
\text { Regulatory Authority }\end{array}$ & $\begin{array}{l}\text { - Approves business plans and tariffs and issues } \\
\text { operating licences. } \\
\text { - Publishes technical guidelines and standards. } \\
\text { - Monitors water quality and performance. Collects } \\
\text { and publishes comparative performance data (bench } \\
\text { marking) }\end{array}$ \\
\hline
\end{tabular}




\begin{tabular}{|c|c|}
\hline Regional Secretariat & 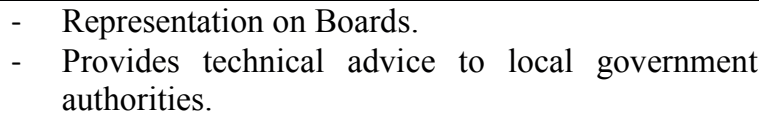 \\
\hline $\begin{array}{l}\text { Municipal and District } \\
\text { Councils }\end{array}$ & $\begin{array}{ll}\text { - } & \text { Representation on Boards. } \\
\text { - } & \text { Co-ordinate budgets within Council Budgets. } \\
\text { - } & \text { Disburse block grant funds. } \\
\text { - } & \text { Co-ordinate physical planning } \\
\text { - } & \text { Delegated performance monitoring and regulation }\end{array}$ \\
\hline Village Councils & 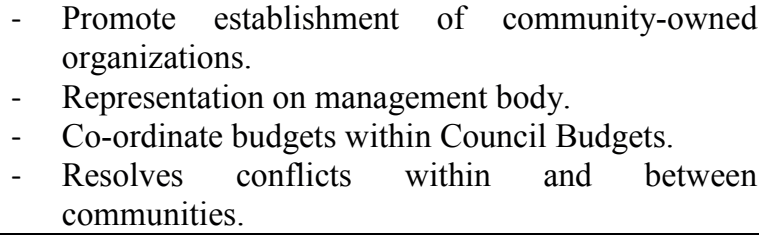 \\
\hline Service providers & $\begin{array}{l}\text { - Provide water supply and sanitation services in } \\
\text { accordance with contractual requirements. Collect } \\
\text { revenues for services. }\end{array}$ \\
\hline $\begin{array}{l}\text { Community } \text { Owned Water } \\
\text { Supply } \quad \text { Organisations } \\
\text { (COWSO’s) }\end{array}$ & $\begin{array}{ll}\text { - } & \text { Own and manage water supply assets. } \\
\text { - } & \text { Operate and maintain water supply assets. } \\
\text { - } & \text { Determine consumer tariffs. } \\
\text { - } & \text { Collect revenue for the provision of services. } \\
\text { - } & \text { Contract and manage Service Providers. }\end{array}$ \\
\hline $\begin{array}{l}\text { Ministry of Health and Social } \\
\text { Welfare (MoHSW) }\end{array}$ & $\begin{array}{l}\text { - Develops policy, guidelines and strategies for } \\
\text { sanitation. } \\
\text { - Provides technical assistance to councils for } \\
\text { sanitation. } \\
\text { - Prepares Acts, Regulations and Standards for } \\
\text { sanitation. }\end{array}$ \\
\hline $\begin{array}{l}\text { Civil Society Organisations } \\
\text { (CSOs) }\end{array}$ & $\begin{array}{l}\text { - Monitoring water service delivery at the national } \\
\text { and local government level } \\
\text { - } \quad \text { Promoting equity in service provision }\end{array}$ \\
\hline
\end{tabular}

Parliament does not have much influence on national water politics and policy implementation (Fuhrmann et al., unpublished paper: 11). The Parliamentary Committee on social service provision, including water lacks the required resources and expertise to control the activities of MoW effectively (Lawson and Rakner, 2005). 'Members of Parliament priorities are usually pinned to the electorate in their constituencies to whom they are directly accountable. The sectorwide issues are usually peripheral to them. Therefore, oversight and control of MoW through the Parliament, which would represent horizontal accountability mechanism, is limited' (Fuhrmann et al., unpublished paper: 11; Lawson and Rakner, 2005).

The international donors have probably become the most powerful actors through outside the executive. They force the MoW to comply with bilateral and multilateral agreements in the water sector. Likewise, their funding of capacity development interventions and infrastructure investments is used to drive water sector reforms under the rubric of good governance (Fuhrmann et al., unpublished paper: 11). Although, 'the power relationship between donors and the MoW has changed following the transition from a fragmented, project-based aid delivery system 
towards a harmonised, Sector-Wide Approach to Planning (SWAP), basket funding and budget support, donors still have an upper hand' (ibid).

International donors active in the water sector in Tanzania include: 'the World Bank (WB); European Union (EU); French Development Agency (AFD); the German Government-owned Development Bank-Kreditanstalt Fur Wiederaufbau (KfW); German Technical Cooperation Agency (GTZ); Millennium Challenge Corporation (MCC); Africa Development Bank (ADB); Japan International Cooperation Agency (JICA); United Kingdom Department for International Development (DFID); WaterAid; The Netherlands Development Organisation (SNV) and Netherlands Government' (African Development Bank Group Report: 2009). 'Currently, the Tanzanian Water Sector Development Program (WSDP) is the biggest program in the sector cofinanced by the Government of Tanzania (GOT), the ADB, World Bank, KfW, GTZ, Dutch Government, AFD and other financiers, valued at about USD 950 million' (ibid: 2).

The influence of donors, including that based on expert power, is exercised at the national level (through policy dialogue), where instead of assessing success or failure of individual projects, topics such as budget planning, the institutional framework, the reorganization of the bureaucracy, and questions regarding political commitment are now central to discussions between the MoW and donors (Fuhrmann et al., unpublished paper: 11). However, local government officials depend on the national level to obtain the resources needed to govern the local authorities.

Civil Society Organisations makes another layer of actors in the water sector in Tanzania. The political liberalization reforms that took place in 1992 opened the space for Civil Society Organization (CSOs) to play a critical role in scrutinizing the activities of public officials in delivering social services including, water services. Since then the role of 'CSOs has been more or less to scrutinize the executive and to articulate societal interests by contributing to political deliberations' (Fuhrmann et al., unpublished paper: 12). In particular, NGOs possess expertise and information on grassroots local realities and needs which provide them with resources and some legitimacy to exercise oversight and promote equity in service provision (ibid). Thus, the power relationship between civil society and the MoW is twofold: first, CSOs participate in the dialogue between donors and MoW; and secondly they contribute to transparency by publishing annually the water and sanitation reports which act as a source of information to members of parliament for holding the executive accountable (Fuhrmann et al., unpublished paper: 12). However, it is the international CSOs rather than the local CSOs which dominate the water landscape in Tanzania. The most notable include: the Dutch based NGO-SNV and Water Aid originating from the UK.

The current institutional design in the water sector does not capture the various meanings ascribed into the concept of water i.e. water as a public good, private good, and a common pool resource. Each good require different institutional designs for production, dissemination and provision. As a result, what is prevalent in the current set up in urban and rural areas is largely confusing. As noted above in urban areas, water provision is in fact a corrupted hierarchical- individualist institutional design which breeds systemic corruption hampering the provision of water services to the poor. In rural Tanzania the design is hierarchical-egalitarian hybrid. This design is anchored on a policy of decentralisation by devolution; meaning that the national government devolves power and authority to local governments to manage their own affairs, including water service provision. In this case local government authorities are treated by the policy as autonomous entities. The recently introduced COWSOs at the local government structure are supposed to be 
autonomous entities as well. The policy of devolution designates the central government to focus on national responsibilities and priorities of development. However, the central government is supervising the operations of the COWSOs closely, e.g. by requiring regular reports on finances and functionality. This bureaucratic capture turns COWSOs into unpaid, very local 'street-level bureaucrats'(Wesselink, et al., 2015). Conceptually, in spite of their local ownership COWSOs are therefore not an example of common-pool management, but remain within the logic of a public good (ibid). The institutional design is confusing and problematic and it brings challenges in regard to accountability practices. Next, I examine the current accountability practices at national and local government levels.

\subsection{Current accountability structures at the national government}

As reflected in most modern democratic polities, the center stage of accountability practices is at the national level. In most cases, the parliament is treated as the main center and public spectacle of national accountability practices for its accountability practices have illustrative, imitative and emblematic roles for the lower administrative units. Equally, in the spirit of the doctrine of separation of power, a tradition of three arms of government dominates democratic polities' constitutions in most countries. Here, the parliament, executive and judiciary are considered as the high level institutions of governance mandated to take control of government activities on behalf of the citizens. They are usually required to respect boundaries of each other's roles and functions for effective and efficient service delivery to the citizenry. However, the parliament maintains its key accountability role of checking on the activities of the executive. The judiciary makes sure that the laws of the land are followed and the administration of justice is effective and impartial. Tanzania is not an exception in this apparent best practice for national accountability. However, in practice, both the parliament and the judiciary have less powers vis-à-vis the president than in fully democratic systems.

The Executive of the United Republic comprises the President, the Vice-President, President of Zanzibar, the Prime Minister, the Attorney General and the Cabinet Ministers (URT, 2004:6). The President is the head of the executive branch of government. Article 33 (2) of the URT Constitution, 1977 name the President as the Head of State, the Head of Government and the Commander in Chief of the Armed Forces. Article 35(1) of the constitution mandates public officials in Tanzania to executive functions of the United Republic of Tanzania on behalf of the President (URT, 1977). Equally, article 36 (1) gives the President powers to abolish or constitute any office in the service of the Government of the United Republic while article 36 (2) gives the President the authority to appoint persons to hold positions of leadership responsible for formulating policies for departments and institutions of the Government (URT, 1977). Article 47 (1) designates the Vice President as the principal assistant of the President in respect of all the matters in the United Republic. The Prime Minister is appointed by the President and has authority over the control, supervision and execution of the day-to-day functions and affairs of the Government. Ministers and Deputy Ministers are appointed by the President after consultation with the Prime Minister. The Cabinet is the principal organ for advising the President on all matters concerning the exercise of his powers in accordance with the provisions of the Constitution (URT, 1977:36) The Attorney-General is the adviser of the Government of the United Republic on matters of law (ibid:37).

The Parliament of the United Republic of Tanzania consists of two parts: The President and the National Assembly (URT, 2004:5). The President as one part of Parliament exercise all the 
authority vested in him according to the constitution. The second part of Parliament is designated by the constitution as the principal organ of the United Republic having the authority on behalf of the people to oversee and advise the Government and all its organs in the discharge of their respective responsibilities in accordance with this Constitution (URT, 1977:39). The Judiciary branch of government consists of three organs: the Court of Appeal of the United Republic of Tanzania, the High Courts for Mainland Tanzania and Tanzania Zanzibar, the Judicial Service Commission for Tanzania Mainland, Magistrates Courts and Primary Courts (URT, 2004:7).

The Judicial Service Commission for Tanzania Mainland consists of: the Chief Justice of the Court of Appeal of Tanzania (Chairman); the Justice of the Court of Appeal of Tanzania; the Principal Judge of the High Court; and two members appointed by the President (URT, 2004:7). The national accountability structure in Tanzania also extend to include Ombudsman institutions such the Controller and Audit General (CAG); the anti-corruption body i.e. the Prevention and Combating of Corruption Bureau (PCCB), the Ethics Secretariat (EC) and the Commission for Human Rights and Good Governance (CHRGG).The Ombudsman institutions work together with the parliament in checking the activities of the executive. Civil Society Organizations (CSOs), political parties, mass media and social media play an oversight role by articulating the interests and demands of the citizens in the quest to exact accountability from public officials. International donors are crucial external actors in the national accountability structures. Their role is manifest in bilateral and multilateral aid arrangements with institutions of government, particularly the parliament and executive branches of government.

Notably, the URT constitution of 1977 concentrate a lot of powers to the executive particularly, the President as highlighted above. This constitutional practice undermine the powers and autonomy of the parliament and the judiciary. Thus, it raises challenges with regards to the role of members of parliament in performing their oversight activities on the executive. Equally, such powers extend to other important actors who are crucial in the current accountability set- up. These actors include but not limited to the media, CSOs and political parties. For instance, the URT constitution empowers a minister responsible for culture, sports and the media to deregister any news outlet on grounds of disturbing national peace and security. The same may apply to CSOs and political parties.

\subsection{Current accountability structures at the local government level}

Local governments in Tanzania were established in 1926 by British coloniser (Venogupal and Yilmaz, 2010:216). During independence in 1961, the colonial local system of administration, was continued to serve the new post independent government. However, following the need for centralization and reorganizing government along the party lines in order to meet development challenges, 'Tanzania under the one-party rule of the Tanganyika African National Union (TANU) opted for a policy of deconcentration at District and Regional levels, and abolished the elected local governments' in 1972-1973 (Kuusi, 2009:4). The policy of decentralization by deconcentration also sought to redress the urban bias in water by proclaiming a 20-year Rural Water Supply Programme (1971-1991) that aimed at providing access to adequate, safe, dependable water supply within a walking distance of 400 meters from each household (URT, 2008). Under this programme, water was provided freely by the government. A handful international donors extended support to the Programme out of which Regional Water Master Plans were prepared for all Regions (Doering, 2005:36). However, the programme largely failed to meet its targets due to non-involvement of the beneficiaries, use of inappropriate technologies, 
use of a top-down approach, and lack of decentralization (Doering, 2005:36; URT, 2008). For instance, in a mid-term review of the RWSP conducted in 1985, only $46 \%$ of the rural population had access to governmental water supply service. To rectify the situation, the government adopted the first National Water Policy in 1991, which had a number of deficiencies too and needed to be revised (Doering, 2005:36). A new water policy was formulated in 2002.

The deconcentration policy paved the way for further centralisation by substantially strengthening the powers of the regions as senior level central government staff members were transferred to the regions (Doering, 2005:36). However, because of the policy of decentralisation by deconcentration failed to achieve the intended objectives, the government re-introduced elected local governments in 1976-1982 through the Local Government (District Authorities) Act No. 7; and Local Government (Urban Authorities) Act No. 8. The two acts introduced a comprehensive system of local government authorities in rural and urban areas. The reintroduced elected councils were given direct responsibility for service delivery in the areas of primary education, primary health, local water supply, local roads, and agriculture extension (Kuusi, 2009:4). In the case of local water supply, the local councils were mandated to scrutinize the actions and inactions of the District Water Engineer (DWE), District Executive Director (DED) and the District Water and Sanitation Team (DWST) in the quest to ensure efficient delivery of rural water services.

However, the re-introduction of local government in 1976-1982 did not bring the much anticipated decentralisation of power and authority to local governments. Central government continued to centralize power and authority while devolving responsibilities without the necessary resources to local governments. In fact local government authorities turned to be a servant of central government instead of an autonomous/independent organisation. The consequences are well documented in (Mogella, 1987; Mukandala, 1998; Kiragu, 2009; and Kuusi, 2009). Some of these include: poor service delivery in water, education and health services; poor participation of people in matters that affect their wellbeing; failure to collect revenues to finance development activities within local authorities. Following this situation, in 1996 the government announced a decision to restructure the intergovernmental system and local governments in order to make the local governments more effective. Hence, the local government reform agenda and policy was formulated based on the Policy Paper on Local Government Reform of 1998 (Kuusi, 2009:4).

The newly reformed local government was based on the policy of decentralisation by devolution. According to the reforms, the responsibility for delivering public services in Tanzania Mainland is divided between the central government and local government authorities, where the regional level authority functions as an administrative and coordinating tier of the central government (Kuusi, 2009:20). The policy of decentralization by devolution envisioned local government authorities in Tanzania to be autonomous in managing their own administrative, financial, and human resources affairs within their local jurisdiction. The central government, however, maintains the responsibility of setting national priorities, policy formulation, coordination and monitoring. Figure 7 indicates the relationship between political and administrative officials at national and local levels of governance. This is highlighted in the current accountability structures at the local government levels involving political and administrative officials. 


\section{Figure 7: Political and administrative officials at national and local governments}

(Inspired by REPOA, 2008)

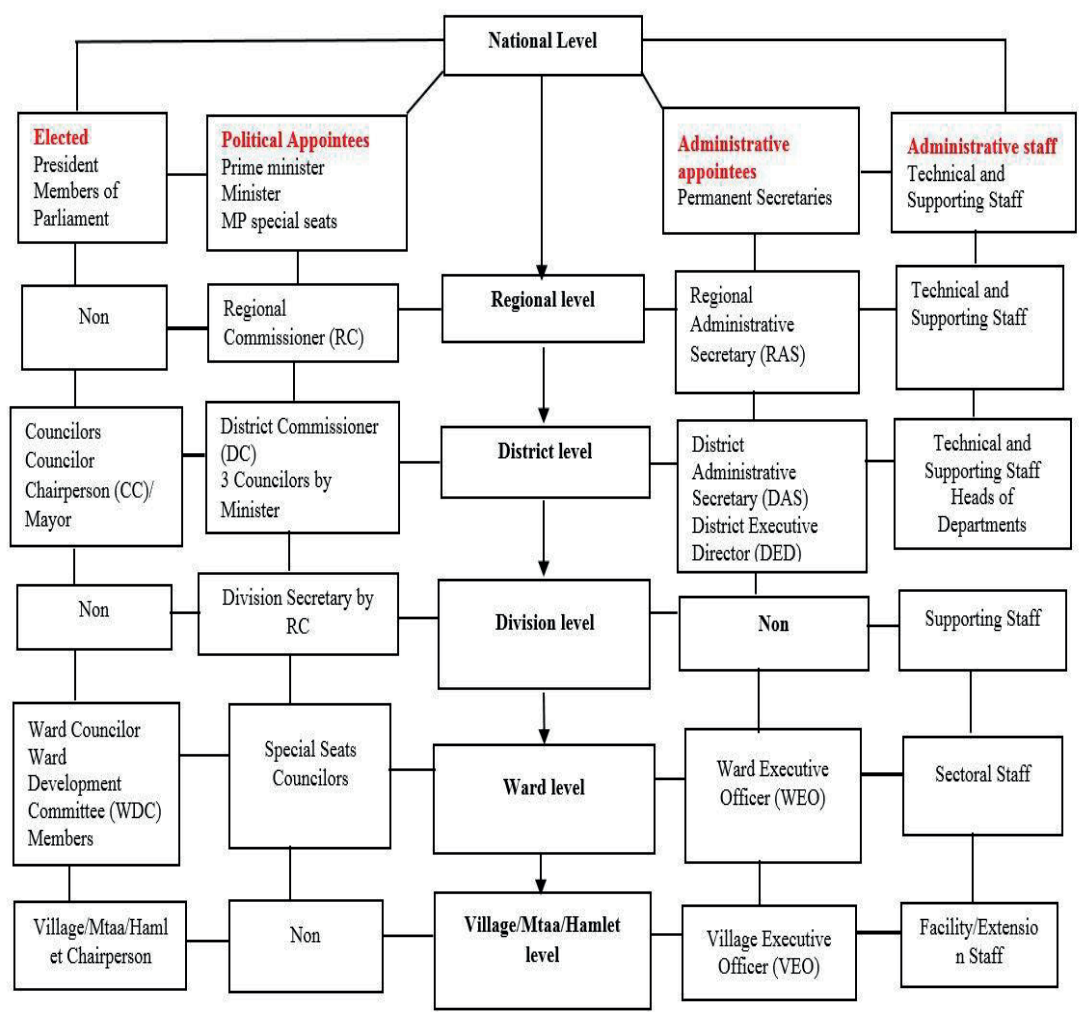

The legal basis of local government authorities in Tanzania is found in the URT Constitution of 1977 article 145 and 146 as well as the subsequent local government Acts (UNDP-UNEP, 2014:21). Article 145 of the constitution provides that local government authorities shall be established in each region, district, urban area and village in the United Republic of Tanzania (Kuusi, 2009:18). Article 146 (1) of the constitution defines the purpose of having local government authorities as 'the transfer of authority to the people'. According to the article local government authorities shall have the right and power to participate, and to involve the people, in the planning and implementation of development programmes within their respective areas and generally throughout the country' (Kuusi, 2009:18). Local Government Authorities (LGAs) are classified as rural or urban authorities. In rural areas the respective authorities are: District Councils, Township Authorities, Ward Development Committees (WDCs), Village Councils, and Vitongoji - sometimes referred to as Hamlets (Venogupal and Yilmaz, 2010: 216). Urban authorities consist of City, Municipal, and Town Councils, WDCs and Mitaa.

In rural areas, most important decisions, such as planning and budgeting are carried out at the District level (Venogupal and Yilmaz, 2010: 216). The District Council is the supreme decision making organ at the District level. Vitongoji have no legislative or decision-making powers; they operate as a forum for transmitting orders from higher level governments to the community (Venogupal and Yilmaz, 2010: 216). The elected chairperson of the Vitongoji mobilizes residents 
for development, payment of taxes, and keeping records (REPOA, 2007a cited in Venogupal and Yilmaz, 2010:216). The village assembly and the village council are the two major decision making organs of village governance.

The village assembly compose of all adult members, who elects a village council of 15-25 members as well as the council chairperson. Village assemblies do not have legislative or executive powers (Venogupal and Yilmaz, 2010:216). The village executive officer (VEO) appointed by the District Executive Director (DED) serves as a non-voting secretary to the council (ibid: 216). A village with more than 9000 residents or a district authority transitioning into town council can be classified as a township. The township authority comprises chairpersons of the vitongoji in its area, not more than three members appointed by the district council, and women appointed according to political proportionality to make up at least one- third of the authority (Venogupal and Yilmaz, 2010:217).

The ward is technically an administrative unit and not a local government unit (ibid, 217). The WDC consists of village chairpersons in the ward, all VEOs, and non-voting members invited from civil society. The WDC is responsible for coordinating development activities, planning at the ward level and linking plans with the district level. At the district level, the council consists of the elected ward councillors, members of the parliament (MPs) representing constituencies within the council, woman representatives, and other MPs whose nomination originated from organs of political parties within the district council jurisdiction(Venogupal and Yilmaz, 2010:217).

\subsection{Conclusion}

Overall, Tanzania's institutional design for accountability and water in particular is influenced by pre-colonial, colonial and post-colonial governmentalities. This presents considerable challenges to the current national and local government accountability practices. For instance, the current accountability practices at the national level place the executive at the dominant position over the parliament and the judiciary. This is made possible by the URT constitution of 1977. As noted above, this constitution concentrates powers to the executive particularly, the President. As a result, it undermines the powers and autonomy of the parliament and the judiciary. The concentration and centralization of power is an instance of African mentality that has roots in the three historical periods explained in chapter three. This raises questions with regards to the role of members of parliament in performing their oversight activities on the executive, an issue that is addressed in the next chapter.

The current local government accountability practices exhibit three forums of accountability: the district council where councillors are required to hold accountable the executives (administrative staff); and the Ward Development Committees where councillors also have to hold the administrative staff within the ward to account. Another forum includes that of Village Council where village chairpersons are supposed to hold the administrative staff at the village to account. The last forum is not considered active given the poor staffing base at the village level. However, Local Government Authorities (LGAs) face stronger incentives to provide upward accountability to higher government institutions than they do for formal downwards accountability (Venogupal and Yilmaz, 2010:216). Chapter six illustrate this assessment in the context of rural water service delivery. The legal framework also provides limited autonomy to LGAs, particularly in the absence of solid constitutional autonomy clauses, a continued financial dependence on the central state and a lack of adequate human resource management (Venogupal and Yilmaz, 2010:216). 


\section{National level accountability practices: the case of Tanzanian parliament ${ }^{21}$}

In developing countries, parliamentary accountability is a central theme on the international donor agenda and has received significant attention over the last decade. Recognizing the idea that parliament is the main forum for national accountability practices, international donors have increased their financial and technical assistance for parliamentary strengthening based on the premise that effective democratic governance depends on a professional, accountable and responsive legislature (Mandelbaum, 2011:5). This has helped donors maintain power advantage through multilateral and bilateral programs over developing countries, including Tanzania (Wang, 2005:7). Parliamentary accountability is also a recurring theme in domestic agenda for accountability based reforms. However, such accountability reforms usually depend on technical and financial support from international donors.

In view of this context, the analysis of accountability function of parliament therefore should not be taken out of the international donor-national government official's governmentality context. Notably, while international donor belief to strengthen parliamentary accountability is usually premised on rationalities, mentalities and technologies constituting formal accountability, discourses held among Members of Parliament (MP's) in Tanzania regarding accountability fall short of that. In this Chapter, therefore, I respond to the research: how MPs think of their own role of exacting accountability from the executive?. I answer this question by discussing four main accountability discourses held by MPs in Tanzania in their role of holding public officials to account. I argue that the discourses on accountability held among Tanzanian MPs enable the executive to rule in semi-autocratic ways. Even if opposition parties would obtain a parliamentary majority, this accountability culture, which represent a powerful informal undercurrent, stands in the way of achieving greater democratic representativeness. First, however, I will present a general overview of parliamentary accountability and the Tanzanian parliament in general.

\subsection{The accountability function of parliament}

Parliaments are forums in which citizen preferences are aggregated by political parties and expressed as laws and public policies (Mandelbaum, 2011: 5). It is also a forum at the epicentre of a democratic political system where accountability practices in the parliamentary arena will have an exemplary function for all other accountability chains extending to local levels of governance. In many nascent and developing democracies, the parliament may be the only institution capable of providing checks and balances that prevent the executive from monopolizing power (Mandelbaum, 2011: 5). When combined with periodic alternation in power Parliaments can be an important mechanism for government oversight, including addressing both grand and petty corruption (ibid: 5 ).

The accountability function of parliament involves a relationship between two parties: Members of Parliament (MPs) and the executive. The accountability relationship between the two parties is twofold as well: it is characterized by a relationship with the executive (horizontal accountability) on the one hand, where the executive is accountable to the MPs, and the electorate (horizontal accountability) where MPs and the executive are directly accountable to the electorate (Wang, 2005:1). Thus, MPs double their roles: holding the executive to account on behalf of the electorate and responding to the demands of the electorate and explain how the demands have been

\footnotetext{
${ }^{21}$ The contents in this chapter is based on a journal article submitted to the Journal of Modern Africa Studies (JMAS) and accepted for publication in the issue of August, 2017.
} 
accomplished. Goran Hyden calls this the 'responsive and answerability' dimensions of MPs accountability (Hyden, 2010).

Notably, the MPs are referred in this chapter as account holders whereas the executives are understood as accountors. The accountability relationship between the two is confined to a specific domain, arena or 'space' (Hyden, 2010:3). A domain is usually a specific sector or public mandate legally defined and reporting tends to follow specific parameters created by law. Arena is defined in broader political terms and has no firm boundaries and lacks a specific policy adherence (ibid: 3 ). International donors adds another layer of accountability relationships to MPs and executives. Their influence here manifest on the preference of a legally defined public mandate because it is more manageable i.e. the assumption is that an intervention into a specific 'formal' space is more feasible: it can be done (a) with less risk of accusations of interference and, (b) in ways that ensure measurable outcomes (Hyden, 2010:3). Equally, a focus on policy space allows donors to broaden their engagement to include non-state actors and broaden the context of accountability (Ibid: 3).

Another important aspect of parliamentary accountability relationship can be looked at from its external environment. Here, external factors such as political culture, external patrons, the constitution, administrative structure and the party, interest groups and electoral system are usually considered when examining parliamentary accountability (Norton and Olson, 1996:7- 9; Norton, 1998:6; Norton and Ahmed, 1999:3-6 cited in Wang, 2005:3). Likewise other peripheral but close institutions in terms of parliamentary accountability are added in this picture. The media is crucial in regard to reporting on parliamentary debates and in creating publicity and transparency about parliament's work and political processes (Wang, 2005:4). Civil Society Organisations (CSOs) actively participate in scrutinizing the parliament, including the budgetary process and various policy proposals (ibid: 4). Watchdog institutions (e.g. the ombudsman, anticorruption commission, human rights commission and the auditor general) have a bearing on parliament's accountability function as well. The office of the auditor general is crucial in regard to ex-post control of government accounts and in many countries co-operate closely with parliament (Wang, 2005:4)

The functions of members of parliament and the parliament in general varies from one country to another. In presidential democracies where MPs are elected in single-member districts using plurality rules, four core duties are typically associated with the role of the MP: legislation, executive oversight, constituency representation, and constituency service (Lindberg, 2009:119). However, where political clientelism is a prominent feature of the land scape, provision of private goods in the form of favours, personal assistance, cash handouts and so on is yet another unwritten but expected duty (ibid:119). Other than the roles of individual MPs, Parliaments perform three different functions: (i) legitimation, (ii) decisional/influence and (iii) recruitment, socialization and training (Wang, 2005:2). The 'legitimation function entails the public recognition and acceptance of the right of parliament and the executive to act in some manner, and the corresponding obligation of the citizens to abide by that action' (Copeland and Patterson 1998: xxxvii cited in Wang, 2005:3). The decisional/influence function is related to the parliament's impact on the policy-making process (Wang, 2005:3). Relatedly, the internal structuring and workings of parliament, including the committees system are significant for its ability to influence policy outcomes and thus also for it's (in) ability to hold the executive accountable (ibid: 2 ). 
The legitimation and decisional/influence functions are perceived to be of greatest importance for assessing the legislature's ability to hold the executive accountable (ibid: 2). Parliament's impact on the policy-making process is regarded by Vibeke Wang as the most important component of the decisional/influence function (Wang, 2005:2).

\subsection{The Tanzania parliament: history, composition and functions}

The Parliament of Tanzania is located in Dodoma about $454 \mathrm{~km}$ from Dar es Salaam. Dodoma is the designated national capital of the country since 1974 .

Figure 8: Map of the URT indicating the fieldwork site

(Source: http://dthd.org/who-we-are/where-we-are/)

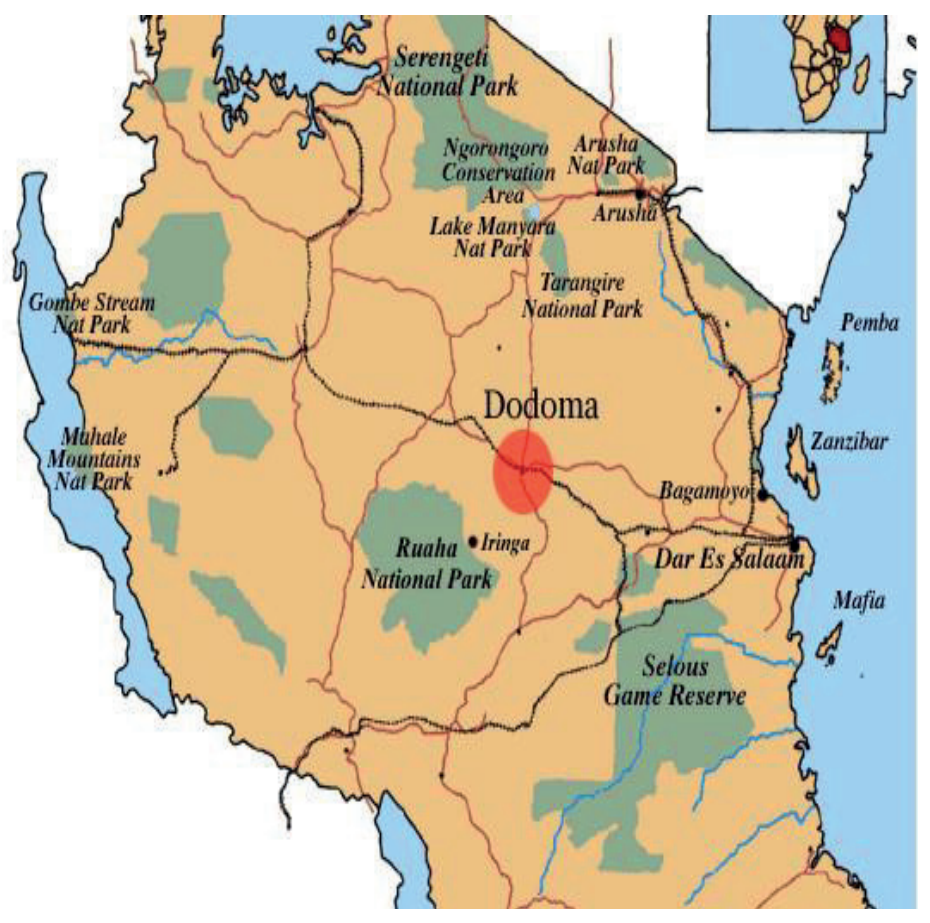

The present parliamentary institutions in Tanzania were established as the Legislative Council of Tanzania (LEGCO), by the British parliament in the Tanganyika Legislative Council Order (LEGCO) in 1926. The LEGCO was an appendage of the office of the colonial Governor (Tambila 2004). The composition of the LEGCO assured an executive-nominated majority and thus heavily favoured the executive (Matenge 2012). After attaining independence in 1961, Tanzania adopted a unicameral Westminster first-past-the-post District model in which the doctrine of parliamentary supremacy was formally emphasized (Mwakyembe 1985; Tordoff 1993; Shivji and Majamba 2004 cited in Matenge, 2012). In the Nyerere period of ujamaa (1960's-1970's) a single party system was established with Chama Cha Mapinduzi (CCM) as sole party. This led to a fusion of the presidency and the bureaucratic machinery to produce a monolithic authority, systematically articulating the executive as the de facto power centre, with parliament the de jure, but only titular, 
sovereign (Matenge 2012). Parliament was reduced to a rubber stamping institution executing its oversight role in obeisance with pre-existing informal institutions (Matenge 2012). Matenge's observation coincide with Walle, (2009) position on the state parliament in Africa regarding how informal powers dwarfed the constitutional formal powers. In this context, Walle elucidates:

\begin{abstract}
"Though many African states inherited parliamentary rule at independence, power was soon concentrated in a relatively powerful presidency, whose considerable formal powers as defined by the constitution were in fact often dwarfed by their even greater informal and de facto ones. Powers of appointment, control of the national budget, and discretion over policy implementation with little oversight was not only concentrated in the office of the presidency, it was often actually controlled by the president himself and a tiny cadre of top politicians, who were often above the law for all intents and purposes. Similarly, the executive branch dominated the other branches of government, with a subservient and pliant legislature and a weak, unprofessional and politicized judiciary" (Walle 2009: 6)
\end{abstract}

What Walle demonstrated, in the context of African parliamentary rule, is reflective of Tanzania. During the single party system, the Tanzanian parliament was controlled by the Presidency and the ruling party, CCM. However, as a result of political liberalization pressure from international donors, Tanzania formally separated the ruling party Chama Cha Mapinduzi (CCM) from the government and adopted a multiparty system in 1992 (Wang, 2005:1). This regime transition took place under the guidance of the CCM and was achieved without the upheavals associated with democratic transitions elsewhere in Africa (Wang, 2005:1). Still, this management from above gave the leadership of the ruling party the opportunity to have strong influence on the process (ibid:1).The consequence has been the vesting of tremendous powers in the executive, sacrificing the checks and balances a strong parliament could provide (Ewald 2002:5; Tripp 2000:198 cited in Wang, 2005:1). Despite the challenges, the multiparty system allowed for the first time five opposition parties obtaining a considerable number of seats ( 88 out of 357 ) in the 2010 elections.

Table 7: Parliamentary votes and seats in the 2010 union elections

(Source: Compiled from the National Electoral Commission (NEC) 2010 election data)

\begin{tabular}{|c|c|c|c|c|c|}
\hline Political party & Actual votes & $\begin{array}{l}\text { Share of } \\
\text { votes }(\%)\end{array}$ & $\begin{array}{l}\text { Directly } \\
\text { elected } \\
\text { seats }\end{array}$ & $\begin{array}{l}\text { Special } \\
\text { female } \\
\text { quarter }\end{array}$ & $\begin{array}{l}\text { Total seats } \\
\text { for each } \\
\text { party }\end{array}$ \\
\hline CCM & $4,641,436$ & 60.4 & 186 & 67 & 253 \\
\hline CHADEMA & $1,904,540$ & 24.8 & 23 & 25 & 48 \\
\hline CUF & 752,617 & 9.8 & 24 & 10 & 34 \\
\hline $\begin{array}{l}\text { NCCR- } \\
\text { Mageuzi }\end{array}$ & 193,797 & 2.5 & 4 & 0 & 4 \\
\hline UDP & 85,395 & 1.11 & 1 & 0 & 1 \\
\hline TLP & 52,608 & 0.68 & 1 & 0 & 1 \\
\hline
\end{tabular}

In the 2015 parliamentary elections results CCM obtained 188 directly elected seats and 64 special seats. For opposition political parties obtained 68 directly elected seats and 46 indirectly elected seats making a total 114 seats (NEC, 2015). This is a significant gain compared to $2010^{22}$.

${ }^{22}$ During the 2015 general elections, four opposition political parties united to form a coalition of willing dubbed as UKAWA (Tanzania Opposition Coalition for Citizen's Constitution) to challenge the ruling party . The parties included Chama Cha Demokrasia na Maendeleo (CHADEMA); Civic United Front (CUF); The National Convention 
Table 8: Parliamentary votes and seats in the 2015 elections

(Source: NEC, 2015)

\begin{tabular}{|l|r|r|r|l|l|}
\hline $\begin{array}{l}\text { Political } \\
\text { party }\end{array}$ & Actual votes & $\begin{array}{l}\text { Share of } \\
\text { Votes in (\%) }\end{array}$ & $\begin{array}{l}\text { Directly } \\
\text { elected }\end{array}$ & $\begin{array}{l}\text { Special } \\
\text { female } \\
\text { quarter }\end{array}$ & $\begin{array}{l}\text { Total seats } \\
\text { for each } \\
\text { party }\end{array}$ \\
\hline CCM & $8,021,427$ & 55.05 & 188 & 64 & 252 \\
\hline CHADEMA & $4,627,923$ & 31.75 & 34 & 36 & 70 \\
\hline CUF & $1,257,765$ & 8.63 & 32 & 10 & 42 \\
\hline ACT & 323,112 & 2.22 & 1 & 0 & 1 \\
\hline NCCR & 218,209 & 1.50 & 1 & 0 & 1 \\
\hline
\end{tabular}

There were 264 constituencies in the 2015 parliamentary elections. Although the CCM grip on power was significantly shaken the results did not fundamentally change the balance of power. The composition of the Tanzanian Parliament is not just determined by MPs elected by the Districts' electorate; these only make up 239 out of 357 seats. The constitution of the United Republic of Tanzania of 1977 (article 66) lists five categories of MPs: elected members representing individual constituencies; women members (at present $30 \%$ of all seats, allocated to parties on the basis of number of elected MPs); five MPs elected by the Zanzibar House of Representatives from among its members; the Attorney General; and ten members appointed by the President to the parliament.

Table 9: Composition of MPs in the parliament of URT

(Source: The national parliament of Tanzania www.parliament.go.tz)

\begin{tabular}{|l|r|}
\hline Type of MP & No. of MPS \\
\hline Elected MPs from constituencies & 239 \\
\hline Special seats reserved for women MPs & 102 \\
\hline Zanzibar House of Representatives MPs & 5 \\
\hline Attorney General (Ex Officio Member) & 1 \\
\hline MPs nominated by the president & 10 \\
\hline & \\
\hline total no. seats & 357 \\
\hline
\end{tabular}

This composition means that, compared to percentages of votes cast, the parliamentarian majority of the ruling party CCM is enlarged even more than is already inherent in a first-past- the-post system. This means that the President (as member of the ruling party) controls parliament if he is able to get a majority, or 179 votes. This is a doable task. At the time of fieldwork, CCM holds 253 seats while combined five opposition political parties holds 88 seats (Table 9). Even if factional struggles within CCM do not guarantee the President all $253 \mathrm{CCM}$ votes, his electoral 'slack' in parliament is $(253+11)-179=85$ seats (Table 8$)$. This is almost equal to the 88 seats of five opposition parties (CHADEMA, CUF, NCCR-Mageuzi, UDP and TLP) together (Table $9)^{23}$. Yet, this amount of 'slack' may be necessary in view of CCM's increasing internal factional struggles (Presidential Power, consulted 15 September 2015).

\footnotetext{
for Construction and Reform (NCCR-Mageuzi) and National League for Democracy (NLD). A new opposition political party (Alliance for Change and Transparency-ACT) participated in the election for the first time.

${ }^{23} \mathrm{CCM}$ - Chama Cha Mapinduzi (A revolutionary Party) CUF - Civic United Front 
Meanwhile, the frequency and amount of governance and corruption scandals has increased in recent times, deteriorating Tanzania's rankings on good governance and accountability in Africa (Mo Ibrahim Foundation, 2014). Tanzania's score on the composite accountability index lost 8.5 points between 2006 and 2013, thereby regressing towards the African mean. Although Tanzania ranks 15 th in the composite good governance index out of 52 African countries, it ranks only 24th on accountability. In this context, an enquiry about the meaning(s) of 'holding the executive accountable' amongst Tanzanian MPs is highly appropriate since this may be one of the reasons for the worsening performance ${ }^{24}$. However, before embarking on the enquiry I first present the research design used to generate the findings.

\subsection{Research design: Q-method}

The field work data presented in this chapter were collected between June and August 2015 in Dodoma and Dar es Salaam, Tanzania. In order to elicit the ways of thinking and speaking about accountability among Tanzanian MPs, my first step was to identify a suitable research design that can be used to discover and analyse the variety of opinions, perceptions, and attitudes that reflect the discourse(s) of an individual or group of individuals in a valid and reliable way. I identified Q Methodology (Brown, 1996; Stephenson, 1954) as the appropriate research tool. Q methodology claims its ancestral roots from William Stephenson in 1935 (Stephenson, 1935). The methodology offers a technique for identifying subjectivities and inter- subjectivities on beliefs, attitudes, and discourses in a particular research topic (Jeffares and Skelcher, 2011). By using a survey instrument, it retains the strengths of quantitative and qualitative methods, which enables conversion of subjective human perspectives into an objective outcome (Watts and Stenner 2005; Jeffares and Skelcher, 2011).The methodology is widely used in many subject areas, disciplines and countries (Watts and Stenner, 2012, 19-21).

In a nutshell, Q methodology involves each participant in the sample (the $\mathrm{P}$ sample) in sorting a series of statements (a Q sample) representative of the breadth of debate on an issue (the concourse) into a distribution of preference (a Q sort) from which statistically significant factors are derived and then interpreted (Jeffares and Skelcher, 2011). Unlike other forms of quantitative analysis, Q methodology does not seek to explain hypothesized causal relationships nor does it give the impression of a scientific method independent of the researcher's own interpretive skills (Ibid). This method sat down well with my research aim to discover, map and understand different MPs' discourses on accountability in Tanzania.

\subsubsection{The research procedure}

There are six main widely recognized stages to conducting a Q study (Figure 9). The first two stages are the development of a set of statements, the Q population, running into the hundreds, that somehow captures the full scope and breadth of debate on a topic, in my case MPs holding the executive accountable and being accountable to an electorate; and, second, to narrow these

\footnotetext{
CHADEMA - Chama Cha Demokrasia na Maendeleo (A party for Democracy and Development) NCCR -Mageuzi - The National Convention for Construction and Reform UDP - United Democratic Party TLP - Tanzania Labour Party

24 The findings on MPs accountability discourses presented in this chapter contribute to the research proposed by Hyden (2010) to compare the effect of different governance systems on accountability, e.g. proportional vs. first-pastthe-post systems.
} 
statements down to a manageable number of between 30 and 60 , the Q sample - while ensuring that this Q sample of statements remains representative of the diversity of opinion within the concourse.

Figure 9: Practical steps in doing $Q$ method research

(Source: Adopted and modified from Eun Ho-Ha, 2015)

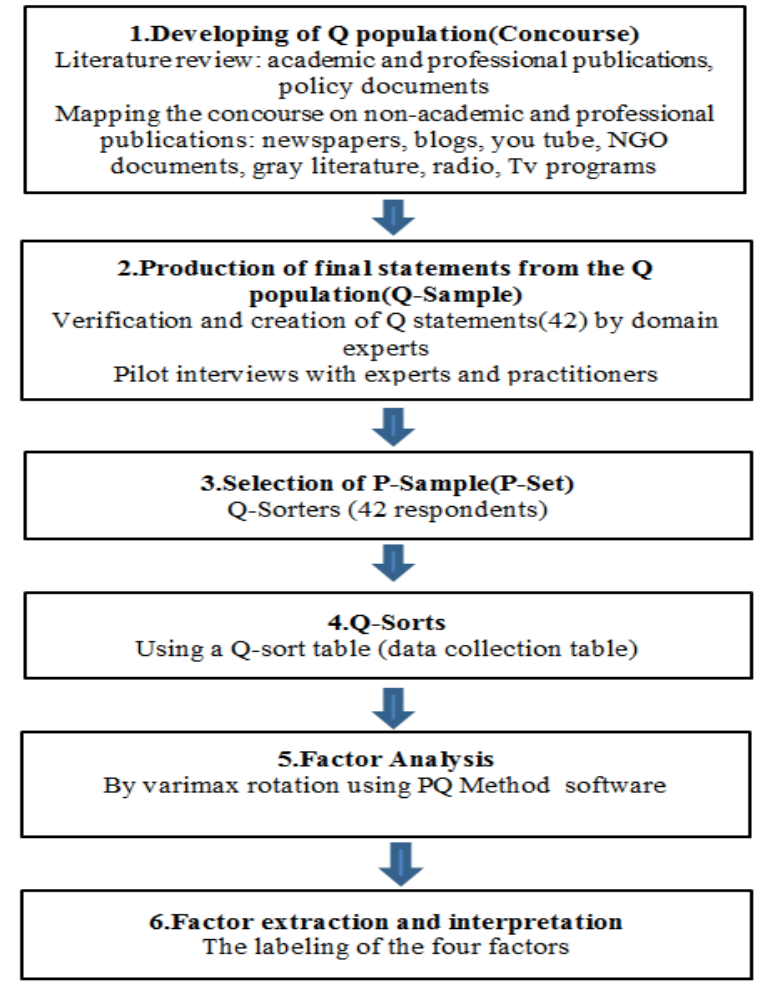

Thus, I began by developing over 150 statements from data collected in previous research, including field work reports, government and non-government reports and academic literature. I also included accountability discourses in newspapers, blogs, YouTube, radio and television programs about parliament sessions in Tanzania. The main themes found in these sources include: party organization, responsiveness, answerability, controllability, party caucus, corruption, the role of media, friendship/networks/alliances, party interests, patronage/clientelistic politics, culture, single party vs. multiparty, etc. I then eliminated overlapping and ambiguous statements, resulting in 100 statements. These statements were sent to prominent scholars (Goran Hyden and Benson Bana) for review ${ }^{25}$; this consultation reduced the list to 50 statements. A pilot

\footnotetext{
${ }^{25}$ Prof. Goran Hyden is an emeritus Professor at the Department of Political Science, University of Florida. He is a well-regarded scholar on African scholarship and has published extensively on many subjects including, political accountability in Africa. See Hyden, G. 2010. Political Accountability in Africa: is the Glass Half-Full or HalfEmpty? Power and Politics Programme (APPP). Overseas Development Institute. London. Dr. Benson Bana is a Senior Lecturer at the Department of Political Science and Public Administration, University of Dar es Salaam. He 
testing of the Q-sorting (step 4) was then conducted with three scholars (Benson Bana, Kelvin Munisi and George Jerico) working at the Department of Political Science and Public Administration, University of Dar es Salaam ${ }^{26}$. Statements were reworded where necessary, and some more were eliminated as superfluous (Ha 2015). The adequate number of statements is usually between 20-100 (Watts and Stenner 2012), depending on the researcher's estimate of how much time he may reasonably claim from respondents. Finally, 42 Q-statements (the Q-sample) were retained to represent the concourse surrounding the discourse on accountability in Tanzania Table 10.

Table 10: Standardized factor Q-sort values for each statement

\begin{tabular}{|c|c|c|c|c|c|}
\hline \multirow[t]{2}{*}{ No. } & \multirow[t]{2}{*}{ Statements } & \multicolumn{4}{|c|}{ Factors arrays } \\
\hline & & 1 & 2 & 3 & 4 \\
\hline 1. & $\begin{array}{l}\text { The interests of my political party come first before my } \\
\text { individual interests when I exercise the oversight role on the } \\
\text { executive. }\end{array}$ & -4 & 0 & 4 & -2 \\
\hline 2. & $\begin{array}{l}\text { When performing my oversight roles on the executive, I } \\
\text { usually rely on facts and reasoning rather than hearsay. }\end{array}$ & -2 & 1 & 5 & 0 \\
\hline 3. & $\begin{array}{l}\text { When exercising my oversight role on the executive, I would } \\
\text { pay attention to policy issues rather than patronage interests. }\end{array}$ & -3 & 0 & 3 & 1 \\
\hline 4. & $\begin{array}{l}\text { The existence of political factions within my party (with } \\
\text { different interests) never constrains my oversight role on the } \\
\text { executive. }\end{array}$ & -3 & -1 & 0 & -2 \\
\hline 5. & $\begin{array}{l}\text { Being loyal to my party also means than I should refrain } \\
\text { from holding the executive to account. }\end{array}$ & -4 & -3 & 0 & 0 \\
\hline 6. & $\begin{array}{l}\text { I can work with other political parties to hold the executive } \\
\text { to account without putting my party loyalty in question. }\end{array}$ & -2 & -2 & 2 & -3 \\
\hline 7. & $\begin{array}{l}\text { I think the party caucus plays a considerable role in } \\
\text { determining whether I will hold the executive accountable } \\
\text { or not. }\end{array}$ & 4 & -1 & 4 & -1 \\
\hline 8. & $\begin{array}{l}\text { My primary role as a member of parliament is to respond to } \\
\text { the demands of my electorate, including holding the } \\
\text { executive to account when they don't deliver goods to my } \\
\text { electorate. }\end{array}$ & 5 & 2 & 5 & 0 \\
\hline 9. & $\begin{array}{l}\text { I feel obliged to explain what I have accomplished to the } \\
\text { electorate, including how I accomplished it. }\end{array}$ & -5 & 1 & 3 & -3 \\
\hline 10. & $\begin{array}{l}\text { The "friendship" factor weakens my party, including my } \\
\text { ability to demand accountability from the executive. }\end{array}$ & -1 & -5 & -1 & 1 \\
\hline 11. & $\begin{array}{l}\text { The current URT constitution and its common practical } \\
\text { interpretation give too much power to the president and the } \\
\text { executive over the parliament. }\end{array}$ & 5 & 4 & 0 & -1 \\
\hline
\end{tabular}

has written widely on many topical areas in Tanzania including, issues of accountability. See Bana B, and McCourt, W. 2006. 'Institutions and Governance: Public Staff Management in Tanzania', Public Administration and Development 26, 395-407

${ }^{26} \mathrm{Mr}$. Kelvin Munisi is a PhD Student at Konstanz University, Germany and Assistant Lecturer at the Department of Political Science and Public Administration, University of Dar es Salaam. Mr. George Jerico is an Assistant Lecturer at the Department of Political Science and Public Administration, University of Dar es Salaam 


\begin{tabular}{|c|c|c|c|c|c|}
\hline 12. & $\begin{array}{l}\text { It is logical to pretend to hold the executive to account } \\
\text { during election times because I am worried about re- } \\
\text { election. }\end{array}$ & 2 & -3 & -3 & -3 \\
\hline 13. & $\begin{array}{l}\text { Live television/radio coverage on parliamentary debates } \\
\text { strengthens my oversight role on the executive because I can } \\
\text { score political points for the electorate. }\end{array}$ & 0 & -2 & -1 & -1 \\
\hline 14. & $\begin{array}{l}\text { Debating on corruption is merely a political façade to show } \\
\text { the electorate that I am holding the executive to account. }\end{array}$ & 4 & -3 & -4 & -2 \\
\hline 15. & If I 'smell' corruption, I always try to go to the bottom of it. & 3 & 5 & 4 & 1 \\
\hline 16. & $\begin{array}{l}\text { I would threaten the executives with tough oversight only as } \\
\text { a political leverage to get goods for my electorate and wealth } \\
\text { for myself. }\end{array}$ & 3 & -3 & -1 & 3 \\
\hline 17. & $\begin{array}{l}\text { The media pay a lot of attention to corruption, but their } \\
\text { politically biased reporting never influences my own } \\
\text { political judgment in accountability issues regarding the } \\
\text { executive. }\end{array}$ & 2 & 0 & 1 & -3 \\
\hline 18. & $\begin{array}{l}\text { Using court injunctions, executives can easily evade serious } \\
\text { debate about accountability issues in the parliament. }\end{array}$ & 1 & 3 & -5 & 0 \\
\hline 19. & $\begin{array}{l}\text { Religious leaders in Tanzania speak a lot against corruption } \\
\text { but their religiously biased views never influence my own } \\
\text { political judgment in accountability issues regarding the } \\
\text { executive. }\end{array}$ & -2 & 1 & 2 & -1 \\
\hline 20. & $\begin{array}{l}\text { When I debate in the parliament, I would not worry much } \\
\text { about my loyalty to my party or effective deliberations. }\end{array}$ & 2 & -1 & 1 & 1 \\
\hline 21. & $\begin{array}{l}\text { The Tanzanian society at large is not socialised to give } \\
\text { account on one's actions/inactions and neither is the } \\
\text { executive. }\end{array}$ & 4 & 3 & 1 & 2 \\
\hline 22. & $\begin{array}{l}\text { In my opinion, the introduction of a multiparty system } \\
\text { deteriorated possibilities for MPs to hold the executive } \\
\text { accountable compared to the single party system during } \\
\text { Nyerere. }\end{array}$ & -1 & -4 & -1 & -2 \\
\hline 23. & $\begin{array}{l}\text { Without investigative journalism in the media, I would be } \\
\text { unable to do a good job as MP in demanding accountability } \\
\text { from the executive. }\end{array}$ & 0 & 1 & 0 & 5 \\
\hline 24. & $\begin{array}{l}\text { My oversight role on the executive is compromised when I } \\
\text { look for external sources of funding to meet the demands of } \\
\text { my electorate. }\end{array}$ & 1 & -1 & -2 & 2 \\
\hline 25. & $\begin{array}{l}\text { If I get the right information on the actions and inactions of } \\
\text { executives, I will hold them to account. }\end{array}$ & -1 & 2 & 3 & 1 \\
\hline 26. & $\begin{array}{l}\text { The culture of the executive to protect each other during } \\
\text { "scandals" in the parliament constrains my ability to demand } \\
\text { accountability from the executive. }\end{array}$ & 1 & -1 & -2 & 4 \\
\hline 27. & $\begin{array}{l}\text { If I am a member of the opposition political party, I am more } \\
\text { likely to be taken seriously when I demand accountability } \\
\text { from the executive compared to members of the ruling party. }\end{array}$ & -5 & 0 & -3 & -4 \\
\hline 28. & $\begin{array}{l}\text { When election time approaches, controversial bills are } \\
\text { tabled by the executive before the parliament because they }\end{array}$ & 3 & 3 & -4 & 2 \\
\hline
\end{tabular}




\begin{tabular}{|c|c|c|c|c|c|}
\hline & $\begin{array}{l}\text { know we will be paying more attention to re-election than } \\
\text { the tabled bill. }\end{array}$ & & & & \\
\hline 29. & $\begin{array}{l}\text { During election time, the executive will increase allowances } \\
\text { and retirement benefits for us as a means to control our } \\
\text { oversight roles. }\end{array}$ & 2 & 2 & -3 & 4 \\
\hline 30. & $\begin{array}{l}\text { My oversight role over executives becomes effective when } \\
\text { I base my arguments on Nyerere's ideals. }\end{array}$ & -2 & -4 & 0 & -4 \\
\hline 31. & $\begin{array}{l}\text { I am required by parliamentary and party rules to attend to } \\
\text { the demands of the electorate regardless of whether they are } \\
\text { private or community based. }\end{array}$ & -3 & 0 & -2 & -4 \\
\hline 32. & $\begin{array}{l}\text { My oversight role on the executive is constrained by the fact } \\
\text { that the speaker of the parliament uses majority MPs from } \\
\text { the ruling party to pass controversial bills. }\end{array}$ & 1 & 4 & -5 & 0 \\
\hline 33. & $\begin{array}{l}\text { During election time I usually pay more attention to my } \\
\text { constituency than holding the executive to account. }\end{array}$ & -1 & -2 & 1 & 3 \\
\hline 34. & $\begin{array}{l}\text { I think the mixed presidential and parliamentary system of } \\
\text { government promotes the oversight role of MPs in Tanzania. }\end{array}$ & 0 & -2 & 0 & 0 \\
\hline 35. & $\begin{array}{l}\text { If CAG reports implicate the executive on any malpractices, } \\
\text { I will hold the executive to account. }\end{array}$ & 3 & 5 & 2 & 1 \\
\hline 36. & $\begin{array}{l}\text { In my opinion the PAC is the most active and capable } \\
\text { parliamentary committee in holding the executive to } \\
\text { account. }\end{array}$ & 0 & 4 & 1 & 4 \\
\hline 37. & $\begin{array}{l}\text { In my opinion all parliamentary committees are effective } \\
\text { platforms for holding the executive to account. }\end{array}$ & 0 & 2 & 2 & 3 \\
\hline 38. & $\begin{array}{l}\text { My oversight role is constrained by the fact that my fellow } \\
\text { MPs from the same political party are also ministers. }\end{array}$ & -3 & -4 & -2 & -5 \\
\hline 39. & $\begin{array}{l}\text { I cannot hold the executive to account because I am an } \\
\text { appointed MP. }\end{array}$ & -4 & -5 & -4 & -5 \\
\hline 40. & $\begin{array}{l}\text { During budgetary sessions powerful interests bribe MPs to } \\
\text { pass budgets for given ministries; this constrains my ability } \\
\text { to hold the executive to account. }\end{array}$ & 1 & 3 & -3 & 5 \\
\hline 41. & $\begin{array}{l}\text { Some of the parliamentary rules and procedures hinder my } \\
\text { ability as an MP to hold the executive to account, e.g. the } \\
\text { majority decides. }\end{array}$ & -1 & 0 & -1 & 3 \\
\hline 42. & $\begin{array}{l}\text { The fact that I have impunity when I am in the parliament, I } \\
\text { don't fear to hold the executive to account. }\end{array}$ & 0 & 1 & 3 & 2 \\
\hline
\end{tabular}

The third step was to sample from the population of 357 MPs (the P-sample). Q-method requires a smaller response $\mathrm{N}$ than other forms of quantitative analysis, because the purpose of the $\mathrm{P}$ sample is not representativeness for generalizability, but to map the diversity of opinions (Watts and Stenner 2012: 72). Given the nature of Q-method, the only sampling rule is to have a number of participants that is smaller than the number of statements in the Q-sample. This number being 42 , I decided that $10 \%$ or 35 MPs of the 357 -seat parliament would be sufficient. To avoid bias as much as possible, I tried to get a good spread amongst our participants on the following criteria: seniority in the parliament, i.e. first-time, second or third term MP; gender; age; rural- urban divide; Zanzibar-mainland divide; type of MP i.e. elected or appointed; as well as opposition party vs ruling party (Table 11). 
Table 11: Q-sort participants' characteristics $(\mathbf{N}=\mathbf{3 5})$

\begin{tabular}{|c|c|c|c|c|c|c|}
\hline Variables & $\begin{array}{l}\text { Cluster } \\
1(n=8)\end{array}$ & $\begin{array}{l}\text { Cluster } \\
2(n=9)\end{array}$ & $\begin{array}{l}\text { Cluster } \\
3(n=6)\end{array}$ & $\begin{array}{l}\text { Cluster } 4 \\
(n=4)\end{array}$ & $\begin{array}{l}\text { Double loaders } \\
(n=4)\end{array}$ & $\begin{array}{l}\text { Non Loaders } \\
(\mathrm{n}=4)\end{array}$ \\
\hline \multicolumn{7}{|c|}{ Gender } \\
\hline Males & 6 & 5 & 5 & 3 & 1 & 2 \\
\hline Females & 2 & 4 & 1 & 1 & 3 & 2 \\
\hline \multicolumn{6}{|c|}{ Age } & \\
\hline In years & $38-45$ & $50-58$ & $28-38$ & $45-58$ & $38-58$ & $38-58$ \\
\hline range & & & & & & \\
\hline \multicolumn{7}{|c|}{ Education } \\
\hline $\begin{array}{l}\text { University } \\
\text { degree }\end{array}$ & 3 & 4 & 3 & 1 & 0 & 0 \\
\hline Diploma & 2 & 3 & 1 & 0 & 2 & 3 \\
\hline $\begin{array}{l}\text { Secondary } \\
\text { education }\end{array}$ & 3 & 2 & 2 & 3 & 2 & 1 \\
\hline $\begin{array}{l}\text { Primary } \\
\text { education }\end{array}$ & 0 & 0 & 0 & & 0 & 0 \\
\hline \multicolumn{7}{|c|}{ Seniority in parliament } \\
\hline $\begin{array}{l}1^{\text {st }} \text { term } \\
\text { MPs }\end{array}$ & 3 & 3 & 4 & 1 & 0 & 0 \\
\hline $\begin{array}{l}2^{\text {nd }} \text { term } \\
\text { MPs }\end{array}$ & 3 & 5 & 4 & 2 & 3 & 2 \\
\hline $\begin{array}{l}3^{\text {rd }} \text { term } \\
\text { MPs }\end{array}$ & 2 & 1 & 1 & 1 & 1 & 2 \\
\hline \multicolumn{7}{|c|}{ Nature of political party } \\
\hline $\begin{array}{l}\text { Ruling } \\
\text { party }\end{array}$ & 5 & 4 & 4 & 3 & 2 & 3 \\
\hline $\begin{array}{l}\text { Opposition } \\
\text { parties }\end{array}$ & 3 & 5 & 2 & 1 & 2 & 1 \\
\hline \multicolumn{7}{|c|}{ MP orientation } \\
\hline Elected & 6 & 7 & 6 & 3 & 2 & 3 \\
\hline Appointed & 1 & 1 & 0 & 0 & 0 & 0 \\
\hline $\begin{array}{l}\text { Special } \\
\text { seats }\end{array}$ & 1 & 1 & 0 & 1 & 2 & 1 \\
\hline \multicolumn{7}{|c|}{ Rural/urban representation } \\
\hline Rural & 3 & 3 & 2 & 2 & 1 & 2 \\
\hline Urban & 5 & 6 & 4 & 2 & 3 & 2 \\
\hline \multicolumn{7}{|c|}{ Mainland vs. Zanzibar divide } \\
\hline Mainland & 7 & 9 & 5 & 4 & 4 & 4 \\
\hline Zanzibar & 1 & 0 & 1 & 0 & 0 & 0 \\
\hline
\end{tabular}

The fourth step is to ask respondents to sort the statements into order of preference, giving them a specific instruction, such as 'agree/disagree' or 'most like/most unlike'. Approaches to sampling depend on the topic under investigation, and may utilise purposive, naturalistic or 
demographically representatives samples. Participants then undertake a more refined sort by placing each statement into a forced distribution prescribed by the researcher, often a semi-Normal distribution ranging from -4 to +4 or -5 to +5 , depending on the number of statements Figure 12 . This forces participants to rank statements relative to each other, rather than only agreeing or disagreeing. The basic assumption of this survey technique is that statements gain credibility if weighed off against each other, and that stronger statements (e.g. $+5,-5)$ are fewer than more moderate or neutral statements.

Figure 10: Fixed distribution of the Q-set
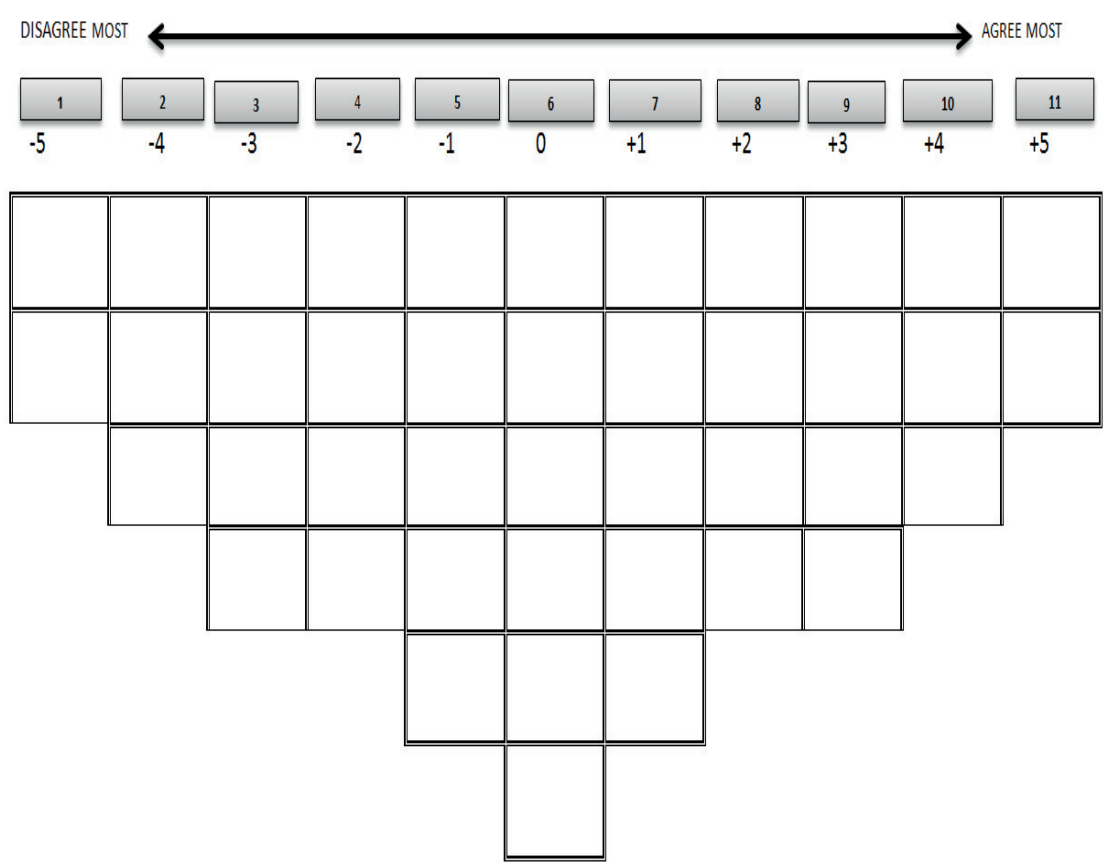

In each encounter, the researcher approached MPs in the parliamentary grounds during breaks. During these breaks, MPs would go for tea and lunch in a restaurant located few meters from the main building. A generous parliamentary administrative official introduced the researcher to several MPs. This approach was useful but challenging. It was useful because this was a convenient opportunity to interact with MPs right away, or ask for an appointment. The challenge was that the research coincided with the 2015 national elections period. MPs were focused on how to be re-elected; they were busy on phones talking to supporters in their electorate, or live with visitors representing constituencies. This pressure prevented some MPs from accepting interview appointments. Unexpected cancellation of interviews and unanswered follow-up phone calls were some of the other hurdles. In addition, one day after the researcher arrived at the parliament 43 opposition members were expelled by the speaker following their objection on a bill tabled by the government under a certificate of urgency. This meant more time was needed to track opposition members for interviews. 
In each meeting, participants were informed of ethical considerations (see section 4.4.2 below). The participants were instructed to randomly pick Q-sort cards and sort the statements into three piles: agree, disagree and neutral. Subsequently, they ranked the statements into an 11-way matrix Figure 11. After this Q-sort, respondents were interviewed to explain the sorting. These recorded interviews helped to interpret the findings in later stages of analysis.

In the fifth step Principal Component Analysis (PCA) was performed on the ensemble of Qsorts to reveal patterns in the data, using PQ-method software (Schmolck, 2014). This yields clusters (or groups) of participants with the most similar statement rankings ('factors' in Qmethod jargon). Based on the eigenvalues $(>1.000)$ the statistical procedure initially derived 8 factors. Using Scree and Humphrey's tests (Watts and Stenner, 2012, 107-8) and researchers' judgment, four clusters were chosen for a VARIMAX rotation using statistical criteria (Table 12). While other numbers of clusters were also significant, I opted to distinguish four clusters because they appeared eminently interpretable (see section 4.5).

Table 12: Inter-correlation matrix between factor scores

\begin{tabular}{|r|r|r|r|r|}
\hline & 1 & 2 & 3 & 4 \\
\hline 1 & 1.0000 & 0.3015 & -0.0787 & 0.4347 \\
\hline 2 & 0.3015 & 1.0000 & 0.2719 & 0.4457 \\
\hline 3 & -0.0787 & 0.2719 & 1.0000 & 0.0959 \\
\hline 4 & 0.4347 & 0.4457 & 0.0959 & 1.0000 \\
\hline
\end{tabular}

In addition, the inter-correlation matrix (Table13) shows the four factors to be well distinct (max. correlation is 0.4457); there are no strict consensus statements; the spread of individual respondents statistically loading on the four factors (minimum loader is a high .6380) is well balanced ( $\mathrm{N}=8,9,6,4$ respectively) with just 4 confounding loaders and 4 non-loaders; the accumulated explained variance is a satisfactory $61 \%$. Subsequently, each participant's ranking was transformed into a factor loading, signalling the degree to which an individual's ranking corresponds to the averaged rankings of the four principal factors, the so-called factor array (Table 13). As Brown (1996) advises, weighted averaging of the scores was used to calculate each factor's (cluster's) standardised average rating for each statement (Table 13). 
Table 13: Factor matrix with $X$ indicating a defining $\operatorname{sort}(\mathrm{N}=35)$

\begin{tabular}{|c|c|c|c|c|}
\hline QSORT & 1 & 2 & 3 & 4 \\
\hline 1 00RESP1 & 0.2278 & 0.5718 & 0.1125 & 0.5258 \\
\hline 2 00RESP2 & 0.0118 & $0.8807 \mathrm{X}$ & 0.0252 & 0.0230 \\
\hline 3 00RESP3 & -0.1649 & $0.6380 \mathrm{X}$ & -0.0122 & 0.1863 \\
\hline 4 00RESP4 & 0.0303 & $0.8112 \mathrm{X}$ & 0.0842 & 0.0832 \\
\hline 5 00RESP5 & 0.2242 & $0.6135 \mathrm{X}$ & 0.1782 & 0.1941 \\
\hline 6 00RESP6 & 0.1714 & 0.5763 & 0.5483 & -0.1138 \\
\hline 7 00RESP7 & 0.2116 & $0.8020 \mathrm{X}$ & 0.1302 & 0.1394 \\
\hline 8 00RESP8 & 0.1948 & $0.7022 \mathrm{X}$ & 0.1100 & 0.4571 \\
\hline 9 00RESP9 & 0.4275 & 0.4295 & 0.1563 & 0.2710 \\
\hline 10 00RESP10 & -0.1248 & -0.1531 & $0.7030 \mathrm{X}$ & -0.1000 \\
\hline 11 00RESP11 & 0.2183 & $0.5275 X$ & -0.0400 & -0.3520 \\
\hline 12 00RESP12 & -0.0899 & 0.1532 & $0.7128 \mathrm{X}$ & 0.1073 \\
\hline 13 00RESP13 & 0.0273 & 0.0094 & $0.7590 \mathrm{X}$ & 0.1172 \\
\hline 14 00RESP14 & 0.1146 & 0.2472 & $0.4909 X$ & -0.3705 \\
\hline 15 00RESP15 & -0.2218 & 0.2129 & $0.7196 \mathrm{X}$ & -0.0592 \\
\hline 16 00RESP16 & 0.3964 & 0.3011 & -0.0103 & 0.3997 \\
\hline 17 00RESP17 & 0.3261 & 0.4373 & -0.0552 & 0.3071 \\
\hline 18 00RESP18 & 0.3013 & $0.6204 \mathrm{X}$ & 0.2148 & 0.4211 \\
\hline 19 00RESP19 & 0.2298 & 0.3669 & 0.2857 & $0.6452 \mathrm{X}$ \\
\hline 20 00RESP20 & 0.2181 & 0.2793 & 0.2527 & $0.6000 \mathrm{X}$ \\
\hline 21 00RESP21 & 0.1369 & 0.4608 & $0.6278 \mathrm{X}$ & 0.2431 \\
\hline 22 00RESP22 & 0.3225 & 0.4505 & 0.2795 & 0.4703 \\
\hline 23 00RESP23 & 0.1838 & $0.5912 \mathrm{X}$ & 0.1899 & 0.2824 \\
\hline 24 00RESP24 & $0.7176 \mathrm{X}$ & 0.0159 & -0.1415 & 0.4478 \\
\hline 25 00RESP25 & 0.1099 & 0.1510 & -0.0401 & $0.7293 \mathrm{X}$ \\
\hline 26 00RESP26 & 0.1812 & 0.0925 & -0.1537 & $0.7672 \mathrm{X}$ \\
\hline 27 00RESP27 & $0.8556 \mathrm{X}$ & 0.1001 & 0.0065 & 0.0298 \\
\hline 28 00RESP28 & 0.5596 & 0.1632 & 0.0324 & 0.5614 \\
\hline 29 00RESP29 & $0.8745 \mathrm{X}$ & 0.1048 & -0.0625 & 0.0654 \\
\hline 30 00RESP30 & 0.5673 & 0.1210 & -0.2123 & 0.5322 \\
\hline 31 00RESP31 & $0.5501 X$ & 0.2042 & -0.1671 & 0.3790 \\
\hline 32 00RESP32 & $0.6994 X$ & 0.2322 & 0.0377 & -0.0966 \\
\hline 33 00RESP33 & $0.7261 X$ & -0.0361 & 0.0946 & 0.0906 \\
\hline 34 00RESP34 & $0.7484 X$ & 0.1953 & -0.0704 & 0.3767 \\
\hline 35 00RESP35 & $0.7016 \mathrm{X}$ & 0.1644 & -0.0851 & 0.4538 \\
\hline \% expl.Var. & 18 & 19 & 10 & 14 \\
\hline
\end{tabular}


The sixth and final step is for the researcher to interpret the results. This task was assisted by asking respondents to discuss the reasoning behind their preferences once they had completed the Q-sort (Jeffares and Skelcher 2011). The discussions were largely conducted in Swahili and quotes below (see section 4.4) are translated to English.

\subsection{Findings}

Using Q-method research as explained above, I found four clearly identifiable discourses on accountability amongst Tanzanian MPs: 'Partycrats'; 'My Electorate's Advocates; 'Frustrated Account Holders'; and 'Pragmatic Account holders'. I understand these discourses within the context of governmentality and I argue that this combination of discourses, or accountability culture, enables the executive to rule in semi-autocratic ways. Even if opposition parties would obtain a parliamentary majority, this accountability culture stands in the way of achieving greater democratic representativeness. The international donor driven accountability reforms are also likely to fail if these discourses are not taken as part of the accountability agenda. The four clusters distinguished in the Q-sort are captured by the following labels: My Electorate's Advocates (MEA), Party Crats (PC), Frustrated Account Holders (FAH), Pragmatic Account Holders (PAH). The following elaborates their Q-sort and interprets the clusters in the context of Tanzanian governance.

\subsubsection{My Electorate's Advocates (MEA) "My electorate is my family"}

This cluster is the second largest one and consists of eight MPs; it is dominated by males (6M$2 \mathrm{~F}$ ) and the ruling party (5) is better represented than the opposition parties (3). Although they are relatively young (38-45) years), they are highly experienced: only 3 are first-term MPs (who, meanwhile, also have 5 years of experience since elections were imminent); all others are in their second or third term.

MPs in this cluster put primacy on the electorate of their own districts. They feel that the main role of an MP is to respond to the demands of their own electorate (statement \#8 scores +5 ; abbreviated to \#8+5). Accordingly, they mainly try to hold the executive to account when it fails to deliver goods and services to their electorates. As a logical consequence this group of MPs rejects the statement that the interests of their political party come first, before individual interests (\#1-4). However, the allegiance to their electorate is not matched with a perceived need to explain to the electorate how they deliver goods and services (\#9 -5). This is in line with their belief that Tanzanian society at large is not socialized to give account on actions/inactions and neither is the executive $(\# 21+4)$. To note that the other three clusters also support this belief, but more weakly PC $(\# 21+1$; PAH \#21 +2; FAH \#21 +3): 'Tanzanians in my constituency want to see schools, functional water wells, good roads, good prices for agriculture produce etc. They are not interested to know how I managed to deliver these services. A member of parliament is like a father in a family. He is supposed to bring food on the table. Children are not supposed to question how much did the father pay for the food, it is none-of their business.'

This may mean that these MPs justify engaging in corrupt endeavours to obtain the resources to deliver goods and services. Indeed, this cluster rejects the statement that when exercising oversight roles on the executive, it is justified to let patronage interests prevail over policy issues (\#3 -3). Furthermore, debates about corruption by this group of MPs are considered a political façade to show the electorate that the executive is being held accountable $(\# 14+4)$. All three 
other clusters strongly reject this statement (PAH -2; FAH -3; PC -4). Having no confidence in the URT constitution, which gives too much powers to the president and the executive over the parliament $(\# 11+5)$, may explain why these MPs think only through the electorate that the executive may be held accountable.

The MPs also rejects the statement that when performing oversight roles, they would rely on facts and reasoning rather than hearsay (\#2 -2). Only this cluster rejects this statement. This implies that in this cluster the Nyerere ideals of ujamaa socialism in general are no longer influential on MPs oversight roles over the executive (\#30 -2): 'Nyerere does not bring development to my constituency, he is long dead, but he is still very respected [...] What matters now is who is currently in power, that's the one we should be dealing with, including his government. A person that can give you hope is the one that you can see and talk to physically, not an imagined one.'

MPs in this cluster do not see any constraints preventing appointed MPs from holding the executive to account, strongly rejecting statements that they cannot hold the executive to account because of being an appointed MP (\#39 -4) and related statements (\#27-5; \#38-3). For instance, they rejected the statement that an opposition MP is more likely to be taken seriously when demanding accountability from the executive (\#27-5). They also rejected the statement that 'MP's oversight role is constrained by the fact that fellow MPs from the same political party are also ministers' (\#38-3). In a nutshell the MEA MPs' take on accountability may be summarized as follows: my allegiance is solely to my district's electorate and this is where I hold the executive to account.

\subsubsection{Party Crats (PC)}

\section{"Party first, individuals later"}

This cluster consists of 6 MPs. It is a very young (ages 28-38) male-dominated (5M - 1F) and rather inexperienced group of MPs, with most of them in their first term. The cluster consists of both ruling party (4) and opposition party MPs (2).

In their choice of statements, this cluster has few overlaps with other clusters. The MPs in this cluster believe that only the party can hold the executive to account. Both opposition and ruling party MPs in this cluster strongly confirm the statement that the interests of their respective political party comes first, before their individual interests, when exercising oversight roles $(\# 1+4)$ : 'In our party we have a party creed that goes like this: 'party first, individuals later'. No one is bigger than the party, including the president who also serves as the chairman of the party. If the party decides on an issue no member can decide otherwise' (MP ruling party). 'Party caucus plays a great role in determining (the) oversight role of MPs [...] for instance the anti-corruption agenda is our party agenda since 2005 [...] all members of the opposition adopted this stance when we joined the parliament '(opposition MP). Such strong belief in the party is exemplified as well by the rejection of the statement that 'using court injunctions, executives can easily evade serious debate about accountability issues in the parliament' (\#185). This implies that for this cluster executives cannot easily escape from being held accountable.

Furthermore, while other clusters believe this to be true, MPs in this group reject the statement that their oversight role is constrained by the fact that the speaker of the parliament uses MPs from the ruling party to pass controversial bills (\#32 -5). The MPs also rejected the statement 
that when election time approaches, controversial bills are tabled by the executive before the parliament because at such time MPs would be paying more attention to re-election (\#28 -4). However, this needs to be interpreted in the light of what was happening during the interview period: three bills were tabled in the parliament under a certificate of urgency and were forcedly passed despite strong resistance from the opposition MPs, who were banned from appearing in parliament due to alleged 'misconduct'.

Unlike MPs in the MEA cluster who scored (\#9 -5), the PC cluster feel obliged to explain how they accomplished their achievements $(\# 9+3)$ : 'These days people talk about transparency everywhere [...] to me I think it makes sense to deliver your promises to the voters, but also explain to them how you managed to deliver or failed to deliver [...] this will make you an MP of the people and prepare good grounds for re-election' (MP ruling party). This belief may be informed by the need to build a good party image, which is at the source of re-election possibilities (MPs cannot stand independently). The party caucus thus plays a crucial role in determining whether MPs will hold the executive to account $(\# 7+4)$ : 'The party caucus is a way of keeping MPs on track, to make them work together as a team to avoid divisions and factions within the party. It determines to a great extent which position MPs should adopt in the parliament' (MP ruling party).

Although PC members like MEAs show a strong allegiance to the electorate for re-election purposes (both score $\# 8+5$ ), the big difference is that they strongly believe in facts and reasoning as opposed to hearsay when they deliberate in parliament $(\# 2+5)$, and more oriented to policy issues than patronage interests $(\# 3+3)$. This view may result from the fact that most of the MPs in this cluster are young and well educated, and able to read complex policy proposals and make informed deliberations in the parliament. MPs in this group strongly believe that if they smell corruption, they would always try to go to the bottom of it $(\# 15+4)$, which is a logical consequence of rejecting the statement that debating on corruption is merely a political façade (\#14 -4). Thus the PC discourse on accountability may be summarized as: only the party can effectively hold the executive to account.

\subsubsection{Frustrated Account Holders (FAH) \\ "Yes we can but the party/political system fails us"}

This cluster is the largest one, with nine MPs. The group is balanced in gender $(5 \mathrm{M}-4 \mathrm{~F})$ and highly experienced: their age is between 50 and 58, and most MPs are in their second or third term. The group consists in equal proportions of both ruling and opposition party members.

MPs in this cluster share the allegiance to the electorate with the MEA cluster $(\# 8+5)$ and with the PC cluster $(\# 8+5)$, although more weakly $(\# 8+2)$. Contrary to MEA and PC clusters, who believe in the power of re-election and/or the (ruling) political party as mechanism of holding the executive to account, MPs in this group believe that they should do so as parliamentarians with their own parliamentary resources, i.e. going through the Controller and Auditor General (CAG) and Public Accounts Committee (PAC). This is exemplified by strongly agreeing to hold the executive to account when implicated by CAG reports $(\# 35+5)$ and seeing the PAC as the most active and capable parliamentary committee in holding the executive to account $(\# 36+4)$.

They also believe that there are too many party-political and political-social constraints on holding the executive to account in practice, hence their frustration. The ruling party MPs in 
FAH are frustrated by both the party constraints and the political system (e.g. the constitution) (\#3 -2), while the opposition MPs in FAH are frustrated by parliamentary practices that favours the ruling party and the political system: 'Party factions have weakened and paralyze my party. There are a dozen of camps with different interests in the party. This is not healthy for effective oversight role of an MP' (MP ruling party). 'Party factions are a result of poor leadership and power mongering. The factions are formed during the internal nomination processes and last afterwards $[\ldots]$ neither the chairman nor senior party leaders have moral authority to stop this $[\ldots]$ in the end it cost the party dearly in the parliament and in the constituencies' (MP ruling party).

Showing deep commitment to accountability as such, and despite the frustration with party factions and corruption, the FAH MPs strongly believe that if they smell corruption they will always try to go to the bottom of it $(\# 15+5)$. Conversely, they reject the statement that debating on corruption is merely a political façade (\#14 -3). But at the same time they believe that powerful interests bribe MPs to pass budgets for given ministries $(\# 40+3)$ : 'Everyone understands the magnitude of corruption in this country, including we MPs, but let us be honest why corruption does not end?, it is because everyone benefits. I may look very genuine in fighting corruption in the parliament but who knows I have been paid to shout about it [...] I think it is difficult to judge' (Opposition MP).

The ruling party and opposition MPs in this group believe that the constitution and its interpretation give too much power to the president and the executive over the parliament (\#11+4): 'The appointment powers over members of parliament that the president has, weaken parliament oversight over the executive [...] the President is also the chairman of the party in power - this gives him a lot of powers to control MPs through the party' (MP ruling party). MPs in this group also believe that Tanzanian society at large is not socialized to give account on one's actions/inactions and neither is the executive $(\# 21+3)$. Scheduling tricks used by the Speaker $(\# 28+3 ; \# 32+4)$ add to their frustration: 'The Speaker of the parliament should be more neutral. She is favouring much the CCM MPs and executive. The era of a single party parliament is gone. We are in a multiparty parliament' (Opposition MP).

However, MPs in this group do not believe that their oversight role is constrained by the fact that fellow MPs from the same political party are also ministers (\#38 -4); and, somewhat surprisingly given their stress on the appointment powers of the president, strongly disagree that appointed MPs cannot hold the executive to account (\#39-5). Demonstrating a commitment to accountability per se, they do not think that being loyal to the party also means than they should refrain from holding the executive to account (\#5 -3); nor that they cannot work with other political parties to hold the executive to account because it might put their party loyalty in question (\#6-2). Likewise, they strongly disagree that their informal relationships weaken the party (\#10 -5). Summarizing this cluster's stance on accountability: As parliamentarians we are committed to hold the executive to account with our own parliamentarian resources, but as yet there are too many (party) political constraints to achieving this in practice.

\subsubsection{Pragmatic Account Holders (PAH)}

\section{"We can only hold the executives to account in collaboration with CSOs"}

This cluster has four MPs. It is dominated by older males (age 45-58) $(3 \mathrm{M}-1 \mathrm{~F})$ of the ruling party (3) in their second or third term (3). 
As pragmatic politicians, this group of MPs believe that holding the executive to account is very important but contextual; they can sometimes hold the executive to account with the help of journalists (and 'society') and sometimes they cannot because of inherent impediments. Contrary to MPs in the FAH cluster, who rely on parliamentary resources alone, this group therefore believes in the power of external actors to hold the executive to account $(\# 23+5)$.

One MP narrated how Twaweza and Haki Elimu (active NGO's working in the education, water and health sectors) helped MPs with data to question the government: 'There are very few mainstream investigative papers which are doing a wonderful job [...] these newspapers help me a lot because they bring up serious policy issues which assist me in deliberating in the parliament' (MP ruling party). However, media support is not sufficiently effective yet. On this account PAH MPs believe that powerful interest bribe MPs to pass budgets for given ministries $(\# 40+5)$ : 'The budget season is a great opportunity for some money loving MPs [...] I cannot deny that influential companies and business people usually come to parliamentary grounds to lobby MPs [...] there are also officials within ministries who lobby MPs through brown envelops' (MP ruling party). These MPs also rejected the statement that although the media pay a lot of attention to corruption, their politically biased reporting never influences MPs own political judgment in accountability issues (\#17-3): 'There are very few MPs who pay attention to media bias in reporting corruption [...] usually MPs would consider the media as a very important source of information [...] it has always been like that' (MP ruling party).

Furthermore, MPs in this group strongly believe that the culture of the executive to protect each other during "scandals" in the parliament constrains their own ability to demand accountability from the executive $(\# 26+4)$. They agree that some of the parliamentary rules and procedures hinder their ability as an MP to hold the executive to account e.g. the majority decides $(\# 41+3)$. Interestingly, all the four clusters reject the statement that MPs oversight role is constrained by the fact that fellow MPs from the same political party are also ministers (MEA \#38 -3; PC \#38 -2; FAH \#38 -4; PAH \#38-5). However, the strongest rejection comes from PAH opposition MPs; MPs from the opposition have never been appointed to a ministerial post.

The PAH MPs also feel accountable to the electorate. They would threaten the executives with tough oversight only as a political leverage to get goods for the electorate and wealth for themselves $(\# 16+3)$. Implicitly, this may also mean that they favour patronage over policy issues although the relevant statement is weakly supported $(\# 3+1)$. Yet, they reject the statement that it is logical to pretend to hold the executive to account during election times because of being worried about re-election (\#12 -3): 'If this is true then there will be very few MP who do that and they are hypocritical; if an MP is worried about re-election, it doesn't make sense to be active when election times approaches [...] voters are not stupid, they know who fake it and who is deeply concerned with their problems' (Opposition MP). The PAH MPs also somewhat disagree with the idea of holding the executive to account via the party (\#1 -2). Summarizing this cluster's views on accountability: as pragmatic politicians, MPs can sometimes hold the executive to account for achieving the electorate's preferences with the help of journalists (and 'society').

\subsection{Discussion}

There are four clearly identifiable discourses on accountability issues among Tanzanian MPs. The chief division is found between, on the one hand, MPs who believe that the political party's parliamentary representatives are the only ones who can effectively hold the executive in check, 
meanwhile serving the electorate (labelled PC for 'partycrats'), and, on the other hand, those who were never convinced of this or have given up this belief, and instead rely on their own constituency as their only political power base and issue compass in exacting accountability from the executive, labelled 'my electorate's advocates' (MEA). This tension is inherent in the Westminster model of first-past-the-post District representatives, who always have to balance party interests (imposed though the 'party caucus') and their electorate's demands.

Interestingly, both PC and MEA believe that theirs is the best way to responsiveness, i.e. to serve the electorate in a broader sense of the word. Although electoral districts in Tanzania may have some tribal or ethnic overrepresentation, even the MEA's speak about their electorates' needs and demands not in terms of private or club goods, but in terms of generic public goods and services that a state, through good governance, should supply its citizens with. Priorities may differ per constituency - some districts need more clean water and better health services, and others improved roads and better prices for their products - but constituencies' needs are not claimed by MEAs in terms of tribal or ethnic demands. In that sense, their accountability discourse is 'modern'. However, the PC discourse also stresses other elements of 'modern' politics such as facts, evidence and debate, whereas the MEA-discourse actually disparages the importance of these elements. MEA-discourse MPs, in spite of the apparent modernity of their substantive claim, actually stand in the traditions of 'the economy of affection' (Hyden 2013) and the 'politics of the belly' (Bayart 2009). This becomes particularly clear in their beliefs about answerability. Whereas PC MPs feel they should tell the electorate where and how they acquired the resources for service delivery, the MEA MPs absolve themselves of this obligation, invoking traditional family rules and habits.

The other two discourses, MPs as frustrated (FAH) or pragmatic account holders (PAH), appear to be derived from PC- and MEA-discourses. Both FAH- and PAH-discourses stress the role of parliamentarians as overseers of the executive, and they wish to see this oversight role strengthened. FAH-discourse stress systemic constraints on controllability, i.e. efforts by parliament proper to hold the executive accountable by means of its own resources and skills. The constitution, the party caucus, the speaker of the house, the legal system, educational level of some MPs, etcetera - they all impede good-willing parliamentarians to live up to their own and others' expectations in practice. Those who use a PAH-discourse appear to have learnt from these frustrations and acknowledge that parliamentarians need to collaborate with civil societyjournalists and NGOs particularly - if they want any serious impact on executive political and administrative conduct. They acknowledge that this is impossible across the board, and seem resigned to the idea that only careful selection of issues may bring occasional successes.

Somewhat surprisingly, few of the MPs' characteristics (appointed-special/elected seats, urbanrural constituency, mainland-Zanzibar, opposition-ruling party, level of education, age, gender) has an effect on membership of any of these four groups of MPs. Only age and seniority as MP were found to make a difference. Only younger and less experienced MPs are PC: if you are young but more senior, you are more likely to be MEA; and the relatively older and more experienced MPs tend to become either FAH or PAH. It looks as if MPs are recruited along party lines and are expected to follow the party line, only to learn from experience that other political actors and factors are at play in holding the executive to account and best serving one's constituency. For inexperienced MPs to be a PC may simply mean a good start to their future political career. Unlike in Ghana (Hyden 2010: 6), in Tanzania there are no MPs who have a diaspora background. Young MPs are either groomed within their respective parties or come from a strong business and educational background. There are also cases of young MPs who 
come from political dynasties, but they are mostly appointed in special seats and do not need much party support.

Although Q-method strictly speaking does not allow for generalization beyond the Q-sample, these findings invite the hypothesis that the era of strong single party rule by CCM (or, in future, an alternative opposition party) is drawing to a close. Three of the four identifiable discourses are clearly 'anti-party', although for different reasons: one's own electorate as overriding reference group and power base for accountability (MEA); and more frustrated (FAH) or pragmatic account holders (PAH) looking to a strictly parliamentarian resource base for exacting accountability (FAH), or seeking strategic collaboration with civil society actors $(\mathrm{PAH})$

Hyden's reflection on MPs' accountability practices illuminates my findings (Hyden 2010: 12). It would seem that MEA-discourse MPs keep choosing the populist, overtly clientelistic route of patronage for their own constituency. PC MPs take one step more toward political modernity in allowing for policy considerations, fact-based rational debate, and some networking, albeit within the confines of one political party and its strategies. On the basis of his research, Hyden postulated that party cultures would be important determinants for enhanced political accountability. His typology of party cultures uses two parameters, deliberation and loyalty (Hyden 2010: 17-19). 'Deliberation' is the extent to which a party culture encourages openminded and business-like deliberation to process political issues. 'Loyalty' expresses the extent to which a political party demands loyalty from its MPs, i.e. the degree to which they are obliged to follow party instructions in parliamentary voting and other important party activities. Using my data (with the standardized factor scores on Q-statements as rough 'proxies' for aspects of 'deliberation' and 'loyalty), I intuitively and qualitatively position the four Tanzanian MPs' accountability discourses in the Hyden typology (Figure 3).

\section{Figure 11: Typology of accountability discourses (after Hyden 2010)}

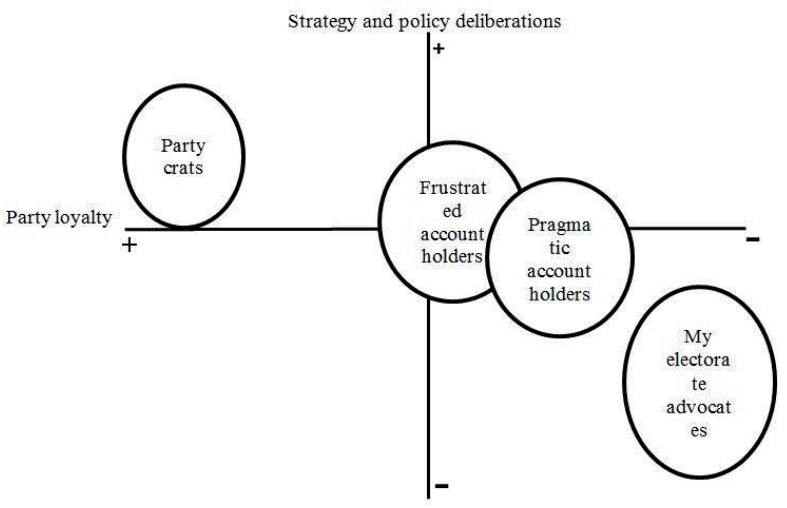

As is obvious from the previous discussion, MEA and PC-discourses have opposite scores for the deliberation and loyalty dimensions and therefore end up in opposite quadrants of the Hyden typology. Frustrated and pragmatic account holders score more or less in the middle of the 
loyalty and deliberation dimensions, and thus have a considerable overlap, but are both closer to MEA than to PC; this is supported by the score in the inter-correlation matrix. In practice this would mean that we would see MPs of FAH- and PAH-discourses side more frequently with MEA-discourse MPs.

It would appear, then, that there is more 'system in the madness' than suggested by Kelsall (2008), who maintains that there is an inscrutable 'interplay of different and often conflicting social currents, giving rise to complex and sometimes self-contradictory subjectivities, all of which make concerted action in any particular direction difficult to achieve.' In Tanzania the key to government control is, after all, the fact that PC MPs and the politically nominated members of the executive belong to the same party. This makes the following political control strategy a likely possibility (De Mesquita and Smith 2012) and one that has in fact been reported (Venugopal and Yilmaz 2010; Reith 2011; Matenge 2012). The executive controls administrative and bureaucratic service delivery to citizens through vertical accountability lines between ministries and other levels of government. So does the ruling political party, CCM.

By withholding some services, or by just-in-time service delivery in election time, the executive may influence the probability of re-election of MPs in their districts. After all, MPs are held to account by their own constituencies on the basis of their skills and ability to make the executive deliver the right type of services in the appropriate amounts. This elicits collaboration between PC-minded MPs and the executive, but MEA-minded MPs are vulnerable to such a political strategy. What Guillan-Montero (2014) has demonstrated quite convincingly for Argentina is manifest in Tanzanian parliamentarian politics as well: if necessary, MEA- and PAH MPs will 'threaten the executives with tough oversight only as political leverage to get goods for my electorate and wealth for myself' (statement \#16). Another method of collusion would be blocvoting, where District Commissioners and other senior administrators or local politicians pledge to ensure the voting support of their constituents to an MP, on condition s/he delivers what they want.

\subsection{Conclusion}

The various discourses on accountability among Tanzanian MPs enable the executive to rule in semi-autocratic ways. The weak mobilization capacity of other political players - NGOs, faithbased organizations, community-based associations, and the like - and the possibilities of choosing private solutions for public problems through bribes and other modes of corruption, political parties, for the time being, will hold the key in exacting more accountability of the executive to the preferences and demands of Tanzanian citizens. However, even if opposition parties would obtain a parliamentary majority, the accountability culture that emerges from this Q-method investigation of discourses held by Tanzanian MPs stands in the way of achieving greater democratic accountability.

The MP discourses on accountability did not emerge overnight. They reflect culture, values, traditions and ideas about morality and power rooted in the pre-colonial fabric of the society. Thus, parliamentary accountability in Tanzania is arguably a socially embedded practice interwoven with the fabric of society/government relations. The MPs' discourses indicate how the MPs view their own identity, mark them out individually, and impose a law of truth on them in their everyday lives as Members of Parliament. For instance, MPs, from both the ruling party and opposition believe that the electorate comes first, and is their first family. Thus, providing services to the electorate, including water will guarantee them re-election. However, the 
electorate equates the office of an MP to a family institution, which brings an obligation to MPs to assume the responsibility of a father in a family.

This doubles the MPs official responsibilities to provide services to the electorate to include informal ones, i.e. finance burial services, paying for school fees and, meeting health expenses for the less fortunate citizens in the constituencies, etcetera. These informal responsibilities induce MPs to engage in strategies of extraversion with the executive to obtain resources to serve their electorate. As a result, MPs find themselves in a dilemma: holding the executive to account as required by their formal oversight mandates, and seeking resources from the executives to take care of their respective constituencies. The latter guarantees them re-election, which makes it a preferred choice. This scenario resembles the role played by chiefs during the pre-colonial and later on the colonial periods. In the pre-colonial period, chiefs had to strike a balance between the interest of the traders and that of their communities. In the colonial period, they had to balance the interests of the coloniser against that of their societies. In both cases, they engaged in strategies of extraversion in order to maintain their power.

Thus, the attempt to shape with some degree of deliberation the parliamentary accountability practices, as advocated by international donors, according to particular sets of R-M-Ts, including those enshrined in the New Public Management, without grasping the governmentalities that drive parliamentary accountability in Tanzania, will be of limited impact. Table 14 summarises the R-M-Ts inherent in the accountability types of MPs and those of NMP. 
Table 14: Accountability types of MPs compared to NPM-type accountability

\begin{tabular}{|c|c|c|}
\hline 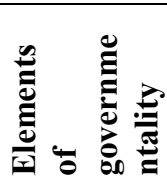 & Accountability types of MPs & NPM-type accountability \\
\hline $\mathbf{R}$ & $\begin{array}{l}\text { Thinking about accountability is } \\
\text { based on the fusion between good } \\
\text { governance reforms and } \\
\text { traditional governance practices. } \\
\text { The former is inspired by post- } \\
\text { colonial R-M-Ts while the latter } \\
\text { is inspired by the pre-colonial and } \\
\text { colonial ones. } \\
\text { The key to political control is } \\
\text { vertical accountability through } \\
\text { the ruling party and ministries }\end{array}$ & $\begin{array}{l}\text { Thinking about accountability is based on } \\
\text { good governance reforms inspired by the } \\
\text { Principal-Agent theory and Collective- } \\
\text { Action theories } \\
\text { The key to political control is through } \\
\text { vertical, and horizontal accountability }\end{array}$ \\
\hline $\mathbf{M}$ & $\begin{array}{l}\text { MP office fused with traditional } \\
\text { notions of family, e.g. an MP is } \\
\text { regarded as a farther who has to } \\
\text { provide goods such as water, } \\
\text { health care, education to his } \\
\text { children - the electorate } \\
\text { Limited oversight for } \\
\text { extraversion strategies } \\
\text { Patron-client politics } \\
\text { Reciprocity obligations }\end{array}$ & $\begin{array}{l}\text { Separation of personal and official } \\
\text { obligations of an MP } \\
\begin{array}{l}\text { Oversight for country's } \\
\text { development }\end{array} \\
\begin{array}{l}\text { Critical of patron-client politics and } \\
\text { reciprocity obligations as hindering } \\
\text { formal accountability }\end{array}\end{array}$ \\
\hline $\mathbf{T}$ & $\begin{array}{l}\text { Rewards: development aid is } \\
\text { turned into opportunities for } \\
\text { extraversion strategies } \\
\text { In-time service delivery in } \\
\text { election time to influence the } \\
\text { probability of re-election of } \\
\text { MPs in their districts }\end{array}$ & $\begin{array}{l}\text { Rewards: development aid } \\
\text { Punishments: } \\
\text { Freezing } \\
\text { development aid } \\
\text { Reduce budget support }\end{array}$ \\
\hline
\end{tabular}

Meanwhile, national accountability practices have an imitative nature, particularly to local levels of governance, this leads me to examine accountability practices in a local government setting, in the next chapter. 


\section{Local government accountability practices: a case of rural water supply in Bunda District $^{27}$}

The question of accountability in local government authorities has been at the heart of most of the literature focusing on formal accountability in Tanzania. However, little is known about the relationship between different types of informal accountability and, perhaps more importantly, the multiple relationships between formal and informal accountability in local government authorities. Equally, the existing literature on local government accountability has been rather generic and has rarely focused on sector specific contexts, the water sector in particular. Notably, the academic literature on accountability in the context of rural water supply in local government authorities is scanty and patchy, and most of the literature found on this topic is grey.

In this chapter, I employ a qualitative case study design to examine accountability practices at the local government level. The research question I investigate is how public officials are held to account at the local government level? In particular I examine whether the councillors can hold the executive (public officials) at the local level to account. In particular, I investigate accountability relationships between councillors and local government executives in the context of rural water supply in Bunda District. I argue that formal accountability mechanisms which are to keep in check the actions and inaction of public officials are weak. The much stronger informal accountability mechanisms exist in a parallel world and determine for a larger part which actions are taken to improve service delivery. These informal accountability mechanisms are classified as 'competing' with formal accountability mechanisms because they structure politicians and bureaucrats incentives in ways that are incompatible with the formal service delivery mandates. In addition, I also argue that there are other forms of behaviour independent of formal and informal institutions (non-accountability influences) which affect accountability and obstruct the provision of access to rural water services, namely: loans as a predicament for oversight role of councillors; party caucus, and central-local relations. First, I provide background information about the case study.

\subsection{Bunda District: the case study}

The name 'Bunda' comes from a local language called 'Mabunda', which literally means a lion cub, according to the local people. The name emerged as a result of the proliferation of lions from the Serengeti National Park that were giving birth in areas close to human settlements. Thus, when people saw the lion cubs they called them 'Mabunda'. Over time, the name was popularized and became the official district name.

Bunda district is found in the Mara region in northern Tanzania. It is one of the six districts forming the Mara region (Figure 12).

\footnotetext{
${ }^{27}$ An earlier version of this chapter was presented as Katomero et al. (2015) at the 3rd ECPR Joint Sessions of Workshops, Workshop 19 - Intricacies of Accountability: Horizontal, Diagonal and Vertical Mechanisms to Combat Corruption, University of Warsaw, Poland, 29th March-2nd April, 2015
} 
Figure 12: Map of Tanzania indicating the study area

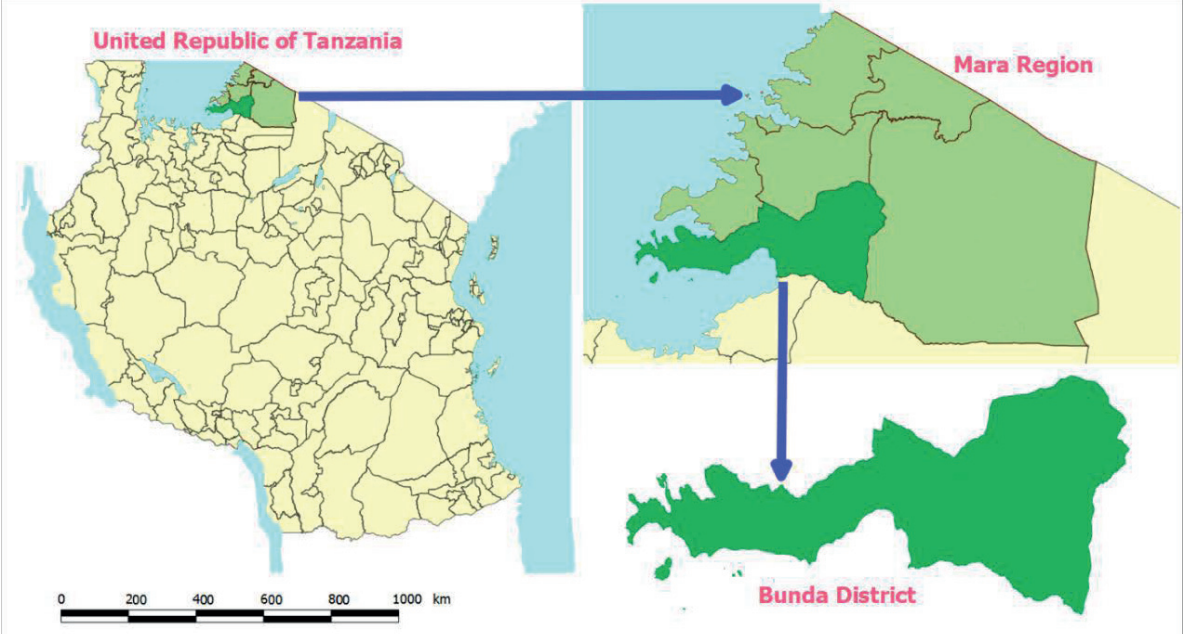

According to National Housing and Population Census of 2012, Bunda district has 335,061 people, with a growth rate of 1.8 percent (Bunda District Council and NBS, 2014).

Table 15: Population size by district in Mara Region

(Source: Bunda District Council and NBS, 2014)

\begin{tabular}{|c|c|c|c|c|c|c|c|}
\hline \multirow[t]{3}{*}{ District } & \multicolumn{3}{|c|}{2002 population census } & \multicolumn{3}{|c|}{2012 population censu } & \multirow{3}{*}{$\begin{array}{l}\begin{array}{l}\text { Growth } \\
\text { Rate \% }\end{array} \\
1988-2012\end{array}$} \\
\hline & \multicolumn{2}{|l|}{ Number } & \multirow[t]{2}{*}{ Total } & \multicolumn{2}{|c|}{ Numbe } & \multirow[t]{2}{*}{ Total } & \\
\hline & $\mathrm{M}$ & $\mathrm{F}$ & & \begin{tabular}{l|l}
$\mathrm{M}$ \\
\end{tabular} & $\bar{F}$ & & \\
\hline Bunda & 128,824 & 130,106 & 260,000 & 162,24 & 172,820 & 335,061 & 1.8 \\
\hline Tarime & 231,636 & 259,095 & 492,798 & 162,98 & 176,707 & 339,693 & 2.8 \\
\hline Serengeti & 83,932 & 92,677 & 176,609 & 121,39 & 128,021 & 249,420 & 3.3 \\
\hline $\begin{array}{l}\text { Musoma } \\
\text { District }\end{array}$ & 158,554 & 171,270 & 330,953 & 87,32 & 91,032 & 178,356 & 2.5 \\
\hline $\begin{array}{l}\text { Musoma } \\
\text { Municipal }\end{array}$ & 51,607 & 56,248 & 108,242 & 62,69 & 71,633 & 134,327 & 3.3 \\
\hline Rorya & - & - & - & 126,24 & 134,994 & 264,241 & - \\
\hline Butiama & - & - & - & 117,12 & 124,603 & 241,732 & 2.9 \\
\hline Total & 654,553 & 709,396 & $1,368,602$ & 840,02 & 903,810 & $1,743,830$ & \\
\hline
\end{tabular}

The main economic activities in the district include: agriculture, animal husbandry, fishing and petty trading. Agriculture, livestock keeping and fisheries contribute about $81 \%$ of the District GDP (Bunda District Council, 2008:7; Bunda District Council, 2014; Deule, 2010:10; NBS, 2008; UNDP-UNEP PEI, 2014). According to 2013 per capital income figures, per capita income of Bunda District was relatively low Tsh 145,343 (58 euro) compared to the national per capita income of Tsh 253,000 (100 euro) in the same year. This ranks Bunda among poorest districts in Tanzania (UNDP-UNEP PEI, 2014). 
Given the poor revenue base, the district is heavily dependent on financial grants and disbursements from the central government to finance development projects. About $90 \%$ of the council approved budget comes from the central government, through the Prime Minister's Office-Regional Administration and Local Government (PORALG), to finance development activities (Bunda District Council, 2014; UNDP-UNEP PEI, 2014). Although the council collects revenue fees from tax registration, bus stands, forestry products, valuation licenses, markets, fines, hired vehicles, etc., there is always an outcry from local officials relating to the funding of local development activities (UNDP-UNEP PEI, 2014).

\subsubsection{The political and administrative set up}

The administrative set-up of the district comprises 28 wards, 4 divisions, 106 villages and 572 hamlets (Bunda District Council, 2014).

Table 16: The political and administrative set up of Bunda district

(Source: Bunda District Council and NBS, 2014)

\begin{tabular}{|l|r|r|r|}
\hline Division & Number of wards & Number of Villages & Number of Hamlets \\
\hline Serengeti & 10 & 29 & 176 \\
\hline Chamriho & 7 & 28 & 150 \\
\hline Nansimo & 6 & 26 & 108 \\
\hline Kenkombyo & 5 & 23 & 138 \\
\hline Total area & 28 & 106 & 572 \\
\hline
\end{tabular}

The administrative structure of Bunda District is formed by local government officials, headed by a District Executive Director (DED), and the District Administrative Secretary (DAS). The political structure (at the senior level) is comprised of the District Commissioner (DC) and the District Chairperson as well as the councillors. The politics/administration dichotomy of the district reflects Bovens' actor-forum accountability framework where politicians (District Commissioner, District Chairperson) are account holders and the DED, DAS and heads of departments are accountors.

\subsubsection{The Political Context}

Mara region and Bunda district have a unique political history that has influenced both local and national politics for years. The political context of the district is characterized by influential political personalities who have had significant influence both on the district and national politics and policies. There is also increasing political space for opposition political parties to influence decisions in the district. Equally, a vibrant civil society and a civic-competent citizenry is gaining traction as well.

The district recorded its presence in the national political scene by producing the first President of Tanzania, Julius Nyerere, who ruled Tanzania from 1961 until 1985. One of his acknowledged and often contested development policy stances was socialism (Ujamaa) which sought to create inter-linked self-governing village communities by bringing people together in selected villages and providing them with basic social services so that they could effectively engage in production activities (Feirman, 1990; Nyerere, 1967). The policy did not register much success; that is why it failed in the 1970s.

Another prominent figure hailing from the district is the retired Judge from the German-based Hamburg Tribunal for the Law of the Sea. He worked as the Prime Minister of Tanzania from 
1985 to 1990. Various ministers have also originated from Bunda. One influential figure in this category was the Deputy Minister for Local Government who worked under the Nyerere administration. He served in various ministerial position for past twenty years. In the 2015 elections, he contested for a parliamentary seat in Bunda constituency, but was defeated by a young female opposition candidate. The senior politician is the longest serving Minister in the history of the country

These political personalities and many others hailing from the district have been a main thread of the socio-economic and political development connecting Bunda district and the national level government both in their personal and impersonal capacities. In their political careers they built networks of relationships (formal and informal) with the district using their influence and power to achieve personal and organisational goals. Thus, understanding accountability relationships in the context of rural water supply in Bunda, it is important to look at such networks.

Given a protracted history of the ruling political party dominance in the district, opposition political parties have been relatively weak despite increasing their share of seats in the village assembly. However, the increasing citizen's dissatisfaction with the quality of social services has made opposition political parties challenge the ruling party, particularly in the urban and peri-urban areas. For instance, in the 2014 local government elections, the competitive strength of the opposition increased tremendously, thus culminating in the increase in the number of seats at the village level in the district and village councils, respectively.

In the 2015 general elections the opposition managed to unseat the then incumbent Member of Parliament from the ruling party. Civil Society Organisations, particularly NGOs, are very active in educational, reproductive health and environmental sectors. The area of water is dominated by international NGOs such as the Netherlands Development Organisation (SNV). SNV has been working in the water sector in the rural areas in many districts in Tanzania, including Bunda through its Public Accountability in Tanzania (PATA) initiative. The initiative is used to address issues of public accountability that constrain the implementation of local level development initiatives (SNV unpublished paper). It involves a partnership between the Embassy of the Kingdom of the Netherlands (EKN), SNV Tanzania and the International Cooperation Agency of the Association of Netherlands Municipalities (VNG-I). The initiative sought to increase understanding of local dynamics with regard to local accountability by strengthening both the supply and demand side of accountability practices (SNV unpublished paper). The SNV represents yet another encounter between international donors and national government officials as well as local government officials through its capacity building programmes and accountability interventions frameworks, particularly the Public Accounatbility in Tanzania (PATA) initiative and the Water Point Functionality-Intervention Framework (WPF-IF). The two initiatives aimed at empowering local councillors and communities to exact accountability from local government officials.

\subsubsection{The rural water supply situation in Bunda district}

Despite major international donor and government investments, there are still many challenges with regards to rural water supply in Bunda district. Most of the rural areas are served with traditional water sources: springs, rivers, lakes, rain water, dam and traditional wells. A large proportion of the district residents depend on shallow wells (Table 17). 
Table 17: Number and type of rural water sources as of 2012

(Source: Bunda District Council and NBS, 2014)

\begin{tabular}{|c|c|c|c|c|c|c|c|c|c|c|c|c|c|c|c|c|c|}
\hline \multirow{2}{*}{ 总 } & \multicolumn{2}{|c|}{$\stackrel{\infty}{\Xi}$} & \multicolumn{2}{|c|}{ 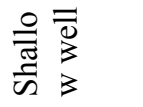 } & \multicolumn{2}{|c|}{ 离离 } & \multicolumn{2}{|c|}{$\begin{array}{c}0 \\
\stackrel{0}{0} \\
\oplus \\
0\end{array}$} & \multicolumn{2}{|c|}{ 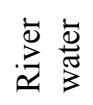 } & \multirow{2}{*}{ 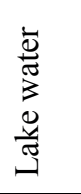 } & \multicolumn{2}{|c|}{ ఏే } & \multicolumn{2}{|c|}{ 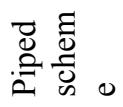 } & \multicolumn{2}{|c|}{ 壳 శ్ } \\
\hline & w & $\begin{array}{l}\mathrm{n} \\
\mathrm{w}\end{array}$ & $\mathrm{w}$ & nw & $\mathrm{w}$ & nw & $\mathrm{w}$ & nw & $\mathrm{p}$ & $\mathrm{S}$ & & $\mathrm{p}$ & $\mathrm{s}$ & $\mathrm{w}$ & nw & $\mathrm{p}$ & $\mathrm{s}$ \\
\hline Serengeti & 2 & 9 & 31 & 74 & $\begin{array}{l}1 \\
7\end{array}$ & 5 & $\begin{array}{l}3 \\
1\end{array}$ & 15 & 2 & 3 & 3 & 1 & - & 2 & 1 & 2 & - \\
\hline Chamriho & 2 & 5 & 34 & 60 & $\begin{array}{l}1 \\
5\end{array}$ & - & $\begin{array}{l}8 \\
6\end{array}$ & 11 & - & 4 & - & 3 & - & 2 & 1 & - & - \\
\hline Nansimo & 2 & - & 21 & 38 & 2 & 2 & 6 & 2 & - & 6 & 6 & 1 & - & 2 & - & - & - \\
\hline Kenkombyo & 3 & - & 11 & 42 & $\begin{array}{l}1 \\
8 \\
\end{array}$ & 1 & 5 & 2 & - & 1 & 1 & - & 3 & 2 & - & - & - \\
\hline Total & 9 & $\begin{array}{l}1 \\
4\end{array}$ & 97 & $\begin{array}{r}21 \\
4\end{array}$ & $\begin{array}{l}5 \\
2\end{array}$ & 8 & $\begin{array}{l}1 \\
2 \\
8\end{array}$ & 30 & 2 & 14 & 10 & 6 & 3 & 8 & 2 & 2 & - \\
\hline
\end{tabular}

There are 311 shallow wells in Bunda out which 97 are currently in use and 214 are not (Bunda District Council and NBS, 2014). The modern water sources such as piped/tapped water, improved wells, and bore holes are either under construction, not working properly, notfunctioning or vandalized (ibid).

In the rural water schemes, hand pump remains the main source of water in the rural areas. However, out of 452 hand pumps available in the rural areas, only $200(44.2 \%)$ hand pumps are working (Bunda District Council and NBS, 2014).

Table 18: Number and type of technology used in rural water schemes as of 2012 (Source: Bunda District Council and NBS, 2014)

\begin{tabular}{|c|c|c|c|c|c|c|c|c|c|c|c|c|}
\hline \multirow[t]{3}{*}{ Division } & \multicolumn{10}{|c|}{ Type of Technology } & \multirow{2}{*}{\multicolumn{2}{|c|}{ Total }} \\
\hline & \multicolumn{2}{|c|}{ Wind mill } & \multicolumn{2}{|c|}{$\begin{array}{l}\text { Electricity } \\
\text { pump }\end{array}$} & \multicolumn{2}{|c|}{$\begin{array}{l}\text { Diesel } \\
\text { pump }\end{array}$} & \multicolumn{2}{|c|}{$\begin{array}{l}\text { Hand } \\
\text { pump }\end{array}$} & \multicolumn{2}{|c|}{$\begin{array}{l}\text { Gravity } \\
\text { piped }\end{array}$} & & \\
\hline & $\mathrm{w}$ & nw & W & nw & $\mathrm{w}$ & nw & $\mathrm{w}$ & nw & $\mathrm{W}$ & nw & $\mathrm{W}$ & nw \\
\hline Serengeti & - & - & 1 & - & 1 & 3 & 62 & 98 & 1 & - & 65 & 101 \\
\hline Chamriho & - & - & 2 & 1 & - & - & 58 & 81 & 2 & - & 62 & 82 \\
\hline Nansimo & - & 1 & 1 & - & 1 & - & 33 & 38 & 1 & - & 36 & 39 \\
\hline Kenkombyo & 1 & - & - & - & 2 & 1 & 47 & 35 & - & - & 50 & 36 \\
\hline Total & 1 & 1 & 4 & 1 & 4 & 4 & 200 & 252 & 4 & - & 213 & 258 \\
\hline
\end{tabular}

Overall access to safe and clean water for the rural population is relatively poor. Out of 212,485 of the rural population, only $110,480(51.9 \%)$ people are served with clean and safe water. The rest (48\%) do not have access to safe and clean water in the rural areas (ibid). This fact is supported by the water policy of 2002 which puts access to reliable and clean water supply services in rural settings to 50\% (Bunda District Council and NBS, 2014). 
Table 19: Percentage of rural population served with clean water in 2012

(Source: Bunda District Council and NBS, 2014)

\begin{tabular}{|l|r|r|r|r|r|}
\hline Division & $\begin{array}{l}\text { Total rural } \\
\text { population }\end{array}$ & $\begin{array}{l}\text { Population } \\
\text { served } \\
\text { with clean } \\
\text { water }\end{array}$ & $\begin{array}{l}\text { Percent } \\
\text { population } \\
\text { served } \\
\text { with clean } \\
\text { water }\end{array}$ & $\begin{array}{l}\text { Population } \\
\text { not served } \\
\text { with clean } \\
\text { water }\end{array}$ & $\begin{array}{l}\text { Percent } \\
\text { population } \\
\text { not served } \\
\text { with clean } \\
\text { water }\end{array}$ \\
\hline Serengeti & 54,539 & 28,750 & 52,7 & 25,789 & 47.3 \\
\hline Chamriho & 61,792 & 27,506 & 44,5 & 34,289 & 55.5 \\
\hline Nansimo & 52,209 & 27,131 & 51,9 & 25,078 & 48 \\
\hline Kenkombyo & 43,945 & 27,093 & 61,7 & 16,852 & 38.3 \\
\hline Total & 212,485 & 110,480 & 51.9 & 102,005 & 48 \\
\hline
\end{tabular}

Given the above non-satisfactory problematic situation of water delivery situation, domestic and international efforts have been underway to rectify the situation. These efforts date back from the independence period to date.

\section{Policy/Planning history to address the non-satisfactory situation of rural water supply}

Domestic efforts to rectify the non-satisfactory rural water supply situation can be traced from the 1960s after Tanzania attained its independence. Local government authorities, including Bunda district had inherited a colonial water infrastructure which was designed to serve households, particularly in urban settings. There was no infrastructure to support water supply in rural areas. Recognizing this shortcoming, the government used the inherited colonial infrastructure set-up in urban settings to expand water supply services to remote villages. In the 1970s, the newly formed political party CCM, took interest in water policies, focusing on improving the rural water supply sector. However, there were no regular party reviews of progress in the sector. For instance, the year 1981 passed in silence without reviewing achievements. Instead, individual members of the party and parliament tried to secure new rural water supplies for their own constituencies (Boesen et al., 1986). Their interests for water projects for their constituencies did not go beyond the struggle for funds for specific water projects (ibid).

However, the efforts to expand water infrastructure to the rural population were not successful in the 1970s. Several factors accounted for the non-satisfactory situation. In the 1970s Tanzania was hit by the economic crisis caused by the Kagera-Uganda war (1978-79), the oil crisis of $1980 \mathrm{~s}$, and the poor micro and macro-economic performance as a result of the Structural Adjustment Programmes (SAP's) advocated by the WB and IMF. The economic crisis contributed to the deterioration of social service delivery, including water in urban and rural areas of Tanzania. As a result, there was a lack of high-level interest in rural water supply because of huge investments in financial and technological terms in the rural water supply sector, which the government could not bear (Boesen et al., 1986).

Thus, given the above situation, the government requested technical and financial assistance from international donors. Notably, the international donor involvement in the rural water sector was a result of a number of factors. First, as noted above, the withering high-level interest in rural water supply combined with the need for external financial support and technical assistance placed donors in a key position in the rural water supply sector. For instance, from 1971, almost one million people had to be given access to an improved water supply each year 
(Boesen et al., 1986). This meant an immediate increase in annual implementation capacity. The ministry did not have this capacity in terms of funds, materials, technologies and man power (ibid)

Meanwhile, the international donor interest in supporting basic needs fitted well with the Tanzania's appeal to improve the social services delivery situation, particularly water. Rural water supply in particular appeared quite suitable. This is because investments in the rural water supply sector required substantial inputs of imported materials which could be bought in the donor's home countries (Boesen et al., 1986). Equally, the investments were capable of absorbing substantial amounts of donor funds as well as necessitating substantial technical assistance which the donor could supply and through which the aid money could be controlled (ibid). In general rural development aid had high priority at all levels in the recipient society, this made it appear non-controversial as both the government and international donors regarded the problems in the rural water as technical, hence the need for technical solutions to address them (Boesen et al., 1986).

The first phase of international donor involvement in the rural sector was during the 1970s. Various international donor agencies supported the rural water sector in that period. The main donors in this period included: the Netherlands International Development Agency (IDGIS), the Norwegian Agency for Development Cooperation (NORAD) and the Denmark International Development Agency (DANIDA). These donor agencies supported rural water supply projects in Tanzania focusing on technical aspects of the problems that faced the rural water sector (Boesen et al., 1986). However, the main focus was on project instead of programme aid. The policy shift from programme to project aid was made to attain a better control over funds. By 1978/79 a total of 46 projects were financed by 16 different donors (Boesen et al., 1986). Another way to increase donor control was to give project aid to specific regions only. The ministry encouraged the new arrangement of individual regions where donors could get actively involved in both the planning and implementation of rural water supply (ibid).

Sweden has been the major supporter of the rural water programme since 1960s until the end of 1970s when it gradually shifted to project aid (Boesen et al., 1986). The Swedish Government through its Swedish International Development Cooperation Agency (SIDA) provided technical and financial support through the Health Sanitation and Water project (HESAWA) project to improve rural water supply in local government authorities in the lake zone.

The HESAWA programme operated in the lake zone and covered 17 districts in three regions: five in Kagera, eight in Mwanza, and four in Mara region and it served 3,248,000 rural inhabitants (Rautanen et al., 2006:7). Bunda was one of the districts in Mara region included in the programme. The overall aim of the HESAWA programme was to improve the welfare of the rural population through improved health education, environmental sanitation, drinking water supply, community participation, and capability and capacity building at the village and district levels (ibid:26). The programme covered about 61 per cent of the total population and was implemented in four phases from 1985 to 2002 (ibid: 7).

The first phase (1985-1991) was 'experimental' and focused on the rehabilitation and construction of large gravity schemes, solar power and shallow wells as well as high tech welldrilling and rainwater harvesting (Rautanen et al., 2006:25). It covered six districts and was characterized by heavy external donor consultant input with little local participation or local 
financing. The second phase (1991-1994) was referred to as the phase of 'decentralization to district authorities' and used more Tanzanian human resources and fewer expatriate consultants (ibid: 25). The district authorities were more involved in the activities and the expatriate and Tanzanian consultants' role became more advisory (ibid: 25). Here, the district authorities were more involved, and the expatriate and Tanzanian consultant's roles shifted and became more that of advisory (Rautanen et al., 2006:25). The third phase (1994-1998) was termed a 'full decentralization' phase and focused on the choice of appropriate and affordable technology, including high tech well-drilling (ibid: 25). It was during this phase that the concept of Water User Groups (WUGs) was introduced. The fourth phase (1998-2002) was called 'consolidation and sustainability' phase (ibid: 25). It was during this phase where the concept of Water User Groups (WUGs) was introduced. The fourth phase (1998-2002) was labelled 'consolidation and sustainability' (Rautanen et al., 2006:7). In this phase, the principles of affordability, sustainability, replicability, credibility and cost efficiency were emphasized (Rautanen et al., 2006:25).

Overall, HESAWA was basically a construction programme with heavy inputs in physical infrastructure rather than participatory infrastructure focused largely on the provision of water and operational efficiency through an input-output oriented approach, directed at procurement, storage and distribution of equipment and supplies (ibid). Other donors who supported the HESAWA programme in the lake zone include: the Netherlands, Norway, Australia and Finland (ibid: 24).

However, the HESAWA project, including other donor-funded projects in the rural water sector did not become sustainable when the donor funding came to an end. Several reasons accounted for their failure. First, the capacity of local institutions to take over when the donor withdrew was not increased. Instead, they were passed by project units which frequently attracted the best field staff from the ministry thereby weakening and fragmenting it (Boesen et al., 1986). Secondly, few attempts were made at coordinating the donor's activities in the rural water sector because both government officials and donors were in basic agreement on the paramountcy of constructing new schemes (ibid). Thus, in the absence of coordination a cacophony of donor financed plans, technologies, and policies emerged (Boesen et al., 1986). Plans that differed in scope, methodology and detail were worked out in isolation from the Tanzanian institutions (ibid).

Technologies were often incompatible because each donor tended to import own materials, fittings and pump types (Boesen et al., 1986). For example the possibility to linking the rural water sector development to industrial development through the local production of simple hand pumps was never entirely pursued (ibid). Thus, when poverty struck in rural settings, villagers vandalised the water infrastructure, including pipes and sell them for survival (Field work, 2014). Similarly, the policies of the donors were not only different from, but sometimes contradictory to official Tanzanian policies (Boesen et al., 1986; Lynge, 2009). For instance, the World Bank demanded advance user payment for hand pumps in the lake zone projects, including Mwanza region while villagers in Finish-donor funded projects were payed to excavate trenches (Boesen et al., 1986). Thus, the World Bank abolished the principle of "free" water supplies while the Finns abolished the principle of self-help, both of them key aspects of Tanzanian rural development policies, including the rural water supply in Bunda district (ibid). Despite protracted donor-funded projects, in the rural the water sector, in the first phase of the international donor involvement, the rural water sector did not improve. 
The second phase of international donor involvement in the sector began from 2000 onwards. From that period, international donors have been extending their technical and financial support to revive the rural water supply situation in local authorities, including Bunda district. For instance, in 2005 the Japan International Cooperation Agency (JICA) embarked on a project of building deep wells in the rural areas of Tanzania. Bunda district was a beneficiary of these water projects. Equally, the National Rural Water Supply and Sanitation Programme (NRWSSP) was formulated for the period 2006-2025 to improve rural water supply and sanitation services in rural settings (African Development Bank, 2010: 2). The programme was specifically formulated to meet the MDGs targets on water and beyond. It's main funders include: the World Bank (WB), European Union (EU), French Development Agency (AFD), the German Government-owned Development Bank-Kreditanstalt Fur Wiederaufbau (KfW), German Technical Cooperation Agency (GTZ), Millennium Challenge Corporation (MCC), Africa Development Bank (ADB), Japan International Cooperation Agency (JICA), United Kingdom Department for International Development (DFID), Water Aid, The Netherlands Development Organisation (SNV) as well as the Netherlands Government (ibid: 2).

In the recent past, the World Bank (WB) launched and financed 10 villages' water projects in local government authorities in Tanzania. Some of these water projects are being constructed in Bunda district. As part of efforts to improve accountability in the rural water sector, the SNV introduced the Water Point Functionality Intervention Framework (WP-FIF) designed to empower councillors to hold the local executives to account. The African Development Bank supported the rehabilitation and construction of health facilities in Bunda district. Over all, most of the new water projects in the rural settings are being financed by the World Bank and other international donors (Figure 13).

Figure 13: World Bank and other international donor's in rural water projects (Source: Fieldwork, 2013-2014)

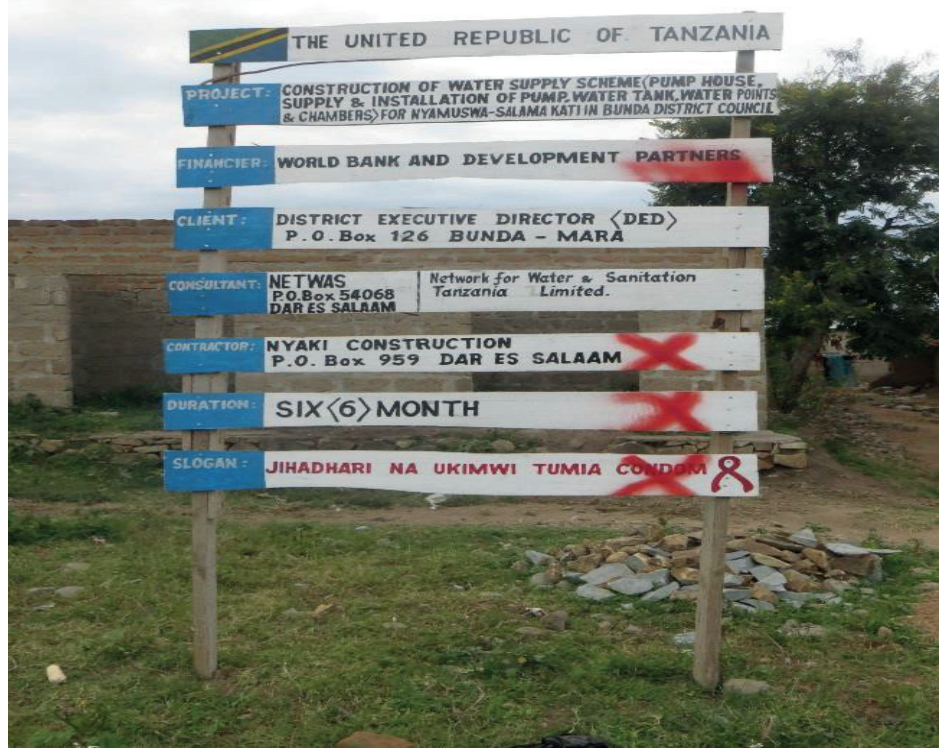


The resurgence of international donors in supporting the rural water sector came with governmentalities informed by policy beliefs focused on a participatory models of managing the rural water sector. For instance, instead of advocating for technical solutions to address the rural water problems, donors are increasingly favouring participatory governance approaches to managing the rural water sector. In its main funding document, the Water Sector Development Programme (WSDP), international donors and national government officials explain the reasons behind the adoption of a new model of managing water supply in the rural areas called Community Water Supply Organisation (COWSO) that:

\begin{abstract}
"For a long time, the government has been the owner and operator of rural water supply systems. This has led to lack of commitment by communities to sustain their facilities. It has also led to overlap of roles and inadequate coordination. Many existing water supply systems are unable to meet the demands of a growing population. This has led to the prevalence of water borne diseases and loss of productive time that is used to search for, collect and transport water. Projects and programmes have typically been implemented by a variety of government agencies and non-governmental organizations using inconsistent approaches which have not always included the participation and system ownership by the beneficiaries. Overlaps of responsibilities and interventions have also meant inefficient application of resources across the sub-sector..." (WSDP, 2006: 2)
\end{abstract}

Thus, it was imperative, in the thinking of the international donors and national public officials to propose a new system of managing rural water supply called COWSO, which would help address the challenges facing the rural water sector.

Meanwhile, in a quest to make local government authorities autonomous in executing their service delivery mandates, the government (through the support of international donors) reformed the water sector by implementing decentralisation by devolution reforms. The reforms aimed at giving power and authority to local governments to enable them to make decisions that affect the wellbeing of their localities. This also meant that executive officials were to be accountable to local councillors for their actions and inactions. The political component of decentralisation by devolution gives power and authority to local councillors to hold the executive officials to account. The administrative component of decentralisation by devolution gives power and authority to executive officials to implement their duties without interference from the central government. However there is existing gaps with regards to what the rural water situation ought to be in the thinking of international donors and national government officials and what the rural water situation actually is. I present the findings next.

\title{
6.2 Findings
}

The data presented in this section were analysed qualitatively. The specific details on the method used to collected the data, including how the data were analysed is presented in chapter one.

I found that informal accountability mechanisms compete with formal accountability mechanisms and structure the local government officials' behaviour in a manner that is incompatible with the formal accountability mechanisms. These include: kinship bonds, clientelism, rent-seeking and political interference. In addition to these findings, I also describe 
the influence of transnational policies and governmentalities on local water governance using the case of the Big Results Now (BRN) programme in section 6.3. First, however, I present the findings on the present formal institutions that should structure the local government officials' behaviour.

\subsubsection{Formal Institutions that should structure public official's behaviours}

Bunda district officials are required to execute their formal mandates as stipulated in the Local Government Act of 1982. The officials are mandated to ensure effective and equitable delivery of qualitative and quantitative services, including water to the people (Kuusi, 2009). Equally, section 111 and 118 of the Local Government District Authorities Act No. 7 of 1982 prescribe that the local government authorities are responsible for the provision of basic services, including local water supply (ibid).

In Bunda district, the responsibility of managing rural water supply is entrusted with the senior district officials, including the District Water Engineer (DWE), District Executive Director (DED), and the District Water and Sanitation Team (DWST). The DWST is formed by heads of department's (senior officers in LGA departments responsible for water and sanitation) who are appointed by the DED by an official letter describing the area of responsibility for each member. It has the responsibility of coordinating development activities related to water and sanitation. The objective is to create a platform where senior professionals from different departments work together in a team to jointly plan, implement, and monitor activities related to water and sanitation. The team meets on monthly and quarterly basis and report to the Council Management Team.

However, in Bunda district, the DWST does not have power to influence its recommendations for implementation for it is not a legal structure. Most of the members are pre-occupied with their official tasks in their respective departments rather than those of the team. Heads of departments are transferred to other district council quit often preventing cohesion and formality of the team. Consequently, the regular meeting that are supposed to be held on monthly and quarterly basis are not being held and the recommendations given by the team to Council Management Team are rarely followed.

These officials are supposed to be formally accountable to councillors in the district and not to the central government. In particular, they are formally required to provide information related to income and expenditure in regard to water projects in the district, coverage and accessibility of water services, construction of water projects including, renovation of old and construction of new water projects as well as functional and non-functional water points (figure 14). Other formal forums of accountability where councillors and administrative officials are formally supposed to deliberate and render accounts include: project site meetings, ward development committees meetings and committees meeting. In these forums councillors are formally required to perform oversight roles over administrative officials. On the other hand, administrative officials are required to provide information of their actions and inactions regarding the rural water supply services during council proceedings (Fieldwork 2013-2014). 
Figure 14: Formal accountability requirements in rural water supply in Bunda

(Source: Inspired by Bovens, 2007 and Willems, 2010)

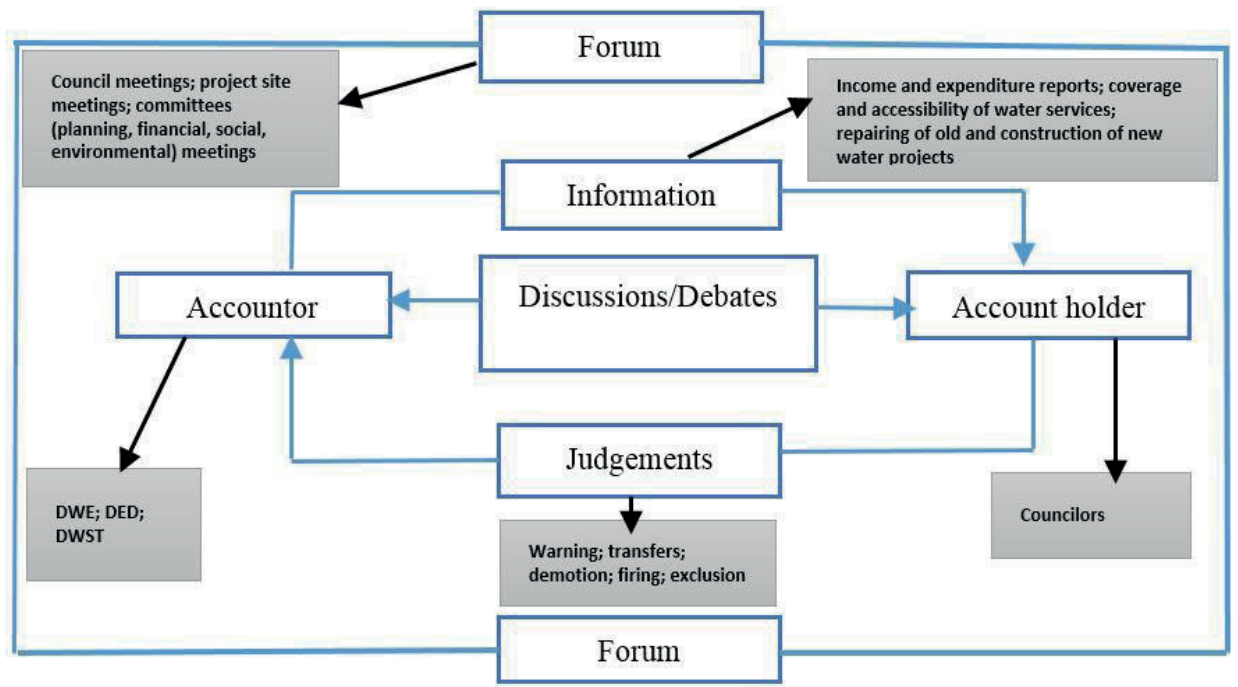

The same practice happens in village councils - but with a focus on village affairs. In both contexts, the account holders are supposed to be the councillors and the accountor are supposed to be the DWE, DED, and DWST (figure 14).

\subsubsection{Competition between formal and informal accountability mechanism}

I find several types of informal accountability mechanisms in Bunda, competing with formal accountability mechanisms with conflicting goals. The informal accountability mechanisms structure local politicians and bureaucrat's incentives in ways that are incompatible with the formal service delivery mandates. In particular, the following informal institutions came to light: Kinship bonds, patronage exchanges, rent-seeking and political interference.

\section{Kinship bonds}

A kinship bond is an informal institution originating from a web of social relationships binding together people who are part of the bond. The bond may come from family roots or friendships and may extend to other networks with which the actors have social, economic and political relationships. Goran Hyden's notion of the economy of affection is relevant here. "The economy of affection blends economic and social rationality where individuals become rational in the sense of pursuing strategies that are embedded in local social contexts" (Hyden, 2006:3). In a similar vein, a network of support, communication and interaction among structurally defined groups connected by blood, kin, community or other affiliations, for example religion, are part of this (ibid.:3). The councillors and bureaucrats in Bunda have close ties with the family members and friends working in the district and the rural water supply department in the MoW. This network extends to consultancy firms and companies that are involved in the construction of water projects in the district. This network extends to consultancy firms and companies that are involved in the "construction" of water projects in the district. The networks are in great competition with the formal accountability mechanisms in the district. The formal accountability forum between the councillors and the bureaucrats is weakened by similar 
networks and are constantly shaped by the informal accountability mechanisms in ways that favour the provision of private goods in kinship networks.

\section{Patron-client exchanges}

Clientelism takes a variety of forms in different cultural settings (Brinkerhoff et al., 2002). The definition by Kaufman (1974:285, cited in Brinkerhoff et al., 2002) includes the following characteristics: (i) the relationship occurs between actors of unequal power and status; (ii) it is based on the principle of reciprocity, i.e. a self-regulating form of interpersonal exchange, the maintenance of which depends on the return that each actor expects to obtain by rendering goods and services to each other and which ceases once the expected rewards fail to materialize; and (iii) the relationship is particularistic and private, anchored only loosely in public law or community norms. Clientelistic exchanges are also politically motivated in that they involve the exchange of goods and favours for political support. I found three types of patron-client exchanges in Bunda: Councillors and wards, councillors and bureaucrats and the exchange between bureaucrats and politicians at the district level and those at the MoW and central government level in general. With respect to the first type of relationship, the councillorship institution is infused with traditional notions of a chief, headman or head of family. The councillors are expected to treat ward members as children (ensuring that they are well fed, treated when they get sick, get decent burial ceremonies in case of death) pay their school fees and play many other kinds of rational/informal roles (Field data, 2013-2014).

The second kind of relationship involves the councillors and the bureaucrats engaging in a patron-client exchange. Therefore, the bureaucrats are patrons who provide financial and nonfinancial resources to the councillors to prevent them from challenging motions tabled before the district council for discussion. On the other hand, some of the councillors, who are clients in this case, own private companies in the sectors of water, education, road construction and agriculture. During the tendering process, such people collude with the bureaucrats in the council to win the tenders. Thus, there are reciprocal obligations between the bureaucrats and the councillors which structure the behaviour of both outside the formal service delivery mandate. Explaining this situation, one respondent said, "Most of the councillors own private companies, including procurement, construction as well as consultancy firms and NGOs. This type of practice affects the councillors' capacity to question or monitor the activities of the executive because they collude in the tendering processes" (Field data, 2013-2014). Another respondent, who is a senior bureaucrat in the district, further explained that the councillors collaborate with the bureaucrats in their own interest. The relationship provides some benefits to each side." Giving an example of this in order to reflect what happens in the council, he said, "You give me a tender to construct a road or a water well so that I support your health/water/infrastructure budget when you table it before the council meeting... The councillors engage in dirty business deals. They own a myriad of businesses registered either under their own names or their relatives' or close friends'... When the executive advertise tenders relating to, say, road or water projects, the councillors would ensure that they get the tenders" (Field data, 2013-2014).

The third type of patron-client exchanges in the district involves district and central government officials. Here, the forms of relationships are vertical involving senior officials in the water department and those in the ministry of water and central government in general and based on mutual interests. Interviewed respondents said that executives and some councillors have established coalition networks with central government officials based on reciprocity obligations. Commenting on this, one respondent said: "council officials have personal 
connections with officials in the MoW and political figures in central government. The connections are based on economic interests in rural water supply projects i.e. influencing officials responsible for rural water supply to give water projects tenders to family and friends in the district".

In addition, citing one of the senior top government official from the central government who had worked as the Minister in the MoW and later on as a Minister in the President office, the respondent said that the district officials who are connected to the bigwigs are more responsible and accountable to this official that to the district council. This view is reinforced by a member of parliament from one of the constituencies in Bunda district. Speaking in a parliamentary session in 2014, he said: "there is a systematic and instutionalised network of corruption implicating central government officials in the ministry of finance, Prime Minister's OfficeRegional Administration and Local Government (PMORALG) as well as all sectoral ministries including water, health and education where some officials in these ministries collude with unscrupulous local council officials to embezzle development funds for personal interest".

\section{Rent seeking}

Rent seeking is often used interchangeably with corruption (Rose-Ackerman,1995:2). The difference between corruption and rent seeking is that while corruption involves the misuse of public power for private gain, rent seeking derives from the economic concept of "rent" earnings in excess of all relevant costs, including a market rate of return on invested assets (ibid). Contrary to widely held assumption that individuals are rational beings and often act to fulfil public interests, in the context of rent seeking this assumption is flawed in that "ruling elites, politicians and bureaucrats are utility-maximizing actors who pursue their own interests not only in private activities but also when making public decisions'” (Fischer, 2004:3).

I found that in Bunda district rent-seeking is a product of an informal institution like kinship bonds and reciprocity obligations which allow self-serving behaviour to kick in. Interviewed respondents indicated that councillors sought political office to obtain resources in order to govern their communities. Explaining this phenomenon senior respondents said: "at a family level a person may face difficulties to be responsible for his family when he has financial problems...if you are a teacher, for example, and you are in that situation...when you are teaching you think about your kids who did not eat anything the previous night; their school fees; you think about where to find money to buy medicines for your sick children... consequently, you can't teach. Instead, you will go somewhere to seek money to meet your family's needs ... sometimes you don't get the money, thus you ask someone to lend you some... immediately you stop thinking about those needs, but rather you focus your thoughts on how to repay the loan... these challenges prevent a person from being responsible and accountable" (Field data, 2013-2014).

Loans acquired by councillors were another constraining factor for councillor's oversight function over the executive. According to interviewed respondents, during the 2010 local government elections, Cooperative Rural Development Bank (CRDB) offered 5million Tsh to each councillor as a loan to facilitate their campaign trails. The loan was to be paid in a span of five years. Explaining on this point, a senior respondent in the district said: “...Each councillor earns a monthly allowance of 220,000Tsh (87 euro). This monthly allowance is not sufficient to repay the loan that doubles with an interest rate in a span of five years. If a councillor takes half of his allowance to repay the loan it would take even more years to pay the debt. 
This financial predicament combines with other expenses that they have to meet in their respective wards; they have to pay for school fees for poor kids, feed them, put fuel in their motorcycles, attend funerals and contribute consolation money to the deceased families, feeding their own families, educating and treating them when they get sick - all these expenses have to come from the meagre monthly allowance they get. As a result councillors would need to find alternatives out of this financial predicament i.e. to get another loan from another bank to repay the loan or engage in corruption activities for survival purposes. The latter is the dominant practice in the council (Fieldwork, 2013-2014).

Explaining these views in the context of councillor-executive accountability relations, the respondents said: "....If I am a politician serving in the council... and my role is to check on the performance of the council...yet my family is not financially stable. I will definitely start to look for financial gains which may not be legal/safe...if you start earning unsafe/illegal money...will there be accountability?...Imagine the council chairperson is paid 280,000Tsh (111 euro) a month, a councillor gets 220,000 Tsh (87 euro) a month, District Executive Director (DED) who serves under the council chairperson during council meetings gets 2, 000, 000 (797 euro) Tsh a month ${ }^{28}$. Do you think when the DED gives say 500,000Tsh (199 euro) to Council chairperson and tell him to keep a blind-eye on certain malpractices, he will refuse? Everything is economically driven my friend..." (Fieldwork, 2013-2014). The respondent proceeded to explain that financial demands coming from family members and the constituency are very high. This situation obligate councillors to personally seek financial resources (from bureaucrats, politicians at the central government level and business men in the district) in order to finance service delivery undertakings in their respective constituencies (Fieldwork, 2014).

Not only such informal institutions are competing with the formal accountability mechanisms but somehow they are influencing the accountability relationships between councillors and local executives and determine which actions are taken to improve rural water supply. For instance the formal forum (in which councillors and local executives discuss information related to district budget and plans, including rural water supply) is usually the district council. However the forum is now extended to lunch places, district corridors, and informal site meetings. I observed councillors becoming more active engaging local executives in these informal forums than the formal ones. In one encounter while having lunch in a local restaurant, I observed the District Chairperson threatening the District Water Engineer to visit his constituency to fix water points which were not working. The next day the District Water Engineer went with a number of technicians to the area and promised to ask for funds from the DED to address the problem.

This scenario would not be discussed in the formal forum that brings together councillors and bureaucrats. Equally, I also observed councillors doubling as account holders and accountors at the same time, a practice which deviates from formal requirements i.e. councillors are required to hold local executives accountable. In this case, during council meeting, some councillors colluded with local executives to stage the show. They would be picked up to contribute on every agenda on the table in sort of neutral or rather positive way i.e. creating a picture that they can question the executives and at the same time ironically provide answers to the questions. For instance a councillor from $\mathrm{X}$ ward would ask a question about progress on the status of education, water and road construction projects, then a councillor sitting in the planning and financial committee as well as social committee would stand up and respond to

\footnotetext{
${ }^{28}$ One euro is exchanged with 2508 Tanzanian shillings
} 
the question. Under formal rules of interactions executives (who are respective heads of the education, water and construction departments) are supposed to be answerable to such queries for it is their formal professional mandate do to so (Fieldwork, 2013-2014).

Figure 15: Informal accountability mechanisms in in Bunda

(Source: Inspired by Bovens, 2007 and Willems, 2010)

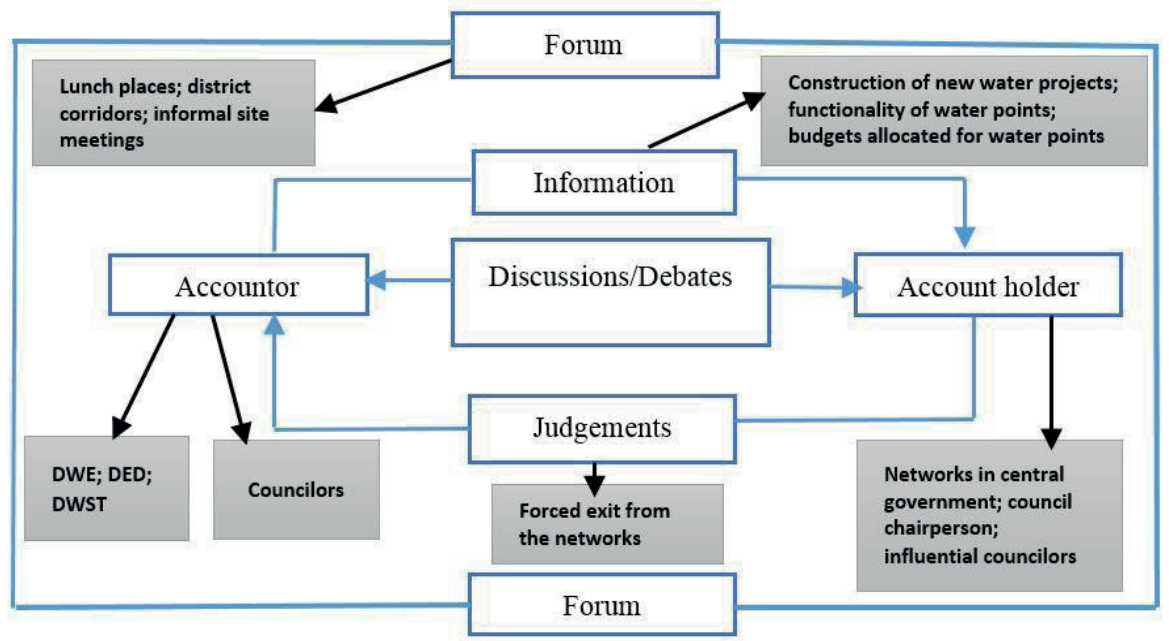

In addition to that, I observed that account holder's networks could extend as far as central government. For instance, a son of Minister X in central government who happened to secure tenders to construct new water projects in the District was more powerful than local councillors. Ironically, some councillors and senior local executives were more accountable to the father of the son within the central government network than the local district. I was informed by respondents that officials who somehow seemed to defy the odds by challenging this strong network of informal relationships were forced to exit the network by being transferred to other districts or demoted (Fieldwork, 2013-2014). A councillor explained to me how this works in the context of rent-seeking: "the former Minister of water influenced the recruitment of senior district officials responsible for rural and urban water supply. He maintained close relationship with the two officials even when he was appointed into another senior ministerial post. Following the introduction of the ten-village water projects in Bunda district under the auspices of the Water Sector Development Programme, he made sure that his son wins the tender to construct water projects in the selected ten villages ${ }^{29}$. With his huge influence in the tendering process - using the local networks - the son won four water project tenders in the 10 villages schemes worth billions of money".

The story of the councillor is affirmed by other respondents whom I interviewed. According to these respondents: "the son of the Minister had never successfully completed any of the water

\footnotetext{
29 The ten-village water project is a donor driven project aimed at constructing new water projects in local governments in Tanzania. The project requires district authorities to select ten villages which they think are mostly needy of water services. Bunda district is a beneficiary of these projects. The projects are supported by international donors through the Water Sector Development Programme.
} 
project he was assigned to construct. When few bold councillors (mostly from opposition parties) and administrative officials question his performance a group of loyal councillors to the minister would come in defence". The respondents also explained that the MoW play a role in the tendering process: "all the tenders are planned and executed at the MoW then imposed at the district. Theoretically the process appears to be district-grown but practically it is influenced by powerful informal networks from the national level". Another senior administrative official who happened to be a board member in the tendering process explained: "procurement of equipment and spare parts for water projects is not transparent, it is done behind closed doors. There is a lot of secrecy in the procedures involved in the preparation of bill of quantity. Buying of substandard spare parts is a common phenomenon in Bunda district. The tendering process is not transparent and characterized by corrupt practices. Central government officials influence most of the council decisions on tendering, procurement and staffing".

Notably, in Bunda district, rent seeking also occur where on the one hand resources meant for the development of rural water supply projects are pocketed by a network of unscrupulous administrative and political officials within the district in collusion with those in the central government and yet at the same time there is blame game that money do not arrive on time or they do arrive but in meagre form. Interviewed respondents pointed out that a significant portion of financial resources meant for rural water supply is lost in the pockets of unscrupulous officials. The ten-village water projects supported by international donors in Bunda district are not completed despite the fact that money was allocated. The ones that have been completed, usually water is not flowing. For instance a respondent noted that: "water projects are completed but water is not flowing...there is collusion between politicians and administrators at the local and central government level as well as consultants/contractors working in the district with central government officials".

Other respondents link the problem of completion of water projects with corrupt procurement procedures in the district: For instance a respondent in the water department noted "...I don't agree with the existing procurement system at all. There is collusion between procurement officials at the district and selected spare parts shops in Bunda town and Mwanza. If a market price of a spare part is 100,000 Tsh (40 euro), it will be overpriced two or three times and the cut is shared among the officials... Worse still the bought spare parts will not have required standards and would not last long before they burst or come to halt..." The respondent further expressed disappointments with the tendering board of the district noting that: "...Usually a tender board will elect evaluation team comprised of water officials, construction officials and planning officials. The list comprises of four to five people. The board may act with a great sense of professionalism but usually is side-lined by procurement officials because the latter have access to money. Councillors interfere in the tendering process especially on who should be awarded the tender. Under such circumstances bribes are paid to influence the process. Sometimes we are forced to give tenders to incompetent contractors..." The views of these respondents show that rent seeking is a dominant phenomenon in Bunda district and extend to as far as informal networks at the central government level. As a result local accountability practices are largely determined by these networks, which are driven by rent-seeking.

Respondents also explained cases of incompetent contractors who collude with district officials for rent seeking activities during the tendering process. A respondent explained that: "...contractors present fabricated documentation showing that they have the needed professional experiences, including sound financial statements and equipment's to deserve tender award but in reality when they are given the actual job they become bankrupt 
immediately...this, not only delays projects completion but also result in poorly finished work. In four villages water projects were constructed using substandard pipes resulting in frequent bursts of water pumps". These responses are also noted in the audit report commissioned by the central government in 2015 to conduct audit of the local government performance in regard to the WSDP.

In the area of contracting the report noted: "work measurements are not done before payments are made to contractors. The audit revealed that LGAs do not regularly carry out work measurements exercise before payments are made to the contractors upon submission of their claims contrary to best practice in the industry". The report further observes: "...WSDP projects at LGAs and water authorities are not properly designed and analysed before they are approved and implemented. The audit identified cases of abandoned WSDP projects before they were completed and put into use in favour of new similar projects implemented through other program funds...The audit revealed that WSDP projects are not consistently coordinated to avoid duplication of efforts from the project design to the implementation stages hence loss of value for money to the programme. The loss to the programme in this case is estimated at $325,000,000$ Tsh (129 euro)".

Rent-seeking is a prevalent phenomenon in Bunda district and arguably closely associated with corrupt practices where district officials, including bureaucrats and councillors in the district and officials in the central government who collude to obtain resources through strategies of extraversion as explained by respondents above. As a result accountability practices in the context of rural water supply are largely influenced by these informal network of relationships.

Moreover, the rent seeking practices in Bunda are also reinforced by international donor role on the rural water supply in Bunda, which affect accountability practices as well. The presence of international donors in the rural water sector in Bunda is clearly visible. The role of these donors in Bunda has been to construct new water infrastructure and hand-over to district officials for the routine management. However, the district officials, in turn, hand-over the projects to Community Water Supply Organisation (COWSO), a statutory body entrusted with the responsibility to manage rural water supply at the village level.

The donor's decision to build new water projects is based on the fact that the coverage of water supply services will increase and more people in the rural communities will have access to water. This situation has incentivized the district officials and councillors to also pay attention to focusing on new water projects. To district officials and councillors, new water projects provide an extra source of income because they get an opportunity to travel across villages to inspect progress of the water points being constructed and get paid lucrative amount of money that they would have not got if they stayed in their work places. However, this affect accountability practices between councillors and the executive officials. Councillors cannot hold the executive to account on old projects. The priority is on new water projects which the donor support. When I asked a senior respondent about old water projects which are increasingly being abandoned, and which could simply be renovated at a cheaper cost to serve the community, he explained to me that "We are aware of that, we will renovate the dysfunctional water points soon as money become available...for now the available budget from donors focuses on new water projects". The focus on new water projects, incentivized by international donors, not only affect accountability practices but the sustainability of water projects also, both new and old, will eventually come to a halt. 


\section{Political interference}

I found that political interference in Bunda manifest in the interference of resources slotted for senior district water supply officials. These resources are usually meant to enable officials in the water departments execute their responsibilities. Such resources include: personnel, vehicles, and money budgeted for rural water supply projects. According to respondents, senior political leadership in the district interferes in the work of rural water supply department by diverting and taking resources that were meant for the department's work on water projects.

This situation contributes to reducing efficiency of the rural water supply department. In one case, a senior respondent in the water department explained: “...I usually have my to do list written every morning when I come to office - thanks to my blackberry phone for having 'a daily planner application'. For instance today my to do list tells me that I had to visit water projects in the villages because they have reported water related problems, checking the status of new water projects, meeting with consultants and contractors etc...but the District Commissioner has taken the vehicle - for his personal use - which I usually use to inspect these projects. The vehicle belongs to my office, it was provided under the Water Sector Development Programme for rural water supply department. And this is not the first time. The villages are in remote locations I can't reach there without reliable transport. At the end of the day I fail to achieve my plans..." (Fieldwork, 2013-2014).

Respondents also explained that financial resources meant for rural water supply projects are sometimes diverted to finance personal political campaign trails particularly during intra-party nominations within the ruling party and the general elections. A senior public official was fired by the central government when he refused to divert funds slotted for the construction of water projects to finance the political campaigns of an influential politician during the intra party nominations within the ruling party. Explaining this scenario he said: “...As we approach the general elections this year a lot of terrible things happen...if you are a DED and you fail to mobilize local support for powerful presidential aspirants within the party you will definitely be fired...the support include diverging part of the disbursed money meant for development undertakings in the district, including water, education, and health to the candidate's personal bank account or his campaign team management...this goes as far as lobbying local business personnel, local politicians, senior administrators to finance the presidential intra-party nomination campaigns..." (Fieldwork, 2014).

The respondent said that he was perceived as an obstacle for failing to facilitate the mobilization of funds for some influential presidential aspirants within the ruling party. Equally, the respondent explained that when the ruling party loose an election to an opposition political party the DED is held accountable because he has a political role in the District, working as the director of elections. By virtue of this position they are better placed to influence election results in favour of the ruling party despite being prevented by an act of law from engaging in politics. For instance, the Public Service Act No. 8 of 2008 prevents all public servants of the United Republic of Tanzania, including DED's from engaging in politics. During local and central government elections, senior officials in the central government who are members of the ruling party, instructs all DEDs to act in favour of the party and ensure that opposition leaders do not gain any seat in the District and Village Councils. However, in the 2014 local government elections opposition political parties increased their share on the number of seats is the District. According to the respondent, this situation triggered anger among officials in the central government who decided to sack him. However, the official script given by the Minister 
responsible for local government authorities regarding the firing of this respondent had to do with bad performance.

Another area of political interference manifest in the state/government-party fusion. The state/government-party fusion is a dominant phenomenon in Tanzania. The state is so much fused with the ruling party and uses this powerful informal institutional arrangements in the daily governance practices of the country. The party structures are informally present from the District, Regional and the MoW. A parallel system of accountability relations therefore exist between District, Regions and the MoW. One being formal which follow the vertical and horizontal chains of accountability structures - in a decentralized context from central government to local government authorities - and the other is an informal one that exist alongside the formal structures. The party structures exist to ensure clientelistic goals are attained.

This scenario complicates accountability relationships by demanding information on rural water supply outside the formal context of information flow for political purposes creating informal political networks based on clientelistic practices. Respondents opinionated that party ranks within the District, the Region and central government demand information pertaining to rural water supply i.e. functionality of water points to account for the party performance to voters regarding the water sector.

The informal party reporting structure is not formally recognized in the formal reporting requirements that district water officials have to adhere to. Once accepted, the reports are submitted to the Regional Secretariat which forwards them to the Regional Administrative Secretary (RAS). At this level the reports are aggregated district wise then sent to the MoW. The information is reported on quarterly and yearly basis.

The accounts by respondents show that public officials in the water department in Bunda District have an informal role of preparing report that goes up to the district, regional and national party ranks. The reports have to be prepared in the context of the ruling party election manifesto on water targets. For example, senior district administrative official in the water department responsible for information collection opinionated that: "the department of water collect a lot of information, some of which are not even needed by the water department...such information is collected to fulfil the requirements of the region and the MoW and not the district's...". Likewise, the respondents expressed concern that “...they feel overburdened by the information collection roles and reporting to higher levels which derail them from focusing on other responsibilities as per their formal contractual mandates...the reporting formats and information collection formats are impossible to handle especially in the context where the party interfere in our work...".

The reporting requirements make district officials to informally incline to upward accountability to the central government. In this case local councillors do not stand a chance to hold local public officials to account. Equally as a way of balancing the party vs formal professional reporting mandates, district officials respond by sending data whose reliability and accuracy is questionable. Thus, the tension between informal party structures and formal bureaucratic reporting procedures makes district water officials to prepare reports to please higher authorities. The result is the compromise of data quality and reliability, which in turn, affect accountability. 
Party caucus is another area where political interference manifests itself. Traditionally, party caucus has been an integral party of a mechanism through which political parties strategize and securitize policy positions before presenting them for debates with other political parties in a parliamentary forum at the national level or district council forum for the case of local level. Through observation and interview with councillors it became clear that during council meeting, councillors (from the ruling party) appeared to have been given instructions from their parties to stage the show. They would be picked up to contribute on every agenda on the table in sort of neutral or rather positive way i.e. creating a picture that they can question the executives and at the same time ironically provide answers to the questions. For instance a councillor from $\mathrm{X}$ ward would ask a question about progress on the status of education, water and road construction projects, then a councillor sitting in the planning and financial committee as well as social committee would stand up and clarify the concerns.

Under formal rules executives are supposed to be answerable to such queries for it is their professional mandate do to so. Commenting on this practice respondents from the opposition political party said: “...Councillors from the ruling party and bureaucrats meet prior to council meetings in party caucuses under instructions and directions from the senior political and administrative ranks to deliberate on all controversial issues e.g. failures to implement projects. Thereafter, outspoken councillors (from the ruling party) would be given the task to keep things under control in case the opposition councillors raise queries. They would be picked to speak on the pertinent issues even those that were under the prerogative of the bureaucrats..." Another respondent said that councillors are paid lucrative sums of money to pass budgets and council plans that are not feasible and do not even reflect local priorities and needs. Explaining on this further, he said: “....There is a tradition in the council to mobilize ruling party councillors in a chamber prior to council meetings and pay them lucrative sums of money to oppose and undermine any proposal, no matter how feasible it is, from the opposition councillors. Even those with true spirit to question council budgets and plans would not manage to do so because they are betrayed by the money mongers. In one incident I challenged this practice only to be isolated politically in the council. I recalled when I withdrew my membership from the finance committee councillors pointed a figure at me and were surprised why I ditched such lucrative post..." (Fieldwork, 2013-2014).

\subsection{The influence of transnational policies and governmentalities on local water governance: the case of BRN programme}

Over the last decade Tanzania has seen a series of policy transfers where rationalities and technologies from other nations have been implemented to improve the service delivery capacity of the public sector. A recent experience in this area is the Big Results Now (BRN) programme launched in 2013.The BRN programme is touted as a transnational policy adoption that will transform the public service into being result-oriented, accountable, and responsive to the needs and aspirations of the citizens. The programme is based on the intention to fast-track the delivery of public services, including water. The overall objective is to achieve 'sustainable results' in the public sector. It is exactly this focus on achieving results that has pushed national government officials to start looking for approaches from other policy environments in addition to those often prescribed by traditional western donors. Meanwhile, western donors still have great leverage in influencing how the BRN programme is designed and implemented. While much has been written about other instances of policy adoptions in Tanzania, very little is known about the BRN programme. In this section I will describe how the BRN programme affected accountability structures and practices at the local government level. 
In order to describe how the BRN programme influences accountability practices and local water governance in general, I first describe the BRN organizational arrangements. The BRN programme consists of three delivery levels: leadership, governance and prioritization; performance management and problem solving; and implementation and service delivery level. The first level comprises of a structure called Transformation and Delivery Council (TDC). This structure is chaired by the President and is designed to be a think tank for providing a planning direction to the BRN programme ensuring the contribution of all relevant institutions and individuals for achieving the developmental objectives of the BRN programmes. It is also tasked with the function of approving National Key Result Area (NKRA) implementation plans, Key Performance Indicators (KPI's) and budgets as well as being a source of problem solving action for the programme as a whole (BRN Annual report 2013-2014:4-5).

The second level is managed by a unit within the office of the president. The unit is called President Delivery Bureau (PDB). It is mandated to support the President in overseeing the implementation of BRN projects and initiatives. Some of its key functions include: assisting the government in identifying NKRAs and developing implementation programmes for quick and impactful results; supporting Ministries in finding solutions to NKRA implementation challenges; and monitoring implementation of approved programmes and reporting on the results (BRN Annual report 2013-2014:4-5). Designed as it is, the structure largely hives-off ministerial powers to the president office. This is a continuation of the policy by the presidency to concentrate and centralize all governmental powers into the hands of the President - a practice that is very much facilitated by the current URT constitution of 1977 which gives power to the president to constitute and abolish any public institution.

The third level consists of three structures: the BRN Lab; steering committees and Ministerial Delivery Units (MDU). The BRN Lab is designed to be a think tank organization tasked to find solutions to complex problems based on clear and rigorous analysis and prioritization to develop detailed implementation plans with measurable Key Performance Indicators (KPI's). A steering committee involves key stakeholders for delivering the NKRA's and KPIs, and it is chaired by the respective Minister. The main role of the committees is to facilitate problem solving within the NKRAs. Any issues that cannot be resolved at the Committee's once-amonth meetings are escalated to the TDC. Ministerial Delivery Units (MDUs) are established in each NKRA Ministry responsible for delivering the KPIs and report directly to the respective Ministers. They support the NKRA Ministry by overseeing implementation and seeking resolution of potential bottlenecks and preparing implementation reports for the PDB on a weekly basis (BRN Annual report 2013-2014:4-5).

It may be discerned from the above BRN delivery structure that the $\mathrm{BRN}$ programme is a centralized top-down initiative designed to intervene in ministerial competences and to collect information from lower levels of government. The present structure creates no space for regional and district officials to somehow directly participate in identifying and diagnosing problems afflicting their localities. This raises questions as to whether district and regional officials were/are involved in choosing the objectives to be achieved by the programme. Instead, regions and districts appear to be users of BRN requirements that they did not help to produce, and on the flipside they produce information that they will probably not be able to use in their own context of improving rural water supply. 
As a result of the introduction of the BRN programme in the water sector, accountors and account holders at national levels (highlighted in red, figure 16) have doubled to set up national level institutions which previously did not exist. Accountors at the national level presently include: the President, the PDB, the MDU and the TDC, all of them demanding accountability from regions and districts. The structural re-organisation and re-centralization has incited local governments to focus on upward accountability. In case of water service delivery, the MoW demands more accountability from the regions and districts rather than devolving such processes. The higher level institutions such as the PDB, MDU, and TDC buy into the same logic of accountability. The consequences of this practice is the weakening of local accountability practices of councillors and the local government executives. This situation imposes 'consensus' on the rural water supply because local government officials are not holding each other to account, instead the focus is the national level.

\section{Figure 16: National, regional and district accountability chains in the water sector after the BRN Programme}

(Source: Authors construct based on field data)

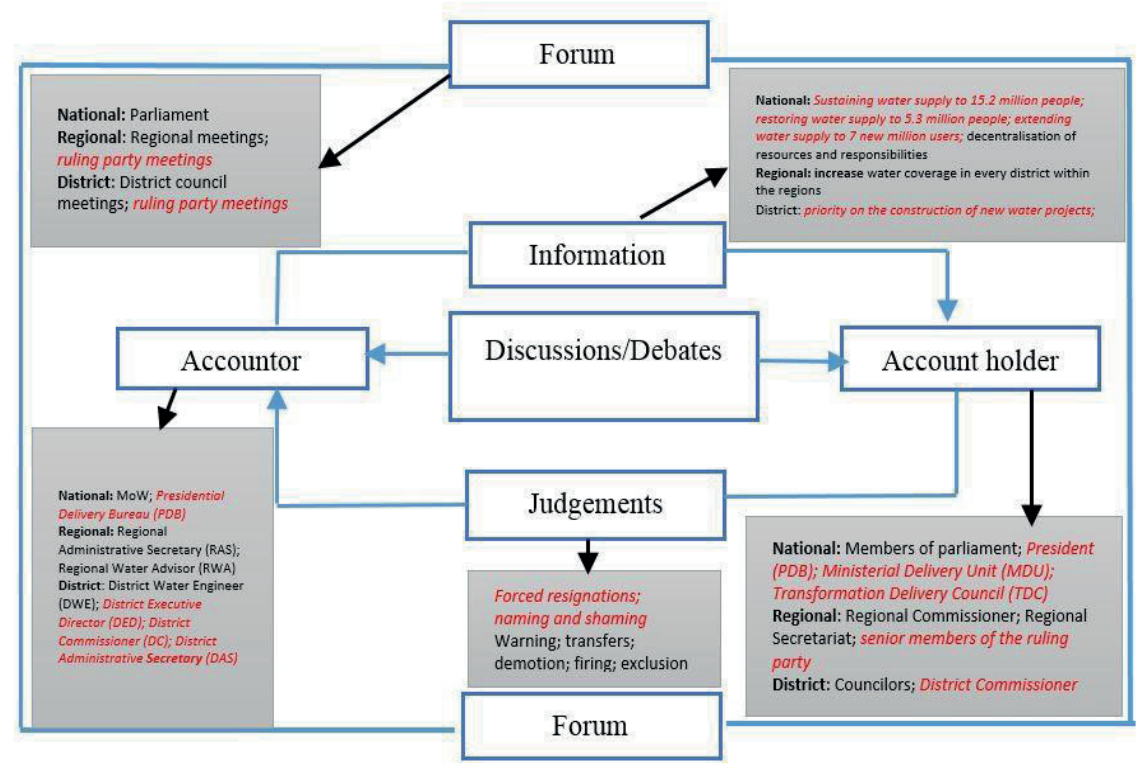

At the regional level the structures have remained intact, but with new accountors affiliated with the ruling party. Another consequence of the BRN re-centralisation move is that national level organisations, i.e. the MoW, MDU, PDB etcetera demand accountability from lower level organisations without transferring resources. Nevertheless, the ruling party structures (at regional and district levels) have become part of the recentralization move as well. Bringing party structures into what is considered as a typical professional undertaking, not only exacerbates further centralization but also undermines the credibility of professionals who are responsible for the BRN programme. 
A notable example of the BRN re-centralisation move is the introduction of new structures consisting of technical labs for diagnosing problems and solutions in various public sectors, including the water sector and delivery bureaus housed in the ministries and the president's office. Government officials welcome these structure believing that they will ensure effective and efficient management of the water sector by fast-tracking implementation bottlenecks of water projects. In fact, public officials have linked the introduction of labs and bureaus with successful implementation of the KRA of water. For instance, the BRN implementation report of 2014-2015 in the KRA of water explains that "the Ministry of Water's strategic and prioritised approach to water infrastructure projects provided more people with access to water in one year than ever before. The provision of 9,452 additional water points resulted in 2.36 million people in over 240 villages gaining access to water. This performance is significant compared to the previous achievement of reaching an additional 300,000 to 500,000 people on average per year- Water 80 \%” (BRN Implementation Report, 2014-2015).

However, interviewed respondents suggest that the BRN programme objectives are not being implemented as planned because the central government does not transfer resources to local governments to implement development projects. However, this framing disguises the true picture on the ground, for they at the same time acknowledge that the transfer of resources is a problem highlighted to mask the bigger picture of extraversion games. Thus, the BRN programme is anchored on a corrupted non-performing system of decentralisation by devolution in the water sector. The result is conflicting governmentalities: one that works through strategies of extraversion favoured by public officials, and another that works through NPM-induced reforms favoured by donors. The two are always in conflict and affect local government accountability practices and local water governance in general.

\subsection{Discussion}

The findings in this chapter show that formal accountability mechanisms in Bunda are weak. The much stronger informal accountability mechanisms exist in parallel and compete with formal accountability mechanisms. Equally, the findings show that informal institutions obstruct the provision of access to water, and allow politicians to engage in strategies of extraversion. These findings show that in weakly institutionalized contexts, informal accountability mechanism compete and structure officials behaviours in a manner that is incompatible with formal service delivery mandates as demonstrated in the rural water supply sector in Bunda. While this remains largely the case, the BRN programme is imposed on a corrupted non-performing system of decentralisation by devolution. This increases opportunities for strategies of extraversion by public officials but also in the long run affects the delivery of rural water services.

However, these findings need not to be understood in a vacuum. Two important contexts are critical to grapple with. First, the present accountability practices in Bunda district owe their explanation to the historical governmentality from pre-colonial, colonial, and postindependence influences. Each period was marked by governmentalities which shaped and guided the conduct of the society and the rulers. For instance the pre-colonial governmentalities formed the basic foundation of ideas regarding power, morality and accountability. These ideas, in turn, created a social fabric that informed the conduct between the African decision makers on the one hand and the community on the other. Although colonialism introduced its own governmentalities based on the indirect and direct rule systems of governance, the pre-colonial governmentalities remained firm. Once the colonialists left, as Goran Hyden indicated, there 
was not enough of a critical mass to reproduce the colonial governmentalities (Hyden, 2008:8). As a result after independence, the resurgence of pre-colonial R-M-Ts emerged as part of a broader emancipation of Tanzanian culture, values, traditions and norms interwoven in the social fabric. Since then, such resurgence has become part of the political process which has continued to exist even to date, as confirmed by the findings in Bunda.

Kinship bonds, patron-client exchanges, and rent seeking derive their roots in the R-M-Ts present in the pre-colonial period. Kinship bonds in Tanzania, particularly in rural settings are very persistent. The bonds are built on the basis of beliefs, customs, traditions, and values binding members of a particular family, clan or society together and inform their conduct in ways that reflect how they think of themselves. Usually, the rules regulating the members conduct are strictly informal, unwritten and often subjected to negotiations to fit prevailing socio-economic and political interests of the members. In addition, every member abides to the code of conduct and once this code is violated the member will be excluded from the group.

The local and political leaders in Bunda and the rest of the community understand these codes of conduct that have shaped the community for decades and have taken them as a way of life not to be questioned by any one. For instance, it is not a formal responsibility of a councillor to pay for school fees of children who are not of his own, but he has to do that because the society perceives the councillor as a father who has an obligation to pay school fees for his own children as well as the children of other members of the community. Failure to fulfil that obligation under 'personal capacity' constitutes a violation of an important code that ties the society together and may constitute punishment including being voted out of office in local elections.

Thus, it is usually upon the councillor to find ways to obtain the resources to provide for his community even when it means to break the formal rules. The members of the society do not care about the means that a councillor may use to obtain the resources to meet their demands. Understanding this situation, councillors engage in strategies of extraversion which take the form of patron-client exchanges and rent seeking to generate resources to meet the demands of their communities.

The practices of senior district officials interfering in the work of administrative officials often leave the latter without the necessary resources to carry out the work effectively. Equally, in most cases party caucus in Bunda always acts in favour of senior administrative and political leader's interests rather than those of the general populace. Furthermore, the relation between the central government and local government in Bunda is that of a blame game. Central government blames the District council for misusing development funds for personal gain while local government blames central government for delaying financial disbursements meant for development undertakings in local authorities, slotting a meagre budget to finance development activities including, rural water projects and the lack of autonomy in managing financial and human resources as well as planning. One example in the planning arena is the village planning framework technically dubbed as Opportunity and Obstacles to Development (O\&OD) - a bottom-up participatory planning methodology for local development which requires village government to prioritize development plans according to local needs and priorities. In practice, however, the central government determines what should be implemented in the district in line with national priorities. This makes politicians and bureaucrats to be more inclined to upward accountability which is ensured by the centrally appointed staff in the local governments (Venugopal and Yilmaz, 2010). 
Secondly, the influence of transnational policies and governmentalities on local water governance in Bunda district is largely a result of the NPM-induced reforms advocated by donors. However these reforms are working against existing governmentalities. In particular, the BRN programme is working against existing governmentalities. As a result, the recentralization move implied by BRN gives more power to the central government rendering the regions and districts powerless entities in the framework of decentralisation by devolution. This brings challenges at the national and local government levels, where NPM-induced rationality focusing on increasing efficiency and effectiveness is compromised by the mentality of 'centralisation' and 'strategies of extraversion' by local government and national government officials.

\subsection{Conclusion}

In this chapter, I have argued that in Bunda district local accountability practices in the rural water supply domain show informal accountability mechanisms that are competing with formal accountability mechanisms. The result of this is the structuring of both administrative and political officials' behaviour against the formal rules of the game, with serious consequences for rural water supply services. As a result, the councillors' oversight role over executives is largely determined by the informal accountability mechanisms, and these determine to a large extent which actions are taken in dealing with the rural water sector. The informal accountability mechanisms derive their origin from pre-colonial governmentalities which found their way into post-independence Tanzania. In the pre-colonial period autonomous societies and local governance systems were informed by indigenous rules. The German and British colonial rule altered the social fabric, to transform and manipulate the indigenous local governance systems to serve their interests. The result was the disorientation of traditional institutions and the social fabric that was to become the basic foundation of local governance practices, including accountability. The post-colonial administration re-organized the public administration structure by introducing the first wave of reforms centred on the local governance needs. However, the reorganization maintained much of colonial administrative structural tenets, including the centralization of power to a few national leaders and their close networks.

Meanwhile, whether by default or design, donors have continued to champion the reform agenda on good governance with a robust emphasis on formal accountability mechanisms and of late very scanty attention to informal accountability mechanisms. The HESAWA experience in the lake zone and the BRN programme described above should have provided enough lessons that interventions that ignore existing governmentalities have limited impact. Parallel to the donor reforms, the rural water supply delivery spectrum in Bunda is dominated by informal accountability mechanisms based on locally understood governmentalities which are out of sync with donors' governmentalities. As a consequence, informal, unwritten rules and norms originating from pre-colonial and colonial governmentalities are the main drivers of accountability while formal rules exist in a ceremonial fashion. National government officials and the international donors are increasingly advocating the use of Information Communication Technologies (ICTs), for strengthening accountability practices in the MoW, regions, and districts. In the next chapter, I examine the effect of such ICT-based accountability interventions in the water sector. 


\section{ICTs-induced accountability interventions: the case of the WPM system and the SEMA mobile phone application}

The role of data - created, transferred and modified - through Information Communication Technologies (ICTs), including mobile phones, in enhancing accountability is growing in Tanzania. In the last decade, ICTs have increasingly become embedded in formal accountability practices in the water sector, including the idea that in case of broken-down water points, data may be provided through ICTs, which help alert public officials to the problems (Pearce et al., 2016). Thus, the major thrust of digital data sources in the water sector is based on the assumption that accurate, reliable and timely information on water points is critical to the provision of sufficient data for planning, budgeting and identifying areas to invest in (Water Aid, 2008). This assumes that the sustainability of the existing water points can be ensured, and accountability of public officials can be enhanced.

In this chapter, I use two interrelated case studies of RWS MIS: the Water Point Mapping (WPM) system, managed by the MoW, and the SEMA mobile application currently being implemented. The research question I investigate is whether ICT/mobile phone-induced accountability interventions will be accepted by public officials in the MoW and local authorities as part of their Management Information Systems. I find that both SEMA and the WPM system got entangled in a larger web of influences: administrative level fights, interoperability demands of the $\mathrm{WB}$ and IMF, inter-ministerial fights, and mentalities/technologies of communication between citizens and state institutions. I argue that this 'entanglement' is the result of an interplay of opposing governmentalities: one informed by formal RMTs, which are advocated by donors and national government officials; and informal RMTs, which are ingrained in the daily governance undertakings of national government and local government officials. The national government officials, however, subscribe to donors RMTs for strategies of extraversion.

\subsection{ICTs and accountability in the rural water sector}

Information and communications technologies (ICTs) are increasingly seen as new avenues for citizens to hold service providers and government to account (Edwards and McGee, 2016). But the key question invited by these technologies is twofold: are citizens motivated to use ICTs to hold public officials to account? And are public officials willing enough to accept information generated through ICTs and mobile phones in their daily Management Information Systems (MIS) routine? This chapter focuses on the second question, but does not focus on the first one. The second question calls for a responsive dimension of accountability from public officials, i.e. will public officials respond to citizen's demands? The 2004 World Bank report entitled "Making Services Work for Poor People" has been the main point of reference in offering governance frameworks with regard to the framing of accountability relations between poor citizens and public officials in the context of service delivery and ICTs.

The report proposed two avenues for increasing accountability in service delivery: the "short route' of direct interaction between citizens and service providers to improve service provision, and the 'long route' of citizens putting pressure on policy-makers who influence service delivery (WDR, 2004). However, labelling a particular section of a population "the poor" and singling them out as the only actors to hold public officials to account not only disenfranchises other groups who can potentially hold public officials to account, but underscore the hegemonic representation of RMTs from donors in the water sector. 
The adoption and use of ICTs, including mobile phones, in the sub-Saharan Africa and Tanzania is fast. Over the past decade, the region has witnessed a quadrupling of the number of mobile subscribers and connections. In Tanzania, available figures indicate that the number of mobile phone subscribers rose from 3 million (10\%) in 2005 to 34 million (71\%) in 2014 (URT, 2014).

With increasing number of mobile phone users, the potential for facilitating new communication channels between government and citizens to improve governance and accountability is increasingly being acknowledged in studies about ICTs and governance (Dziodonu, 2010; Dickinson and Bostoen 2013; Georgiadou et al., 2011; Hutchings et al., 2012; Pearce, Welle and Dickinson, 2013; Pearce, Dickinson and Welle, 2015; Thompson, 2004; Welle, 2015; Wesselink et al., 2015). This is part of ICTs' imagined promises of good governance, including accountability (Wesselink et al., 2015).

In the area of government operations and service delivery, ICTs and mobile phones are increasingly transforming government operations from paper-based MIS to ICT-based MIS. Here, the potential of ICTs to establish an environment for improved service delivery as well as increased transparency and accountability is a major argument, especially in the discourse on trans-national policy agencies, to the point that it has become almost common place (Dawes, 2008; Klopp et al., 2013, cited in Sika et al., 2014; Ndou, 2004; OECD, 2003). In the area of water service delivery in particular, ICTs and mobile phones are believed to hold great potential to improve the collection and dissemination of data on water service provision and to provide new opportunities for monitoring and influencing policy-making (Welle, 2015).

However, there are also disagreements on the potential of ICTs to make governments more accountable (Fung, Gilmanand and Shkabatur, 2013, cited in Edwards and McGee, 2016: 42; Livingston and Walter-Drop, 2012). For instance, while technology-focused scientists highlight the transformative power of new technologies to transform democracy, political scientists are skeptical about it, and instead focus attention on underlying incentive structures and the role of institutions in influencing how transformative ICT innovations can open up existing social accountability mechanisms (Edwards and McGee, 2016: 42). In this context, incremental models of ICT engagement are seen as more likely to lead to transformative changes in politics (Fung et al. 2013, cited in Edwards and McGee, 2016: 42). In a similar vein, scholars who investigate the role of ICTs in the governance of service delivery are cautious about equating technology with greater transparency and accountability and call for a better analysis of the underlying factors affecting political changes (Josh et al., 2010; and Gigler and Bailur 2014, cited in Edwards and McGee, 2016: 43).

Furthermore, other scholars have indicated that, the fast diffusion of ICTs and mobile phones in the south and Tanzania in particular, has its side effects. The increasing digitisation of behaviours, relations and networks in the south in general has influenced the way populations are made legible in development cooperation, thus providing a power advantage to international donors who have access to such data to influence policies and programmes in the south (Taylor and Broeders, 2015:230). Equally, the 'New Public Management' and the 'New Governance' paradigms of governance propagated by international donors, including their imagined promises, are increasingly being embedded in ICTs and mobile phones in the south. The result has been a system of governance that connects the south and the north through what Castells, (1996) describe as 'informational capitalism'. In this system, information flows in circuits that serve the interests of powerful entities, both private and public, and where those who trade in 
information are able to modulate people's behaviour, activities, and relationships to the state (ibid). This in turn makes the state and its citizens more legible to the international donors allowing them to influence policies through bilateral and multilateral aid arrangements.

Against this backdrop, Tanzania has been experimenting with a number of ICT-based initiatives, particularly in the water sector, designed to monitor the delivery of water services at the local level, including enhancing transparency and accountability. These initiatives are intended to mitigate the challenges afflicting the rural water sector in Tanzania. The challenges include, but are not limited, to the number of water points that quickly become dysfunctional after few years of construction and information gaps between the district officials and villagers (Jiménez and Perez-Foguet, 2010; 2011; 2012; Mandara et al., 2013). These challenges are increasingly calling for measures from international donors, research organizations and national government officials to leverage on the use of ICTs and mobile phones to facilitate a wide range of service-related activities, including reporting failures of public services.

In the context of this study, the ICT-based initiatives in Tanzania focusing on generating data for improving service delivery and accountability can be put into groups: those focused on improving the internal working of the government, particularly the MoW. The focus has been on automatizing the back-office operations of the MoW from the paper based MIS into ICTsdriven MIS so as to monitor the delivery of water services effectively. The most notable initiative in this category is the Water Point Mapping (WPM) system of the MoW. The second group consists of front-office ICT initiatives, which are largely, mobile phone-driven, designed to improve the communication relations between the state and citizens. The front-office initiatives are aimed at amplifying the voice of ordinary citizens, improve citizens 'capacity to directly influence public service delivery and hold local government accountable' (Georgiadou et al., 2011). The main assumption is that empowered citizens, with access to standard mobile phones, can 'sense' via text messages and report failures in the delivery of local government services. The public disclosure of these reports on the web and other mass media may pressure local authorities to take remedial action (ibid). However, in the latter case, I focus on the responsive side of public officials i.e. the willingness of public officials to accept and respond to data on functionality and non-functionality of water points reported by citizens. I describe the WPM system and SEMA mobile application next.

\subsection{The water mapping system in the MoW}

The WPM system hosted in the MoW was created to replace the Rural Water Supply (RWS) database which was set up by international donors. The German Enterprise for International Cooperation (GIZ) set up the RWS database in 2001 in order to help the MoW gather information on existing water schemes in rural areas at the district and ward levels. The updating mechanism of the database was paper based - involving filling forms in the field and manually entering the data into a spreadsheet file. The RWS information system contained 2765 schemes and the last update was done in 2007 (URT, 2010). In 2004, the World Bank offered technical and financial assistance to the MoW to build a stand-alone IMS dubbed as MAJI's for the department of Urban Water Supply (UWS) in the MoW (URT, 2012). The MAJI's IMS was essentially an internal project management tool built to help the MoW administer its internal operations i.e. tendering, procurement and construction and financing of water schemes. Within it span of existence the MAJI's covered fourteen districts and was used until 2008 (Fieldwork, 2015). Following the inadequate local capacity coupled with technical problems in terms of system errors and bugs, the MAJI's IMS was dropped in 2008. 
The WPM system owes its origin from the Malawian WPM system. The mapping idea of water points in Tanzania came from Water Aid NGO as a result of the NGO's positive experience on mapping water points in Malawi (Water Aid, 2004). In 2004, Water Aid conducted piloting activities by mapping water points in 10 selected districts in Tanzania and finalized the pilot in 2005. The total cost of the WPM pilot phase amounted to US\$ 100.000 for the 10 districts. During the mapping exercise Water Aid contracted Geo-data (a local consulting company) to carry out mapping on Water Aid's behalf. The budget for mapping each district then stood at US 7500 per district regardless of its actual size. The start-up costs for adapting the WPM methodology to the circumstances in Tanzania amounted to US\$ 30,000 (Water Aid, 2008). Part of the cost included a trip by Geo-data to Malawi to familiarize itself with the existing methodologies (ibid). The time required for data collection per district amounted to approximately 15 days depending on the size of the district and the accessibility and total number of water points; data processing and analysis (Water Aid, 2008).

The outputs of this mapping exercise by Water Aid through the consultancy services of Geodata pleased senior public officials at the MoW and international donors who decided to institutionalize the process in Tanzania. Thus, between 2005 to 2010, international donors, including Water Aid, SNV, Plan International, Concern Worldwide, Ingeneras Sin Fronteras Engineers without Borders (ISF) and African Research and Medical Foundation (AMREF) mapped substantial parts of the administrative districts (55 out of 133) following the same methodology. Building on this experience, the MoW decided to adopt the WP Mapping methodology to conduct a comprehensive baseline study of all Water Points (WPs) in Tanzania. Beginning in 2010, Geo-data was appointed to complete the baseline. The development of the baseline was completed in 2013. Next, I describe techno-social assemblage put in place for the base line study.

The first task of the consultant was to assemble the right technologies and expertise for capturing the water point data (Figure 17)

\section{Figure 17: Technologies used in Capturing WP Data}

(Source: Nyitambe, 2013)

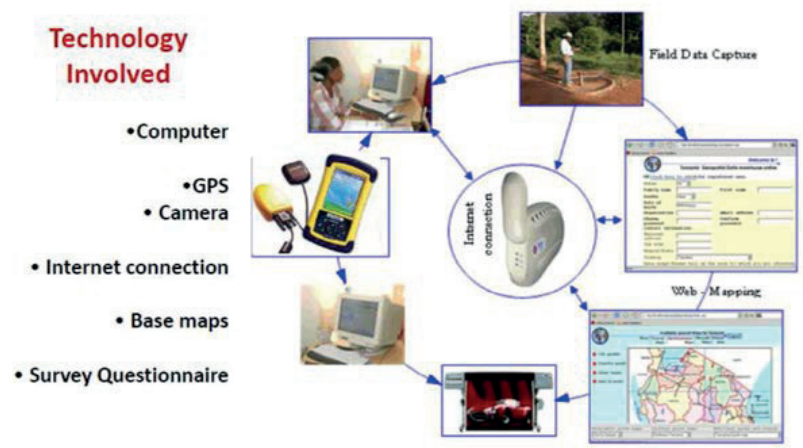

The consultant was required by the MoW to geo-locate each public WP using Global Positioning System; taking geo-tagged photographs of each WP in order to present the reality of the physical conditions; collecting data on the functionality, management, technical specifications, quality and quantity of water produced at each WP using a questionnaire; 
designing, developing and institutionalization of a functional web-based system to produce and make maps publically accessible and data relating to WP functionality and coverage ; and increasing the capacity of MoW and local government staff to be able to use and update the WPM system.

This long route for service monitoring that relies on information moving up the hierarchy in a paper form compromises the quality of data. This results in data becoming inaccurate and unreliable which in turn affects planning, budgeting and accountability preventing effective monitoring of service delivery in rural areas (Jiménez, A. and Pérez-Foguet, A. 2010; 2011; 2012). The information flow in the WPM system mimics the existing structures of central-local government information structures. The information flow starts with the Community Owned Water Supply Organizations (COWSOs) who send reports on functional and non-functional water points to the Village Executive officer (VEO). The VEOs send the reports to the Ward Executive officer who forwards them to the District Water Engineer (DWE) to verify and enter the data into the Water Point Mapping System at the district level then submit the information to the Ministry of Water for verification.

Figure 18: Information flow in the WPM System

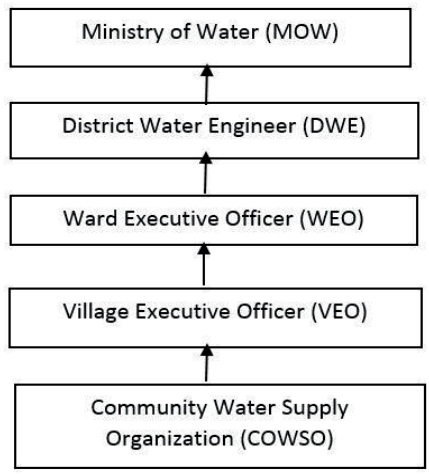

The overall responsibility of the MoW in this process is to ensure quality control and to upload mass data from the DWE on to the WPM system.

The information coming from the lowest level to the highest is then analysed and presented as charts, graphs and maps with the intention to be used for raising awareness about the responsibilities for operation and maintenance of water points to the communities. The charts, graphs and maps are made available in the website of the MoW. The website has two main sections: controlled user group menu which is accessible to officials such District Water Engineers; and the uncontrolled public section which is open to public view (Figure 18). 


\section{Figure 19: A snapshot of the WPM system website of the MoW}

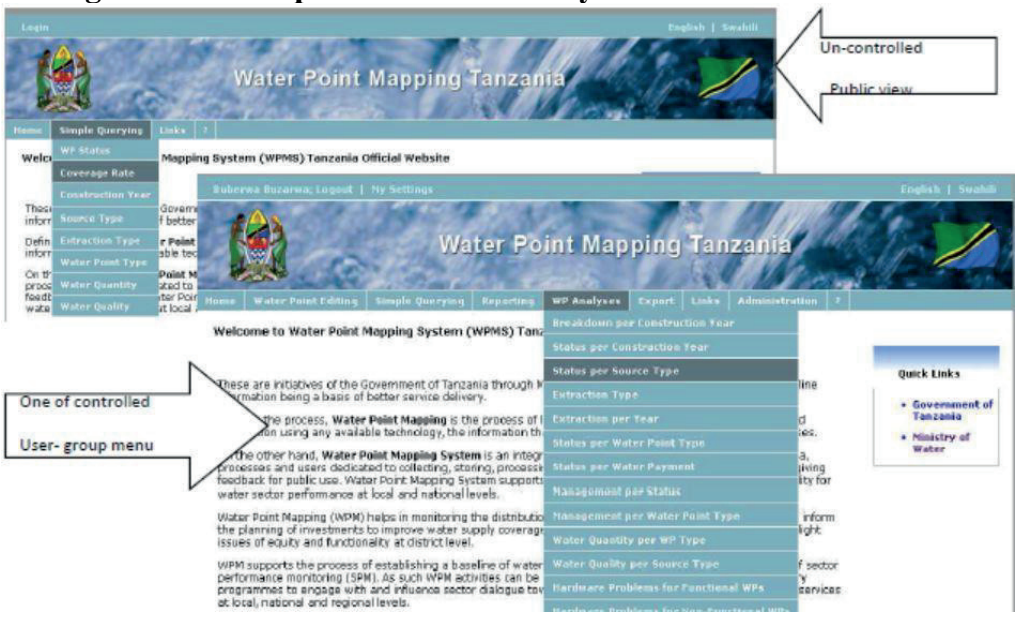

The website provides a list of regions and districts with corresponding number of functional and non-functional water points. The user select the region and the respective district to view the status of water points in the entire district or by ward category.

Figure 20: A Snapshot of the status of water points in Bunda district (Queried on 29-02-2016)

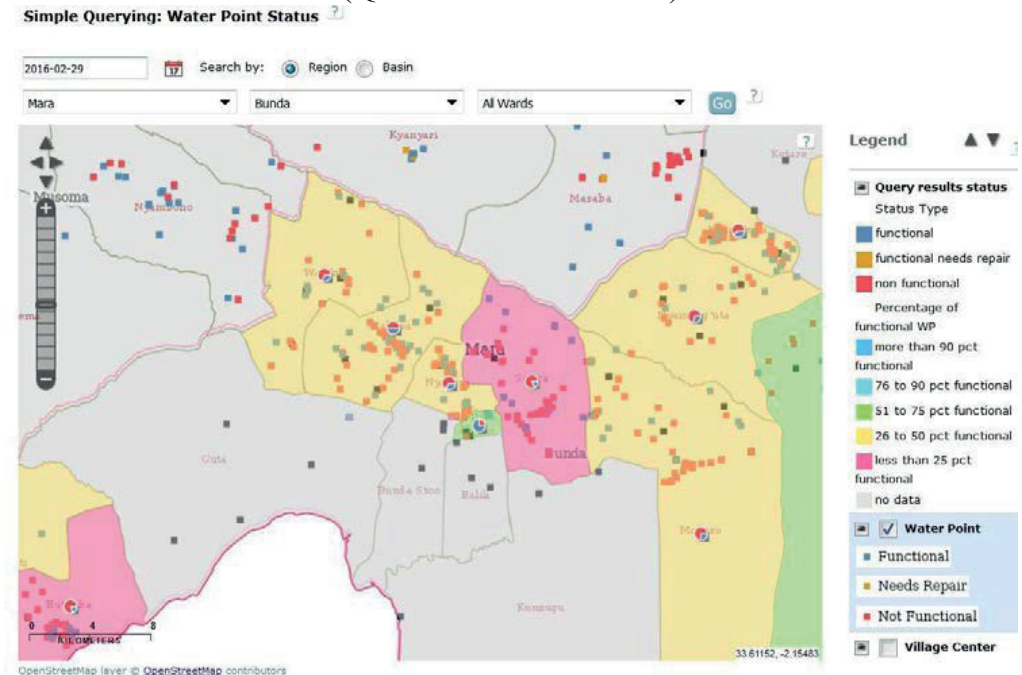

The WPM system also generates graphs indicating statistics regarding the status of functioning and non-functioning water points. The information is intended to help officials at the district, regional and local level to improve the functionality rate of water points in rural areas. At the District Level, the information is intended to be used by DWE's to support rehabilitation/repairing non-functional water points; prioritize financial and investment planning; promoting equitable resources allocation; planning (new) water point distribution; as well as a monitoring tool for sector performance (Water Aid, 2008). 


\section{Figure 21: A snapshot of the statistical graph generated from the WPM system on MoW Website}

Water point status for Bunda LGA

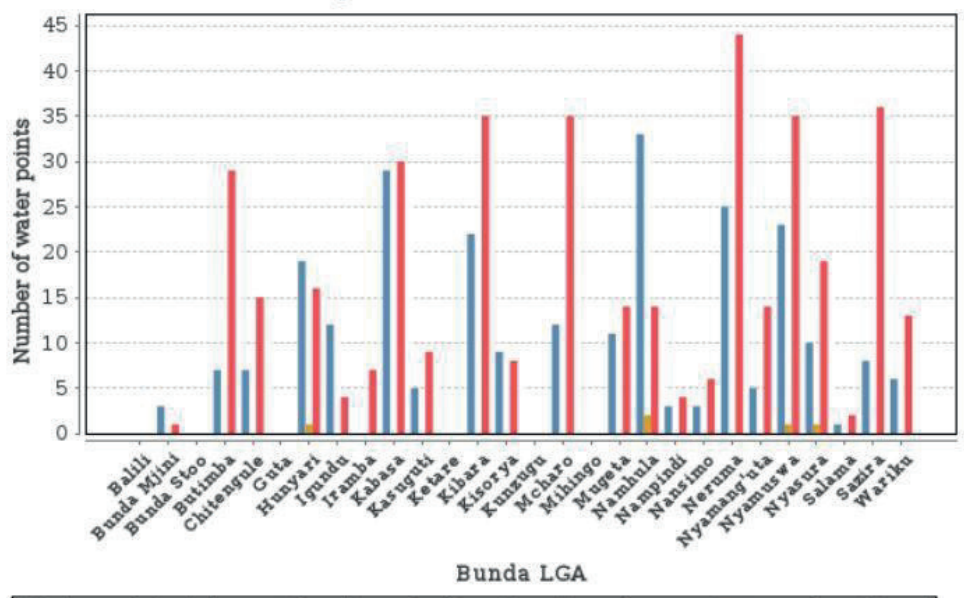

Water point status: $\mathbf{n}$ functional a functional needs repair a non functional

At National Level the information is intended to be used for influencing national policies and strategies; resource allocation and informed decision-making; prioritizing financial and investment planning; supporting national monitoring (Water Aid, 2008; URT, 2013). The overall objective is to support increased accessibility of information on the current coverage of functional and non-functional public rural WPs with the view of improving decision-making and allocation of resources leading to the improvement of water supply services in rural areas (ibid). Despite the fact the WPM data has been made accessible through the website of the MoW and can be used for all kinds of analysis, the WPM is not being regularly updated by the District water Engineers (DWEs).

\subsection{SEMA mobile phone reporting}

SEMA is a Swahili word that means "tell me". The acronym 'SEMA' stands for Sensors, Empowerment and Accountability. The Sensors Empowerment and Accountability (SEMA) research project is a joint research programme between two public universities: The University of Twente based in the Netherlands and the University of Dar es Salaam based in Tanzania. The research project started in 2012 and is expected to end in 2016.

SEMA mobile phone reporting platform draws its origin from the 'H2.0 Monitoring Services Inform and Empower Programme' launched by UN Habitat and Google.org, implemented in Zanzibar in 2009/2010. The rationale embedded in the 'H2.0 Monitoring Services Inform and Empower Programme' was that citizens would use their mobile phones to report the lack or poor quality of water at a public water point. This would be followed by data collection, anonymization as well as publicly disclosing the data in real time on the internet through Google maps to be viewed by stakeholders including, NGOs, government officials as well as citizens

(Georgiadou et al., 2011). The objective of publishing information was that once these actors get the right information on the state of water quality, the will take subsequent actions to solve 
water problems. However, despite the sophisticated architectural design and the overall wellthought-out vision, the project did not go without challenges.

Three challenges were identified as obstacles to the successfully execution of the project. The first challenge had to do with the kind of 'a hybrid of human and technological capabilities of a human sensor' i.e. it was noticed that 'citizens would often send SMS stories about the lack of water instead of texting the prescribed text (no or dirty)'. Eventually, the software could not pick up the SMS let alone understanding them. The second challenge was related to citizen reporting behaviour. It was noticed that citizens reported problems on water to independent parties, who they trust that they could forward their problems to officials, rather than directly reporting to official authorities. This situation led to the recognition that "other media and community channels may be equally more important for citizens than the HSW" (Georgiadou et al., 2011). Thus, there was a need to study more on citizens reporting behaviour. The third challenge had to do with attitudes of public service providers, in water and health care sectors, towards citizen reports. It was specifically noticed that officials did not have systematic mechanisms for tapping client information. It was therefore envisioned that public officials in the domain of water and health sectors could use Human Sensor Web (HSW) to tap on citizens as informants to report on water and health issues as well as independent verifiers of Public official's information. An HSW consists of a large network, or web, of people with mobile phones with specialised mApps, geoweb services to publicise and disseminate aggregate information, and users of the information (Wesselink et al., 2015).

The SEMA Research project was conceived to address the challenges emanating from the Zanzibar H2.0 Monitoring Services "Inform and Empower Programme" highlighted above. The research project is informed by the philosophy that "the relationship between citizens and government can be improved if citizens can report how they perceive the quality and availability of public services particularly water and health through the use of Human Web Sensor" (Georgiadou et al., 2011). At the heart of the SEMA research is the belief that the relationship between citizens and government can be improved if citizens can report ('tell') how they perceive the quality and availability of public services, via an innovative participatory sensing system, a 'human sensor web.' Reliable citizens' reports can help produce, together with government information, novel indicator systems to enhance the MDGs (ibid). The overall research goal of the SEMA project is to investigate to what extent ordinary citizens in Tanzania can, and will, participate directly in exacting accountability from public water and health providers with a human sensor web (HSW).

The initial design of the SEMA software consisted of two mApps which were to be used for reporting and receiving information limited to the current status of the water point (functioning/non-functioning) and the cause of non-functionality. The mApp, for low-end mobile phones (USSD) and for Android smartphones. The App is complemented by a backoffice database and querying system (Figure 22). 
Figure 22: SEMA mApp: USSD (left) and android (right) implementations.

(Source: Wesselink et al., 2015)
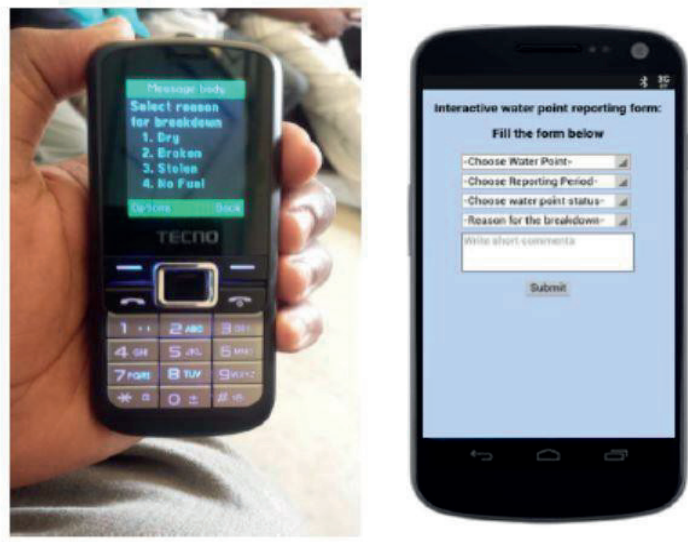

However, it turned out that the ownership of smart phones in Tanzania was substantially minimum to allow the use of smart phones for reporting particularly in rural areas. The lack of reliable internet services in the rural areas which could enable the use of smart phone for reporting was a significant challenge as well. The knowledge of rural communities with respect to the operation of a smart phone was yet another challenge. Thus, the USSD implementation became the default endeavour, and the Android App is developed in parallel with future use, and more advanced users, e.g. in the local authority, in mind (Wesselink et al., 2015). The functionality of the mApp was determined by the formulation of so- called 'use cases' that systematize who asks for information, what information is required and for what purpose (why). For example: 'as a water user, I want to know the nearest functional water point so that I can fetch water', or 'as a District Water Engineer I want to identify similar problems in my network so that I can understand common causes (ibid).

The SEMA Mobile reporting application seeks to update the WPM system of the MoW by reporting on functionality and non-functionality of rural water points. The mobile reporting platform aims to assist the Community Water Supply Organisations (COWSOs) and District Water Engineers (DWE) to execute the monthly RWS monitoring cycle of the water points. This entails monitoring of functionality and water quality through the use of mobile phones. COWSO members have the responsibility for monitoring while the DWE has the responsibility for reporting to the Ministry of Water (MoW).

\subsection{The research design}

A key element of the overall SEMA research design constituted learn-and-deploy cycles, where the SEMA software was developed and tested in an attempt to improve functionality and usability. My fieldwork was conducted during these deploy-and-learn cycles between 2013 and 2015 , and included some involvement in these cycles. The first round of field work involved learning the state of the art on existing practices with regard to information infrastructures and accountability in the MoW. The second round of field work focused on learning existing information infrastructures and accountability practices in Bunda district. The third round of field work focused on deploying and testing the software in the MoW and in Bunda district respectively. 
The workshop on SEMA mobile application in the MoW was conducted on 10th February, 2015. Participants included officials from the World Bank, Ministry of Water (rural and urban water supply departments, ICT department, and water resource management department), consultants who were involved in mapping the water points, and the SEMA research team. I was part of the SEMA research team and software developers who arranged the testing of the mobile application. A similar workshop in Bunda district was carried on 24th Feb, 2014. Participants included councillors from the wards of Mcharo, Kasahunga, Nyamuswa and Balili, District water technicians, DWE, COWSO representatives from the four villages, senior administrators, Information Technology experts, and representative from the Council Water and Sanitation Team (CWST).

\section{Figure 23: The location of four wards: Mcharo, Kasahunga, Nyamuswa and Balili}

(Source: Modified from Wesselink, et al., 2015)

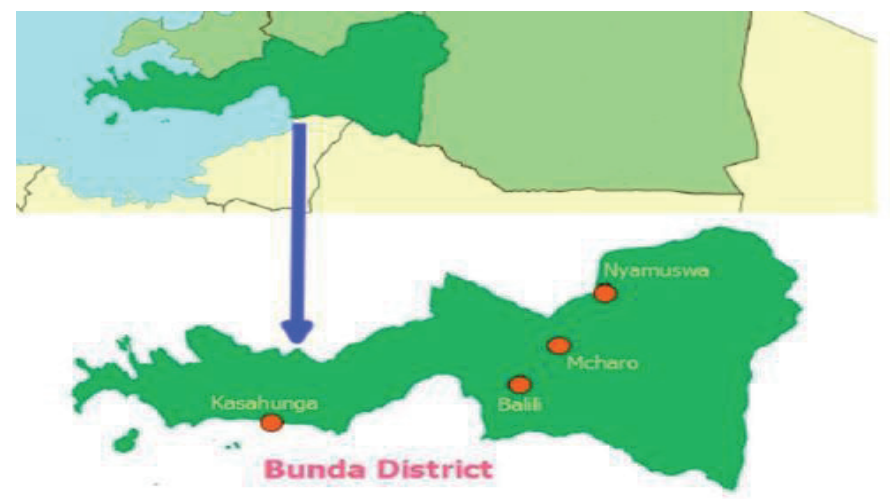

The workshop was organized into two sessions: the first session was about soliciting views from participants about the idea of reporting water status using a simple mobile phone; the second session sought to practically involve participants in reporting water point status using a mobile phone and observe their reactions as they report. The method used to collect the data for this chapter, including how the data were analysed is presented in chapter one.

\subsection{Findings}

The findings in this chapter show that both SEMA and the WPM system became entangled in much larger webs of influences: administrative level fights; interoperability demands of WB and IMF; inter-ministerial fights; and mentalities/technologies of communication between citizens and state institutions. In this case, I categories the findings into two classes: the first category relates to the $\mathrm{MoW}$ and the second on Bunda district. I present the findings in detail next.

\subsubsection{Internal bureaucratic politics and conflicts}

The internal bureaucratic conflict on the WPM involved three main actors in the MoW: officials in the department of rural water supply; officials in the department of ICT; and the consultant who was assigned to map the water points across the country. Officials in the two departments wanted the WPM system hosted in their respective departments. Originally the WPM system 
was designed and hosted in the rural water supply department. The rationality to host it there was that since the system deals with the management of data on rural water supply, it was logical to be managed by officials responsible for rural water supply. However, officials in the ICT department felt that the system was supposed to be hosted in their department because they have the ICT capacities and expertise needed to manage the system.

In 2011-2013 international donors issued money to the MoW to facilitate the mapping exercise. A consultant was hired to carry out the mapping work for the department of rural water supply. With a total of 40 staff - divided into three teams: one staff member from a consultant organization, one district official, and a person local to the area - and approximately 20 days of field work, the consultant was expected to map all water points in one local government authority.

However, upon submitting the mapping results, officials in the department of rural water supply noted that the consultant did not carry the work properly. For instance, they noted that $75 \%$ of the codes written onto the water points had already worn off due to exposure to the sun and rain thus removing the connection between the water point and the corresponding entry in the WPM system. In addition the officials said that the structure of the electronic forms that was used by the consultant to collect the water point mapping information was flawed thereby creating the possibility of errors. These observations created a tug of war between the officials in the rural water supply and the consultant. From this point the consultant blamed the rural water supply officials for lacking the ICT competence to understand how the work was done. In this case he reinforced the position of the ICT officials that the WPMS should be hosted in the department of ICT.

However, a senior respondent in the MoW explained that the politics behind the conflict, has to do with 'resource question'. He explained that "the ICT department, having been close with the consultant who was assigned to map the water points, had formed strong relations based on mutual material gains with big wigs in the ministry. Out of this mutually beneficial relationship the consultant was assured more work in the ministry even when he did not fulfil his contractual obligations for mapping the water points". Interviewed respondents in the department of rural water supply recalled the incidence when they applied pressure to the consultant to accurately map the water points and submit his report on time to the department, he inclined himself to the officials of the ICT department arguing a case that the project be shifted to that department. The ICT department also had its own interest in the project as it attracted a lot of funding from international donors (led by the World Bank) and the fact that the project had an IT component.

Another respondent also explained that, in the year 2014, the MoW organized a workshop in Arusha to discuss the consultant report on the water point mapping exercise. The workshop was attended by the Minister of Water, Permanent Secretary, Head of ICT Department, Head of Rural Water Supply Department, Coordinator Rural Water Supply, District Water Engineers, and donor representatives. The respondent recalls that the Minister of Water intervened on the conflict between the two departments and gave a directive that the WPM system should remain hosted in the department of rural water supply. The workshop participants blamed the consultants work on the mapping exercise on grounds of accuracy and reliability. Giving an example of labelling water points with a special pen that is not easily erasable, one of the respondent said that: "the consultant was given 12 USD as a unit cost for labelling each water point. The total number of water point was 74000 . In total, the consultant pocketed 888000 USD for this assignment. The pen used to label the water point was substandard resulting into loss 
of record of water points, the consultant should either repay the money to the ministry or relabel the water points at his own cost". Although the Minister gave a directive that the WPM system be hosted in the Rural Water Supply Department (RWSD), there are still silent conflicts between the two departments. The RWSD officials argue that the WPM data base was originally designed to address information challenges in the rural water sector. They see the ICT department as an organized cartel interested in material resources provided by donors for the WPM system.

\subsubsection{Interest in collecting information on new water projects}

The MoW is responsible for coordinating and monitoring the construction of new water projects across the country in rural areas. The projects are being financed by international donors, including the World Bank (WB), African Development Bank implementing(ADB), and the Netherlands Development Organization (SNV) to mention a few. This trend has motivated public officials to focus on the newly constructed water projects and pay little attention on the old water projects, which are in dilapidated shape and most of them are not functional. Coordinating and monitoring roles of the MoW are increasingly directed towards this new area of investment.

Reporting of functional and non-function water points in the WMP system is therefore more likely to focus on new water projects instead of old ones. Commenting on this trend during the SEMA workshop held at the MoW, a senior official in the ICT department opinionated: "We have to leverage the use of various innovations to ensure that Water Point Mapping system is dynamic. We are one family... we have to make sure we communicate what we do to others, and share rather than doing things separately... I like the updating mechanism of functionality developed by SEMA.... so that we remain with a big task of new water points. Our commitment to Open Data is to ensure that we cooperate and I will report the deliberations of these meetings to the state house'". Another respondent from the department of rural water supply pointed out that: "the focus on new water projects comes from the fact that they increase coverage of water supply services to community and are also supported by donors. The MoW does not have enough resources to renovate all old water projects in every rural parts of the country. This is the responsibility of COWSO's not us, the water policy is very clear on this. Our role as a MoW is to plan for new investments in collaboration with donors, coordinate and monitor to make sure that we increase rural water coverage".

The focus on new water projects raises a number of concerns with regard to the updating of the WPM system using the SEMA mobile application: first, excluding old water projects from information automation means that it becomes difficult to hold public officials to account for old water projects. Secondly, preferring a MIS that is focused to potentially support new water projects and side line the old ones clearly show strategies of extraversion i.e. new water projects are largely supported by donors who are pouring in huge sums of money through the Water Sector Development Programme (WSDP) in general and the Rural Water Sector Development Programme (RWSDP) in particular. This attracts a lot of interest from public officials with regards to new water projects.

\subsubsection{Willingness to accept the SEMA mobile phone reporting application}

Public officials in the MoW want to use the SEMA mobile application as a technical administrative tool for internal administrative operations, including demanding accountability from lower levels of governance. In this context they want the application to have a derivative 
role: one that reinforces the existing centralized administrative structures between central and local government through information. Thus from the point of view of formal rationalities and mentalities, public officials accepted the SEMA mobile reporting platform as handy and useful but with insistence that the updating of WPM system through mobile phones follow the formal bureaucratic procedures of reporting that are currently existing in the administrative set-up. A respondent at the MoW explained that "any new technology that seeks to help the MoW to do its work is welcome, but has to be in accordance with the ministry requirements and has to reflect service delivery regulations that are in the water policy of 2002 . The MoW has a role to make sure water coverage in rural areas is increasing and many people have access to water. If SEMA application can help the ministry to update on status of water points, it will help us to plan, budget and earmark new areas for investments". These remarks were echoed by another respondents who suggested that "the SEMA mobile application should help the MoW achieve its goals, including making sure that local governments are delivering water services to the people effectively in rural areas".

However, the views of public officials at the MoW run counter to the original rationalities and mentalities embedded in the SEMA application, which sought to empower lower level actors, including COWSOs to demand accountability from public officials, including the district and the MoW at large. Instead the MoW officials want to use the application for internal administrative operations, including monitoring the performance of local governments.

The emphasis on formal reporting procedures was echoed by World Bank officials during the workshop at the MoW organized to introduce the SEMA mobile application to senior officials of the MoW in terms of how it can be used to update the WPM system. The official commented that: the "MoW should use "API" to enable the WPM system communicate with other systems. The MoW should make all innovations around the WPM system talk to each other. API's are used by Face Book, Twitter, Whats App etc. It is an important tool to help us. Currently there has been a challenge on getting people who understand the current system i.e. WPM system. The MoW and the consultant should find a strategy on how to move forward on APIs ${ }^{30}$. The consultant should be in a position to inform the MoW on how to move forward..."

The World Bank and public officials in the MoW emphasis on formal R-M-Ts embedded in their view of technology present a different picture with what happens on the ground. For instance there were conflicts between departments of the ministry of water regarding the control of the WPM system. This clearly show different R-M-Ts by the public officials namely: the new technology that is being introduced is arguably a new potential source for obtaining resources privately i.e. strategies of extraversion but also a way of more centralization in the quest to monitor local governments.

\footnotetext{
${ }^{30}$ Application Programming Interface (API) is a set of routines, protocols and tools for building software and applications. An API may take the form of a web-based system, operating system of data base such as the WPM system which provides facilities to develop applications which can be integrated with the data base. The World Bank API is a data collection tool that collects social economic data from different parts of the world, including sub-Saharan Africa and make these data available to third parties. The data are used by development corporations for framing development aid and cooperation between the south and the north
} 


\subsubsection{Why digitised information would (not) change existing informal information practices}

Increasing efforts to formalize and digitise government communication internally and externally with other government agencies has not withered informal communication. The findings in this chapter show that, informal communication has remain dominant in government circles. There is a parallel world of politics in relation to information sending and receiving using mobile phones to update the WPM system, the real informal world existing in parallel with formal laws and procedures affecting accountability relationships. Informal connections determine what actions will be taken in regard to improvements in rural water supply.

Even at a time when new technologies are being introduced to digitize information flows from paper based to ICT, the informal parallel world of informality has continued to linger on. Information sent and received through informal channel is more likely to determine which actions will be taken in terms of improving service delivery in rural settings compared to that sent and received through formal channels. There are informal network of relationships in Bunda district between COWSOs representatives and district officials but also between district officials and the MoW. The relationships are grounded on clientelistic exchanges and mutual interests. For instance in case of a broken water point a member of COWSOs is more likely to call directly the district engineer when he/she has a personal relationship with him to solve the problem than to report the problem formally. Equally, the district Water Engineer is more likely to call the District Administrative Secretary at the regional level or a permanent secretary at the Ministry when he has a personal relationship with them to request a budget to finance water projects in his district than to follow the formal budgeting procedures which in the end take a long time to complete and even when completed money is not guaranteed to arrive in time.

Introducing a technology that mimics formal reporting channels in this context is side lined by a parallel world of informal communication. Respondents in the water department in Bunda district explained to me that they are more likely to respond to information coming from COWSOs if they happen to know the sender of the information informally than when they do not have any connection with the sender. Equally, respondents in the MoW in the department of RWS noted that informal connections with District Water Engineers (DWE) determine how fast they would respond to the queries raised by the DWE in regard to managing rural water supply than when they do not have such connections. Likewise, in the light of chapter six findings, informal institutions were found to be so powerful, competing in parallel with formal institutions.

In Bunda district, I found conflicting views on who should report information using the SEMA mobile application. Reporting information on functional and functional water point status is a power struggle issue, especially when the reporting of the information from the App is considered to change power relations regarding existing reporting practices as opposed to envisaged ones. On the one hand, COWSOs and councillors felt that the secretary general of a COWSO should report while on the other hand, the District water experts felt that the Village Executive Officers (VEO) should report.

The Village Executive office is recognized by the URT constitution of 1977 and the local government laws of 2000. From a legal perspective both entities are legit as they draw their mandate from robust legal institutions. The District water experts backed the Village Executive Officers (VEO) to assume the reporting functions because of the fact that VEOs provide important administrative link between the District officials and villages. VEOs are salaried 
officials, reporting is their basic responsibility. They are directly accountable to the DED and the DWE. Accordingly from the point of view of district officials VEOs should report. Relying on VEOs as main reporters would make things easier for the DWE because in reality most of the VEOs are ceremonial and very loyal to higher administrative ranks of the district. It is very easy to control them. A respondent explained that "the fact that VEOs are not political officials also makes them key allies of the district". However, some district officials were against the idea of using VEOs as reporters on grounds that VEO have a lot of administrative roles and responsibilities i.e. because the district lacks funds to employ new VEOs, most of the VEOs now working in the district are serving in acting capacities in the villages. They are not employed by the district hence not directly accountable to the district. In some villages VEOs were literally non-existent. The district did not have enough money to employ new VEOs.

On the other hand, the COWSO leaders supported the secretary general of the organization to report on grounds that: COWSOs are autonomous legal entities; they are supposed to be independent to manage water points on their own without interference from the district. Likewise the councillors echoed this position by arguing that the roles of COWSOs and the VEO and the district are very clear, i.e. COWSOs should send reports to VEO but should be able to report directly to the district. According to COWSOs views the main reporter should be the secretary general. This idea was challenged by the technical staff of the department of rural water supply on grounds that "technical staff make field visit to inspect water points and get paid. Shifting this responsibility to COWSOs means no incomes for themselves and their families"

The disagreements on who should report suggest that rationalities and mentalities embedded in mobile applications are not usually in agreement with local rationalities and mentalities regarding personalities or communities that should assume that role. SEMA sought to use COWSOs as the ideal reporters but district officials and even members of COWSOs think otherwise.

On the aspect of who should receive information through the SEMA mobile phone application, councillors felt that they should receive that information. However, district officials question the legitimacy/ rationality for them to receive information. Here the district officials, felt that SEMA mobile application is an internal technical tool designed as 'a working/administrative tool' for the DWE and technical people in the water department. Politicians including, councillors are therefore not part of this design. If they want information they can get it at the Ward Development Committees (WDC) where councillors serve as chairpersons of these committees. Hence they have access to all the information, including water point status information. Councillors insisted that they need information to be able to question the performance of the DWE in their respective wards.

The fact that district officials want to exclude councillors from receiving information from the SEMA mobile application raises concerns with regard to the role of data in mobile-phone driven accountability interventions. In the context of the actor-forum accountability framework councillors are the main account holders at the district level who are supposed to hold the administrative officials accountable, who are accountors. Theoretically, preventing councillors from accessing information from the new technology imply that councillors will not be able to scrutinize the actions and inactions of public officials. As a matter of fact, in practice, as noted in chapter five, informal institutions stands in a way to achieve accountability. 


\subsection{Discussion}

The findings in this chapter are categorized into two: the first category relates to the MoW and the second on Bunda District. On the first category I found that there are internal bureaucratic politics and conflicts in regard to the management of the WPM system connected to informal rationalities and mentalities of governance. This cold conflict has led the WPM system come to a silent halt. Although the WPM data has been made accessible through the website of the MoW and can be used for all kinds of analysis, the WPM is not being regularly updated by the District water Engineers (DWEs). Secondly, I found that, MoW officials are more interested in getting information on new water projects through the SEMA mobile application because new water projects attracts donor funding. As a result, this weakens accountability on old water projects. Thirdly, I found that MoW officials are willing to accept the SEMA mobile application to facilitate internal administrative operations of the Ministry, including demanding accountability from local governments and not vice versa. This practice is reinforced by centralization of the water sector, where local governments are treated as agents of central government and not autonomous entities.

On the second category, I found that there exist parallel world of politics in relation to information sending and receiving using mobile phones to update the WPM system, the real informal world existing in parallel with formal laws and procedures affecting accountability relationships. Informal connections determine what actions will be taken in regard to improvements in rural water supply. Secondly, regarding who should send information using the SEMA mobile application, the logical choice of COWSOs as reporters was contested, despite the formal requirement for them to report data on water supply. It appeared that the Village Executive Officers (VEOs), the lowest-level of government bureaucracy, feel bypassed by COWSO reporting, and they were supported in this by the district officials. The debate on who should report was based on two issues: the legal-administrative requirements and the actual practice on the ground. The district officials played their role as bureaucrats, quoting selectively from legal frameworks in order to exclude potential intruders (i.e. COWSO's reporters) from disturbances in the form of reports. For them, enlisting the VEOs would make things easier because VEOs are part of the bureaucracy and very loyal to higher administrative ranks of the district. Thirdly, on receiving information, it became apparent that the COWSO digital reports on water supply would be copied not only to the district officials and the MoW database but also to the elected councillors and civil society organizations that can then use the data to hold the district officials to account. The councillors welcome this idea, affirming that they need the correct data to be able to fulfil their oversight role. However, the district officials maintain that these are technical data that they need for the running of the schemes and that it is not appropriate for elected councillors to have access to the database.

The findings in this chapter indicate that the adoption of ICTs in the public sector in Tanzania and the MoW in particular is embedded in a formal reform rationality and mentality (expressed in the New Public Management and New Public Governance reforms) that conceive of informatisation of administrative procedures as a catalyst for rationalization, innovation and efficiency. These R-M-Ts of governance sought to transform the Weberian legal rational authority from hierarchical paper-based MIS to ICT driven MIS focused on achieving efficiency and effectiveness in the water sector. The WPM system is a key technology of such reform interventions. 
By automating internal office tasks through informatisation, new actors are created and new power relationships are constituted (Pelizza, 2015). Although this is considered by (OECD, 1998,2003 ) as a necessary remedy to reform bureaucracy in order to achieve efficiency gains and save public resources, the implications go beyond that. In the context of the WPM system it means an opportunity to obtain resources from donors through strategies of extraversion, which as a result conflicts between departments erupted as part of that struggle; it also means that rationalities and mentalities ascribed in the WMP system namely: informatisation of the rural water supply MIS for achieving efficiency and effectiveness in the water sector contradicts the locally understood rationalities and mentalities of managing information systems.

Notably, introducing technology in a new environment requires not only the capacity in terms of technical expertise and resources needed to manage the technology, social political factors, including locally understood rationalities and mentalities are key to its eventual success. Equally studies on ICT driven technologies suggest that when technology is introduced in a new context, it may either be transformative meaning that it can transform the existing order of relations among individuals and departments, including accountability relationships (Pelizza, 2015); or derivative i.e. maintaining the existing relationships i.e. mimicking the existing structures by focusing on the improvements rather than transformation (Georgiadou et al., 2011).

In this case, the WPM system has both derivative and transformative goals; it re-negotiates internal bureaucratic relationships, habits and unwritten rules. In the end, this poses challenges to the existing institutional order as a whole, and triggers new forms of authority and procedures of legitimacy (Pelizza, 2015). Although there is a proposition that this state of affairs calls for the rethinking of framing of ICT development from 'eGovernment' to 'iGovernment' (MayerSchönberger and Lazer, 2007) where in the latter case the analysis of 'hard' digitization technology is complemented with 'soft' consideration of information flows and actors and administrative procedures are supposed to become more fluid, faster and taking fewer inbetween steps, with some steps being automated, still locally ingrained ways of governance have to be captured and accommodated in the design of any technological endeavour that is potentially derivative and transformative.

There are various competing R-M-Ts around the WPM system. On the one hand the WB and other international donors are advocating digitisation to foster new emerging governance models focused on data-driven development. Here, the trend on digitisation is to influence the way Low and Middle Income Countries (LMIC) are made legible, including the implications for power dynamics amongst development actors (Taylor, 2015; Taylor and Broeders, 2015). For instance the WB emphasis on API explains this trend.

Currently the World Bank API exposes a variety of data for approximately 200 countries for more than fifty years (https://www.phase2technology.com/blog/world-bank-open-api-2-0launched/). Castella, (1996) has termed this phenomenon 'information capitalism'. On the other hand, local public officials acknowledge in a context of formal RMTs that digitisation through ICTs and mobile phone applications is handy and useful but in the context of informal RMTs these applications are turned into opportunities for extraversion strategies. The internal conflicts in regard to the management of the WPMS between departments in the MoW, including the financial resources that are provided by the WB and other international donors highlight this picture. 
Rottenburg's ethnographic case study, conducted between 1992 and 1998, on the organizational and technological improvement of the waterworks of three cities in Tanzania (Arusha, Moshi and Tanga) is revealing with regard to these opposing R-M-Ts. Rotternburg explains how the project was financed by the German Development Bank (KfW) and the relationships between the bank as a donor and manager of development aid and events as they unfolded between Tanzania, Germany and other sites as the water system was being managed.

While paying special attention to technologies of inscription and representation, focusing on mapping and building data bases, he argues that 'development cooperation is about the transfer of resources from the rich countries of the north to the poor countries of the south. In order to be legitimate within the rich countries, this transfer has to be made in ways that can be accounted for and must appear predictable. In order to secure this accountability and predictability, the resources - money, technology and know-how - cannot simply be handed over as means to achieve ends that are to be defined autonomously by the recipients. The means are rather linked to certain ways of doing things and have certain ends inscribed in them before they are transferred. This runs head-on against the other main political goal, namely to facilitate self-determined and sustainable development'. However, as argued by (Kersall, 2008; Hyden, 2006) sustainable development largely depend on locally understood governance practices.

At the moment the WPM database is not being updated regularly. It is not therefore being used to inform policy outcomes. It may also be argued that apparently no one is being held to account in regard to data currently displayed in the WPM database. There are also questions in regard to the accuracy and reliability of the data currently displayed on the WPM website (Vernplanke and Georgiadou, 2016 unpublished paper). The data inaccuracy and unreliability in the WPM stems from five potential categories of errors: changes over time; syntax errors; missing data and ambiguous values; subjective observations; duplication of records and the definition of functionality of water points (ibid).

The data errors observed in the WPMS raises significant questions in regard to emerging accountability interventions that rely on data from ICT's technologies. For instance, how can public officials be held to account when the available data is unreliable and largely flawed? Or to put it otherwise how can the rural water sector be improved based on data that misrepresent the actual status of the water points in rural settings. Relatedly, it raises an alarm on whether responsible organisations in the international donor community count what counts (Nganyanyuka et al., 2014). Thus the WPM data base can be viewed as an opportunity for strategies of extraversion by local public officials because it attracts resources from international donors. The question of whether the data is reliable and accurate for various interventions in the rural water sector becomes a secondary one.

The updating of the WPMS through the use of mobile phones is currently in the pilot testing in Bunda District. However, preliminary round of testing already show that there exist parallel world of politics in relation to information sending and receiving between COWSOs and district officials with the real informal world existing in parallel with formal laws and procedures affecting accountability relationships. Informal connections determine which reports will be received by the district officials and which actions will be taken to improve the functionality of water points. 


\subsection{Conclusion}

This chapter has sought to investigate the role of data in ICT/Mobile phone accountabilitydriven interventions in the water sector in Tanzania. The chapter made use of the WPM system and the SEMA mobile application cases to analyse this new potential accountability venture in the water service delivery spectrum. The findings indicate that both the SEMA and the WPM system were met with challenges that can be attributed to local governance practices. The two projects became entangled in much larger webs of influences: administrative level fights; interoperability demands of WB and IMF; inter-ministerial fights; and mentalities/technologies of communication between citizens and state institutions. I argued that this 'entanglement' is a result of relatively opposing governmentalities: one informed by formal R-M-Ts of governance, which is favoured by donors and national government officials; and informal R-M-T's ingrained in the daily undertakings of local government and national government officials (Table 20).

Table 20: Summary of conflicting governmentalities on ICT-induced accountability interventions

\begin{tabular}{|c|c|c|}
\hline 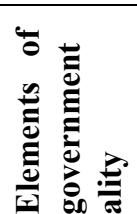 & $\begin{array}{l}\text { National and local government } \\
\text { officials }\end{array}$ & International donors \\
\hline $\mathbf{R}$ & $\begin{array}{l}\text { Thinking about ICTs and mobile } \\
\text { telephone- induced accountability } \\
\text { interventions is based on the } \\
\text { fusion between NPM reforms and } \\
\text { traditional governance practices. } \\
\text { The former is inspired by post- } \\
\text { colonial R-M-Ts while the latter is } \\
\text { inspired by the pre-colonial and } \\
\text { colonial ones. } \\
\text { The key to accountability is } \\
\text { informal networks }\end{array}$ & $\begin{array}{l}\text { Thinking about ICTs and mobile telephone- } \\
\text { induced accountability interventions is based on } \\
\text { the NPM reforms inspired by the Principal- } \\
\text { Agent theory and Collective-Action theories } \\
\text { The key to accountability is to digitise } \\
\text { government operations from paper-based MIS to } \\
\text { ICT-based MIS } \\
\text { ICT-based MIS = information = transparency + } \\
\text { accountability }\end{array}$ \\
\hline $\mathbf{M}$ & $\begin{array}{l}\text { A belief on informal and formal } \\
\text { channels of communication } \\
\text { A belief that ICTs and mobile } \\
\text { telephone should maintain } \\
\text { existing patron-client exchanges } \\
\text { A belief that ICTs and mobile } \\
\text { telephone are derivative, i.e. } \\
\text { improving existing internal } \\
\text { workings of the MoW and } \\
\text { Bunda District }\end{array}$ & $\begin{array}{l}\text { A belief on formal channels of communication } \\
\text { A belief that ICTs and mobile phones will } \\
\text { transform cleintelistic exchanges and prevent } \\
\text { corruption } \\
\text { A belief that ICTs and mobile telephone are } \\
\text { derivative and transformative at the same } \\
\text { time, } \\
\text { i.e. improving existing internal government } \\
\text { operations as well as transforming them }\end{array}$ \\
\hline
\end{tabular}




\begin{tabular}{|l|l|l|}
\hline T & $\begin{array}{l}\text { Rewards: } \\
\text { ICTs infrastructures turned into } \\
\text { opportunities for 'strategies of } \\
\text { extraversion' }\end{array}$ & $\begin{array}{l}\text { Rewards: } \\
\text { ICTs infrastructures for digitising MIS in the rural } \\
\text { water sector, e.g. the WPM system }\end{array}$ \\
$\begin{array}{l}\text { Punishments: } \\
\begin{array}{l}\text { Exclusion from the informal } \\
\text { networks which provide } \\
\text { opportunities for extraversion } \\
\text { strategies }\end{array}\end{array}$ & $\begin{array}{l}\text { Punishments: } \\
\text { Cutting development aid in the rural water sector }\end{array}$ \\
\hline
\end{tabular}

The national government officials, however, subscribe to donors R-M-Ts for strategies of extraversion. Thus as noted by (Wesselink et al., 2015), in the context of Science and Technology Studies, any piece of technology is part and parcel of a social context, both emerging out of that context, impacting upon it, and gradually acquiring new, frequently unintended meanings through anticipated and unanticipated use. In other words, context counts, implying that multiple contexts count, and time counts as well. 


\section{Conclusion: going with the grain or against the grain}

In this thesis, I sought to systematically and empirically answer the broad research question regarding how public officials are held to account in Tanzania in the context of water service delivery. In answering the research question, I analysed four levels of governance in relation to accountability practices: national, trans-national, regional and local governments. I also examined the potential of enlisting the ICT/ mobile phone accountability-driven initiatives at the national and local levels in the water sector. The objective of this thesis, therefore, was to empirically interrogate accountability practices at various levels of governance in the water sector in Tanzania. In this final chapter therefore, I would like to present my concluding remarks by answering the main and specific research questions. However, I begin by revisiting the governmentality approach, providing reflections on the evolution of this research.

\subsection{The governmentality approach revisited}

Proponents of the governmentality approach (with a liberal inclination) claim that the governmentality approach cannot have analytical purchase in analysing African cases because governmentality is essentially a western-European concept. So the question in this case is: was it doable and useful to apply the governmentality concept in the context of my dissertation, i.e. Tanzania? The answer is a qualified and cautious 'yes'. This assessment is largely reflected in the evolution of the research process itself as well as the findings.

The initial framing of this thesis was two-fold: firstly, as I prepared to go to the field in Tanzania, I intended to use Principal-Agent theory as my major theoretical framework. As I explored my empirical material extensively, I hit upon the notion of corruption. Most respondents I spoke to framed water supply problems as essentially connected to corruption as predominant among other problems. This discovery led me to do a co-occurrence textual analysis (using Leximancer) of official government documents, statements and publications by CSOs, newspapers and transcribed interviews of the citizens in Dar es Salaam and Bunda district to investigate how authorities (politicians and public officials) and non-authorities (citizens and NGOs) frame the problem of water services (Katomero et al., 2013). The outcome of these analyses confirmed that corruption was indeed a master frame or a lens through which all different groups in society look at the basic problems in Tanzania. However, authorities and non-authorities differed in their 'readings' of corruption: authorities considered it as a 'solvable problem' through institutional reforms (i.e. P-A and/or collective action inspired reforms), whereas non-authorities experienced corruption as 'destiny' or a 'way of life' from which there was no escape.

Only then gradually emerged the intuition of looking at corruption as a form of governmentality. This framing was triggered by a quote from Nigerian Blogger, Ayo Songuro who elucidated in his famous blog post that:

“...Nigerians are corrupt, they say. I am a Nigerian and I know why I am corrupt. I am corrupt because I am hungry. Because I need the food, the whole food and nothing but the food. Because I have to "hustle" if I want to see the food. Because without food I am useless, to myself and to society. A hungry man has no principles; morality is a luxury affordable to the well fed. I am corrupt because my hustle for food is filled with obstacles, because I cannot work as a labourer without tipping the foreman, because I cannot work in the civil service without greasing the wheels, because I cannot work in 
the private sector without "knowing" someone, because I cannot get a contract without contributing to the network. I am corrupt because I am hungry. I am corrupt because nobody knows tomorrow. I am corrupt because my society has no welfare plan and the pension scheme is unreliable. Yet a portion of my salary has to go to the pension scheme, tax and whatever else the government decides..." http://ayosogunro.com/2014/06/11/why-i-am-corrupt-in-defense-of-nigerians-by-ayosogunro/.

The quote illuminates the idea of governmentality in its societal embeddedness with regards to corruption, because this is indeed the way people look at corruption. My findings clearly showed that corruption was perceived as 'master problem frame' by authorities and nonauthorities above all other causes of policy failure. Different frames, rationalities, mentalities and technologies have intertwined so as to become a governmentality, where a significant part of the formal and informal dynamics is manifested in corrupt practices. As a result, authorities in the water sector use a discourse of formal institutional reforms which allows them to acknowledge corruption as a problem and reap its fruits at the same time (Katomero et al., 2014). With such hegemonic framing of corruption as a formal institutional problem requiring formal accountability solutions, non-authorities are - by default or design - kept out of, or at most at the margins of, the official anti-corruption programmes. Recognizing that there is no escape route out of the corrupt system no matter the formal institutional context - at the same time realizing that they are complicit in its maintenance and continuation -non-authorities are left with few options apart from hidden forms of resistance (Scott, 1990).

As a consequence, the practices of citizens and non-authorities ('hustling for water') consist of petty corruption and tactics of hidden resistance; they lead lives of corruption as 'losers', as 'destiny' or inescapable 'way of life'. On the other hand, the practices of authorities are limited oversight in exchange for bribes as a means to reap the benefits. The parallel practices of donors with their good governance anti-corruption programmes, jointly reproduce and maintain this governmentality to the advantage of authorities.

Next came the problem for me to re-conceptualize accountability practices as governmentalities, essentially by the distinction between formal and informal accountabilities. The re-conceptualisation of accountability practices as governmentalities was triggered by analytic weaknesses embedded in the PA and Collective Action (CA) frameworks for analysing accountability. PA and CA frameworks have tended to focus on accountability practices in formal contexts, leaving the informal world of accountability practices unexplored. Thus, the governmentality approach was useful in this thesis because it provided a richer analytic purchase than the PA and CA frameworks for analysing accountability as a socially embedded practice interwoven with the fabric of society-government relations. In addition, the approach was very useful in analysing political power, including interactive dynamics between formal and informal accountability practices beyond the formal settings.

\subsection{Answers to specific research questions}

The results presented in this thesis have indicated that accountability practices at the national and local government levels in the water sector are informed by an interplay of different and often conflicting governmentalities. This gives rise to complex and self-contradictory drivers, the result of which is that formal accountability reforms proposed by international donors are difficult to implement and even lead to counterproductive results. Thus, holding public officials 
at national and local government levels to account cannot be understood in donor-driven principal-agent and collective-action approaches which do not capture all the involved governmentalities and their interactions. Instead, accountability practices in the water sector should be understood as governmentality where conflicting rationalities, mentalities and technologies are intertwined. This situation gives room to national and local government officials to accept donor-driven accountability reforms as an incentive to obtain resources through strategies of extraversion for personal benefits as well as for political objectives such as clientelistic politics. In practice, the locally understood governmentalities compete with the donor-driven formal accountability governmentalities (Table 22). 


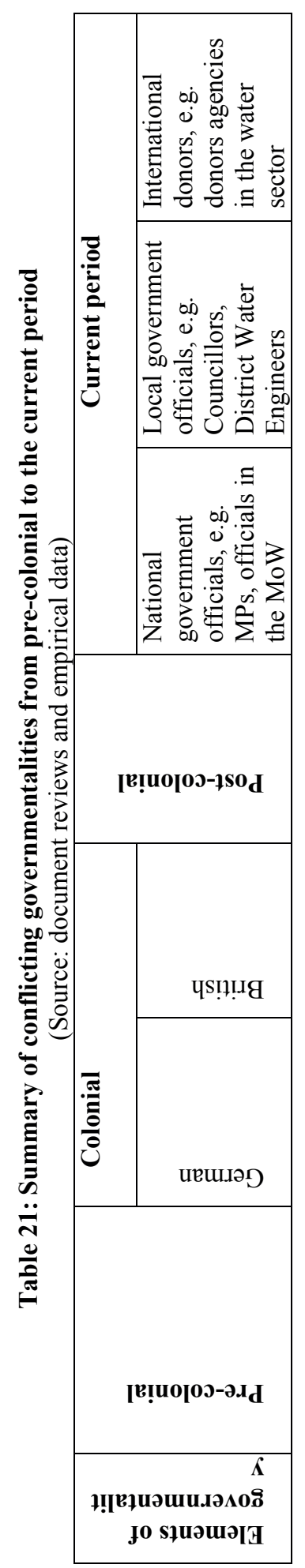

守 


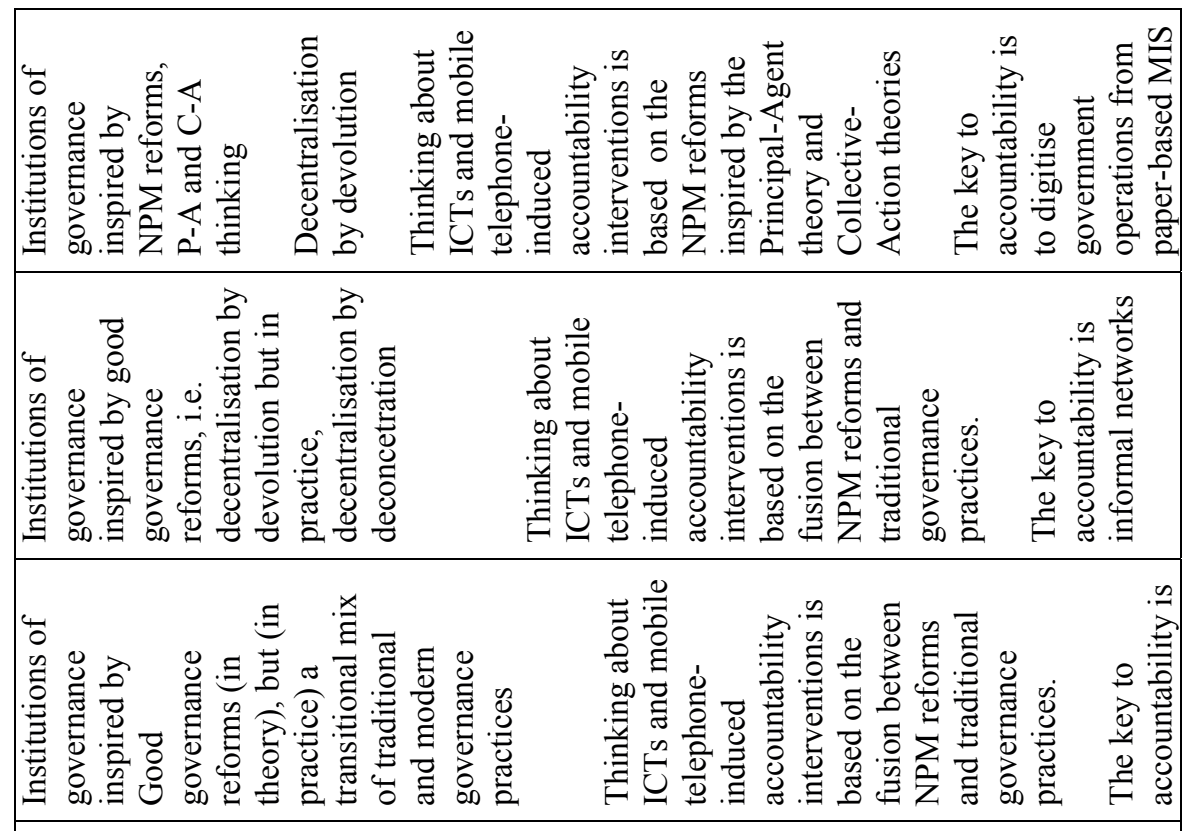

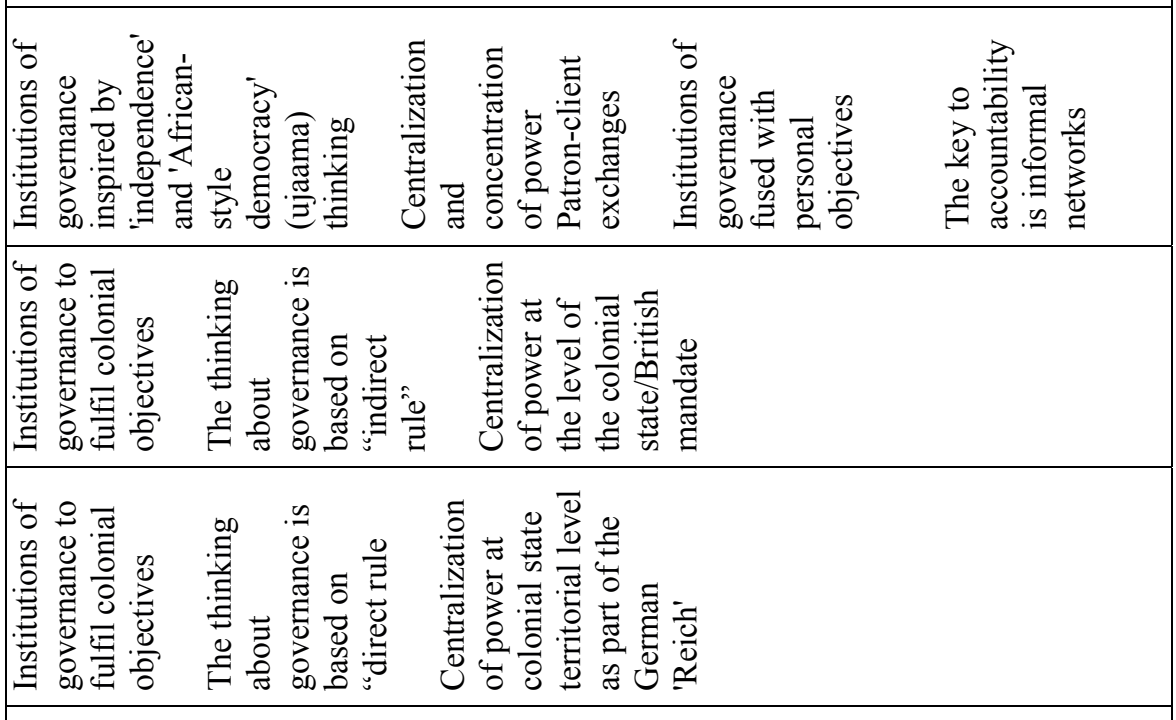

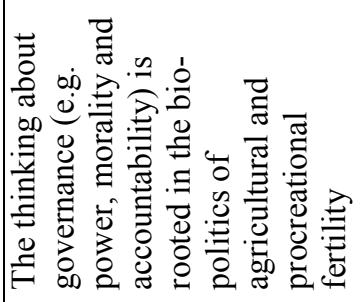




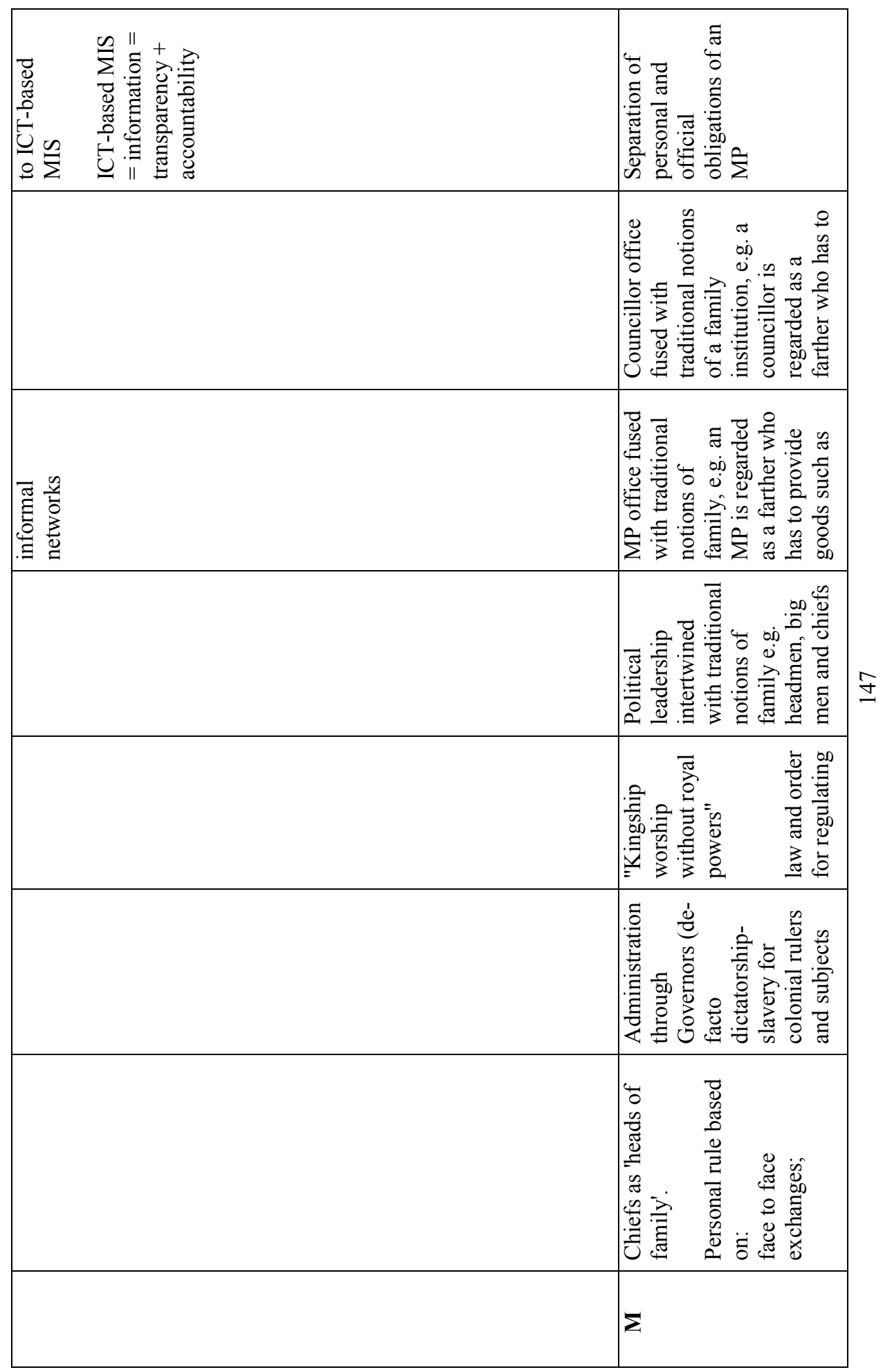




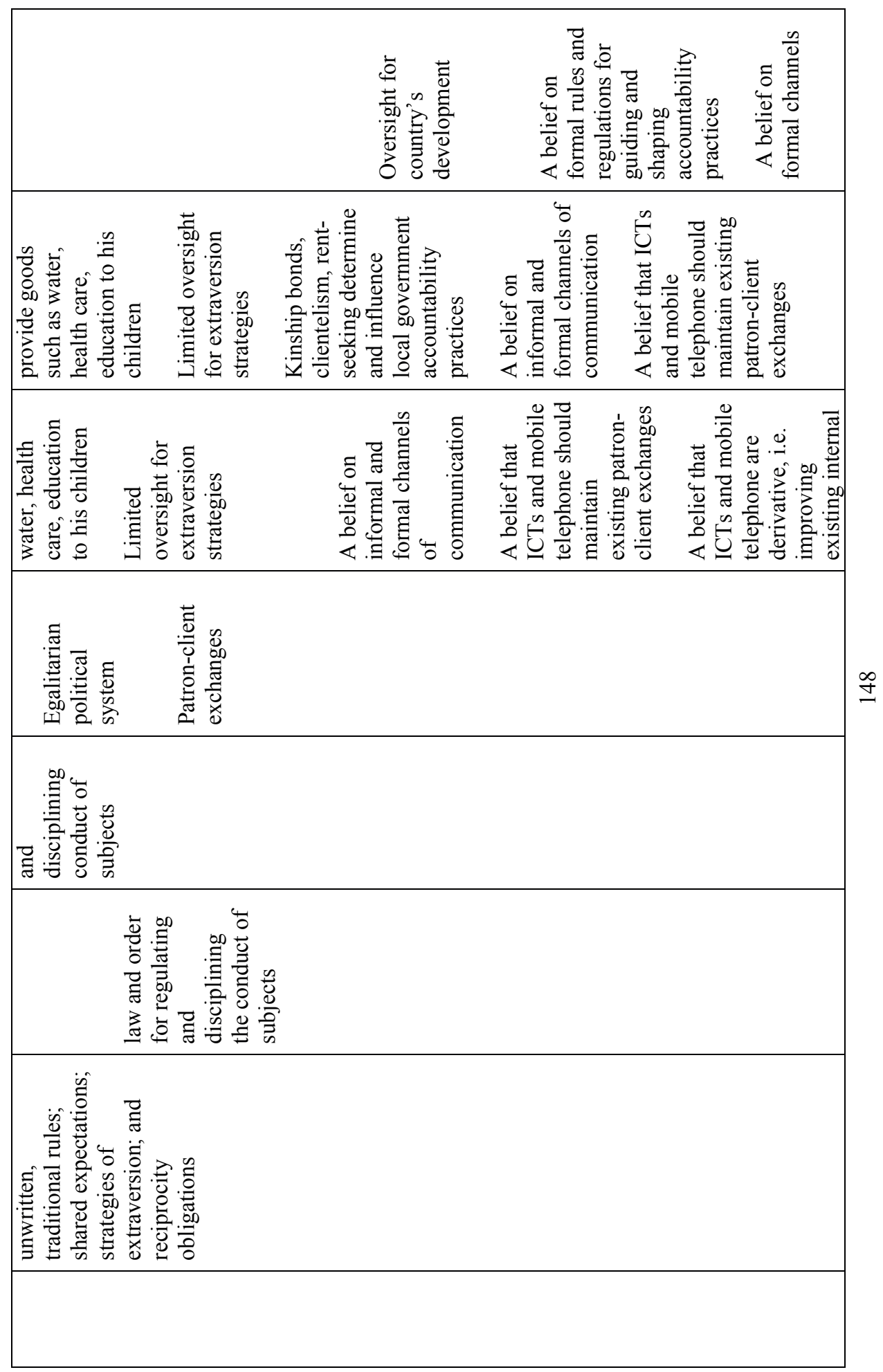




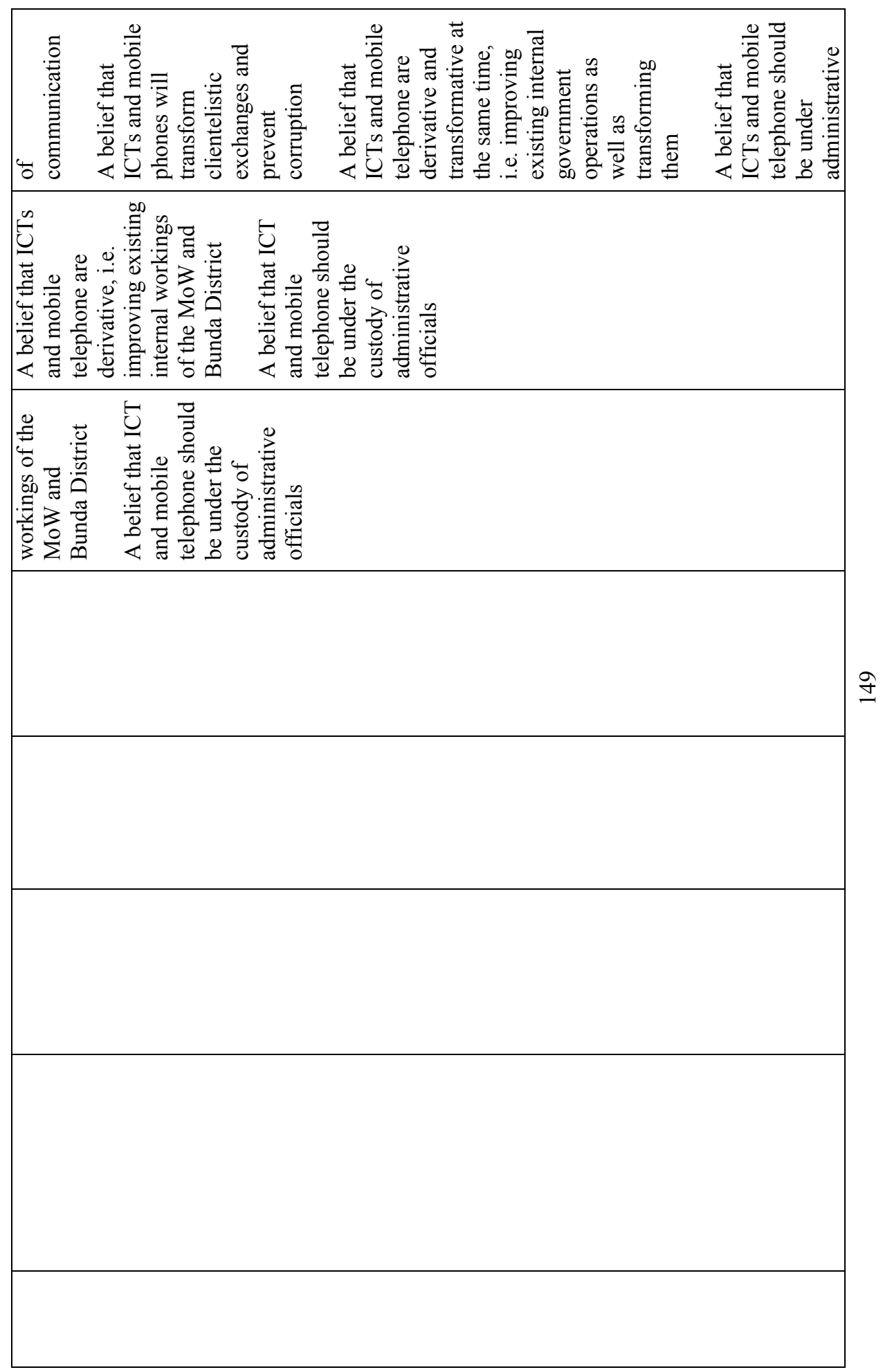




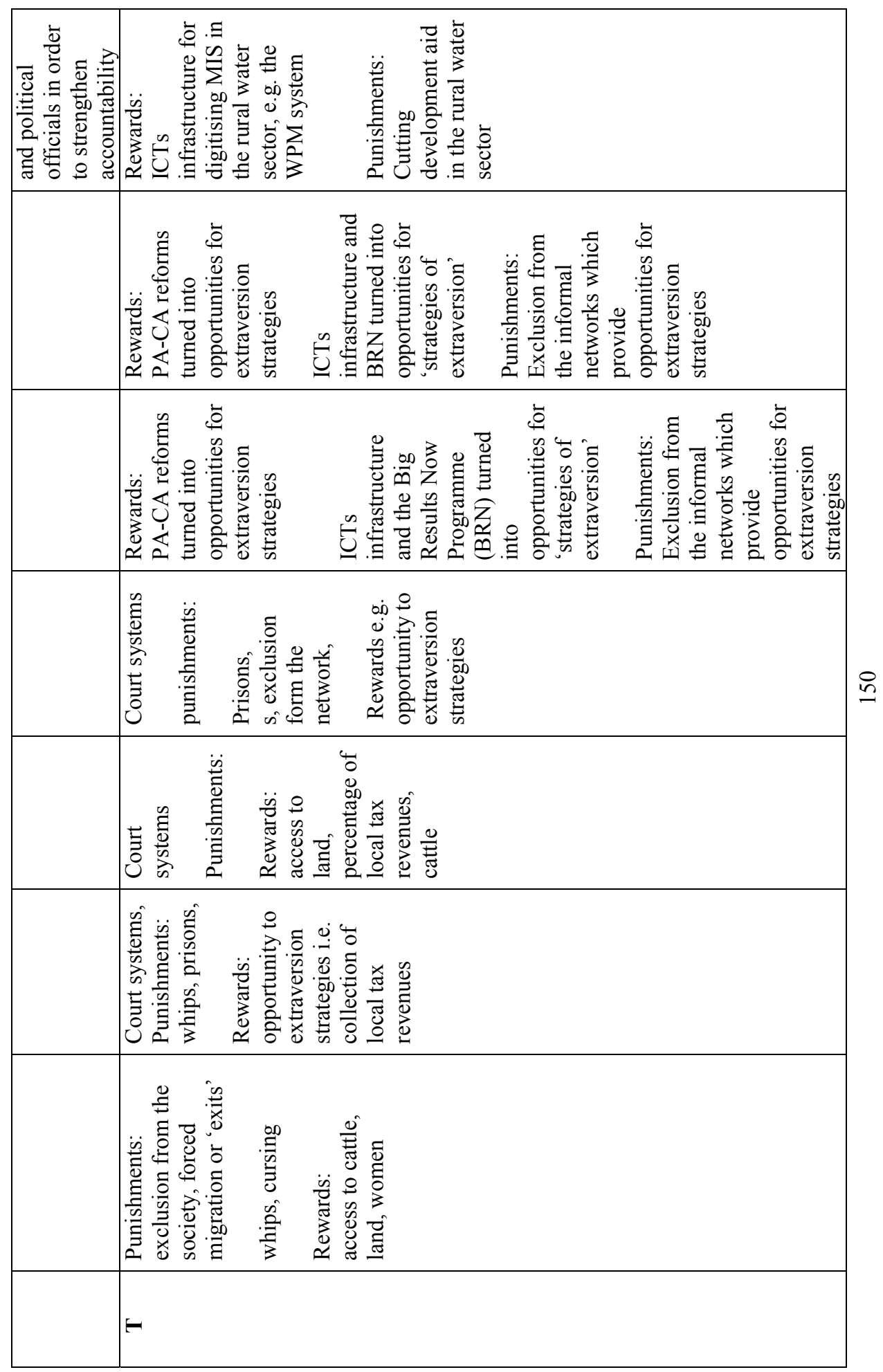




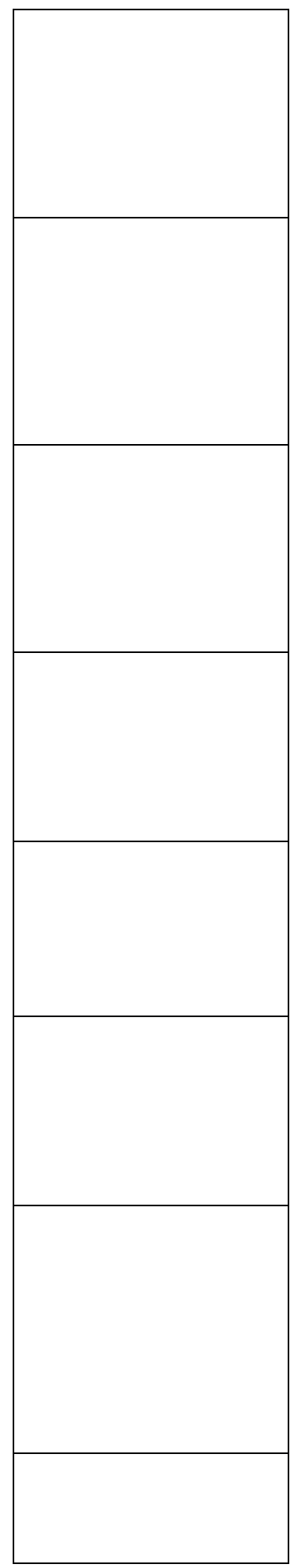

5 
To understand the current situation, it is imperative to consider how present accountability practices in the water sector in Tanzania have their roots in the historical governmentalities of pre-colonial, colonial, and post-independence periods. The thinking about governance (e.g. power, morality and accountability) during pre-colonial period was based in the bio-politics of agricultural and pro-creational fertility. These ideas, in turn, created a social fabric that informed the governance practices between African decision-makers on the one hand, and the rest of the society on the other. Although colonialism transformed this social fabric by introducing new ways of governance informed by colonial R-M-Ts (summarised in Table 20), it did not destroy completely the pre-colonial R-M-Ts. As a result, after independence the precolonial R-M-Ts of governing re-emerged and became part of the political process at the national and local government levels, as they are to date. The consequence is that public officials, at all levels of government, practice (internal-domestic or external-transnational) extraversion games, all the while advocating for PA or collective action (CA) inspired reforms; which allows them to be the winning part of a corrupt system and yet, with some credibility, say they are abolishing it, at least intentionally. The rest of the people in Tanzania lives corruption as 'losers', as 'destiny' or inescapable 'way of life'. At the same time, donors advocating PA or CA-inspired reforms, by default or by design, in fact keep this system running. Only by quitting their roles do they in fact help abolish a perverse system and give citizens of Tanzania a chance to truly hold their government accountable.

Besides the overall research question answered above, this study had four specific research questions as follows:

How do MPs think of their own role of exacting accountability from the executive?

The first research question sought to investigate how MPs think of their own role of exacting accountability from the executive. The conclusion is that parliamentary accountability in Tanzania is hampered by four discourses held by Members of Parliament which enable the executive to rule in semi-autocratic ways. These discourses indicate separate mentalities, which makes it difficult for unidirectional-tailored accountability reforms to strengthen parliamentary accountability. For instance, while donors believe parliamentary accountability can be strengthened by increasing resources (in the form of development aid) to the executive for addressing development challenges, the existing mentality amongst MPs is that of exercising limited oversight to the executive to obtain resources for themselves and their electorate. Thus, executives and MPs collude to obtain resources from donors for strategies of extraversion. This practice is reinforced by the fact that the office of an MP is infused with traditional notions of family, i.e. an MP regarded by the electorate as a farther who has to meet their social and physiological needs no matter where and how he/she obtain the resources. The second conclusion is that even if opposition parties obtained a parliamentary majority, the governmentalities present in the discourses of Tanzanian MPs would prevent the achievement of greater democratic accountability.

Can the councillors hold the executive (public officials) at the local level to account? If yes, how? If not, why not?

The second specific research was whether the councillors in Bunda district can hold the executive (public officials) at the local government level to account, and whether yes or no, how the findings could be explained. The conclusion is that the councillors cannot hold the executives to account because the accountability practices, in the context of rural water supply, show that the R-M-Ts inscribed in the informal accountability are competing with formal ones. The result of this is that both administrative and political officials' behaviour goes against the 
formal rules of the game. The councillor's oversight role over the executives is thereby principally determined by informal accountability practices. These determine to a large extent which actions are taken in dealing with the rural water sector. Specifically, mentalities such as kinship bonds, patron-client practices, rent seeking, and clientelism are infused into the governance routines of councillors and local executives and determine local accountability practices. Thus, donor reform programmes that are oblivious of this governmentality create opportunities for strategies of extraversion and corruption.

Will ICT/mobile phone-induced accountability interventions be accepted by public officials in the MoW and local authorities as part of their Management Information Systems?

The third specific research question was whether ICT/mobile phone driven accountability interventions would be accepted by public officials in the MoW and local authorities as part of the information they use to make decisions, and especially as part of their Management Information Systems. I used two interrelated cases to answer this question: the Water Point Mapping (WPM) system and the SEMA mobile phone application. My conclusion is that although in principle public officials accept ICT/mobile phone accountability interventions in the water sector as part of the MIS, in practice informal R-M-Ts of governing hampers their willingness to accept the technology. This resulted in some resistance to both the WPM system and the SEMA app. These two ICT-driven accountability initiatives thereby became entangled in much larger webs of influences. One is informed by formal governmentality which is largely favoured by donors and national government officials; and an informal one ingrained in the daily undertakings of national government and local government officials.

What is the role of international donors in accountability practices in the context of water supply in Tanzania?

The fourth research question concerned the role of international donors (multilateral and bilateral) in accountability in the context of water supply in Tanzania. The role of donors is clearly visible in both financial and technical support of water projects, which can be observed through concomitant bilateral and multilateral funding programmes such as the water sector development programmes in general and the rural water supply development programme in particular. Since the elements needed to answer this question have not yet been presented together in one place, I will elaborate on this specific research question a little more than on the previous ones.

At the national level, donors exert considerable influence on the executive. As noted by Hoffman (2006), in Tanzania donors negotiate their programs with the president and senior ministers, not with parliament. This situation side-lines MPs from approving or disapproving policies proposed by donors. Centralizing decisions in the executive branch thus permits donors to design their programs outside of public view, permitting them to appear not to exercise significant influence in the country's domestic politics while in fact they do (ibid). The fact that the executive branch is intertwined with the donors makes it possible for national government officials to engage in strategies of extraversion to obtain resources. In addition, this limits members of parliament's oversight role over the executive by creating a situation where the executive can use the abundant resources supplied by donors for political clientelism, including distributing goods and services to MPs to win their support. This also creates opportunities for MPs to perform limited oversight over the executive for extraversion strategies to obtain resources for their constituencies. 
At the international level donors can be understood as actors in the adoption of New Public Management policies through international transfer. In this context actors (both national and international) engage in a process of searching and acquiring ideas and knowledge from different policy environments in a bid to address problems afflicting them. The process of searching and learning is usually confined within a specific formal policy space, i.e. it is informed by a governmentality that assumes that members abide to the rules. Whether the act of subscribing to such a regime is voluntary or involuntary is not a key point of discussion here. It may suffice to posit that in international policy transfer the role of donors manifests in two ways: one involves the traditional western donors who transfer knowledge and resources in bilateral and multilateral arrangements to developing countries in the name of development aid; the second involves south-south development cooperation, where countries of the south engage in a process of learning from each other's development models in order to adopt, copy or emulate. A notable example here is the Big Results Now (BRN) Programme described in chapter six (sect.6.3). In the first case, the transfer manifests as a drive for public service reforms where recipient countries, including Tanzania, are increasingly called upon by international donors to embrace the 'good governance' doctrine as a precondition for aid. This call is largely informed by the New Public Management (NPM) and New Public Governance (NPG) thinking. Both the NPM and NPG paradigms advocate private sector principles in running government activities with the goal of achieving efficiency and effectiveness in public service delivery. In the second case, the influence of donors manifests through designing and financing water sector projects. According to Janus and Keijzer, (2015), this has led to an increased emphasis on results, value for money, including the effective use of taxpayer's money.

Establishing proof of the achievement of results is high on the domestic political agendas of countries that provide aid as well as those that receive aid. Donors who provide development aid to developing countries are increasingly held accountable by their respective national governments to make sure that aid is used optimally for intended objectives by the recipient countries. The NMP reforms are a way to ensure this accountability. Result-based approaches are increasingly designed to disburse development funds only once pre-agreed results (which are quantifiable, achievable in incremental steps and verified regularly and independently) have been reached by the recipient country (Janus and Keijzer 2015:1). In this way, value for money is potentially attained.

Thus, through the international dimension, the role of donors in the water sector is manifested principally in the support for the construction of new water facilities as well as in technical documents formulated to guide projects in the provision of public services. As noted in chapter six, international donors have exerted considerable influence in rural areas of Tanzania for decades, through the construction of facilities but also the establishment of local maintenance arrangements often at arms-length of the government bureaucracy. With the funding of these projects the rationalities and technologies for implementing the projects are also imported. However, the focus on new water projects neglects the issue of maintenance and repair of these facilities, which are supposed to be done either by COWSOs or by the government.

The focus on new water projects has reinforced strategies of extraversion among councillors and the executives. New water projects are heavily funded by donors. District officials, through the central government have access to these resources. The district executive officials use the resources to silence left winged councillors from exerting accountability from them. As a result, councillors are reduced to rent seekers chasing rents to provide tangible benefits to their electorates in order to be re-elected and in the end comprise their oversight roles when elected. 
The role of international donors is also visible through the ICT/mobile phone-induced accountability interventions seeking to strengthen accountability in the water sector. Here, the donor's role results in various competing governmentalities around the ICT/mobile phoneinduced accountability interventions. For instance, the World Bank (WB) and other international donors are advocating digitisation to foster new emerging governance models focused on data-driven development. Here, the trend on digitisation is to influence the way Low and Middle Income Countries (LMIC) are made legible, including the implications for power dynamics amongst development actors (Taylor, 2015; Taylor and Broeders, 2015). For instance, the WB emphasis on API helps to explain this trend. Currently the World Bank API exposes a variety of data for approximately 200 countries for more than fifty years (https://www.phase2technology.com/blog/world-bank-open-api-2-0-launched/). Castella, (1996) has termed this phenomenon 'information capitalism'. While local public officials acknowledge that digitisation through ICTs and mobile phone applications is handy and useful but these innovations are turned into opportunities for extraversion strategies. The internal conflicts in regard to the management of the WPMS between departments in the MoW, including the financial resources that are provided by the WB and other international donors, confirms this picture.

Based on the foregoing, the relationship between donors and public officials in the water sector through bilateral and multilateral aid programmes can only be developmental if it lays the foundation for its future rejection, i.e. if it can be used in a manner that promises eventual selfreliance. In the water sector both donors and public officials subscribe (at least in theory) to this view, as none of them would publicly support an aid relationship that nurtures perpetual dependency. In practice, however, there are a few well-intentioned donors who would give aid for altruistic purposes, in the belief that the water sector needs robust interventions to improve water supply. However, the majority of donors in the water sector are self-interested individuals and organisations. As a result, aid provided in the water sector is used to strengthen a dependency relationship between the donors and public officials. This situation breeds strategies of extraversion among public officials for resources are always available in the form of money provided by donors in the water sector. Thus, the conclusion is that the continued emphasis by donors on PA- and CA-induced accountability reforms will not yield any meaningful results. The international donors' experimentation with the HESAWA projects in the lake zone, including Bunda district, presented in chapter six, the BRN programme, WPM system and many others should have provided good reason to argue that interventions which are not informed by the understanding of the governmentalities of public officials are not always very effective. But, as pointed out by Goran Hyden (2010), international donors prefer a legally defined public mandate because it is more manageable. An intervention in a specific 'formal' space is more feasible because there is less risk that donors will be accused of interference in domestic politics (Hyden, 2010:3)

\subsection{Exploring governmentality in Africa deeper and wider}

I have investigated the accountability landscape in Tanzania looking at various governmentalities that influence international donors', national and local government officials' accountability practices. However, it is important to note that my account of this governmentality is limited to the cases that I selected. Notably, there may be other cases and other interesting areas of research that may open up deeper and wider lines of inquiry. Here, I briefly present five research areas that I consider interesting. 


\section{A governmentality involving citizens and Non-Governmental Organisations}

Non-Governmental Organisations in Africa play a role in the area of public service delivery. To an extent, they complement the government in providing health care, water and education services. In addition to the service delivery functions, NGOs also champion the course of democracy by advocating for democratic reforms, educating citizens on their rights and obligations, as well as demanding accountability from public officials. Thus, the role of NGOs in the area of public service delivery has shifted from a passive object of government to be acted upon into an entity that is both an object and a subject of government. Although this work tried to unravel framings of citizens and NGOs with regards to water problems during the early stages of the research process, a specific focus on governmentalities involving large samples of citizens and Non-Governmental Organizations would be a useful piece of research, which could shed more light on citizens-NGOs governmentalities in Africa.

\section{Governmentalities in other sectoral case studies, for example the health sector}

The focus of this study was limited to the water sector, i.e. the individuals, institutions and organisations found in the water sector in Tanzania. However, compared to the health sector, it is well known that the water sector in Tanzania is not well organised. It is messy and indeed confusing. Part of this confusion is manifest in the various meanings ascribed to the concept of water as well as in various institutional designs for its provision. For instance, in Tanzania water is a public good, private good and at the same time a common pool resource. In essence these various meanings would require different institutional designs for the provision of water. The health sector is somewhat different: the dominant hierarchical institutional structure for health services delivery is highly stable almost universally, with a central rational rule approach, governed by the medical profession, within financial-budgetary constraints set by state bureaucracy and external donors. However, one pertinent question begs for inquiry: is the health sector in Tanzania relatively better organized and less amenable to corruption compared to the water sector? An intriguing hypothesis, which is articulated by Chowns (2014:370) in the Malawian context, could be that progress in the health sector has been exogenous, driven largely by donors who have themselves been driven by high-profile global efforts to strengthen health systems. If this is the case, then it is important to investigate what donors in the water sector in Tanzania need to do differently to secure similar progress as in the health sector. Doing a comparative research of the two sectors using the governmentality approach will be very interesting.

\section{Comparing governmentalities in the south-south international policy transfer arena}

In the last decade countries of the south, including Tanzania, have been increasingly engaged in international policy transfer activities in order to improve the delivery of public services. The new trend in the international policy transfer is increasingly shifting from countries of the south engaging with the traditional western countries to forging south-south cooperation with Asian countries. In this new policy transfer arena, countries of the south copy and emulate development models and policies from south to south. However, these countries have continued to rely on bilateral and multilateral financial support from the traditional western countries. The result of this practice is a double-edged governmentality involving the host country, south-south countries and traditional western countries. It will therefore be very interesting to unravel these governmentalities by doing a comparative research in East African countries of Tanzania, Kenya and Uganda in the quest to understand how they affect the provision of public services in those countries. 


\section{Comparative research on ICTs/mobile phone-induced accountability interventions}

ICTs and mobile phones in Africa have essentially become the fourth basic need next to food, clothes and shelter. This indicates how relevant and significant these technologies have become to our lives. Their positive/negative impacts on every aspect of our lives cannot be overemphasised. In this study, I have investigated whether public officials in Tanzania are willing to accept information generated by these technologies in order to improve the delivery of public services and enhance accountability. However, there is still much room for further comparative research with other African countries. The use of a governmentality approach in doing a comparative research on a similar topic in other African countries will bring interesting results which can be compared to Tanzania.

\section{A comparative Q-Method study on accountability discourses of Members of Parliament and councillors}

Accountability discourses of MPs and councillors in Tanzania could be indeed very different from those in other African countries. One way to understand these differences would be to do a comparative Q-method research to understand these discourses in selected African countries. However, it will be interesting to understand such differences and their impact on accountability practices beyond formal settings using the governmentality approach. This will permit a much deeper and wider analysis of accountability because the governmentality approach is capable of analysing accountability beyond formal settings.

\subsection{Going with the grain or against the grain}

At the very end of this dissertation, it is appropriate to speculate about political implications of my research for Tanzania. I choose to situate the implications in the 'African grain' debates. The African grain referred to builds on the governmentality concept used in this study. It means a particular way of life which is embedded in the social fabric of African societies and conditioned by society's ideas, culture, beliefs, traditions and values. This way of life is only susceptible to changes that reflect its practices and constitution. The debate on the African grain is twofold: whether to go with the grain by introducing good governance reforms that reflect its practices and constitution; or going against these same practices and constitutions, for example by imposing NMP reforms. Each choice has political implications for Tanzania.

Scholars of diverse persuasion have attempted to unravel the two sides of the debate. Tim Kersall is one of the notable figures in this debate. His popular work entitled "Going with the Grain in African Development" (Kersall, 2008) is particularly illuminating. In this work, Kersall identified a core set of beliefs and values - concerning power, accountability and social morality - that are widely observed across sub-Saharan Africa, and proven extremely durable and powerful drivers of behaviour. He argues that western institutions sit ill alongside these traditions, while the institutions that work well in solving collective action problems and providing public goods are those that harness the motivating forces of family, ethnicity or religion (Kersall, 2008). Kersall's argument reinforces the notion that what works in western countries necessarily cannot work in Africa. Thus, going with the African grain is imperative, particularly in a context of donor-driven reforms which are being constantly implemented in

Africa. In terms of policy designs this would mean recognising that 'development pathways are varied and circuitous. As long as inclusive growth is rapid, a seeming excess of order or a seeming excess of chaos may be less a signal that things are off-track than part of the mediumterm nature of things... To achieve progress, we need to begin by seeing things as they are, and 
to work from there. If we do that, we have the possibility of forward movement. This is the essence of working with the grain' (Levy, 2014). Equally, going with the grain would in practice imply becoming complicit by accepting tolerable levels of corruption, strategies of extraversion, rent seeking, allowing clientelistic politics and eschewing multi-party democracy while finding ways to gradually and incrementally impose restraints from above and below to weed out such practices.

Goran Hyden (2006) has used the concept of the 'economy of affection' in his study of African social and political life to illuminate the African grain. Although the notion of African grain is not directly mentioned in his analyses, his arguments underscore the importance of 'the going with/against the grain' debate. In particular, Hyden explains the economy of affection as a network of support, communications and interaction among structurally defined groups connected by blood, kin, community or other affiliations, for example, religion (Hyden, 2006: 3). It consists of personalized power relations expressed in patronage or clientelism having both lateral and vertical dimensions centered on the reciprocal exchange of values (ibid). Hyden's economy of affection reaffirms the notion of informal institutions which are very powerful and often occupy a central position in the African social and political life. Thus, what works and what does not work in African development endeavours will depend on this configuration, i.e. going with this apparent African grain or against it.

Distinguishing relational accountability from vertical and horizontal accountability in the context of general budget support in Tanzania, Tilley (2014) also highlights 'the going with/against the grain' debate. Tilley argues that relational accountability is hegemonic (in unofficial circles) underpinned by implicit and informal rules; while vertical and horizontal accountability is the logical and only possible response to donors insisting on result-based accountability as conditionality for general budget support (Tilley, 2014). Tilley's argument challenges formal accountability reforms advocated by donors which are going against the African grain, i.e. informal rules that shape and influence governance practices in Africa. In other words, Tilley seems to suggest that donor accountability reforms are working against the African grain, rendering them to having no real traction in the quest to improve public service delivery.

Thus, it would appear that the political implications for what to do next in Tanzania have to be beyond the 'than going with/against the grain' choice. For instance, going with the grain may also mean accommodating bureaucratic pathologies and malpractices such as strategies of extraversion and corruption which have negative effects on the quest for service delivery improvements. After all, as argued by Chowns (2004), positive social change very often requires going against the grain. Thus, in that case, going with the grain that nurtures strategies of extraversion, corruption, and other forms of social injustices may not be an ideal thing to do. However, going against the grain may be detrimental as well. Breaking out of the current 'way of life' which incentivizes and sustains opportunities for strategies of extraversion and corruption as a way of obtaining resources to provide services to the community may deprive the community of the same much needed resources for various development endeavours, including water services. Thus, there is a need to approach the 'African grain' much more carefully.

It is for this reason that analysing accountability from a governmentality perspective will permit an analytic purchase which can provide a balanced approach in the 'African grain' debate. In particular, governmentality is a suitable framework for analysing accountability practices, 
because it is capable of analysing accountability in formal and informal settings and its interactive dynamics altogether. Thus, in order to steer the existing governmentalities between public officials, international donors and the society in a more positive direction, there is a need to go with the grain by accepting tolerable levels of corruption, and strategies of extraversion. The next step will entail gradual and incremental break out of the current system which exacerbates corruption and strategies for extraversion, in essence the tragedy of Africa. Only by having a more encompassing, balanced incremental and gradual approach to various conflicting governmentalities, the people of Tanzania can start to fight corruption, and maybe introduce other changes that draw on the good elements of governmentality. The starting point to assemble this governmentality is to acknowledge the influences of pre-colonial, colonial and post-colonial governmentalities that have shaped present day accountability practices of public officials and the society at large. Only a mentality change among a majority of the Tanzania people itself can usher in new rationalities and technologies to eliminate extraversion and bring in an ecologically sustainable form of 'bio politics'.

Notably, an assemblage of the proposed governmentality has to be anchored in an interface between the personal and the collective/state, i.e. a mixture of notions of disciplining people from above and notions of self-discipline. The former would be ineffective if they would not plug into the conduct of the latter. Achieving such governmentality is not an easy thing and will not be an overnight phenomenon. It requires political will and deliberate actions from the top leadership of the country and a change of mentality from the society.

Revisiting Nyerere's Arusha Declaration is imperative in this case ${ }^{31}$. The Arusha Declaration of 1967, among other things, laid the first ever foundation of massive internalised restraints on public officials. The main thinking in the declaration was that: a self-restraint society will breed self-restraint leaders who will occupy public offices in national and local governments. When serving in these positions, these leaders will be self-restrained in using power not in a manner that promotes opportunities for strategies of extraversion and corruption, but in a way that fosters collective purposes of the society at large. Thus, only a mentality change through selfsubjectification and discipline can usher in a positive governmentality that can work for public officials, donors and the society.

How to go about this will require gradual steps and incremental change. This means that the government needs to embrace logical relentless incrementalism in this direction as overall, long run policy approach. It is impossible to stop corruption and strategies of extraversion overnight. Thus, revisiting the Arusha declaration, in this context, would mean that the government should develop strong views where investments in the economy are most needed, even if the money for envisaged investments is graft. As East Asian countries success stories suggest, they intervened in the market, got prices wrong, engaged in rent-seeking and corruption, used clientelistic politics, and eschewed multi-party politics and yet they recorded significant economic development progress. Of course, Tanzania is not Asia, but as noted by Kersall (2008) these countries did not adopt Western ways of doing things wholesale; rather, they selected certain elements of the Western experience which they then combined with indigenous strengths, creating distinctive new models of development. Hence, for this to work in Tanzania

\footnotetext{
31 The Arusha Declaration and TANU's Policy on Socialism and Self-Reliance was promulgated in Arusha, Tanzania in 1967. The declaration was a formal policy statement that sought to steer the country in a socialist development path.
} 
the state's extractive, regulative, and distributive capacities have to be improved to benefit all Tanzanians. Meanwhile, in the light of the relentless incrementalism, tolerable levels of graft and strategies of extraversion could be allowed in the transition period to let members of the parliament and councillors serve their communities and constituencies better. 


\section{References}

Agrawal, N., Ahmed, Z., Mered, M., and Nord. R.1993.Structural Adjustment, Economic Performance, and Aid Dependency in Tanzania. Working Papers. Eastern Africa Department. The World Bank and Fiscal Affairs and African Departments International Monetary Fund.

Andrew, M. 2013. Do International Organizations Really Shape Government Solutions In Developing Countries? CID Working Paper No. 264. Cambridge, MA: Center for International Development, Harvard University.

Attfield, I. 2013. Big, fast, accountable results now, Mr. President! Retrieved from https://dfid.blog.gov.uk/2013/03/19/big-fast-accountable-results-now-mr-president/

Babeiya, E. 2011. Electoral corruption and the politics of elections financing in Tanzania. Journal of Politics and Law Vol. 4, No. 2; September 2011.

Bailur, S. and Gigler, B.S. 2014 'Introduction: The Potential for Empowerment through ICTs', in B-S. Gigler and S. Bailur (eds), Closing the Feedback Loop. Can Technology Bridge the Accountability Gap? Washington DC: World Bank.

Bana B. 1995. Human Resources Management in Tanzania Local Government Institutions: The Case of Dar es Salaam City Council. Unpublished Thesis, Dar es Salaam University Press, Dar es Salaam.

Bana, B. and McCourt, W. 2006. 'Institutions and Governance: Public Staff Management in Tanzania', Public Administration and Development 26, 395-407.

Bayart, J.F. 2009. The State in Africa. The Politics of the Belly. $2^{\text {nd }}$ Edition. Polity Press. Cambridge.

Bayart, J.F., Ellis, S. and Hibou, B. 1999. The Criminalization of the State in Africa. Bloomington: Indiana University Press.

Bernard, H. R. 2006. Research methods in anthropology. Lanham, MD: Altamira Press.

Beyerle, S. 2014. Curtailing Corruption: People Power for Accountability and Justice. Lynnee Rienner Inc. Boulder, Co.

Boesen, J. Havnevik, J.K. Koponen, J. Odgaard, Ric (eds) 1986. Tanzania Crisis and Struggle for Survival. Scandinavian Institute of African Studies, Upscale.

Booth, D. 2011. Governance for Development in Africa: Building on What Works. London: Overseas Development Institute.

Borowiak, C.T. 2007. Accountability Debates: The Federalists, the Anti-Federalists, and Democratic Deficits. The Journal of Politics, Vol. 69, No. 4, pp. 998-1014.

Bourque, E. C. 2010. Urban Governance and unequal Geographies of Water in Buguruni Ward. Dar es Salaam: Tanzania Kings College London.

Bovens, M. 2005. Analysis and Assessing Public Accountability: A Conceptual Framework. A Paper Presented at Conference on Accountable Governance: An International Research Colloquium, Belfast: Queens University, October 20-22. 
Bovens, M. 2007. Analysing and Assessing Accountability: A Conceptual Framework. European Journal of Law, 13(4), 447-468.

Bovens, M. 2010. Two Concepts of Accountability: Accountability as a Virtue and as a Mechanism', West European Politics, 33: 5, 946 - 967.

Bovens, M., and Schillemans, T. 2008. Does Public Accountability Work? An assessment tool. Public Administration 86(1), 225-242.

Bovens, M.1998. The Quest for Responsibility: Accountability and Citizenship in Complex Organisations, Cambridge: Cambridge University Press.

Brady, R.S.M. 2013. Where is the System in the Systemic Risk Literature? Virginia, US, the MITRE Corporation. In Povey, J. et al., 2013. The Functionality of Leximancer Software as an Analytic Tool for Semi Structured Interview Data Exploring EvidenceBased Policy in Practice from the Perspectives of Academic Social Scientists and Policymakers. AMSRS Conference $5^{\text {th }}-6^{\text {th }}$ September, Sydney, Australia.

Brandsma, G.J. 2010. Backstage Europe: Holding Comitology Committees to Account, Ph.D. Thesis, Utrecht University.

Bratton, M. 2010. Citizens Perceptions of Local Government Responsiveness in Sub-Saharan Africa. Cape Town: Afro Barometer.

Bratton, M. and Logan, C. 2013. Voters but Not yet Citizens: The Weak Demand for Vertical Accountability. Cape Town: Afro Barometer.

Brinkerhoff, D.W. and Goldsmith A.A, 2012. Clientelism, Patrimonialism and Democratic Governance: An Overview and Framework for Assessment and Programming. U.S. Agency for International Development Office of Democracy and Governance.

British journal of Sociology 43 (2): 173-205.

Brown, S.R. 1996. 'Q methodology and qualitative research', Health Research 6, 4: 561-567.

Carlitz, R. 2013. 'Improving Transparency and Accountability in the Budget Process: An Assessment of Recent Initiatives', Development Policy Review 31, s1: S49-S67.

Castells, M. 1996. The Rise of the Network Society. The Information Age: Economy, Society and Culture, vol. I. Blackwell, Oxford, UK.

Cendon, A.B. 2000. Accountability and Public Administration: Concepts, Dimensions, Developments. Unpublished Paper.

Chalmers, I. and B. Setiyono, 2012. 'The struggle against corruption during the democratic transition: theorizing the emergent role of CSOs', Development and Society 41, 1: 77102.

Chayes, S. 2015. Thieves of State: Why Corruption Threatens Global Security. New York: W.W. Norton and Company Inc.

Chowns, E.E. 2014. The Political Economy of Community Management: A Study of Factors Influencing Sustainability in Malawi's Rural Water Supply Sector. Unpublished Dissertation. University of Birmingham. 
Connolly, P. 1998. 'Dancing to the wrong tune': ethnography generalization and research on racism in schools. In: P. Connolly and B. Troyna (eds.), Researching Racism in Education: Politics, Theory, and Practice. Buckingham, UK: Open University Press, pp. 122-139.

Copeland, G.W., and Samuel C. P. 1998. "Parliaments and Legislatures" in George Thomas Kurian (Ed.) World Encyclopedia of Parliaments and Legislatures vol. I. Washington D.C.: Congressional Quarterly Inc.

De Mesquita B.B. and Smith, A. 2015. ; 'Tanzania's Economic and Political Performance: A District-Level Test of Selectorate Theory', in S.O. Wolf, J. Schöttli, D. Frommherz, K. Fürstenberg, M. Gallenkamp, L. König, M. Pauli, eds. Politics in South Asia. Culture, Rationality and Conceptual Flow. Heidelberg: Springer, 31-48.

De Mesquita, B.B. and Smith, A. 2012. The Dictator's Handbook: Why Bad Behavior is Almost Always Good Politics. Philadelphia: Public Affairs.

Dean, M. 2010. Governmentality: Power and Rule in Modern Society. Califonia. SAGE Publication Limited.

Death, C. 2011. Africa, governmentality, and the international: Reflections on agency and the climate change negotiations. Paper prepared for the BISA-Africa and International Studies ESRC seminar series \#4'African agency: Implications for International Relations theory' Department of International Politics, City University, 14 September.

Dery, D. 1984. Problem Definition in Policy Analysis, Lawrence, Kansas, University Press of Kansas 160 pp.

Dery, D. 2000. Agenda Setting and Problem Definition. Policy Studies, Vol. 21, No. 1, 1- 31.

Dickinson, N., and Bostoen, K. 2013. Using ICT for Monitoring Rural Water Services. From Data to Action, Triple-S Working Paper, and The Hague: International Rescue Committee.

Dill, B. 2010. Public-Public Partnerships in Urban Water Provision: The Case of Dar es Salaam. Journal of International Development 22, 611-624.

Druckman, N.J., and Chong, D. 2007. Framing Theory, Annual Review. Political Science 10:103-126.

Dubnick, M. 2005. Accountability and the Promise of Performance: In Search of the Mechanisms Public Performance and Management Review, Vol. 28, No. 3 pp. 376417.

Dubnick, M. and Justice, J.B. 2004 Accounting for Accountability. Paper Prepared for Delivery at the Annual meeting of the American Political Science Association.

Easton, D. 1953. The Political System: An Inquiry of the State of Political Science. New York, Wiley.

Edwards, D., and McGee, R. (eds) 2016. Opening Governance: Change, Continuity and Conceptual Ambiguity. IDS Bulletin 47-1.

Edwards, S. 2014. Toxic Aid. Economic Collapse and Recovery in Tanzania, Oxford, Oxford University Press. 
Eisenhardt, K. 1989. Agency theory: An assessment and review. Academy of Management Review 14(1): 57-74.

Esaiasson, P., and Narud, H.M. 2013. Between-Election Democracy: The Representative Relationship after Election Day. Colchester: ECPR Press.

Ewald, J. 2002. "Economic Reforms and Democratisation in Tanzania: The Case of the Election and Conflict Management in East Africa, 28/2-3 March.

EWURA, 2012. Water Utilities Performance Report 2010/ 2011: Regional Water Utilities and DAWASCO. Dar es Salaam, Tanzania.

Feierman, S. 1990. Peasant Intellectuals: Anthropology and History in Tanzania. Madison: University of Wisconsin Press.

Fjeldstad, H.O. 2003. Fighting Fiscal Corruption: Lessons from the Tanzania Revenue Authority. Public Administration and Development 23, 165-175.

Flyvjerb, B. 2006. Five Misunderstandings about Case-Study Research. Qualitative Inquiry $12 ; 219$.

Foucault, M. 1977. Discipline and Punish: the Birth of the Risa. London: Allen Lane.

Foucault, M. 1988. 'Technologies of the Self, pp. 16-49 in Luther H. Martin, Huck Gutman and Patrick H. Hutton (eds) Technologtes of the Self: A seminar with Michael Foucault. Amherst: University of Massachusetts Press.

Foucault, M. 1990. The Case of the Self: London: Penguin.

Foucault, M. 1991b. 'Questions of Method', pp. 73-86 in Graham Burchell, Colin Gordon and Peter Miller (eds) The Foucault effect: Studies in Governmentality. Hemel Hempstead: Harvester Wheatsheaf.

Foucault, M. 1993. 'About the Beginning of the Hermeneutics of the Self', Political Theory 21(2): 198-227.

Foucault, M. 1997. 'Security, Territory, and Population', pp. 67-71 in Ethics: Subjectivity and Truth, ed. by Paul Rabinow. New York: The New Press.

Foucault, M. 2000a. 'The subject and power', pp. 326-48 in Power. Essential Works of Michael Foucault, Vol Ill, ed. by James D. Faubion. New York: The New Press.

Foucault, M. 2000b. The political technology of individuals', pp. 403-17 in Power Essential Works of Michael Foucault Vol Ill, ed. by James D. Faubion. New York: The New Press.

Foucault, M. 2007. Security, Territory, Population. Lectures at the College de France 197778. New York: Palgrave.

Foucault, M.1991a. 'Governmentality', pp. 87-104 in Graham Burchell, Colin Gordon and Peter Miller (eds) The Foucault effect: Studies in Governmentality. Hemel Hempstead: Harvester Wheatsheaf.

Fung, A. Gilman, H.R. and Shkabatur, J. (2013) 'Six Models for the Internet + Politics', International Studies Review 15: 30-47. 
Furnivall, J. S. 1956. Colonial Policy and Practice. Cambridge, UK: Cambridge University Press.

Georgiadou, Y.; Bana, B.; Becht, R.; Hoppe, R.; Ikingura, J.; Kraak, M.-J.; Lance, K.; Lemmens, R.; Lungo, J.H.; McCall, M.; Miscione, G. and Verplanke, J. 2011. Sensors, empowerment, and accountability: A digital earth view from East Africa. International Journal of Digital Earth 4 (4): 285-304.

Gerring, J. 2004. What is a Case Study and What Is It Good for? American Political Science Review Vol. 98, No. 2, 341-354.

Gigler, S. and Bailur, S. (eds) 2014. Closing the Feedback Loop: Can Technology Close the Accountability Gap? Washington DC: World Bank.

Glickman H. 1972. Traditional Pluralism and Democratic Processes in Mainland Tanzania, in Socialism Tanzania, vol.1, Politics, ed. Lionel Cliffe and John S. Sahul. Nairobi: East African Publishing House, 127-44.

Gouldner, A.W. 1954. Patterns of Industrial Bureaucracy. Glencoe, IL: Free Press.

Grindle, M.S. 2010. Good Governance: The Inflation of an Idea. CID Working Paper No. 202. Cambridge, MA: Harvard University.

Ha, E.H. 2015. 'Attitudes toward clinical practice in undergraduate nursing students: A Q methodology study', Nurse Education Today 35, 6: 733-739.

Harrison, G. Mulley, S. Holtom, D. 2009 Tanzania: a Genuine Case of Recipient Leadership in the Aid System? In Whitfield, L. (éds.), The Politics of Aid: African Strategies for Dealing with Donors, Oxford, Oxford University Press, 2009, p. 271--298.

Harvey, P. and Reed, B. 2004. Rural Water Supply in Africa. Building Blocks for Hand pump Sustainability, Loughborough: Loughborough University Water Engineering and Development Centre.

Haugaard, M. 2015. 'Concerted Power Over'. Constellations Volume 22, Number 1, 2015

Heilman, B. and Ndumbaro, L. 2002. 'Corruption, Politics, and Societal Values in Tanzania: An Evaluation of the Mkapa Administration's Anti-Corruption Efforts', African Journal of Political Science 7, 1: 1-20.

Hellmann, O. 2014. Political Corruption in the Developing World: The Effects of Colonial Rule and Decolonization. Paper Prepared for the ECPR General Conference, Glasgow, 3-6 September.

Helmke, G. and Levitsky, S. 2004. Informal Institutions and Comparative Politics: A Research Agenda. Politics 2, 4: 725-740.

Hoffman, B.D. 2006. Political Accountability at the Local Level in Tanzania. Unpublished Dissertation. University of Califonia Sandiago.

Hood, C. 1998. Contemporary Public Management: A New Global Paradigm? Public Policy and Administration. 10 (2): 104-117.

Hoppe, R. 2008. 'Scientific Advice and Public Policymaker's Discourses on Boundary Work', Poiesis and Praxis 6, 3: 235-263. 
Hyden, G. 2006. Between State and Community: Challenges to Redesigning Governance in Africa. Conference Paper on Designing Constitutional Arrangements for Democratic Governance in Africa: Challenges and Possibilities. Indiana University, Bloomington, March, 30-31.

Hyden, G. 2010. Political accountability in Africa: is the glass half-full or half-empty? London: Overseas Development Institute.

Hyden, G. 2013. African Politics in Comparative Perspective. New York: Cambridge University Press.

Ibbott, R. 2014. Ujamaa: The Hidden story of Tanzania's Socialists villages. Cross road Books.

Illife, J. 1969. Tanganyika under German Rule, 1905-1912.Cambridge: Cambridge University Press.

Illife, J. 1979. A Modern History of Tanganyika. Cambridge: Cambridge University Press. Information-and-communication-technologies-icts-monitoringsustainable-servicedelivery. Accessed on $16^{\text {th }}$ April, 2016.

Innerarity, D. 2013. The Democracy of Knowledge. New York: Bloomsbury.

Janus, H., and Keijzer, N. 2015. Big Results Now? Emerging Lessons from a Result-Based Aid in Tanzania Discussion Paper 4/2015. Bonn, Germany: Deutsches Institut für Entwicklungspolitik (German Development Institute).

Jeffares, S. and Skelcher, C. 2011. 'Democratic Subjectivities in Network Governance: A Q Methodology Study of English and Dutch Public Managers', Public Administration 89, 4: $1253-1273$.

Jiménez, A. and Pérez-Foguet, A. 2010. Building the role of local government authorities towards the achievement of the human right to water in rural Tanzania. Natural Resources Forum 34(2): 93-105.

Jiménez, A. and Pérez-Foguet, A. 2011. Water point mapping for the analysis of rural water supply plans: Case study from Tanzania. Journal of Water Resources Planning and Management 137(5): 439-447.

Jiménez, A. and Pérez-Foguet, A. 2012. Quality and year-round availability of water delivered by improved water points in rural Tanzania: Effects on coverage. Water Policy 14(2012): 509-523.

Joshi, A. 2014. 'Reading the Local Context: A Causal Chain Approach to Social Accountability', IDS Bulletin 45.5: 23-35

Kaliba, A.R.M. 2002. Participatory Evaluation of Community-Based Water and Sanitation Programs: The Case of Central Tanzania. Unpublished Thesis. Kansas State University.

Kassenga, G.R. 2007.The Health-related microbiological quality of bottled drinking water solid in Dar Es Salaam, Tanzania. Journal of Water and Health, 5, 179-185 
Katomero J, Hoppe R, Wesselink A, Bana B, Nganyanyuka K .2013. How Corruption Stifles Problem Framing and Responsive Governance: The Case of Water and Health Services in Tanzania. 14th N-AERUS Conference, Enschede 12th to 14th September 2013.

https://docs.google.com/viewer?a=v\&pid=sites\&srcid=ZGVmYXVsdGRvbWFpbnxzZW1hd GFuemFuaWF8Z3g6NzljMmM0MmVkNGQ5ODczNA

Kaufman, R.R. 1974. The Patron-Client Concept and Macro-Politics: Prospects and Problems. Comparative Studies in Society and History 16(4): 284-308.

Kelsall, T. 2003. 'Rituals of verification: indigenous and imported accountability in Northern Tanzania', Africa 73, 2: 174-201.

Kelsall, T. 2008. Going with the Grain in African Development. London: Overseas Development Institute.

Kenney, C.D. 2000. Reflections on Horizontal Accountability: Democratic Legitimacy, Majority Parties and Democratic Stability in Latin America. A Paper Prepared for the conference on Institutions, Accountability, and Democratic Governance in Latin America, Kellogg Institute for International Studies, University of Notre Dame, May 8-9.

Kersall, T. 2000. Governance, Local Politics and Districtization in Tanzania. The 1998 Arumeru Tax Revolt. African Affairs 99, 533-531.

Khan, M.H. and Gray, H. 2006. State weakness in developing countries and strategies of institutional reform: Operational implications for anti-corruption policy and a case study of Tanzania. London: London School of Economics and Political Science.

Killian B, 2014. 'A Proposed Structure of the Union in Tanzania: Political Parties at a Crossroad', African Review 41, 1: 116-138.

Kiragu, K.; Mukandala R.; Mutahaba G.; and Bana B. 2009. Strengthening the Policy Development Process. President Office Public Service Management and the Cabinet Secretariat, Office of the Chief Secretary. Final Report.

Kisanga, D. 2013. Hunt for water thieves in Dar starts on high note. Dar es Salaam, Tanzania: The Guardian.

Kjellen, M. 2000. Complementary water systems in Dar es Salaam, Tanzania: The case of water vending. International Journal of Water Resources Development 16(1): 143154.

Kjellen, M. 2006. From Public Pipes to Private Hands: Water Access and Distribution in Dar es Salaam, Tanzania. Stockholm: Department of Human Geography, Stockholm University.

Krolikowski, A. 2014. Can Mobile-Enabled Payment Methods Reduce Petty Corruption in Urban Water Provision? Water Alternatives 7(1): 235-255

Kyessi, A. 2005. Community-based urban water management in fringe neighborhoods: The case of Dar es Salaam, Tanzania. Habitat International 29(1): 1-25. 
Lawson, A. and Rakner, L. 2005. Understanding Patterns of Accountability in Tanzania, Final Synthesis Report. Oxford: Oxford Policy Management.

Lemke, T. 2007. 'An indigestible meal? Foucault, governmentality and state theory, Distinction': Scandinavian Journal of Social Theory, 8:2, 43-64.

Levy, B. 2014. Working with the Grain: Integrating Governance and Growth in Development Strategies: Oxford University Press.

Lindberg, I.S. 2009. Accountability: The Core Concepts and its Subtypes. African Power and Politics Programme, Working Paper No. 1.

Lindberg, S.I. 2010. 'What accountability pressures do MPs in Africa face and how do they respond? Evidence from Ghana', Journal of Modern African Studies, 48, 1:117-142.

Lindner, S. and P. Banoba 2014. Tanzania: Overview of Corruption and Anti-Corruption. U4 Expert Answer. Transparency International.

Livingston, S. and Walter-Drop, G. 2012. Information and communication technologies in areas of limited statehood. SFB-Governance Working Paper Series No. 38. Berlin: Research Center (SFB) 700.

Lofchie, M.F., 2014. The Political Economy of Tanzania. Decline and Recovery, University Park, Philadelphia, University of Pennsylvania Press, 2014.

Loureiro, M., Cassim A., Darko, T., Katera, L., and Salome, N. 2016. When Does the State Listen? Opening Governance. IDS Bulletin Vol. 47 No. 1

Lugard, F.D, 1922. The Dual Mandate in British Tropical Africa. Edinburg and London: William Blackwood \& Sons.

Lukes, S. 1974. Power: A radical view. London: Macmillian.

Lynge, C. 2009. Tanzania - The Darling of the Donor Community?-A critical Review of the Failure of Past Development Aid Efforts. Unpublished Master's Thesis. Copenhagen Business School

Mallya, E. 2011. 'Accountability and Transparency at Grassroots Level: The Experience of Tanzania', Paper presented at 'Democratic Transition in East Africa: Governance and Development at the Grassroots' Arusha, 17-18 November 2009. Dar es Salaam: Research and Education for Democracy in Tanzania.

Mamdani, M. 1996. Citizen and Subject. Princeton, NJ: Princeton University Press.

Mandara, C.G., Butijn, C. and Niehof, A. 2013. Community management and sustainability of rural water facilities in Tanzania. Water Policy 15(2): 79-100.

Mandelbaum, M. 2011. Democracy's Good Name. The Rise and Risks of the World's Most Popular Form of Government. Public Affairs. New York.

Marobhe, N.J.M, 2008. Water Supply in Tanzania and Performance of Local Plant Materials in Purification of Turbid Water. Unpublished Dissertation. Royal Institute of Technology, Stockholm Sweden. 
Marquette, H. and Peiffer, C. 2015. Collective Action and Systemic Corruption. Paper Presented at the ECPR Joint Sessions Workshop, University of Warsaw, $29^{\text {th }}$ March $2^{\text {nd }}$ April.

Matenge, F.J. 2012. 'Parliamentary Supremacy in Tanzania: Rhetoric and Reality', Journal of Education, Humanities and Sciences 1, 1: 38-56.

Mayer-Schönberger, V. and Lazer, D. 2007. From electronic government to information government. In Mayer-Schönberger, V. and Lazer, D. (eds), Governance and information technology: From electronic government to information government, $\mathrm{pp}$. 1-14. Cambridge: MIT Press.

McGee, R. and Carlitz, R. 2013 Learning Study on 'the Users' in Technology for Transparency and Accountability Initiatives: Assumptions and Realities, Brighton: IDS.

Melber, H. 2007. (Ed.). Governance and State Delivery in Southern Africa: Examples from Botswana, Namibia and Zimbabwe. Uppsala: Nordiska afrikainstitutet.

Miller, P. and Rose, N. 1990. 'Governing economic life', Economy and Society 19 (1):

Mo Ibrahim Foundation 2014. Ibrahim Index of African Governance, 2014: Summary Report. http://static.moibrahimfoundation.org/downloads/publications/2014/2014-iiagsummary-report.pdf. Accessed on September 24, 2015.

Mogella, C. 1987. Local Administration Reforms for Rural Development 1962 - 1982 in Tanzania. PhD Thesis, Ottawa: Carleton University

Montero, G. 2014. As If: The Fiction of Executive Accountability and the Persistence of Corruption Networks in Weakly Institutionalized Presidential Systems. Argentina (1989-2007).Unpublished Dissertation. Georgetown University.

Mugisha, S. and Brown, A. 2010. Patience and action pays: A comparative analysis of WSS reforms in three East African cities. Water Policy 12(5): 654

Mukandala, S.R. 1998. Decentralization and Democracy in Tanzania. University of Dar es Salaam. Dar es Salaam.

Mukandala, S.S. Mushi, and C. Rubagumya C (eds.) Peoples Representatives: Theory and Practice of Parliamentary Democracy in Tanzania. Kampala: Fountain Publishers.

Mukangara, D. 2005.Tanzania. South African Journal of International Affairs, 12.1, 183-204

Mulgan, R. 2003. Holding Power to Account. New York: Palgrave.

Mutahaba, G. 1989. Reforming Public Administration for Development: Experience from Eastern Africa. Kumarian Press INC U.S.A.

Mwakyembe, H.G. 1986. 'The Parliament and the Electoral Process', in I.G. Shivji (ed.) the State and the Working People in Tanzania. Dakar: CODESRIA.

National Bureau of Statistics 2013. 2002 Population and Housing Census. National Population Distribution by Administrative Areas. Dar es Salaam Tanzania.

National Bureau of Statistics and Bunda District Council .2014. Bunda District Social Economic Profile. Dar es Salaam, Tanzania. 
Nganyanyuka K.; Martinez J.; Wesselink, A.; Lungo H.; and Georgiadou Y. 2014. Accessing water services in Dar es Salaam: Are we Counting What Counts? Habitat International Vol.44, 358-366.

Njunwa, M.H.M. 2007. Cooperative Public Service Delivery in Tanzania: Is it contributing to Social and Human Development? Journal of Administration and Governance, 2(1), 32-39.

Norris, P., Frank, R.W., and Martinez F.I. 2014 (eds). Advancing Electoral Integrity. New York: Oxford University Press.

Norton, P. 1998. (ed.). Parliaments and Governments in Western Europe vol. 1. London: Frank Cass.

Norton, P. and Ahmed, N. 1999. "Legislatures in Asia: Exploring Diversity" in Norton, Philip and Nizam Ahmed (eds.) Parliaments in Asia. London: Frank Cass.

Norton, P. and Olson, D.M. 1996. The New parliaments of Central and Eastern Europe. London: Frank Cass.

Nyerere, J.K, 1967. Freedom and Unity; Uhuru na Umoja: A Selection of Writings and Speeches, 1952-1965. London: Oxford University Press.

Nyerere, J.K. 1960. “Tanganyika Today: The Nationalist View”. International Affairs 36, no. 1 (January): 43-47.

OECD. 2003. The e-Government imperative. Paris: OECD Publishing.

Olsen, J.P. 2015. 'Democratic Order, Autonomy, and Accountability. Governance': An International Journal of Policy, Administration, and Institutions, Vol. 28, No. 4, pp. 425-440.

Onwuegbuzie A. J., and Leech L. N., 2007. A Call for Qualitative Power Analyses. Quality and Quantity 41:105-121.

Pearce, J.; Dickinson, N. and Welle, K. 2015. 'Technology, Data and People: Opportunities and Pitfalls of using ICT to Monitor Sustainable WASH Services', in T. Schoten and S. Smits (eds), From Infrastructure to Services. Trends in Monitoring Sustainable Water, Sanitation and Hygiene Services, Rugby: Practical Action Publishing.

Pearce, J.; Welle, K. and Dickinson, N. 2013. 'Information and Communication Technologies (ICTs) for Monitoring Sustainable Service Delivery', Conference Paper, The Hague: International Water and Sanitation Centre, http://www.ircwash.org/resources/

Persson, A. Rothstein B, and Teorell J. 2013.Why Anticorruption Reforms Fail: Systemic Corruption as a Collective Action Problem. Governance Vol. 26, No. 3, pp. 449-471.

Pigeon, M. 2012. From Fiasco to Dawasco: Remunicipalising Water Systems in Dar es Salaam. In Pigeon et al., 2012. Remunicipalisation: Putting Water Back into Public Hands. Transnational Institute. Amsterdam.

Poth, S. and Selk, T. 2009. "Principal -Agent Theory and Artificial Information Asymmetry', Politics 29:137-144. 
Presidential Power 2015. Tanzania - As corruption spreads under President Kikwete, Parliament quietly gains strength. Retrieved from URL http://presidentialpower.com/?p=2759. Accessed on 15 September 2015.

Quah S.T.J. (Ed.) 2013. Different Paths to Curbing Corruption: Lessons from Denmark, Finland, Hong Kong, New Zealand and Singapore. Bingley: Emerald Group Publishing Limited.

Ranger, T.1983. "The Invention of Tradition in Colonial Africa", in Hobs Bawm and Ranger (1983:211-62).

Reith, S. 2011. Tanzania after The parliamentary and presidential elections 2010: dawn of a multi-party democratic era? KAS International Reports. http://www.kas.de/wf/doc/kas 21554-1522-2-30.pdf?110112143740. Accessed on $28^{\text {th }}$ September, 2015

Research on Poverty Alleviation (REPOA). 2007a. Framework for Downward Accountability in Local Government Authorities. Submitted to the Prime Minister's Office-Local Government and Regional Administration.

Rioba, 2012. Media Accountability in Tanzania's Multiparty Democracy. Does selfregulation work? Unpublished Dissertation. University of Tampere.

Rose, N. and Miller, P. 1992. 'Political power beyond the state: Problematic of government',

Rottenburg, R. 2009. Far-fetched facts. A parable of development and humanitarian aid (A. Brown and T. Lampert, Trans.). Cambridge, Massachusetts and London, England: The MIT Press.

Schedler, A. 1999. Conceptualising Accountability, in A. Schedler, L. Diamond and M. Plattner (eds), The Self-Restraining State. Boulder CO: Lyne Reinner, pp.13-51

Schillemans, T. 2008. Accountability in the Shadow of Hierarchy: The Horizontal Accountability of Agencies. Public Organization Review, 8(2), 175-194.

Schlimmer, S. and Provini, O. 2015. Politics and Policies in Tanzania. A Comparative Study of Higher Education and Land Policies. ICPP. Panel "Policy Making Between Challenges and Opportunities: An African Perspective.

Schmolck, P. 2014. PQMethod Manual.

http://schmolck.userweb.mwn.de/qmethod/pqmanual.htm accessed on September $2^{\text {nd }} 2015$.

Scott C.J. 1969. The Analysis of Corruption in Developing Nations. Comparative Studies in Society and History, Vol. 11, No. 3. pp. 315-341.

Scott, J. 1990. Domination and the Arts of Resistance: Hidden Transcripts. Yale. Yale University.

Scott, W.R. 2003. Organizations Rational, Natural, and Open Systems. Pearson Education LTD.

Shivji, I.G. and Majamba, H.I. 2004. Constitutional and Legal System of Tanzania: A Civics Sourcebook. Dar es Salaam: Mkuki na Nyota Publishers. 
Sigley, G. 2006. 'Chinese governmentalities: government, governance and the socialist market economy’, Economy 8 Society 35(4): 487-508.

Sinclair, A. 1996. 'The Chameleon of Accountability: Forms and Discourses', Accounting, Organisations and Society, 20: $219-237$.

Smiley S.L. 2013. Complexities of Water Access in Dar es Salaam, Tanzania. Applied Geography 41, 132-138. Elsevier.

Sogunro, A. (2014). Why I am Corrupt: In Defense of Nigerians. Retrieved from http://ayosogunro.com/2014/06/11/why-i-am-corrupt-in-defense-of-nigerians-byayo-sogunro/ accessed on September 25, 2014.

Stålgren, P. 2006. Corruption in the Water Sector: Causes, Consequences and Potential Reform. Swedish Water House Policy Brief Number 4. Stockholm International Water Institute.

Star, S. L. and Griesemer J.R, 1989. Institutional Ecology, Translations and Boundary Objects: Amateurs and Professionals in Berkeley's Museum of Vertebrate Zoology, 1907-39. Social Studies of Science, Volume 19, Issue 3, 387-420.

Stchaz, F. 2013. 'Fighting Corruption with Social Accountability: A Comparative Analysis of Social Accountability Mechanism's Potential to Reduce Corruption in Public Administration'. Public Administration and Development. 33, 161-174.

Steffensen J.; Tidemand P.; Mwaimpopo E. 2004. A Comparative Analysis of Decentralization in Kenya, Tanzania and Uganda. Country Study - Tanzania.

Stephenson, W. 1954. The Study of Behavior: Q-Technique and Its Methodology. Chicago, IL: University of Chicago Press.

Stone, D. 1999. 'Learning Lessons and Transferring Policy across Time, Space and Disciplines', Politics, 19(1): 51-59.

Tambila, K.I. 2004. 'The Ups and Downs of the Tanzanian Parliament 1961-1994', in R.S.

Taylor, J.C.1963. The Political Development of Tanganyika. Stanford and London: Stanford University Press.

Taylor, L and Broeders D., 2015. In the name of Development: Power, Profit and the Datafication of the global South. Geo-forum 64. 229-237

Therkildsen, O. 2000. 'Public Sector Reform in A Poor, Aid-Dependent Country, Tanzania', Public Administration and Development 20, 1: 61-71.

Thompson, M.P.A. 2004. ICT, Power, and Developmental Discourse: A critical analysis. The Electronic Journal on Information Systems in Developing Countries 20: 1-25. http://www.ejisdc.org accessed on15April, 2016.

Tilley, H. 2014. The Political Economy of Aid and Accountability: The Rise and fall of Budget Support in Tanzania. Burlington: Ashgate.

Tom, W. 2010. Public accountability and PPP's: how to obtain good public accountability in complex settings? Third Biennial Conference of ECPR Standing Group on Regulatory Governance, 17-19 June, University College, Dublin, Ireland p. 31. 
Tordoff, W. 1993. Government and Politics in Africa. Indiana: Indiana University Press.

Transparency International. 2013a.Corruption Perceptions Index. http://www.transparency.org/files/content/corruptionqas/Country profile Tanzania 2014.pdf accessed on September 24, 2014.

Transparency International. 2013b. Global Corruption Barometer. http://www.transparency.org/gcb2013 Accessed on September 25, 2014.

Transparency International. 2014. Corruption Perceptions Index. http://www.transparency.org/policy research/surveys_indices/cpi Accessed on September 24, 2015.

Tsubura, M. 2014. Accountability and Clientelism in Dominant Party Politics: The Case of a Constituency Development Fund in Tanzania. Unpublished Thesis. University of Sussex.

UN. 2010. General Assembly Resolution 64/292: The Human Right to Water and Sanitation. A/RES/64/292. United Nations.

UN. 2013. 'Goal 7: Ensure Environmental Sustainability.' Retrieved 5 January 2015, from http://www.un.org/millenniumgoals/environ.shtml

United Republic of Tanzania .2011.The Enhanced National-Anti-Corruption Strategy and $\begin{array}{llll}\text { Action Plan } & \text { (NACSAP } & \text { II) } & \text { 2008-2011 }\end{array}$ http://www.parliament.go.tz/index.php/documents/parliament/all/all/10 Accessed on September 25, 2014.

United Republic of Tanzania. 2010. Demographic and Health Survey: the Tanzania Water and Sanitation Programme Report 2011. Dar es Salaam: Government Printer.

United Republic of Tanzania. 2013. WPMS Database Analysis Report. Dar es Salaam, Tanzania: Ministry of Water.

United Republic of Tanzania. 2013a. Tanzania Big Results Now! Road Map - National Key Result Area Water 2013/14 - 2015/16. Dar es Salaam: Ministry of Water.

United republic of Tanzania. 2013b. The Water Sector Status Report 2013. Dar es Salaam, Tanzania: Ministry of Water.

United Republic of Tanzania. 2015. Tanzania Development Vision 2015: Big Results Now: 2013/2014 Annual Report. Dar es Salaam, Tanzania: President's Delivery Bureau.

Van de Walle, N. 2009. 'The Democratization of Political Clientelism in sub-Saharan Africa', Paper Presented at the 3rd European Conference on African Studies, Leipzig, Germany, June 4-7 June.

Venugopal, V. and Yilmaz, S. 2010. 'Decentralization in Tanzania: An Assessment of Local Government Discretion and Accountability', Public Administration and Development, 30, 3: 215-231.

Vernplanke, J. and Geordiadou, Y. 2016. Challenges of Water Point Mapping. Unpublished paper. 
Von Freyhold, M. 1979. Ujamaa villages in Tanzania. Analysis of a social Experiment. London: Heinemann Book.

Walters, W. 2004. 'Some critical notes on "governance"', Studies in Political Economy, 73: $27-46$.

Wang, V. 2005. The Accountability Function of Parliament in New Democracies: Tanzanian Perspectives. Working Paper No. 5: Chr. Michelsen Institute Development Studies and Human Rights

Water Aid. 2008. Why did city water fail? The Rise and Fall of Private Sector Participation in Dar es Salaam's water supply. Tanzania: Water Aid.

Watts, S. and Stenner, P. 2012. Doing Q Methodological Research: Theory, Method \& Interpretation. Thousand Oaks: SAGE Publication.

Weber, M. 1991. "Politics as a Vocation.” In From Max Weber, ed. Heinrich Gerth and C. Wright Mills. London: Routledge.

Welle, K. 2010. Water Point Mapping in East Africa. Based on a Strategic Review of Ethiopia, Tanzania, Kenya and Uganda. London: Water Aid.

Welle, K.; Williams, J.; Pearce, J.; and Befani, B. 2015. Testing the Waters: A Qualitative Comparative Analysis of the Factors Affecting Success in Rendering Water Services Sustainable Based on ICT Reporting, Brighton: Making All Voices Count, http://www.makingallvoicescount.org/wpcontent/uploads/2015/10/MAVC_WaterAid_FINAL-report_online-version.pdf accessed on16 April, 2016.

Wesselink, A., Hoppe, R. and Lemmens, R. 2015. 'Not Just a Tool. Taking Context into Account in the Development of a Mobile App for Rural Water Supply in Tanzania', Water Alternatives 8.2: 57-76.

WHO/UNICEF (United Nations Children's Fund. 2010. Progress of sanitation and drinkingwater: 2010 Update. Geneva: WHO/UNICEF Joint Monitoring Programme for Water Supply and Sanitation.

WHO/UNICEF. 2012. Progress of sanitation and drinking-water: 2010 Update. Geneva: Joint Monitoring Programme for Water Supply and Sanitation (JMP).

WHO/UNICEF. 2013. Progress on sanitation and drinking water: 2013 Update. Geneva: WHO/UNICEF Joint Monitoring Programme for Water Supply and Sanitation.

World Bank, 2004. Making Services work for Poor People: World Development Report 2004, Washington: The World Bank.

World Bank, 2004. World Development Report 2004: Making Services Work for Poor People. Washington DC, World Bank / Oxford University Press.

World Economic Forum. 2013. Global Competitiveness Report 20132014.http://www.weforum.org/reports/global-competitivenessreport-2013-2014 Accessed on September 25, 2014.

Yin K.R. 2003. Case Study Research: Design and Methods (3rd Ed.).Thousand Oaks: Sage Publishers. 


\section{Annexes}

\section{Annex 1: A snapshot showing the open coding strategy used to code the interview}

materials

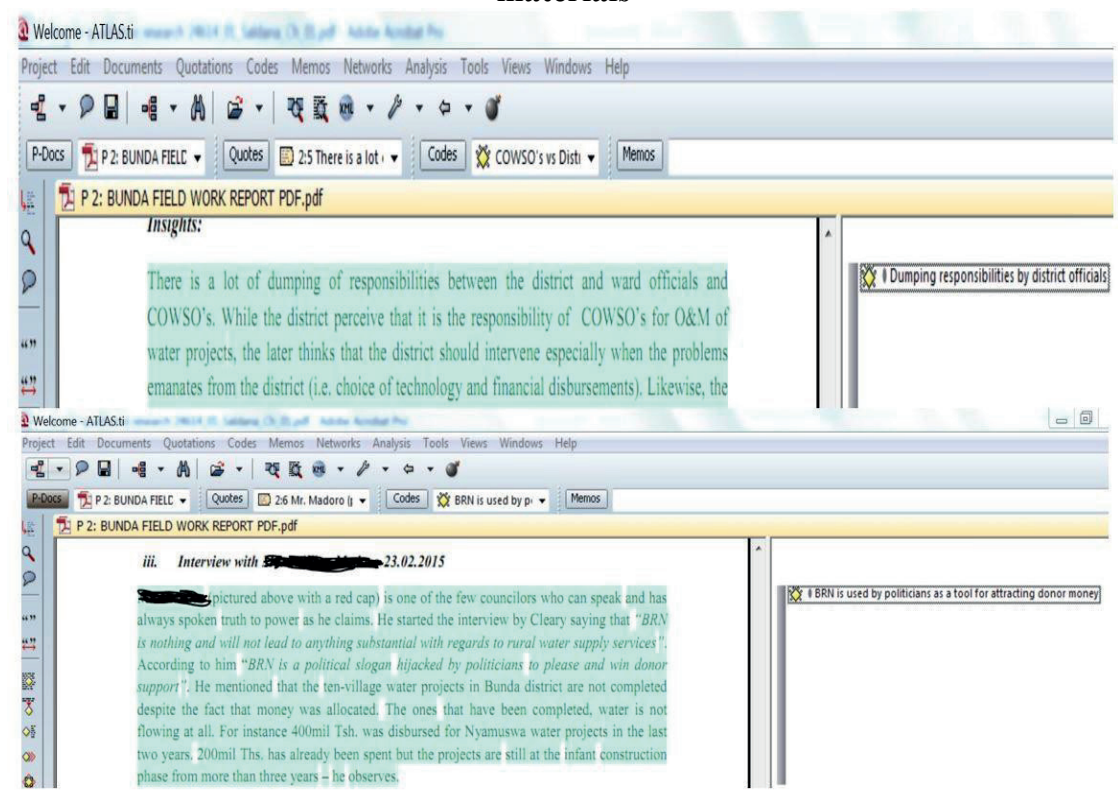


Annex 2: A snapshot showing the open coding strategy used to code some of the document materials

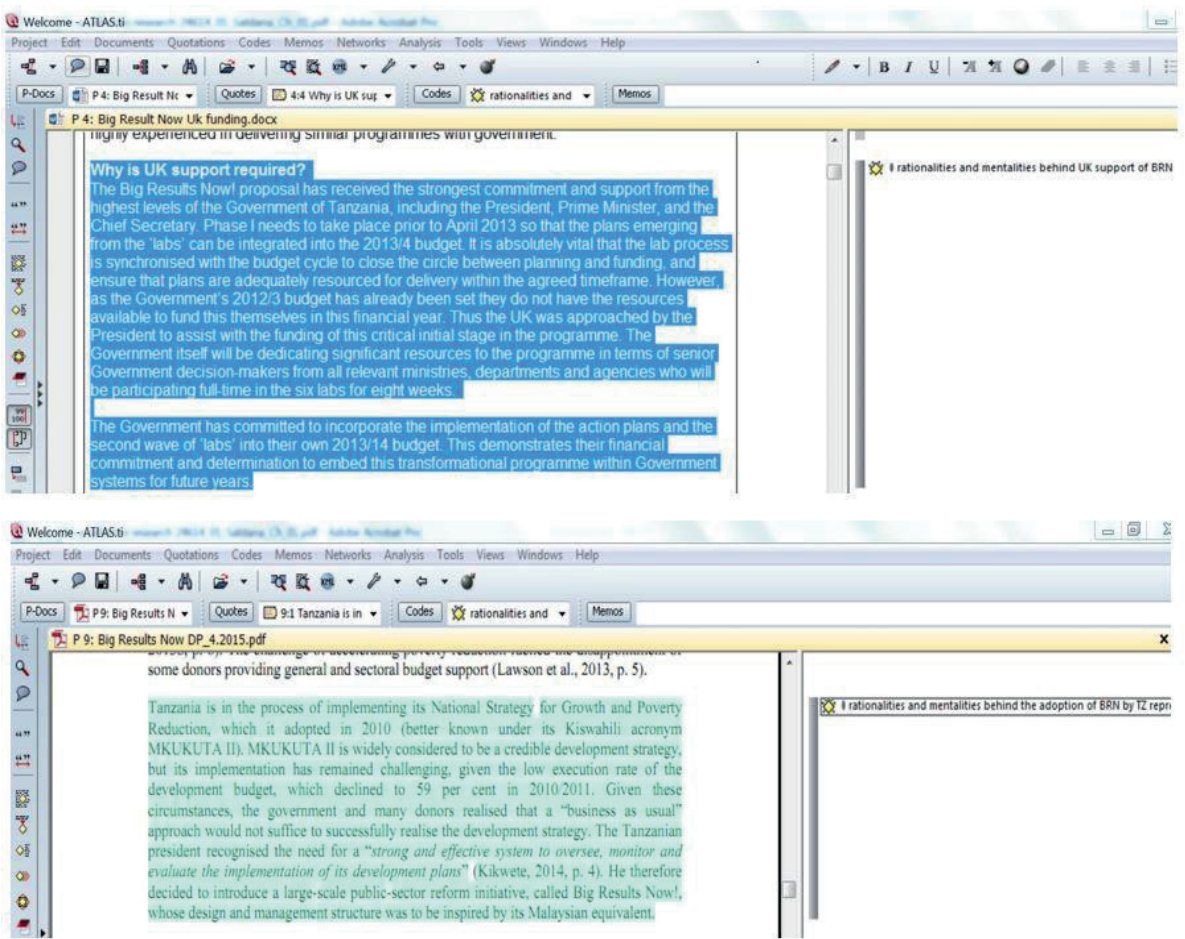


Annex 3: List of reviewed documents

\begin{tabular}{|c|c|c|c|}
\hline S/No. & Reviewed document & $\begin{array}{l}\text { Organization/ } \\
\text { institution }\end{array}$ & $\begin{array}{l}\text { Year of } \\
\text { publication }\end{array}$ \\
\hline 1 & $\begin{array}{l}\text { Water Sector Development Programme } \\
2006-2025\end{array}$ & $\begin{array}{l}\text { United Republic of } \\
\text { Tanzania (URT) }\end{array}$ & 2006 \\
\hline 2 & $\begin{array}{l}\text { Water Sector Development Programme } \\
\text { Phase II, 2014-2015/2018/2019 }\end{array}$ & URT & $2014 ; 2018$ \\
\hline 3 & The National Water policy & URT & 2002 \\
\hline 4 & $\begin{array}{l}\text { The Rural Water Supply Development } \\
\text { Programme }\end{array}$ & URT & 2010 \\
\hline 5 & $\begin{array}{l}\text { Information and Communication } \\
\text { Technology (ICT) Strategy } 2010-2014\end{array}$ & URT & 2010 \\
\hline 6 & $\begin{array}{l}\text { The National Water Sector Development } \\
\text { Strategy }\end{array}$ & URT & 2015 \\
\hline 7 & $\begin{array}{l}\text { The Water Supply and Sanitation Act, } \\
2009\end{array}$ & URT & 2009 \\
\hline 8 & $\begin{array}{l}\text { The Water Resources Management Act, } \\
2009\end{array}$ & URT & 2009 \\
\hline 9 & The Water Sector Status Report(s) & URT & $\begin{array}{r}2010,2011, \\
2012,2013, \\
2014,2015 \\
\end{array}$ \\
\hline 11 & Water Aid Annual Report 2012-2013 & URT & 2012 \\
\hline 12 & $\begin{array}{l}\text { Tanzania Rural Water Supply and } \\
\text { Sanitation Programme II }\end{array}$ & URT & 2010 \\
\hline 13 & Big Results Now Annual Report & URT & 2015 \\
\hline 14 & $\begin{array}{l}\text { Assessment Study to Identify Institutional, } \\
\text { Legal Financial Bottlenecks on Poverty - } \\
\text { Environment (P-E) Implementation at } \\
\text { Different Levels of District Ward and } \\
\text { Village in Bunda District. }\end{array}$ & $\begin{array}{l}\text { URT, } \\
\text { UNDP,UNEP,ECR } \\
\text { F }\end{array}$ & 2014 \\
\hline 15 & $\begin{array}{l}\text { Big Results Now? Emerging Lessons } \\
\text { from Results-Based Aid in Tanzania }\end{array}$ & $\begin{array}{l}\text { German } \\
\text { Development } \\
\text { Institute }\end{array}$ & 2015 \\
\hline 16 & $\begin{array}{l}\text { Business Case and Intervention Summary } \\
\text { on the Big Result Now Programme, 2013- } \\
2014\end{array}$ & $\begin{array}{l}\text { United Kingdom } \\
\text { Department for } \\
\text { International } \\
\text { Development } \\
\text { (DFID) }\end{array}$ & 2013 \\
\hline 17 & $\begin{array}{l}\text { Public Accountability in Tanzania } \\
\text { Initiative } \\
\text { Brief 1: Approach, Results \& Operational } \\
\text { Lessons, 2009-2013 }\end{array}$ & $\begin{array}{l}\text { Netherlands } \\
\text { Development } \\
\text { Organisation } \\
\text { (SNV) }\end{array}$ & 2009 \\
\hline 18 & Accountability Briefing Note & DFID & 2008 \\
\hline
\end{tabular}




\begin{tabular}{|c|c|c|c|}
\hline 19 & $\begin{array}{l}\text { Tanzania Development Assistance } \\
\text { Committee }\end{array}$ & $\begin{array}{l}\text { Organisation For } \\
\text { Economic Co- } \\
\text { Operation And } \\
\text { Development } \\
\text { (OECD) }\end{array}$ & 2003 \\
\hline 20 & $\begin{array}{l}\text { From Donorship To Ownership? Budget } \\
\text { Support and Donor Influence in Rwanda } \\
\text { And Tanzania }\end{array}$ & $\begin{array}{l}\text { Radboud } \\
\text { University } \\
\text { Nijmegen, The } \\
\text { Netherlands }\end{array}$ & 2013 \\
\hline 21 & $\begin{array}{l}\text { From Public Pipes to Private Hands: } \\
\text { Water Access and Distribution in Dar es } \\
\text { Salaam, Tanzania }\end{array}$ & $\begin{array}{l}\text { Stockholm } \\
\text { University }\end{array}$ & 2006 \\
\hline 22 & $\begin{array}{l}\text { Governance Models and Partnerships in } \\
\text { the Urban Water Sector: A Framework for } \\
\text { Analysis and Evaluation }\end{array}$ & $\begin{array}{l}\text { Tilburg University, } \\
\text { Utrecht University }\end{array}$ & 2014 \\
\hline 23 & $\begin{array}{l}\text { State weakness in Developing Countries } \\
\text { and Strategies of Institutional Reform: } \\
\text { Operational Implications for Anti- } \\
\text { Corruption Policy. A Case Study of } \\
\text { Tanzania }\end{array}$ & $\begin{array}{l}\text { DFID, University } \\
\text { of London }\end{array}$ & 2006 \\
\hline 24 & $\begin{array}{l}\text { Health through Sanitation and Water } \\
\text { Programme (HESAWA), Tanzania }\end{array}$ & $\begin{array}{l}\text { Swedish } \\
\text { International } \\
\text { Development } \\
\text { Agency (SIDA) }\end{array}$ & 2006 \\
\hline 25 & $\begin{array}{l}\text { Tanzania Human Development } \\
\text { Report: Economic Transformation for } \\
\text { Human Development }\end{array}$ & UNDP, URT & 2014 \\
\hline 26 & $\begin{array}{l}\text { ICT and Governance in East Africa: A } \\
\text { Landscape Analysis in Kenya, Uganda } \\
\text { and Tanzania } 2014\end{array}$ & iHUB & 2014 \\
\hline 27 & $\begin{array}{l}\text { Aspects of Local Self-Government: } \\
\text { Tanzania, Kenya, Namibia, South Africa, } \\
\text { Swaziland } \\
\text { And Ghana. North-South Local } \\
\text { Government } \\
\text { Co-Operation Programme }\end{array}$ & $\begin{array}{l}\text { Local and Regional } \\
\text { Government, } \\
\text { Finland }\end{array}$ & 2009 \\
\hline 28 & $\begin{array}{l}\text { The Oversight Processes of Local } \\
\text { Councils in Tanzania }\end{array}$ & $\begin{array}{l}\text { Research on } \\
\text { Poverty Alleviation } \\
\text { (REPOA) }\end{array}$ & 2008 \\
\hline 29 & $\begin{array}{l}\text { Tanzania Local Government Laws: } \\
\text { Principle Legislation }\end{array}$ & URT & 2000 \\
\hline 30 & Making Services Work for the Poor & The World Bank & 2004 \\
\hline 32 & $\begin{array}{l}\text { Understanding Patterns of Accountability } \\
\text { inTanzania }\end{array}$ & $\begin{array}{l}\text { Oxford Policy } \\
\text { Management, } \\
\text { REPOA, Chr. } \\
\text { Michelsen Institute }\end{array}$ & 2005 \\
\hline 33 & $\begin{array}{l}\text { Pay Reform and Corruption } \\
\text { in Tanzania's Public Service }\end{array}$ & President's Office & 2005 \\
\hline
\end{tabular}




\begin{tabular}{|c|c|c|c|}
\hline & & $\begin{array}{l}\text { Public Service } \\
\text { Management }\end{array}$ & \\
\hline 34 & $\begin{array}{l}\text { Pipes, Institutions and Politics: } \\
\text { Political Dynamics of the Water Sector } \\
\text { Reform in Tanzania }\end{array}$ & $\begin{array}{l}\text { Universität } \\
\text { Marburg }\end{array}$ & 2008 \\
\hline 35 & $\begin{array}{l}\text { The Political Economy of Grand } \\
\text { Corruption in Tanzania }\end{array}$ & African Affairs & 2015 \\
\hline 36 & $\begin{array}{l}\text { President's Office Public Service } \\
\text { Management } \\
\& \text { The Cabinet Secretariat, Office of the } \\
\text { Chief Secretary Strengthening the Policy } \\
\text { Development Process }\end{array}$ & URT & 2009 \\
\hline 37 & $\begin{array}{l}\text { Progress on Sanitation and Drinking } \\
\text { Water }\end{array}$ & UNICEF, WHO & 2015 \\
\hline 38 & $\begin{array}{l}\text { Structural Adjustment, Economic } \\
\text { Performance and Aid Dependency in } \\
\text { Tanzania }\end{array}$ & IMF, WB & 1993 \\
\hline 39 & $\begin{array}{l}\text { Supporting Demand-side accountability in } \\
\text { Tanzania: Is ACT helping CSO Partners } \\
\text { to Become more Effective in Achieving } \\
\text { change? }\end{array}$ & $\begin{array}{l}\text { Overseas } \\
\text { Development } \\
\text { Institute }\end{array}$ & 2011 \\
\hline 40 & $\begin{array}{l}\text { Politics and Policies in Tanzania. A } \\
\text { Comparative Study of Higher Education } \\
\text { and Land Policies. }\end{array}$ & & 2015 \\
\hline 41 & $\begin{array}{l}\text { Domestic Accountability at the Local } \\
\text { Level Inventory Study Country Report } \\
\text { Tanzania. }\end{array}$ & $\begin{array}{l}\text { African Studies } \\
\text { Centre }\end{array}$ & 2011 \\
\hline 42 & $\begin{array}{l}\text { Services and supply chains: The Role of } \\
\text { the Domestic Private Sector in Water } \\
\text { Service Delivery in Tanzania }\end{array}$ & UNDP & 2011 \\
\hline 43 & $\begin{array}{l}\text { The Accountability Function of } \\
\text { Parliament in New Democracies: } \\
\text { Tanzanian Perspectives }\end{array}$ & $\begin{array}{l}\text { Chr. Michelsen } \\
\text { Institute } \\
\text { Development } \\
\text { Studies and Human } \\
\text { Rights }\end{array}$ & 2005 \\
\hline 46 & $\begin{array}{l}\text { The Ineffectiveness of the Tanzanian } \\
\text { Accountability Framework }\end{array}$ & SIKIKA & 2011 \\
\hline 47 & $\begin{array}{l}\text { Tools of Single Party Hegemony in } \\
\text { Tanzania: } \\
\text { Evidence from Surveys and Survey } \\
\text { Experiments }\end{array}$ & WB & 2016 \\
\hline 48 & $\begin{array}{l}\text { Water Point Mapping in Tanzania: The } \\
\text { Experience of SNV Tanzania }\end{array}$ & SNV & 2010 \\
\hline 49 & $\begin{array}{l}\text { Water Aid in Tanzania: Country Strategy } \\
2011-2016\end{array}$ & Water Aid & 2011 \\
\hline 50 & Bunda District Profile & $\begin{array}{l}\text { National Board of } \\
\text { Statistics (NBS), } \\
\text { Bunda District }\end{array}$ & 2015 \\
\hline
\end{tabular}


Annex 4: List of Interviewees National, Regional and District level Interviewed Members of Parliament(MP's) of the United Republic of Tanzania-20102015

\begin{tabular}{|c|c|c|c|c|}
\hline S/No. & Institution & Constituency/Department & Position & $\begin{array}{l}\text { Interview } \\
\text { date }\end{array}$ \\
\hline \multirow[t]{25}{*}{1.} & \multirow{25}{*}{$\begin{array}{l}\text { The Parliament of } \\
\text { the United Republic } \\
\text { of Tanzania }\end{array}$} & $\begin{array}{l}\text { Kalenga Constituency, } \\
\text { Iringa }\end{array}$ & MP-Ruling party & $10-06-2015$ \\
\hline & & $\begin{array}{l}\text { Maswa West Constituency, } \\
\text { Shinyanga }\end{array}$ & $\begin{array}{l}\text { MP-Opposition } \\
\text { party }\end{array}$ & $10-06-2015$ \\
\hline & & $\begin{array}{l}\text { Muleba North } \\
\text { Constituency, Kagera }\end{array}$ & MP-Ruling party & $11-06-2015$ \\
\hline & & $\begin{array}{l}\text { Muleba South } \\
\text { Constituency, Kagera }\end{array}$ & MP-Ruling party & $11-06-2015$ \\
\hline & & $\begin{array}{l}\text { Njombe constituency, } \\
\text { Iringa }\end{array}$ & MP-Ruling party & $12-06-2015$ \\
\hline & & $\begin{array}{l}\text { Shinyanga Urban } \\
\text { Constituency }\end{array}$ & MP-Ruling party & $12-06-2015$ \\
\hline & & $\begin{array}{l}\text { Vunjo Constituency, } \\
\text { Kilimanjaro }\end{array}$ & $\begin{array}{l}\text { MP-Opposition } \\
\text { party }\end{array}$ & $13-06-2015$ \\
\hline & & $\begin{array}{l}\text { Muhambwe Constituency, } \\
\text { Kigoma }\end{array}$ & $\begin{array}{l}\text { MP-Opposition } \\
\text { party }\end{array}$ & $13-06-2015$ \\
\hline & & $\begin{array}{l}\text { Pemba South Constituency, } \\
\text { Zanzibar }\end{array}$ & $\begin{array}{l}\text { MP-Opposition } \\
\text { party }\end{array}$ & $15-06-2015$ \\
\hline & & $\begin{array}{l}\text { Kongwa Constituency, } \\
\text { Dodoma }\end{array}$ & MP-Ruling party & $15-06-2015$ \\
\hline & & $\begin{array}{l}\text { Kigoma North } \\
\text { Constituency }\end{array}$ & $\begin{array}{l}\text { MP-Opposition } \\
\text { party }\end{array}$ & $16-06-2015$ \\
\hline & & Special Seat MP, Mwanza & MP-Ruling party & $16-06-2015$ \\
\hline & & Special Seat MP, Tabora & MP-Ruling party & $16-06-2015$ \\
\hline & & Special Seat MP, Rukwa & MP-Ruling party & $17-06-2015$ \\
\hline & & Special Seat MP,Manyara & $\begin{array}{l}\text { MP-Opposition } \\
\text { party }\end{array}$ & $17-06-2015$ \\
\hline & & $\begin{array}{l}\text { Special seat MP, } \\
\text { Kilimanjaro }\end{array}$ & $\begin{array}{l}\text { MP-Opposition } \\
\text { party }\end{array}$ & $19-06-2015$ \\
\hline & & $\begin{array}{l}\text { Kasulu Urban } \\
\text { Constituency, Kigoma }\end{array}$ & $\begin{array}{l}\text { MP-Opposition } \\
\text { party }\end{array}$ & $19-06-2015$ \\
\hline & & $\begin{array}{l}\text { Kigoma South, } \\
\text { Constituency }\end{array}$ & $\begin{array}{l}\text { MP-Opposition } \\
\text { party }\end{array}$ & $22-06-2015$ \\
\hline & & Simiyu constituency & MP-Ruling party & $22-06-2015$ \\
\hline & & Morogoro Constituency & MP-Ruling party & $24-06-2015$ \\
\hline & & Singida Constituency & MP-Ruling party & $25-06-2015$ \\
\hline & & Mbeya Constituency & MP-Ruling party & $26-06-2015$ \\
\hline & & Appointed MP, Zanzibar & MP-Ruling party & $1-07-2015$ \\
\hline & & Appointed MP, DSM & MP-Ruling party & $1-07-2015$ \\
\hline & & Bunda Constituency & MP-Ruling party & $23-07-2015$ \\
\hline
\end{tabular}




\begin{tabular}{|c|c|c|c|c|}
\hline & & Mtwara constituency & MP-Ruling party & $4-07-2015$ \\
\hline & & Ruvuma constituency & MP-Ruling party & $8-07-2015$ \\
\hline & & Lindi Constituency & MP-Ruling party & $9-07-2015$ \\
\hline & & Ubungo constituency & $\begin{array}{l}\text { MP-Opposition } \\
\text { party }\end{array}$ & $13-07-2015$ \\
\hline & & $\begin{array}{l}\text { Mbozi West Constituency, } \\
\text { Mbeya }\end{array}$ & $\begin{array}{l}\text { MP-Opposition } \\
\text { party }\end{array}$ & $15-07-2015$ \\
\hline & & Iringa Urban Constituency & $\begin{array}{l}\text { MP-Opposition } \\
\text { party }\end{array}$ & $17-07-2015$ \\
\hline & & $\begin{array}{l}\text { Ludewa constituency, } \\
\text { Njombe }\end{array}$ & MP-Ruling party & $20-07-2015$ \\
\hline & & $\begin{array}{l}\text { Kilimanjaro urban } \\
\text { constituency }\end{array}$ & $\begin{array}{l}\text { MP-Opposition } \\
\text { party }\end{array}$ & $21-06-2015$ \\
\hline & & $\begin{array}{l}\text { Musoma urban } \\
\text { constituency }\end{array}$ & $\begin{array}{l}\text { MP-Opposition } \\
\text { party }\end{array}$ & $22-06-2015$ \\
\hline & & $\begin{array}{l}\text { Kinondoni urban } \\
\text { constituency }\end{array}$ & MP-Ruling party & $25-07-2015$ \\
\hline & & Moshi rural constituency & MP-Ruling party & $26-07-2015$ \\
\hline & & ublic Officials in the Minist & of Water (MoW) & \\
\hline 2. & MoW & Rural Water Supply & $\begin{array}{l}\text { Rural Water } \\
\text { Supply } \\
\text { Coordinator } \\
\text { Water Point } \\
\text { Mapping } \\
\text { coordinator }\end{array}$ & $2-04-2013$ \\
\hline & & Urban Water Supply & $\begin{array}{l}\text { Commercial } \\
\text { Monitoring } \\
\text { Engineer }\end{array}$ & 24-01-2013 \\
\hline & & $\begin{array}{l}\text { Water Resource } \\
\text { Management }\end{array}$ & Hydrologist & $25-04-2013$ \\
\hline & & $\begin{array}{l}\text { Information and } \\
\text { Communication } \\
\text { Technology (ICT) }\end{array}$ & $\begin{array}{l}\text { Statistician for } \\
\text { the IT department }\end{array}$ & 26-04-2013 \\
\hline & & $\begin{array}{l}\text { Ministerial Delivery Unit } \\
\text { (MDU) }\end{array}$ & $\begin{array}{l}\text { BRN Director } \\
\text { BRN Information } \\
\text { Expert }\end{array}$ & $\begin{array}{l}4-04-2015 \\
5-04-20154\end{array}$ \\
\hline & & $\begin{array}{l}\text { Officials responsible for } \\
\text { Water Point Mapping } \\
\text { System }\end{array}$ & $\begin{array}{l}\text { Rural water } \\
\text { supply and ICT } \\
\text { departments }\end{array}$ & $5-04-2015$ \\
\hline & EWURA & Water and Sewerage & $\begin{array}{l}\text { Principal } \\
\text { Commercial } \\
\text { Officer }\end{array}$ & $5-02-2013$ \\
\hline
\end{tabular}




\begin{tabular}{|c|c|c|c|c|}
\hline & \multicolumn{4}{|c|}{ Interviewed Public Officials in Bunda District Council } \\
\hline \multirow[t]{13}{*}{3.} & \multirow[t]{12}{*}{$\begin{array}{l}\text { Bunda District } \\
\text { Council }\end{array}$} & \multirow{4}{*}{$\begin{array}{l}\text { Senior political and } \\
\text { Administrative ranks in the } \\
\text { District }\end{array}$} & \begin{tabular}{|l|} 
District \\
Commissioner \\
\end{tabular} & 8-11-2013 \\
\hline & & & $\begin{array}{l}\text { District } \\
\text { Executive } \\
\text { Director (DED) }\end{array}$ & $11-11-2013$ \\
\hline & & & $\begin{array}{l}\text { District } \\
\text { Administrative } \\
\text { Secretary (DAS) }\end{array}$ & $11-11-2013$ \\
\hline & & & $\begin{array}{l}\text { District } \\
\text { Chairperson }\end{array}$ & 12-11-2013 \\
\hline & & \multirow[t]{4}{*}{ Rural water supply } & $\begin{array}{l}\text { District Water } \\
\text { Engineer (DWE) }\end{array}$ & 14-11-2013 \\
\hline & & & $\begin{array}{l}\text { Assistant District } \\
\text { Water Engineer }\end{array}$ & $15-11-2015$ \\
\hline & & & $\begin{array}{l}\text { Four Water } \\
\text { Technicians }\end{array}$ & \\
\hline & & & $\begin{array}{l}\text { Five members of } \\
\text { the District Water } \\
\text { and Sanitation } \\
\text { Team (DWST) }\end{array}$ & 9-04-2014 \\
\hline & & \multirow[t]{3}{*}{ Urban Water Supply } & $\begin{array}{l}\text { Executive } \\
\text { Director: Bunda } \\
\text { Urban Water } \\
\text { Supply and } \\
\text { Sanitation } \\
\text { Authority }\end{array}$ & 10-04-2014 \\
\hline & & & $\begin{array}{l}\text { Management } \\
\text { Information } \\
\text { system experts }\end{array}$ & 10-04-2014 \\
\hline & & & $\begin{array}{l}\text { District ICT } \\
\text { Manager }\end{array}$ & 13-04-2014 \\
\hline & & Planning Department & $\begin{array}{l}\text { District Planning } \\
\text { Officer }\end{array}$ & 14-04-2014 \\
\hline & & $\begin{array}{l}\text { Ward Political } \\
\text { representatives }\end{array}$ & $\begin{array}{l}\text { Councilors: } \\
\text { Nyamuswa; } \\
\text { Kalukekere; } \\
\text { Balili; Bunda } \\
\text { Urban; } \\
\text { Chitengule; Guta; } \\
\text { Unyari; Kunzugi; } \\
\text { Mcharo; } \\
\text { Nyasura;Salama; } \\
\text { Sazira; Neruma; } \\
\text { Nyamangúta }\end{array}$ & 14-04-2014 \\
\hline
\end{tabular}




\begin{tabular}{|c|c|c|c|c|}
\hline & & $\begin{array}{l}\text { Ward Administrative } \\
\text { representatives }\end{array}$ & $\begin{array}{l}\text { Ward Executive } \\
\text { Officers: } \\
\text { Nyamuswa; } \\
\text { Kalukekere; } \\
\text { Balili; Bunda } \\
\text { Urban; } \\
\text { Chitengule; Guta; } \\
\text { Unyari; Kunzugi; } \\
\text { Mcharo; } \\
\text { Nyasura; Salama; } \\
\text { Sazira; Neruma; } \\
\text { Nyamangúta }\end{array}$ & $16-04-2014$ \\
\hline & & $\begin{array}{l}\text { Village political } \\
\text { representatives }\end{array}$ & $\begin{array}{l}\text { Village } \\
\text { Chairpersons }\end{array}$ & $17-04-2014$ \\
\hline & & $\begin{array}{l}\text { Village administrative } \\
\text { representatives }\end{array}$ & $\begin{array}{l}\text { Village } \\
\text { Administrative } \\
\text { Officers }\end{array}$ & $17-04-2014$ \\
\hline \multicolumn{5}{|c|}{ Interviewed Public Officials in Mara Region } \\
\hline 4. & Mara Region & $\begin{array}{l}\text { Regional Water Engineer } \\
\text { (RWE)Regional Water } \\
\text { Advisor (RWA) } \\
\text { Regional Administrative } \\
\text { Secretary(RAS) }\end{array}$ & $\begin{array}{l}\text { Regional Water } \\
\text { Engineer (RWE) } \\
\text { Regional Water } \\
\text { Advisor (RWA) } \\
\text { Regional } \\
\text { Administrative } \\
\text { Secretary(RAS) }\end{array}$ & $\begin{array}{l}3-04-2015 \\
6-04-2015 \\
9-04-2015\end{array}$ \\
\hline 5 & DAWASCO & & $\begin{array}{l}\text { Public Relations } \\
\text { Manager }\end{array}$ & $6-02-2013$ \\
\hline 6 & $\begin{array}{l}\text { Institute of } \\
\text { Finance } \\
\text { Management } \\
(\text { IFM) }\end{array}$ & ICT & $\begin{array}{l}\text { Director of } \\
\text { Computer } \\
\text { Services }\end{array}$ & $1-02-2013$ \\
\hline 7 & $\begin{array}{l}\text { Belgian Technical } \\
\text { Cooperation } \\
\text { (BTC) }\end{array}$ & Social services & $\begin{array}{l}\text { National } \\
\text { Technical } \\
\text { Advisor }\end{array}$ & $31-01-2013$ \\
\hline 8 & $\begin{array}{l}\text { Water Aid } \\
\text { Tanzania }\end{array}$ & Policy department & $\begin{array}{l}\text { Senior Water } \\
\text { Policy Officer }\end{array}$ & $1-01-2013$ \\
\hline 9 & Telemedicine & & $\begin{array}{l}\text { Telemedicine } \\
\text { Coordinator }\end{array}$ & $7-02-2013$ \\
\hline 10 & Policy Forum & & & \\
\hline 11 & $\begin{array}{l}\text { Christian Social } \\
\text { Service } \\
\text { Commission } \\
\text { (CSSC) }\end{array}$ & $\begin{array}{l}\text { Social Service } \\
\text { Coordination Unit }\end{array}$ & $\begin{array}{l}\text { Programme } \\
\text { Officer }\end{array}$ & $22-03-2013$ \\
\hline
\end{tabular}




\begin{tabular}{|c|c|c|c|c|}
\hline 12 & $\begin{array}{l}\text { National Muslim } \\
\text { Council } \\
\text { (BAKWATA }\end{array}$ & $\begin{array}{l}\text { Social Service } \\
\text { Coordination Unit }\end{array}$ & $\begin{array}{l}\text { Coordination } \\
\text { Officer }\end{array}$ & $12-03-2013$ \\
\hline 13 & $\begin{array}{l}\text { Geo-data } \\
\text { Company }\end{array}$ & & $\begin{array}{l}\text { Managing } \\
\text { Director }\end{array}$ & $12-3-2013$ \\
\hline \multirow[t]{2}{*}{14} & \multirow[t]{2}{*}{ SNV Mwanza } & \multirow[t]{2}{*}{$\begin{array}{l}\text { Water Sanitation and } \\
\text { Hygiene }\end{array}$} & $\begin{array}{l}\text { Senior Advisor, } \\
\text { Water, Sanitation } \\
\text { and Hygiene }\end{array}$ & 18-11-2013 \\
\hline & & & $\begin{array}{l}\text { Advisor on } \\
\text { Water, Sanitation } \\
\text { and Hygiene }\end{array}$ & $18-11-2013$ \\
\hline 15 & COSTECH & $\begin{array}{l}\text { Department of } \\
\text { technology transfer }\end{array}$ & $\begin{array}{l}\text { Director of } \\
\text { Center for } \\
\text { Development and } \\
\text { Transfer of } \\
\text { Technology } \\
\text { Director of } \\
\text { Information and } \\
\text { Documentation }\end{array}$ & $25-01-2013$ \\
\hline 16 & $\begin{array}{l}\text { Commission for } \\
\text { Human Rights and } \\
\text { Good } \\
\text { Governance(CHGG) }\end{array}$ & & Legal officer & $25-01-2013$ \\
\hline
\end{tabular}




\section{Annex 5: semi-structured interview guide for chapter six and seven}

A. General questions on accountability chains between the MoW, Regions and Districts

I. Who is seeking accountability?

II. From whom (or what) is accountability sought?

III. Where (in what forums and over what extent of geographic coverage) is accountability sought?

IV. How (through what means) are the powerful held to account?

V. For what (which actions, and against which norms) is accountability being sought?

VI. Goetz and Jenkins 2005:4)

B. Specific questions on WPM system

Accountability relationships between actors involved in the WPM

I. What are the main institutional arrangements for managing WPMS?

II. Which actors ( old/new, public/private, local/international)are

involved in the management of WPM?

III. What is the relationship between these actors?

IV. How are they coordinated?

V. To whom do they render their account?

VI. In which forums do they render their accounts?

VII. How do they access WPMS information?

VIII. How do they discuss this information?

IX. Who determine the contents of the discussions and why?

$\mathrm{X}$. Which rules inform their conduct?

XI. What happens when the rules of conduct are violated?

XII. Who decides that the rules are violated?

XIII. What is the perception of these actors on digitizing rural water supply information?

1.Department of Rural Water Supply V/S the IT Department on WPMS

I. What is the relationship between officials in the department of RWS and officials in the IT department?

II. How does the department of RWS and IT department coordinate the WMPS? What are the roles of each actor?

III. How the power struggle over the control of WPMS information flow affected/ is affecting/likely to affect accountability relations?

2.Big Result Now (BRN) programme initiative

Launched in 2013, mimicking the Malaysian model of development (The Big Fast Results Initiative), BRN focuses on fast-tracking six priority areas of the economy:

i). Energy and natural gas;

(ii). Agriculture

(iii). Water;

(iv) Education;

(v). Transport; and

(vi). Mobilization of resources http:/www.pmoralg.go.tz/quick-menu/brn/

On water, the objective is to sustain water supply to $15,200,000$ people in the rural areas during a period of three years. 
I. What are the main institutional arrangements for managing BRN?

II. Which a c tors (old/new, public/private, local/international)are involved in the management of BRN?

III. What is the relationship between these actors?

IV. How are they coordinated?

V. To whom do they render their account?

VI. How do officials in the RWS and IT departments perceive the 'Big Result Now initiative'?

VII. How has BRN changed/redefined power relations between the two actors?

VIII. How has BRN redefined accountability relations in the MoW, Regions and Local Authorities?

IX. How is BRN being implemented in Mara Region and Bunda District?

$\mathrm{X}$. How is BRN perceived by district officials in Bunda District?

3. Newly created institutions involved in Managing WPMS - The President Delivery

Bureau (PDB), The Ministerial Delivery Unit (MDU), The Performance Management and Delivery Unit (PEMANDU) and the e-Governance Agency

I. How are the newly created institutions involved in the WPMS?

II. What are the main roles of these institutions?

III. How has accountability relationships changed as a result of the creation of these institutions?

IV. How has this change of relationships affected/is affecting/ likely to affect accountability relationships between new and old actors??

4. Donors and CSOs

I. How do external actors (Donors, CSO's) promote or hinder accountability in the WPMS and in which forums?

\section{SEMA Mobile Application}

II.Will public officials accept information generated by SEMA mobile app in their routine MIS?

III. Under which conditions will public officials accept information generated by SEMA mobile app?

IV. Will public officials be willing to use information generated by SEMA mobile app for improving rural water services?

V. Under which conditions will the on-going digitization of RWS information leads to more accountability and improved service delivery? 


\section{Summary}

Accountability is a politically contested notion both in its conception and actual implementation. This is because accountability touches upon almost all facets and aspects of the drive for 'democracy' and 'good governance' which have different interpretations and understandings across countries. Despite the contestation, there is a strong recurrent interest with accountability amongst scholars and practitioners in developing and developed countries alike. This interest emanates from the fact that accountability is often linked to transparency and trustworthiness. This positive framing of accountability has fuelled the drive to strengthen accountability institutions which is believed will fast-track social economic development in developing countries.

In Africa, and Tanzania in particular, international donors increasingly exert influence on governments to embrace accountability reforms as a pre-condition for receiving bilateral and multilateral development aid. This influence is noticeable in the Washington Consensus ideas about economic development and in concomitant funding programs by the World Bank, International Monitory Fund, Organisation for Economic Co-operation and Development and even Non-Governmental Organisations. This is exemplified by World Bank funded programs to improve public service delivery in Africa through the Water Sector Development Programs, Water Sector Reform Programs and the subsequent Water Policies. In this context, accountability is a key determinant in defining power relations between African countries and their western counterparts.

This study sought to answer the research question "how are public officials held to account in Tanzania in the context of water service delivery?" To answer this question, accountability practices in three levels of governance were analysed: national, regional and local, as well as the impact of trans-national arrangements on accountability practices at these levels. The study also examined the potential of enlisting ICT and mobile phone initiatives for enhancing accountability in the water sector.

The results indicate that accountability practices in the water service delivery sector in Tanzania can be understood as an interplay of different and often conflicting governmentalities where conflicting rationalities, mentalities and technologies are intertwined. This gives rise to complex and self-contradictory drivers, the result of which is that formal international donor accountability reforms are difficult to implement and can lead to counterproductive results. Thus, holding national and local level public officials to account should not be understood only through the lenses of principal-agent (PA) and collective-action (CA) theory, because these do not capture all drivers and interactions. In practice, the locally understood informal accountability governmentalities compete with the donor-driven formal accountability governmentalities.

To understand the current situation, it is imperative to consider how important elements of present accountability practices in the water sector in Tanzania have their roots in the historical governmentalities of pre-colonial, colonial, and post-independence periods. The thinking about governance (e.g. power, morality and accountability) during pre-colonial period was based in the bio-politics of agricultural and pro-creational fertility. These ideas, in turn, created a social fabric that informed the governance practices between African rulers and the rest of the society. 
Although colonialism transformed the social fabric by introducing new colonial governmentalities, it did not destroy completely the pre-colonial governmentalities. After independence the pre-colonial governmentalities re-emerged and became part of the national and local level political process. As a result, public officials, at all levels of government, practice (internal-domestic or external-transnational) extraversion games, all the while advocating for PA or CA inspired reforms. This allows them to be the winning part of a corrupt system and yet, with some credibility, say they are abolishing it, at least intentionally. Leaving the rest of Tanzania to live corruption as 'losers', as 'destiny' or an inescapable 'way of life'. At the same time, donors advocating PA or CA-inspired reforms, by default or by design, keep this system running. Only by quitting their roles do donors help abolish a perverse system and give Tanzanian citizens a chance to hold their government accountable. But this must be coupled with a mentality change among a majority of the Tanzanian people themselves in order to usher in new rationalities and technologies to eliminate extraversion. 


\section{About the author}

Jesper G. Katomero was born on 21 June, 1981 in Kigoma, Tanzania. He received his B.A degree in Political Science and Public Administration in 2007 at the University of Dar es

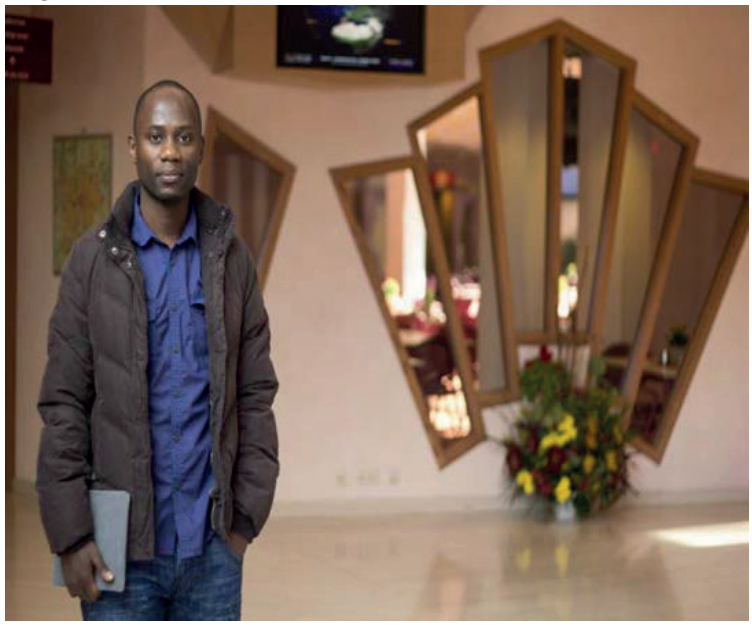
Salaam, Tanzania. In 2008, he enrolled for an M.A degree in Political Science and Public Administration at the University of Dar es Salaam, and succefully graduated in 2010 .

During his M.A studies, Jesper developed research interest in researching local government reforms which were being implemented by public officials in collaboration with international donors in Tanzania. This resulted into an M.A thesis entitled "Decentralization by Devolution Policy: Myth or Reality?" written in 2010 .

The thesis was converted into a conference paper and presented in various conferences about public sector reforms in Dar es Salaam. Since, then, Jesper became enthusiastic about the subject of reforms and public service delivery in general. A year after graduation, Jesper was recruited as an academic member of staff in the Department of Political science and Public administration as a Tutorial Assistant. Being in an academic environment as a member of academic staff, Jesper developed passion for research interests in the areas of local government, public service delivery, public policy, accountability, elections and democracy, Information and Communication Technologies (ICTs) and governance, etcetera. This resulted into some actual research works, i.e. election monitoring reports, book chapters, consultancy reports, and journal articles published in local journals.

In order to learn more, Jesper became ambitious to do a PhD. In May 2012, he successfully got a fully-funded four years scholarship, under the Sensors, Empowerment and Accountability (SEMA) research project, to study a PhD at the University of Twente in the Netherlands. SEMA was a joint research project conducted by the University of Dar es Salaam and the University of Twente. The project was funded by the Netherlands Organization for Scientific ResearchScience for Global Development (NWO-Wotro). The results of this research are presented in this thesis. Currently Jesper is employed by the University of Dar es Salaam in the Department of Political Science and Public Administration as an Assistant Lecturer. 

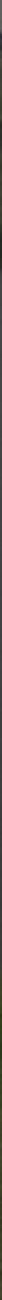